\author{
UNIVERSIDADE DE BRASÍLIA \\ INSTITUTO DE CIÊNCIAS SOCIAIS \\ DEPARTAMENTO DE SOCIOLOGIA
}

\begin{abstract}
A FORMAÇÃO DO CONSUMO GOURMET NO BRASIL:
O CASO DOS CAFÉS ESPECIAIS E DOS CORPOS QUE OS

ACOMPANHAM
\end{abstract}

Autor: Mauricio Piatti Lages

Brasília, 2015 


\author{
UNIVERSIDADE DE BRASÍLIA \\ INSTITUTO DE CIÊNCIAS SOCIAIS \\ DEPARTAMENTO DE SOCIOLOGIA
}

\title{
A FORMAÇÃO DO CONSUMO GOURMET NO BRASIL: \\ O CASO DOS CAFÉS ESPECIAIS E DOS CORPOS QUE OS ACOMPANHAM
}

Autor: Mauricio Piatti Lages

Dissertação apresentada ao Departamento de Sociologia da Universidade de Brasília como parte dos requisitos para a obtenção do título de Mestre.

Brasília, setembro de 2015 


\author{
UNIVERSIDADE DE BRASÍLIA \\ INSTITUTO DE CIÊNCIAS SOCIAIS \\ DEPARTAMENTO DE SOCIOLOGIA
}

\title{
DISSERTAC̃̃̃ DE MESTRADO
}

\author{
A FORMAÇÃO DO CONSUMO GOURMET NO BRASIL: \\ O CASO DOS CAFÉS ESPECIAIS E DOS CORPOS QUE OS \\ ACOMPANHAM
}

Autor: Mauricio Piatti Lages

Orientador: Prof. ${ }^{\circ}$ Doutor Edson Silva de Farias

Banca: Prof. ${ }^{\circ}$ Doutor Edson Silva de Farias (SOL/UnB)

Prof. ${ }^{\circ}$ Doutor Stefan Fornos Klein (SOL/UnB)

Prof. ${ }^{\text {a }}$ Doutora Fernanda Martinelli (FAC/UnB) 


\section{AGRADECIMENTOS}

À Universidade de Brasília, ao Programa de Pós-Graduação em Sociologia e à CAPES por terem subsidiado meus estudos e proporcionado todas as condições necessárias para a realização da presente pesquisa. A todos aqueles que me ajudaram, de uma forma ou de outra. Ao meu pai, pelas incursões desde cedo às aberturas sensoriais do mundo. Tenho certeza que aquelas experiências me marcaram. À minha mãe, pelo voto de confiança no jovem sociólogo, por mais esquisito que seja seu objeto de pesquisa. Aos meus amigos, claro, pela diversão e pela reflexão (já que a gente nunca separou essas duas coisas): Tiago Rodrigues, Bruno Piatti, Marcello Lavenère, Bernardo Leal, Manuela Leda, Renato Ventocilla, Thomas Amorim, Pedro Menezes, Bruno Gontyjo, Lucas Facó, Daniel Ramos, Felipe Tartas, Giovanna Vicentini, Maritza Barbosa, Lucas Benevides, e muitos outros. Aos professores Stefan Klein, Sayonara Leal, Fernanda Martinelli, Carolina Pulici e Dmitri Fernandes pelos valiosos comentários e sugestões. Ao Edson Farias, por sempre tentar extrair o melhor sociólogo de mim. Por fim, a todas as pessoas que pertencem à cadeia do café e que, graças aos seus trabalhos, tornam possível que eu tome uma xícara de café todo dia de manhã... 
"As coisas, antes de mais nada, são sagradas ou profanas, puras ou impuras, amigas ou inimigas, favoráveis ou desfavoráveis; isto é, seus caracteres fundamentais não fazem mais do que exprimir a maneira pela qual elas afetam a sensibilidade social. Diferenças e semelhanças mais afetivas que intelectuais determinam a maneira pela qual elas se agrupam. É por isso - porque afetam diferentemente os sentimentos dos grupos -, que as coisas, de certo modo, mudam de natureza, segundo as sociedades. O que aqui é concebido como perfeitamente homogêneo, adiante é representado como essencialmente heterogêneo."

Durkheim, Émile. As formas elementares da vida religiosa.

(1996, pg. 201) 


\section{RESUMO}

Nosso olhar parte da percepção de uma alteração na forma de organização do mercado brasileiro a partir da última década, especialmente no que concerne à disseminação da alta gastronomia e dos bens de luxo para parcelas ascendentes da população. Aos poucos ganha corpo um novo segmento de mercado que ficou conhecido pela oferta de produtos gourmets, na esteira de tendências internacionais de reelaboração da apresentação dos produtos. Como são transformações recentes, que começaram a se consolidar na passagem do século XX para o XXI, nossa proposta é tomar o caso do consumo de café como meio de se pensar as consequências premeditadas e nãopremeditadas desse processo de reorganização do mercado, levando em conta as implicações do mesmo para o consumidor metropolitano. Isso porque a apreciação de cafés de alta qualidade, segmento que toma parte no circuito mais amplo dos produtos gourmets, vem ganhando força nas metrópoles brasileiras, em conjunto com a disseminação massiva de cafeterias especializadas. Do ponto de vista sociológico, levanta-se a pergunta acerca dos modos socialmente estruturados de usar bens de consumo para demarcar relações sociais, já que o consumo de determinadas bebidas, como é o caso do café nas atuais metrópoles brasileiras, pressupõe uma capacitação da percepção, por parte dos consumidores, no sentido de perceber as diferenças internas à composição do produto. Assim, o consumo de café serve para apontar a existência empírica de uma nova forma de competência social, que distingue os indivíduos entre si na medida em que alguns consumidores passam a complexificar o discernimento dos produtos ofertados. Até que ponto essa nova capacitação envolve uma estratégia de distinção por parte de determinados segmentos sociais, caracterizando também novas formas de se conceber o prestígio social, é uma hipótese a ser investigada. Tendo em vista a significativa expansão desse mercado no país, pretendemos dirigir o olhar sobre a repercussão da ampliação do leque de produtos gourmets na formação de novas hierarquias simbólicas entre os consumidores, não só no sentido de uma distribuição desigual das capacidades de apreciação e usufruto dos produtos, mas também no sentido da disseminação de novas formas de conhecimento especializado - isto é, novos símbolos, novos marcadores sociais. $\mathrm{Na}$ esteira dessas inovações simbólicas, veremos também como a circulação de determinados sabores traz em evidência os conflitos sociais que se sedimentam nas cafeterias, onde consumidores e especialistas se enfrentam na antinomia das diferenças de percepção adquiridas - e onde o café amargo, forte e encorpado do brasileiro encontra o café de acidez acentuada, torra clara e dotado de notas florais e frutadas.

\section{PALAVRAS-CHAVE}

sociologia do consumo - formas de desigualdade social - formas de classificação - história social das coisas - conflitos sociais da ordem do gosto - gourmetização da sociedade 


\begin{abstract}
Our perspective begins with the perception of a significative change in the organizational form of the Brazilian market during the last decade, especially concerning the spread of the haute cuisine and the luxury goods for ascending portions of the population. Gradually, we see the emergence of a new segment that became known for offering "gourmet products", that occurs within international trends that implies re-designing the product presentation. Our proposal is to take the case of coffee consumption as a mean of studying the premeditated and non-premeditated consequences of this process, taking into account the implications for the consumers' everyday life. The appreciation of high-quality coffee, a segment which takes part in the wider circuit of gourmet products, is gaining strength in several Brazilian cities, together with the massive spread of contemporary coffeehouses. From a sociological point of view, we raise the question about socially structured ways to use consumer goods to display social distance, since the consumption of certain beverages, such as coffee nowadays, entails a sort of perceptive-knowledge capital, in order to understand the differences in the composition of the products. Therefore, coffee consumption today is empirically rich, because it shows us the existence of a new form of social competence that distinguishes individuals from one another as long as some consumers begin to sharpen their evaluation of the products offered. To what extent this new capital entails a strategy for "distinction", featuring new ways of conceiving the social prestige, that's an hypothesis that needs to be investigated. Given the huge expansion of this market, it is important to look at the results of the process towards the formation of new symbolic hierarchies among consumers, not only in the sense of an unequal distribution of perceptive skills, but also towards the spread of knowledge expertise - new symbols, new social markers. Following these symbolic innovations, it is imperative to realize that the very circulation of flavors brings about social conflicts that sediment in the coffee shops, where consumers and experts meet alongside different standards of taste - and where the bitter, strong and full-bodied Brazilian coffee confronts the bright, acidic and light-roast, endowed with floral and fruity notes.
\end{abstract}

\title{
KEYWORDS
}

sociology of consumption - forms of social inequality - forms of classification - social life of things - social conflicts on the matter of taste-gourmetization of society 


\section{SUMÁRIO}



CAPÍTULO I: A HISTÓRIA SOCIAL DO CAFÉ E DO FORMATO GOURMET .................17

CAPÍTULO II: O BARISTA COMO AGENTE DO PROCESSO DE GOURMETIZAÇÃO........65

QUESTIONÁRIO PARA BARISTAS (29 RESPONDENTES) ................................. 112

CAPÍTULO III: O CONSUMIDOR GOURMET EM CONFLITO ..........................117

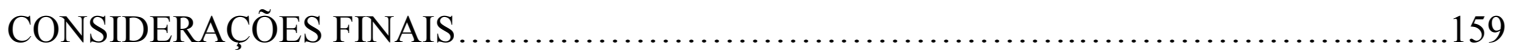








\section{LISTA DE FIGURAS}



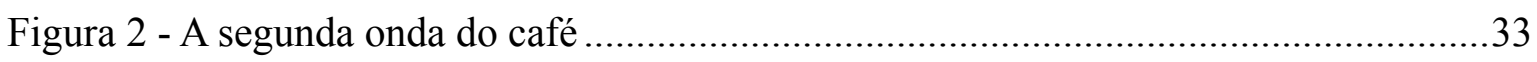



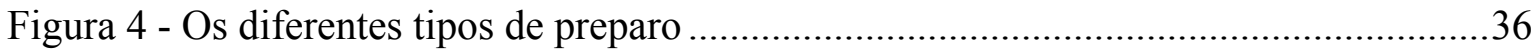

Gráfico 1 - Produção mundial de café, por região (2011/12 a 2014/15) ..............................38

Figura 5 - A bialetti e o imaginário de modernidade ..............................................................42

Figura 6 - O perfil do sabor e o selo de qualidade gourmet ..............................................59

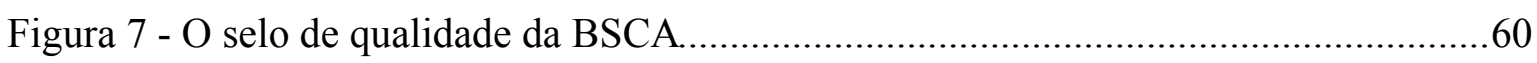

Gráfico 2 - O ranking dos maiores exportadores de café torrado, 2013 ............................61

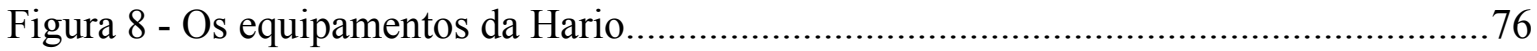



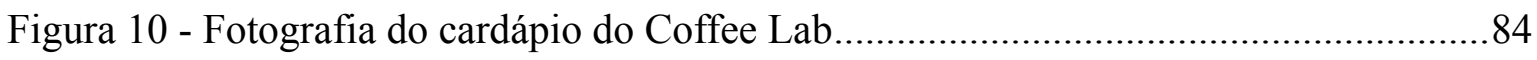

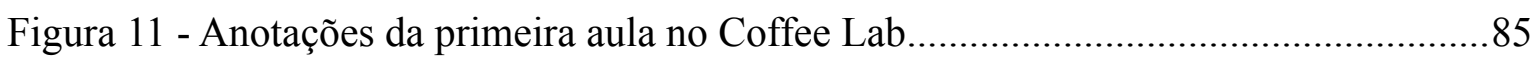

Figura 12 - Folha explicativa recebida no primeiro dia de aula .........................................85

Figura 13 - O ranking mundial de consumo de café por pessoa .......................................87

Figura 14 - Curso no Coffee Lab com o barista Renato Gutierres .....................................116

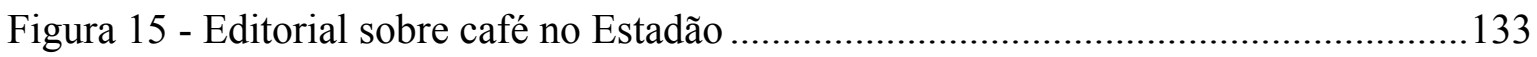

Figura 16 - Reportagem da Folha de São Paulo............................................................... 136

Figura 17 - A cafeteria Por um Punhado de Dólares no centro de São Paulo .....................137

Figura 18 - A cafeteria Beluga Café no centro de São Paulo .............................................138

Figura 19 - Esquema do conflito observado da ordem do gosto .......................................143 


\section{INTRODUÇÃO}

Minha intuição inicial era investigar a disseminação da cultura gourmet nas cafeterias. Sempre tive a impressão que o que estava diante de mim, como objeto, era muito mais próximo do consumo do que da produção. Não que essas coisas se separem, em última instância. Lembro de uma aula em que discutíamos o Grundrisse do Marx e que abordava exatamente essa questão. Os autores Heath e Meneley (2007) sintetizam do que trata aquele texto: "a produção não apenas alimenta o consumo com seu objeto, numa relação externa, e o consumo não apenas provê à produção o seu telos, mas eles também se colocam numa relação interna, como Marx argumentava. As categorias simbólicas e técnicas da produção são momentos imanentes ao consumo, e o consumo informa internamente os processos de produção" (pg. 593-594). ${ }^{1}$ Todavia, como fomos educados por muito tempo no paradigma da produção, tomando o industrialismo como modelo de desenvolvimento, o trabalho fabril, o trabalho material como forma ideal da produção de valor, isso virou um vício de pensamento. Baudrillard chama esse vício de "espelho da produção". Foi por essa razão que os primeiros estudos sociológicos do consumo tiveram que isolar a dimensão, analiticamente, para poder visualizar melhor em que medida esse suposto momento final da cadeia produtiva contribuiria, ele mesmo, para a criação do valor nas sociedades contemporâneas. Desde a segunda metade do século XX surgiram novas chaves-conceituais para lidar com esse problema, como a noção de "sociedade pósindustrial". No domínio da cultura, a questão do "pós-moderno" trouxe a tônica para a recepção cultural das obras, para a multiplicidade dos modos de apreensão das coisas, que agora passam a ser entendidas como disjunções práticas e não mais como resultados de um processo de homogeneização acachapante. Nesse sentido, o consumo como tema traz algo novo. Os temas clássicos da sociologia, como a educação, a política, a economia vista como produção, todos eles costumavam partir do caráter intencional da ação humana. Não costumamos dizer que todas as esferas foram atingidas pela chamada racionalização? Com

\footnotetext{
1 "Production not only furnishes consumption with its object, in an external relation, and consumption not only provides production with its telos, but they also stand in internal relations, as Marx remind us. Symbolic and technical categories of production are an immanent moment in consumption, and consumption internally informs the production processes."
} 
o consumo é diferente, na maior parte das vezes ele é algo que passa despercebido como plano de ação, costumamos dizer, inclusive, que ele é composto por atos impulsivos e não planejados. É possível dizer que ele lida mais com o homem como ser desejante do que como ser pensante. Esse é o primeiro pronto. Como construir um arcabouço analítico que parta do consumo como a instância formadora das necessidades humanas? É um problema difícil porque, nas ciências sociais, estamos repletos de vícios de pensamento.

Entender por quê as pessoas se tornaram obcecadas pela diferença em matéria gastronômica. Esses objetos infinitamente pequenos, o café desse ou daquele jeito, a comida preparada assim ou assado, servida desta ou daquela forma, todas essas questões iniciais se apresentaram a mim mais complexas do que se as reduzíssemos ao problema da organização racional das condutas, mesmo que se trate da organização racional do prazer de comer. É claro que quando você adentra o universo gastronômico, você percebe que existe todo um aparato de apoio, de natureza linguística, que ajuda as pessoas a perceberem as coisas de determinada forma. Existe sim, portanto, uma certa educação racional da conduta dentro do processo de gourmetização. Sem dúvidas, o aparato de linguagem é fundamental, parte da pesquisa é voltada para entender a disseminação da expertise do café através do surgimento da profissão de barista, questão que envolve o problema da especialização do conhecimento, das instâncias de disseminação desse conhecimento especializado e do surgimento de uma nova linguagem. Só que é importante lembrar que a especificidade dessa nova linguagem, veiculada pelas instâncias profissionais de preparo gastronômico, é incentivar o corpo a apreender a comida de determinada forma. E aí surge um problema: como essa linguagem incentiva o corpo? No caso do café, como isso se dá nos cursos de barista e nos próprios locais de consumo, nas cafeterias? Como a linguagem, em geral, pode incentivar o corpo? Porque a linguagem sempre foi entendida, nas ciências sociais, pela preponderância do componente verbal. Mas como o verbal, o conceitual, o "sistema de ideias e valores" de uma cultura, pode penetrar o corpo? Ora, sabemos que essa foi uma questão que motivou Foucault, por exemplo, na sua ideia de poder disciplinar. No entanto, Foucault nunca saiu da dimensão semântica da coisa e, se saiu, foi apenas em momentos isolados da sua obra, como que de relance e por um deslize da narrativa mesma. Seu objeto de análise sempre foram textos, conjuntos de textos que, quando concatenados 
normativamente, tornam-se Discurso e produzem poder. Não é de se estranhar, pois, que a parcialidade desse olhar que se debruça sobre textos se torne evidente assim que nos voltamos para as práticas de percepção. O gosto tomado como objeto sociológico. Vale lembrar que o surgimento, no Ocidente, de uma linguagem abstrata do gosto, como forma de vincular percepções não apenas conceituais mas intuitivas em relação aos objetos, teve raiz na gastronomia, na metáfora do gosto como paladar (gustibus) e que se estendeu para os outros campos da cultura. Isso quer dizer que, há quatro séculos atrás, a palavra "gosto" era exclusiva da relação com os alimentos.

Hans Ulrich Gumbrecht (2010) reclama que há um confinamento das ciências sociais à dimensão hermenêutica e interpretativa. Por exemplo, tomemos a questão do poder. O movimento analítico que vai das formas de monopolização do conhecimento humano às formas de dominação corporalmente sentidas, é um movimento unidirecional. De um modo ou de outro, ele parte da centralidade que possui, em nossa tradição epistemológica, o problema da interpretação à luz da oposição sujeito-objeto. Conhecemos bem a história. A coisa em si foi escamoteada de cena, Kant foi o juiz do processo, e o que restou foi um aprofundamento das Humanidades nas condições de possibilidade cognitiva da experiência humana: categoremas, esquemas mentais, representações, regras normativas, todos tomados como efetivos apenas porque remetem a valores, conceitos, enunciações, vozes humanas em geral. Como tudo isso chega ao corpo sempre foi uma hipótese com a qual trabalhava o pensamento e, claro, como toda hipótese, sempre foi permeada por especulações. No entanto, alguns autores foram adiante e tentaram definir programas de pesquisa que ultrapassassem a redução hermenêutica ao significado imaterial das coisas. Esse é o segundo ponto que pretendo enfatizar antes de começar. A maior dificuldade do presente trabalho, e acredito que foi o que lhe tomou mais tempo, foi tentar sustentar um programa de pesquisa focado no corpo, seguindo os passos esboçados pela sociologia de Pierre Bourdieu. Quando lidamos com o consumo de café gourmet, ou com o consumo de comida em geral, não podemos nos ater apenas às transformações da ordem do significado cultural que atribuímos a esses produtos. Se nos restringíssemos à ordem cultural, seria como se a sociologia fizesse vista grossa para o fluxo de coisas que também estão em jogo e que, de mais a mais, integram a nossa realidade histórica e circunstancial. 
É como se bastasse dizer que algo adquiriu relevância, conceitualmente, e, por um passe de mágica, uma reação em cadeia se concretizasse no mundo, desencadeando todo esse fluxo de materialidade e corporeidade. Na perspectiva culturalista, há uma antecedência da dimensão do sentido (pela via da interpretação, da tradição hermenêutica) sobre a dimensão da coisalidade do mundo: do contato próximo, quase físico, que temos com as coisas. Ora, quando trazemos de volta a dimensão do corpo e da coisa estamos lidando diretamente com a interseção entre o sentido e a matéria, entre sentido e corpo. Há possibilidades de desenvolver o instrumental analítico das ciências sociais para captar empiricamente, não apenas as transformações da ordem da atribuição de sentido, mas também transformações socio-materiais ou socio-técnicas. É o que, de alguma forma, um conjunto de antropólogos e sociólogos vem tentado fazer nas últimas décadas. Mas é também, de certa forma, o que sempre se tentou fazer, em ciências sociais, quando se falava em mediação. Walter Benjamin, por exemplo, já em 1936, afirma o seguinte:

O modo com a percepção humana se organiza - o medium no qual ocorre - não é apenas condicionado naturalmente, mas também historicamente. (BENJAMIN, 2012b, pg. 25)

À medida que fui realizando o trabalho de campo, percebi que os pequenos conflitos que eu presenciava nas cafeterias, como fica emblemático no caso do Beluga Café que eu descrevi no texto, eram conflitos não só entre ideias ou valores humanos, abstratamente pensados, essas "nuvens e almofadas de sentido", mas eram conflitos entre coisas bastante concretas: a maior ou menor presença de acidez, de amargor, o teor, a textura da bebida e a sensibilidade do paladar humano em relação a essas "coisas do mundo". Então, ficou claro, para mim, que não era um problema apenas de organização mental das coisas e, dentre as coisas, do café. Primeiro de tudo, é preciso trazer determinadas coisas para perto de si, para perto do corpo humano. Segundo, é preciso treinar a percepção dessas coisas. Nos espaços pesquisados, isto é uma questão imanente: os sentidos estão sendo articulados de determinada forma, não apenas significados (como matéria inerte, receptáculo de cultura), mas manejados, construídos, e isso acaba por criar disposições gerais que são compartilhadas por um número maior de pessoas. É o que eu chamo de socialização pelo mercado. Resolvi aplicar os questionários para tentar mapear 
como as pessoas se vêem nesse processo, se há ou não realmente um processo de mudança: a hipótese de uma socialização sensória. Claro que a própria natureza de questionário nos limita porque se reduz ao que é exprimível verbalmente. Mas o intuito foi construir uma ferramenta de contraste à observação etnográfica. A ideia, tanto da parte etnográfica quanto dos questionários, era tentar extrair o que muda quando o sujeito entra no universo de mercado das cafeterias gourmets, se algum padrão de gosto prevalece, se há uma capacidade formal (de perceber os sabores) que é desenvolvida, etc. Diante desse propósito, as perguntas do questionário foram formuladas mais nesta direção: que sabores circulam nesses espaços e como eles são absorvidos pelos funcionários e pelos consumidores? A partir daí eu procuraria entender como esses sabores estão definindo novas preferências, se esses sabores constituem emblemas de distinção, o que pertence à dimensão normativa do espaço social. Acredito que apenas em situações de conflito nós percebemos mais nitidamente o caráter social da percepção humana, ou melhor, a ideia de que ela requer uma aprendizagem social. David Howes elabora esse tópico num artigo que leva o nome "a vida social dos sentidos":

Nós somos conscientes do que percebemos (os objetos de percepção), mas raramente tomamos conhecimento de como percebemos. A percepção é, no entanto, uma competência, apesar do fato de parecer brotar naturalmente. Por exemplo, pode parecer que a fim de ver, tudo o que se precisa fazer é abrir os olhos; no entanto, o homem cego cuja visão é restaurada não é capaz, no primeiro momento, de reconhecer as formas que ele conhecia através do toque, ele precisa aprender a coordenar as suas impressões sensoriais, o que mostra o quanto a percepção requer prática. Se a percepção requer prática, então ela é uma habilidade, e onde tem habilidade tem cultura, e onde tem cultura também tem história. (HOWES, 2013, p. 14)

Quando fiz o curso de barista, fui treinado a perceber determinadas características sensoriais que não estava habituado a notar. A linguagem desempenhou seu papel e fui ensinado naquilo que o café poderia trazer: "Aroma, sabor, acidez, corpo, doçura, sabor residual, defeitos, amargor, adstringência" (nove características). Aprender teoricamente o que significava esses conceitos não era suficiente. $\mathrm{O}$ mais importante era testar, contrapor diferentes produtos para tentar extrair o diferencial, prática que é chamada de "degustação". Até porque muitos desses parâmetros nós já tínhamos referências no cotidiano. Limão é ácido, chocolate é doce, vinho é adstringente, jiló é amargo, e assim por 
diante. Coordenar esses referentes e aplicá-los em um único produto constituía a novidade do curso para nós aprendizes. Certamente, as preferências pessoais também entram em jogo sob a forma de hábitos de consumo arraigados. Tem gente que não gosta de amargo, tem gente que só toma algo ácido com açúcar, tem gente que ama doce, etc. Só que quanto mais entramos nesse universo das cafeterias especializadas ou no universo da degustação em geral, mais percebe-se que existe um esforço gigantesco de reeducação sensória. Mesmo que um sabor não agrade de primeira, pela sua memória afetiva, o sujeito passa a apreciar o próprio ato de reconhecer sensorialmente o sabor, de identificá-lo, ou seja, de dar existência para as características materiais do produto e de ativar o corpo nas novas direções. Entender esse processo não como uma experiência pessoal mas como uma forma de experiência social em expansão é a tarefa que se coloca na presente pesquisa.

Essas transformações não dizem respeito apenas ao modo de tematizar o mundo, de inserir estruturas narrativas ou de colocar em quadro novas formas de orientação da conduta. Elas dizem respeito a novas formas de sentir, novas formas de sentir o próprio corpo fisicamente. Em termos históricos, o surgimento de novas formas de sentir entra em contraste com as formas de sentir anteriores. Esse era o tema de Walter Benjamin n'A obra de arte na era de sua reprodutibilidade técnica, obra na qual Benjamin diagnosticava uma transformação do sensório humano mediada pelos novos aparatos técnicos, em especial pela replicagem de imagens em larga escala. E assim como uma nova forma de visão só passou a existir pelo contato contínuo dos olhos humanos com a tela do cinema, com a fotografia impressa nos jornais, o que percebemos hoje como transformação sensória no mercado gastronômico, em termos amplos, só pode existir pela mediação com as coisas, com essas novas materialidades que estão sendo trazidas para perto do corpo. Não vamos nos enganar. $\mathrm{O}$ corpo não projeta para fora de si visões que a consciência absorveu em aprendizagens meramente conceituais. Ao contrário, o corpo é estimulado pelo mundo desde sempre. Ele aprendeu a conceituar o mundo apenas quando ele aprendeu a sentir as coisas e a coordenar as percepções sensoriais. Esse vínculo genético permanece operante por mais que se avance adiante nas ilusões da civilização ocidental. Aquilo que chamamos de "estrutura social", essa complexa dependência mútua entre os homens divididos em diferentes funções, também contribui para moldar as coisas com as quais os corpos irão 
dialogar nas próximas gerações, nas próximas gerações de pedagogia sensória. De um lado, o corpo é capacitado pela cultura subjetiva formulável e canalizável; aí está a educação como projeto, o conhecimento entendido na sua faceta de abstração conceitual. De outro lado, o corpo é estimulado pela cultura objetiva do mundo: ele aprende quando traz para perto de si determinados objetos, utensílios, instrumentos, telas, substâncias, coisas.

A ideia da pesquisa é contextualizar o surgimento das cafeterias modernas, "modernas" porque a nosso ver elas possuem essa função simbólica de expressar um estilo de comportamento afim a ideais de modernidade e requinte, por terem compromisso com o "novo". Nessa perspectiva, o café não é apenas substância-café mas um signo ligado a atitudes humanas tipificadas, ou seja, a protocolos e estilos de vida que extrapolam o domínio concreto da alimentação. Como colocaremos no capítulo um, é possível relacionar a popularização do consumo de café espresso, na Itália, com o ideal fascista de progresso e velocidade. A realidade alimentar se engrandece através da imagem e do signo históricos. Isso é importante. No entanto, se quisermos entender os efeitos do novo estilo de vida sobre os novos contingentes de consumidores, essa abordagem que apela para a semiótica dos estilos de vida nos parece insuficiente, pois é preciso entender a profundidade da aproximação infinita das coisas ao corpo que as engole: esse corpo experimental do ponto de vista gastronômico. Caso contrário não entendemos a especificidade da conduta gastronômica no mundo. Claro que não posso abrir mão do arcabouço da significação. Não há como fazer ciências sociais sem apelar para esse plano que isola o animal humano, coloca-o à parte das coisas para depois indagar a maneira em que ele traça um caminho significativo no mundo, ou seja, a maneira em que o mundo lhe repercute enquanto escolha, enquanto marca de decisão humana, como sentido. Mas isso permanece insuficiente.

Ao invés de tentar identificar o sentido imaterial oculto por trás da superfície de um significante material, nós devíamos dirigir o olhar sociológico para o impacto dos objetos sobre os corpos humanos. Gumbrecht chama isso de produção da presença, que ele contrapõe à produção do sentido. A superfície que nos toca e nos instiga a sentir. Só a partir de uma perspectiva que leve em conta as superfícies dispersas no mundo é que 
descobrimos que existem conflitos que não são de ordem ideacional. Existem conflitos sociais que vem do tato, do olfato, do paladar, do senso em geral. Entender esses acontecimentos como problemas sociais: como se distribui historicamente o sentir e o não sentir? Acostumar-se a sentir determinadas coisas, não senti-las, ser indiferente a elas. Chamar isso de "social" é dizer que existem mudanças que atingem periodicamente conjuntos de pessoas, que existem padrões gerais envolvidos e modulações recíprocas. E esses padrões são provocados também pelas coisas que estão ali, à nossa volta. Coisas que podem ser aproximadas ou distanciadas. Disseminadas ou monopolizadas. Coisas. Tal como o "café forte" que o cliente tentou conseguir na cafeteria Beluga, para logo decepcionar-se e descobrir que as coisas ali são outras, e essas coisas, esses "cafés ácidos e diluídos" preparados por esses baristas jovens e tattooados, estão ali também para apontar a existência de outros modos de sentir humanos, outros tipos de ser social. Quem se sente inferior ou superior nesses contextos? Que conjunto de coisas o conhecimento especializado traz consigo? Há como produzir conhecimento sem um meio no qual ele se realize? Existe prestígio apenas na dimensão do sentido e, forçosamente, fora do mundo das coisas? Ou o senso de dignidade social só existe quando mediado pelas coisas, técnicas, aparatos, conceitos (inclusive), mas conceitos junto com coisas, com matérias, espadas, togas, microfones e câmeras? Voltar para o problema do simbólico, hoje, é desestabilizar o domínio do significado. Em vez de perguntar "o que o café significa?", “será que beber café ainda é moderno?", talvez fosse melhor perguntar: como ele simboliza? Por que o trazemos para perto de nós? E, talvez mais importante, o que esse trazer para perto implica? 


\section{CAPÍTULO I}

\section{A HISTÓRIA SOCIAL DO CAFÉ E DO FORMATO GOURMET}

Tomar a história da alimentação ou dos objetos tecnológicos à nossa volta deveria ser um exercício mais recorrente nas ciências sociais, afinal, diz respeito a problemas que atingem a estrutura mesma do cotidiano. No entanto, sabemos que a historiografia voltada para o cotidiano é algo muito recente na história das ciências humanas. Sua principal força propulsora foi a Escola dos Anais, um grupo liderado inicialmente por Lucien Febvre e Marc Bloch, em proximidade com Henri Pirenne, Albert Demangeon, Lévy-Bruhl e Maurice Halbwachs, e que depois contou com outras gerações de intelectuais, como Fernand Braudel, Jacques Le Goff e Philippe Ariès. Posteriormente, a unidade do legado desses autores acabou sendo reconhecida como um dos principais movimentos teóricos do século XX. Esses pesquisadores, em sua maioria franceses, se juntaram em torno de uma revista recém criada, os Annales, para se contrapor à historiografia que prevalecia desde o século XIX, voltada fundamentalmente para a façanha dos grandes homens, dos grandes inventores e que, por essa razão, ficou conhecida pela alcunha de "história diplomática". Já a "nova história", como foram denominados os desdobramentos do grupo dos Annales, parte de uma ideia bastante simples: é preciso estudar como os homens viviam de fato em seu cotidiano, o que comiam, como rezavam, como trabalhavam, como se vestiam, como se comportavam diante dos outros, como amavam, e assim por diante. Nosso trabalho é inspirado por esse movimento de ideias, na medida em que procura desvendar as tramas de uma convivência rotineira com o café que vem ganhando corpo no Brasil contemporâneo. Acerca do estilo de pensamento que se estabeleceu com essa tradição historiográfica, Philippe Ariès comenta o seguinte:

Todos esses autores, quer tenham pertencido ao grupo dos Annales, quer fossem estranhos ou marginais a ele, reconhecem que pertence à história um outro domínio diferente daquele em que até então ela fora limitada, que era unicamente o das atividades conscientes, voluntárias, orientadas para a decisão política, a propagação das ideias, a conduta dos homens e dos acontecimentos. [...] Os historiadores falam em "estrutura mental", em "visão de mundo", para designar os traços coerentes e rigorosos de uma totalidade psíquica que se impõe aos contemporâneos sem que eles saibam. Talvez os homens de hoje experimentem a necessidade de fazer emergir até a superfície da consciência os sentimentos outrora sepultados numa memória 
coletiva profunda. Busca subterrânea das sabedorias anônimas: não uma sabedoria ou verdade intemporal, mas, sim, sabedorias empíricas que regulam as relações familiares das coletividades humanas com cada indivíduo, com a natureza, a vida, a morte, Deus e o além. (ARIÈS, 2011, p. 272 e 295)

Nesse ponto, interessa-nos a tônica que esses autores colocaram na noção de inconsciente, pois abre-se mão do linguajar voluntarista e cognitivista que marcou o antigo método histórico e que continua a marcar as ciências sociais dos dias de hoje. Le Goff complementa:

O historiador das mentalidades aproximar-se-á, pois, do etnólogo, visando a alcançar, como ele, o nível mais estável, mais imóvel das sociedades. [...] O nível da história das mentalidades é aquele do quotidiano e do automático, é o que escapa aos sujeitos particulares da história, porque revelador do conteúdo impessoal de seu pensamento, é o que César e o último soldado de suas legiões, São Luís e o camponês de seus domínios, Cristóvão Colombo e o marinheiro de suas caravelas têm em comum. (LE GOFF, 1995, pg. 69 e $71)^{2}$

No entanto, por mais lentas que sejam as mudanças na ordem do inconsciente - e Le Goff chega a falar da história das mentalidades como "história da lentidão na história” (1995, pg. 72) -, as mudanças acontecem. Cabe ao historiador atento ao tempo presente, ou ao sociólogo, esse "historiador do presente", investigar a direção que vem tomando a maneira de pensar e de sentir de um povo. No entanto, aqui cabe uma ressalva, pois a fala de Le Goff faz referência a uma unidade total de mentalidade compartilhada por César e por seus soldados. Já a sociologia torna possível pensar também as disjunções mentais provocadas pelo conflito entre grupos sociais distintos. A hipótese da totalidade mental de um povo ou de uma época é apenas uma preocupação secundária - no menor dos casos, desconfia-se dela. Para nós, mais importante é o problema da relacionalidade do

2 É importante lembrar que a noção de "mentalidade" acionada pelos autores da Escola dos Anais não é sinônimo do que entendemos por "mental" em sentido mais comum, como algo cognitivo e consciente. A tradução dificulta. Mas a esse ponto, Le Goff (1995) é bastante claro: o termo "mentalité" (substantivo em francês, meados do século XIX) não é o mesmo que "mental" (adjetivo do latim mens, meados do século XIV), pois o substantivo corresponde a outras necessidades que o adjetivo. O substantivo pode ser visto como um prolongamento do inglês mind: designa a coloração coletiva do psiquismo, a maneira de pensar e de sentir de um povo, ou de um certo grupo de pessoas. Também ligado ao termo alemão Weltanschauung: visão de mundo, de tudo um pouco, "um universo mental ao mesmo tempo esteriotipado e caótico" (Idem, pg. 73). Portanto, "mentalidade" não tem nada a ver com deliberação consciente, até porque a maioria dos autores da Escola dos Anais estava interessada no domínio do imaginário, do sentimento e da gratuidade, muito mais do que no domínio da racionalidade econômica ou política. 
poder, isto é, o problema da repartição e do manejo de recursos historicamente acumulados, historicamente desiguais. Aqui, por exemplo, o refinamento dos costumes entra em jogo no modelo, na medida em que ele expressa, empiricamente, a necessidade que as pessoas possuem de re-estabelecer a diferença social - via performatização da diferença inicial diante de recursos escassos (aquilo que diz respeito à economia). A própria visão do mundo social que os agentes possuem em suas práticas cotidianas só pode ser tomada, pelo analista, como sendo de caráter fragmentário. Ela é multiplicada tão logo muda-se o prisma pelo qual se olha o "todo", e assim a suposta mentalidade compartilhada desmorona. Acredito que essa ressalva faça parte da própria natureza do método etnográfico em ciências sociais, por isso evitaremos o termo "mentalidade", a fim de evitar implicar uma ideia de totalidade empírica.

A nosso ver, esse conjunto de autores trilharam um caminho para o estudo dos fenômenos de ordem inconsciente e que possuem maior persistência nas sociedades. A alimentação é uma dessas facetas arraigadas do comportamento humano, na medida em que envolve não apenas a questão das preferências alimentares compartilhadas por uma dada população, mas também a questão das técnicas culinárias que, por sua vez, ajudam a dar a forma final aos alimentos, transformando-os em comida e, por assim dizer, em cultura. Nosso objeto de estudo, o café, é uma bebida que também é marcada por essa conjunção entre gosto e técnica. O gosto, como conjunto de disposições que revelam a afinidade intuitiva das pessoas com as coisas, é composto, dentre outras características, pelos sabores/sensações que são apreciados na comida (salgado, doce, amargo, azedo; gorduroso ou saudável; rústico ou refinado; etc.). A técnica envolve, principalmente, a questão dos modos de cocção do alimento (refogado, cozido, frito, tostado, cru, assado, etc.) e dos modos de preparo da bebida (no caso do café: coado, espresso, etc.), além das formas de apresentação (petisco, refeição, banquete) e de degustação (gire o copo assim, cheire antes de engolir, espere esfriar; etc.). A noção de "hábitos alimentares" condensa essas várias dimensões. Neste capítulo, procuraremos passar um pouco pela história dos hábitos de tomar café, desde sua origem até o momento contemporâneo, que é marcado pela segmentação de mercado e no qual o gourmet é tido como sinônimo de qualidade. Os hábitos alimentares de um determinado local e período dizem muito a respeito das 
conexões que estão feitas a nível global, envolvendo matérias-primas, produtos industrializados, recursos tecnológicos, modelos culturais, modalidades de trabalho e formas de conhecimento, conexões que tornam possível a experiência imediata do ato de consumo - em sua praticidade não racionalizável. Todos esses nódulos dizem respeito a uma orquestração social ampla do ato da alimentação, o que possibilita que produtos de vários lugares do planeta sejam acessíveis para o consumo diário a custos relativamente baixos.

No que diz respeito às refeições fora de casa, houve um desenvolvimento sem precedentes possibilitado pelas formas de convivência da modernidade europeia, alterando os hábitos alimentares. Antes do final do século XVIII, na França, as refeições fora de casa basicamente se restringiam às estalagens destinadas aos viajantes e comerciantes em trânsito. Não havia cozinha de rua de luxo. A própria palavra "restaurante" surgiu como alusão a esse contexto das estalagens nas estradas, local onde as pessoas repousam e "restauram" suas forças comendo e bebendo. O primeiro restaurante tal como conhecemos foi o Grande Taverne de Londres, criado em 1782, em Paris. A Revolução Francesa ajudou a disseminar essa cultura dos restaurateurs, na medida em que, ao destituir a aristocracia, deixou desempregado um enorme contingente de serviçais hábeis no trato com os alimentos. A alta cozinha abandona a corte e vai para as ruas de Paris. Daí em diante, dissemina-se a arte de comer bem fora de casa. Os cafés também se proliferam nessa onda dos estabelecimentos refinados de gastronomia. Juntos, os cafés e os restaurantes opõem-se às tabernas, estabelecimentos que vendiam bebidas alcóolicas e que também vendiam alguns pratos de comida, mas que tinham uma "convivialidade barulhenta". Segundo as palavras de Pitte:

Para beber e encontrar os amigos num espaço requintado deve-se ir ao café, um gênero de estabelecimento cuja origem remonta ao século precedente [XVII]. Foi em 1674 que o napolitano Francesco Capelli, dito "Procope", abriu o primeiro café em Paris, na rue de Tournon. Em 1684 este foi transferido para a rue de 'Ancienne-Comédie', local onde atualmente existe um restaurante que mantém a mesma denominação. Em pouco tempo, de Veneza a Viena, passando por São Petersburgo, Londres e Paris, os cafés tornaram-se espaços onde sopra o espírito, pelos menos o das Luzes. Neles, servem-se também chá e chocolate - bebidas exóticas acompanhadas de bolos e sorvetes. (PITTE, 1998, pg. 753) 
Restaurantes, bares, coffeehouses, cafés, toda a sorte de estabelecimentos voltados ao culto do prazer gastronômico foram se desenvolvendo na Europa ocidental. Enquanto isso, do outro lado do Atlântico, crescia uma nova disciplina alimentar como reação da classe média contra a opulência que marcava os Estados Unidos do século XIX. A superabundância dos alimentos, em especial a carne, levou congressistas como W. S. Graham a adotarem o vegetarianismo e a farinha integral, bem como o preceito de 'comer menos' de tudo o que fosse comestível. Segundo Levenstein (1998), estabeleceu-se uma afinidade eletiva entre as necessidades da classe média e os reformadores protestantes, isto porque a nova dietética (leia-se hábito alimentar preocupado com a saúde) se coaduna muito bem com a abnegação puritana: ambas procuram evitar ao máximo os excessos do corpo. Nas classes superiores, por outro lado, o preceito da abnegação não mobilizava muitos adeptos, já que a própria riqueza extrapolava-se em jantares solenes e recepções à francesa. No entanto, o segmento da gastronomia puritana prosperou em alguns círculos da classe média e teve efeitos profundos no século XX. Mais ou menos nos anos 1920 surgiu um novo modelo de alimentação elaborado em torno das vitaminas, que passavam a ser associadas à vitalidade, ao vigor e ao tônus do corpo humano saudável. Para nossa pesquisa, esse movimento de diminuição da valorização da gula em círculos abastados é um grande exemplo da complexidade que possui a questão da alimentação associada à estrutura social de um país. Seguindo essa tendência, o consumo de leite aumentou consideravelmente nos anos 1920 e 1930, já que as estratégias de marketing modificaram a imagem do leite, que agora era enlatado “com adição de vitamina D”! 3 Um bom índice da mudança que essas estratégias desempenharam nos consumidores é a preferência dos soldados no período da guerra. Enquanto que para os soldados da Primeira Guerra o café era a bebida favorita no campo de batalha, para os soldados da Segunda Guerra o favorito

3 Isto é uma simplificação do processo. Na verdade, as empresas de laticínios (dairies) começaram a adicionar vitamina D nos anos 1920 não apenas por razões publicitárias, mas também devido à disseminação do raquitismo no período, uma doença óssea causada justamente pela deficiência de vitamina D (WILEY, 2007). Além disso, a vitamina D aumenta a absorção de cálcio, que é um componente essencial do leite. Em termos gerais, no entanto, é possível falar que a descoberta das vitaminas e dos minerais nos anos 1920 foram fundamentais para as subsequentes estratégias de marketing da indústria alimentar nas próximas décadas (LEVENSTEIN, 1988). O leite desnatado, junto com as outras formas de redução de gordura derivadas do leite, apresenta uma quantidade substancialmente menor de vitamina A, portanto, também ela passou a ser adicionada a esses produtos (WILEY, 2007). O caso do leite é um exemplo interessante das mudanças materiais pelas quais passam os produtos que sofrem a intervenção da tecnociência. 
passou a ser o leite fresco.

Nos anos 1950, os Estados Unidos experimentou uma verdadeira revolução nas técnicas de conservação e embalagem dos alimentos. Só entre 1949-1959, por exemplo, os profissionais químicos da indústria apresentaram mais de 400 novos aditivos químicos, usados basicamente para melhorar os aspectos do alimento enlatado. ${ }^{4}$ A partir daí, a estética da saúde e o prazer gastronômico dos alimentos cederam lugar a um terceiro determinante: a "comodidade". Junto com os alimentos enlatados, a industrialização da comida trouxe os "pronto-a-servir", os aparelhos eletrodomésticos e, claro, os supermercados! Marcas de um tempo novo, um tempo voltado para o aspecto prático das coisas. Foi nesse momento que houve um crescimento, entre os anos 1946-1963, da família americana, em virtude da melhoria das condições de vida no lar. A elevação das taxas de natalidade ficou conhecida pela mídia como o fenômeno do Baby boom. Nascia a sociedade industrial de consumo. No final dos anos 60 , houve um movimento de crítica aos tratamentos industriais dos alimentos que, segundo se pensava, estava em conivência com o "complexo militar-industrial" da Guerra do Vietnã. Como consequência, houve um retorno ao espírito puritano do século XIX, mistura de saúde, moralidade e romantismo. Rapidamente, viraram moda os alimentos biológicos e naturais - a contraparte material do novo misticismo oriental que ganhava adeptos crescentes nas classes médias e altas americanas. Em termos abrangentes, Levenstein (1998) caracteriza essa nova fase da transformação dos costumes alimentares americanos como sendo a fase da negative nutrition, pois enfatizava não o que a comida tinha de bom, mas aquilo que ela não tinha de ruim: baixa calorias, sem colesterol, sem sal, $0 \%$ de gordura, etc. Foi uma verdadeira reorganização do mercado como um todo, que gerou efeitos extremos até os dias de hoje.

Para Fischler (1998), também foram os anos 60 que instauraram a sociedade hedonista americana, aquilo que resultou na sua contra-afirmação hippie; no entanto, o autor afirma que na Europa essa reorganização do mercado teve que esperar um pouco mais para acontecer. Os fast-foods, por exemplo, que se difundiram nos Estados Unidos durante os anos 1950 ao longo dos eixos rodoviários, nas periferias das grandes cidades,

4 Nos anos 1960 foi a vez das embalagens plásticas, no lugar dos enlatados, e das garrafas de PVC (Cf. FISCHLER, 1998). 
nos centros comerciais e nos malls, só chegaram na Europa de fato nos anos 1980. No que diz respeito aos produtos de supermercado, a tendência foi tal que o trabalho culinário se deslocou cada vez mais da cozinha para a fábrica, tanto nos restaurantes quanto em casa (FISCHLER, 1998, pg. 847). Aos poucos, portanto, foi-se formando um complexo eixo de produção voltada para o consumo de massa, uma verdadeira indústria agro-alimentar agro na medida em que a produção de laticínios e de commodities constituía uma grande parcela dos insumos do produto final. Essa reorganização teve efeitos imediatos no consumidor, segundo as palavras de Fischler:

\begin{abstract}
Alguns consumidores começam a se queixar: seu queijo favorito é, quase sempre, pasteurizado, as maçãs são apenas da variedade insípida dita Golden delicious, as frutas chegam ao supermercado sem o grau devido de maturação, o pão já não tem as características gustativas às quais estavam acostumados. Em contrapartida, os supermercados oferecem preços vantajosos ao conseguirem consideráveis economias pelas compras em alta escala. (FISCHLER, 1998, pg. 847)
\end{abstract}

Apesar da persistência da tendência anti-utilitarista que nos foi legada pelo movimento hippie dos anos 1960 e 1970 em matéria de alimentação, os anos 80 voltaram atrás com o advento dos Yuppies. Oriundos de segmentos sociais ascendentes, os Yuppies eram marcados pela busca de distinção social - uma espécie de retorno ao "colarinho branco". Enquanto o movimento hippie pregava a viagem interior como movimento de espiritualização do eu, os Yuppies eram, nesse sentido, pós-hippies, pois aceitavam muito bem o fato de viverem em uma sociedade de mercado. Eles não apenas aceitavam o "consumo conspícuo", mas se vangloriavam da lógica mercantil - em termos morais, as pessoas do período passaram deliberadamente a julgar as outras pessoas pelo gosto e pelos hábitos de consumo. Ora, o consumo gourmet, tal como o entendemos, é produto desse período. Segundo Fischler (1998), depois do período de industrialização da alimentação segue um período de "segmentação" dos mercados, isto é, cada vez mais voltados para nichos de consumidores. Para nós, o circuito gourmet funciona como um nicho de consumo que procura se contrapor, de um lado, a algumas tendências dessa industrialização gastronômica que acabamos de narrar e, de outro, busca reformular o modelo do produto industrial, no sentido de fornecer uma maior gama de variedade 
sensorial para o consumidor - a chamada "experiência" de apreciação do produto. ${ }^{5}$ Como o gourmet preza pela complexidade do prazer gastronômico, em certo sentido há um retorno à lógica europeia, especialmente à francesa, àquela que elevou a culinária ao título de arte e que, naquele movimento, perdoou e sacralizou a Gula. Parece-nos que os Estados Unidos legou o relaxamento das etiquetas e das maneiras de estar à mesa, em relação à gastronomia europeia - especialmente à francesa, que serviu de modelo de refinamento. Não seria de todo tolo dizer que as refeições servidas em bandejas dos fast-foods, a qualquer horário do dia, junto com a facilidade dos alimentos prontos de supermercado ajudaram a criar uma nova pedagogia da organização do corpo, própria às sociedades contemporâneas e com prevalência do informal. Para Fischler (1998), trata-se da "alimentação nômade do citadino apressado".

Sabemos que o café, não apenas para o consumidor americano, faz parte essencial dessa dinâmica apressada. Em termos gerais, a intensificação do ritmo de vida urbana provoca mudanças nos padrões alimentares, especialmente em decorrência de novas condições de gestão do tempo. No Brasil, o processo não foi diferente. Enquanto a urbanização massiva do país ocorreu na década de 1950, a consolidação das praças de alimentação, um dos traços marcantes da vida apressada, ocorreu na passagem dos 1980 para os anos 1990. Nas palavras de Janine Collaço, isso implica uma radicalização de certos valores associados ao estilo de vida urbano:

$\mathrm{Na}$ esteira das transformações das cidades, os restaurantes de comida rápida ingressam em cena para atender pessoas que trabalham, estudam e dispõem de pouco tempo para uma refeição, normalmente efetuada fora de casa em função das distâncias do trânsito complicado, da dificuldade de circulação, o que desenvolveu o surgimento de 'necessidades' como rapidez, higiene, conforto, segurança, preço acessível, liberdade de escolha oferecidos pelos restaurantes fast-food. (COLLAÇO, 2003, pg. 173)

Segundo Collaço (2003), o discurso sobre este ato de comer fora de casa oscila entre duas motivações centrais: necessidade e lazer. Nesse sentido, o comer fora ora

\footnotetext{
Em uma reportagem, lê-se como manchete "A procura dos consumidores por grãos melhores incentivou as grandes torrefadoras a melhorar a qualidade de seus produtos e lançar linhas intermediárias entre $\mathrm{o}$ tradicional café rotineiro e o de microlotes usados por baristas" (Redação Estadão. 29 jan. 2015). A esse respeito, é possível inserir uma indagação. Essas "linhas intermediárias" entre o café ordinário e o altamente especializado são transformações que pertencem ao nicho de mercado ou à indústria de larga escala? À medida que avança o processo de gourmetização, essas fronteiras estão cada vez mais difíceis de serem estabelecidas.
} 
aparece como uma obrigação em virtude das transformações do tempo urbano e do deslocamento casa-trabalho, ora aparece como uma forma de diversão e de fuga da banalidade da vida doméstica e ordinária. Isso apareceu nos discursos apreendidos por Collaço, no que diz respeito à percepção da refeição ideal:

Quando é feita uma refeição, almoço ou jantar, vinculada a alguma obrigação que não permita retornar para casa a fim de alimentar-se, verificou-se uma tendência a valorizar o ambiente doméstico, no qual é possível poder comer de maneira saudável e adequada, moldando os parâmetros para julgar as refeições feitas fora de casa. Essa referência muda ao se considerar aqueles que estão por divertimento na praça de alimentação, o comer reveste-se de sentidos distintos e a casa ganha ares de monotonia e trabalho, especialmente a preparação da refeição, sair para comer permite o acesso a uma refeição incomum em relação àquela realizada no cotidiano. (COLLAÇO, 2003, pg. 174)

Embora o consumo de café não entre diretamente na questão das refeições mais formalizadas (GARCIA, 1997; BARBOSA, 2007), envolve o problema da antinomia valorativa entre o "comer em casa" e o "comer fora de casa" (COLLAÇO, 2003), já que estamos interessados na propagação das cafeterias como parte do processo de gourmetização. É importante dizer que isso implica em um recorte socioeconômico. Segundo dados da pesquisa realizada pela Nielsen, o consumo de café fora de casa é mais frequente nas parcelas da classe A, enquanto que, nas outras classes (inclusive a B e C), o consumo dominante de café ainda é dentro do domicílio. ${ }^{6}$ Além disso, há a questão da divisão dos locais de consumo; as cafeterias são mais presentes na classe $\mathrm{A}$, as padarias na classe $\mathrm{C}$, por exemplo. A despeito da proporção do consumo dentro e fora, o consumo fora de casa, presente em quase todas as classes, aparece para nós como catalisador das mudanças que vêm passando os hábitos alimentares contemporâneos. Em termos teóricos, a refeição seria a transformação do alimento em comida, na medida em que o comer se organiza numa espécie de atividade ritual, cujos elementos são previamente delineados e hierarquizados (café da manhã, almoço, jantar) a partir das categorias compartilhadas por dada população - categorias que envolvem, dentre outras coisas, a reprodução das relações familiares e de gênero (WOORTMANN. 2006). Nessa perspectiva, a própria substância-alimento dependeria de uma série de relações internas ao sistema classificatório

\footnotetext{
6 Pesquisa Nielsen, 2013.
} 
que concede a "qualidade" para o produto ou não, envolvendo outras dimensões além da material e propriamente sensória. Dessa forma, o ato de comer alimenta não apenas corpos biológicos, mas alimenta (e reproduz) relações sociais, isto é, o corpo social:

A comida é uma coisa que, para além de sua materialidade, fala de família, do corpo e de relações sociais. (...) Quando se classificam alimentos, classificam-se pessoas, notadamente os gêneros homem e mulher, pois se o alimento é percebido em sua relação com o corpo individual, este é uma metáfora do corpo social. (WOORTMAN, 2006, pg. 26)

Para Barbosa (2007), a simbolização também constitui a parte mais importante da alimentação. Ela se revela na organização do sistema de refeições. No Brasil, por exemplo, a maioria das pessoas hoje ingere três refeições por dia: café da manhã, almoço e jantar. Diz-se que em geral que as sociedades modernas sofreram um processo de diminuição do número de refeições. Assim, o Brasil supostamente já teve épocas com maior número de refeições: acrescentados o lanche da manhã, o lanche da tarde e o lanche da noite (antiga ceia). Mas isso do ponto de vista das representações, daquilo que possui o status de refeição para as pessoas entrevistadas. Em seu lugar, vieram os "beliscos", "lanchinhos", "porcaria", "besteirinhas", que passam a se proliferar entre as refeições. Segundo Barbosa, essa diminuição do número de refeições, no entanto, não gerou um enfraquecimento do peso simbólico que possuem as refeições para os brasileiros, ainda grandemente marcadas pelo trio arroz, feijão e carne, no almoço e jantar, e pelo trio café, leite e pão, no café da manhã. A autora argumenta que também não houve nenhum aumento significativo da diversidade alimentar no prato dos brasileiros, o que se supõe frequentemente em razão dos processos contemporâneos de individualização dos gostos:

O que os dados dessa pesquisa sinalizam é a presença clara de hábitos alimentares compartilhados e socialmente sancionados pela população brasileira urbana, tanto no que concerne ao conteúdo das refeições como nas atitudes em relação a elas, que transcendem tanto a renda, como os gêneros, as regiões e as faixas etárias. São indicativos disso as altas porcentagens de ingestão de um mesmo cardápio, a presença reduzidíssima de itens considerados "regionais" e de ideologias alimentares contemporâneas nas refeições cotidianas, o atendimento regulado das preferências individuais e a mãe/esposa como responsável pela escolha da comida em $70 \%$ dos casos (...). Isso não significa que não existam variações. Elas existem, tanto no que concerne às faixas etárias, às de renda e às regionais (não se verificaram praticamente quaisquer diferenças entre os gêneros). Mas, além de serem na sua grande maioria pequenas, em termos proporcionais no contexto da 
amostra, ocorrem a partir dos trios feijão, arroz e carne, no caso do almoço e do jantar, e café, leite e pão no caso do café da manhã. Ou seja, aquilo que vamos ter para o café da manhã, o almoço ou o jantar começa de uma base de comidas em comum. (BARBOSA, 2007, pg. 108-109)

Essas conclusões, contudo, dizem respeito às atitudes dos brasileiros em face do "cardápio cotidiano" concebido em termos gerais. No artigo em questão, a autora praticamente não toca na questão das práticas de comer fora de casa. Os dados foram extraídos da Pesquisa de Hábitos Alimentares Brasileiros (2006), realizada em parceria pela Toledo Associados e pela ESPM, com a participação da autora. Na etapa qualitativa, foram realizados 50 grupos focais; na etapa quantitativa, houve a aplicação de questionários a 2136 pessoas, isso em dez cidades brasileiras com mais de 1 milhão de habitantes. Pelo que parece, as pessoas foram abordadas apenas uma vez, o que dificulta a apreensão das variações da prática alimentar ao longo do tempo, incluídos aí os desvios de rotina, desvios que fazem parte constitutiva do cotidiano alargado. Deste modo, a utilização de novos itens alimentares e a possível diversificação da dieta pode se dar de uma forma mais sutil, que talvez escape na aplicação de um questionário discursivo. $\mathrm{O}$ questionário, como toda prática de inquisição investigativa, serve bastante para lidar com o componente representacional da conduta, na medida em que os modelos discursivos puxam sempre para uma normatividade ideal - patente nas noções de "refeição ideal", "cesta de alimentos", "seleção de menus" e "cardápios". Nesse processo, os meandros da conduta cotidiana são enxugados através de um arranjo abstrato, forjado na situação de pesquisa sujeito-objeto, e resultando no mapa das preferências do "cardápio cotidiano". A nosso ver, essa escolha metodológica dificulta, por exemplo, a apreensão das transformações decorrentes do processo de globalização nas duas últimas décadas. A própria noção de "refeição" clama pelo caráter tradicional das representações culturais mais amplas, nacionalmente marcadas.

Outros autores apontam para a mundialização do plano alimentar. É o caso de Renato Ortiz (2000) e Rosa Garcia (2003), que chamam atenção para a proliferação dos alimentos industriais. A apreensão empírica da importância dos alimentos industriais não se dá no nível representacional, através dos quadros de referência simbólica (o status de refeição), mas na propagação de novas práticas de consumo, que são medidas pelos 
números do mercado. Segundo Garcia, uma "dieta afluente" caracteriza os países em situações de prosperidade econômica, marcada por alimentos de grande densidade energética, ricos em gordura e açúcar refinado simples. Esse padrão de consumo é resultado direto da mundialização da cultura. No início da década de 1990, a abertura do mercado brasileiro repercutiu no crescimento das importações de alimentos - só entre 1992 e 1995, a importação de produtos alimentares industrializados cresceu 409\% (GARCIA, 2003, pg. 486). Em conjunto, a industrialização da dieta, a diminuição das refeições domésticas e o aumento da oferta de serviços gastronômicos diversos, ajudaram a cristalizar os valores da modernidade-mundo no país (ORTIZ, 2000): funcionalidade, mobilidade e racionalidade. Isso se dá porque a globalização, mais do que mera internacionalização do comércio, envolve uma integração funcional entre atividades econômicas diversas, que passam a ser padronizadas. ${ }^{7}$ Nesse movimento, até mesmo a reciprocidade entre uma determinada cultura e seu lugar de origem é posta em cheque:

Da mesma forma que os orixás preservam suas qualidades de origem, os hábitos alimentares se moldam no espaço. No entanto, a modernidade é o contrário da fixidez. Ela é mobilidade. O princípio da circulação, que se realiza nas reformas urbanas (Paris de Haussmann, Viena de Camilo Sine), nos meios de transporte (trens, automóveis, aviões), na moda (a fugacidade dos modelos), penetra também nossos hábitos recônditos. A alimentação deixa de ser um universo ao abrigo da fragmentação e da rapidez do mundo moderno. O advento das técnicas de conservação, o barateamento do transporte, a invenção da comida industrial transformam radicalmente este quadro. Por isso alguns estudiosos começam a falar de internacionalização dos comportamentos alimentares. "Tudo se passa como se os hábitos alimentos, regionais ou nacionais, caracterizados por um número limitado de produtos, e uma certa monotonia, recorrente nas preparações culinárias, explodissem os meios técnicos - conservação, transportes, distribuição dos produtos - e o nível de renda, permitindo a expansão do consumo a uma gama de produtos não tradicionais." Na verdade, durante o século XX, dois movimentos acentuam o processo de mundialização. Primeiro, a diversificação dos produtos. Uma região já não se define apenas pela presença de um número limitado de alimentos cultivados ou fabricados em suas áreas. Segundo, a passagem da cozinha tradicional, com a preparação de pratos típicos, para uma cozinha industrial. (...) Os alimentos descolam de suas territorialidades para serem distribuídos em escala mundial. Não existe nenhuma "centralidade" nas cervejas, chocolates, biscoitos, refrigerantes. Trata-se de produtos consumidos mundialmente e distribuídos por grupos multinacionais. (ORTIZ, 2000, pg. 79-80)

\footnotetext{
${ }^{7}$ Não confundir padronização (pattern) com homogeneização (standard). O primeiro processo diz respeito à disseminação de modelos culturais hegemônicos, que não necessariamente excluem a diversidade. Os modelos globalizados convivem com a diversidade, formatando as diferenças a partir de um repertório de estilos comuns. Já a homogeneização (standardization), esta sim, refere-se à massificação do mesmo. Cf. ORTIZ, 2000.
} 
Seguindo Ortiz (2000), não acreditamos que a propagação dos alimentos industriais ou dos serviços industrializados de preparação da comida fora de casa, tal como as redes de fast-food, são razões suficientes para resultar numa homogeneização do gosto, em termos gerais. Essas tendências convivem com uma crescente estilização da prática culinária, em especial no segmento de luxo, junto com uma moderna valorização das cozinhas regionais. Ao lado dos valores da rapidez, higiene, conforto, preço acessível e funcionalidade mobilizados nos restaurantes de comida rápida, surgem uma série de estabelecimentos que, embora destinados ao comer fora de casa, não estão envoltos pelo prisma da comodidade/ praticidade e sim pelo prisma de uma maior espetacularização da comida, o que implica na criação de novos rituais de experimentação social. Por exemplo, Ortiz cita o caso dos consumidores "sócio-conscientes", aqueles consumidores mais voltados para os alimentos naturais e que abominam os hambúrgueres de carne. Ora, esses consumidores também são resultado de uma cultura mundializada:

Comida padronizada, ambiente familiar, decoração brega, massificação contrapõem-se a comer em restaurantes, atendimento individualizado, alimentos sadios, bom gosto. Tudo se passa como se uma era fordista tivesse sido superada por outra, flexível, adequada ao bom gosto e à individualidade dos clientes. O fast-food surge assim como um valor ultrapassado pela modernidade dos customized products. (ORTIZ, 2000, pg. 209)

Portanto, não apenas biscoitos, chocolate e refrigerantes são símbolos da cultura global. ${ }^{8}$ Uma vez que o sistema de produção, distribuição, divulgação e consumo de alimentos ganhou terreno, abre-se espaço para o surgimento de novas modalidades de consumo. Essas novas modalidades são marcadas não mais pelo lastro nacionalista da comunidade de origem, mas pelos atravessamentos complexos do mercado global:

Diferença e similaridade se combinam. (...) doravante, as condutas se diferenciam em função de segmentos de consumo, e não mais segundo suas territorialidades. O impacto das culturas locais é relativizado. (...) Para compreender a diversidade padronizada dos estilos de vida, os marketeers começam a operar com tipologias transnacionais. É possível, desta forma, falar em consumo "internacional sofisticado", envolvendo pessoas que os publicitários chamam de cidadão do mundo, viajantes que se deslocam por

8 Para Ortiz (2000), alguns exemplos da modernidade-objeto são os biscoitos Nabisco, iogurtes Danone, os chocolates Nestlé, as cervejas Budweiser, os tênis Reebok, os táxis, os objetos-mobílias, os aeroportos, os hotéis internacionais, as cidades turísticas, os jeans, os cigarros Malboro, a música Pop, além do Mc Donald's e da Coca-Cola. 
todo o planeta, e têm suas vidas pautadas pelas exigências mundializadas; em consumo "menos sofisticados", mas ainda referente a indivíduos abertos às coisas do exterior; e consumo "provinciano", os que se contentam com as oportunidades oferecidas por suas localidades. No contexto do mercado global as classificações transnacionais substituem as divisões de classe. (ORTIZ, 2000, pg. 173-175)

Diversidade padronizada dos estilos de vida, expressão de aparente contradição, mas que demonstra o quanto o fenômeno da globalização se realiza através da diferenciação. Se atentarmos para a história do café, veremos em que medida o processo de industrialização alimentar é substituído por uma segmentação do mercado e pelo surgimento de categorias transnacionais de consumidores - baseadas no nível de vida e não numa cultura territorializada. Tornou-se comum falar da evolução histórica da qualidade do café em termos de "ondas" (waves). A expressão "terceira onda do café" foi primeiramente formulada por Trish R. Skeie, em 2003, num jornal norueguês especializado no mercado de cafés especiais. Depois de ela ter lançado a ideia, a tipologia das três ondas foi sucessivamente refinada por outros autores e hoje aparece nas reportagens das mais diversas publicações mundo afora - incluindo uma reportagem no caderno Paladar do Estadão: "Vivemos a terceira onda do café" (23 jul. 2014). A ideia é bastante simples. A primeira onda é a onda da massificação do café, que se estendeu dos anos 1950 até o início dos anos de 1990. Nesse período, o café funcionava mais como um "sistema de entrega de cafeína" (MANZO, 2010) e geralmente era preparado em grandes coadores (percolators) ou urnas (urns) que ficavam expostas em escritórios e salas de banquete. Também nos supermercados, os clientes de então compravam seus cafés em embalagens hermeticamente fechadas, nas quais o grão já estava moído e pronto para ser diluído em água quente. Marcas bastante populares nas prateleiras norte-americanas eram Folgers e Maxwell House, ambas vendiam um café embalado seco e congelado, o que facilitava a conservação. ${ }^{9}$

\footnotetext{
9 Os anos 1950 foram um período de conglomeração para o mercado de cafés nos Estados Unidos. Empresas torrefadoras regionais, como a Folgers, a Hill Brothers e a Maxwell House, foram absorvidas e concentradas nas mãos de grandes corporações. Em 1965, a General Foods (GF), agora dona da Maxwell House, controlava $15 \%$ do consumo mundial de café, seguida pela Procter and Gamble (P\&G), que agora era a segunda maior empresa torrefadora de café nos Estados Unidos (LUTTINGER \& DICUM, 2006).
} 
Figura 1 - A primeira onda de café
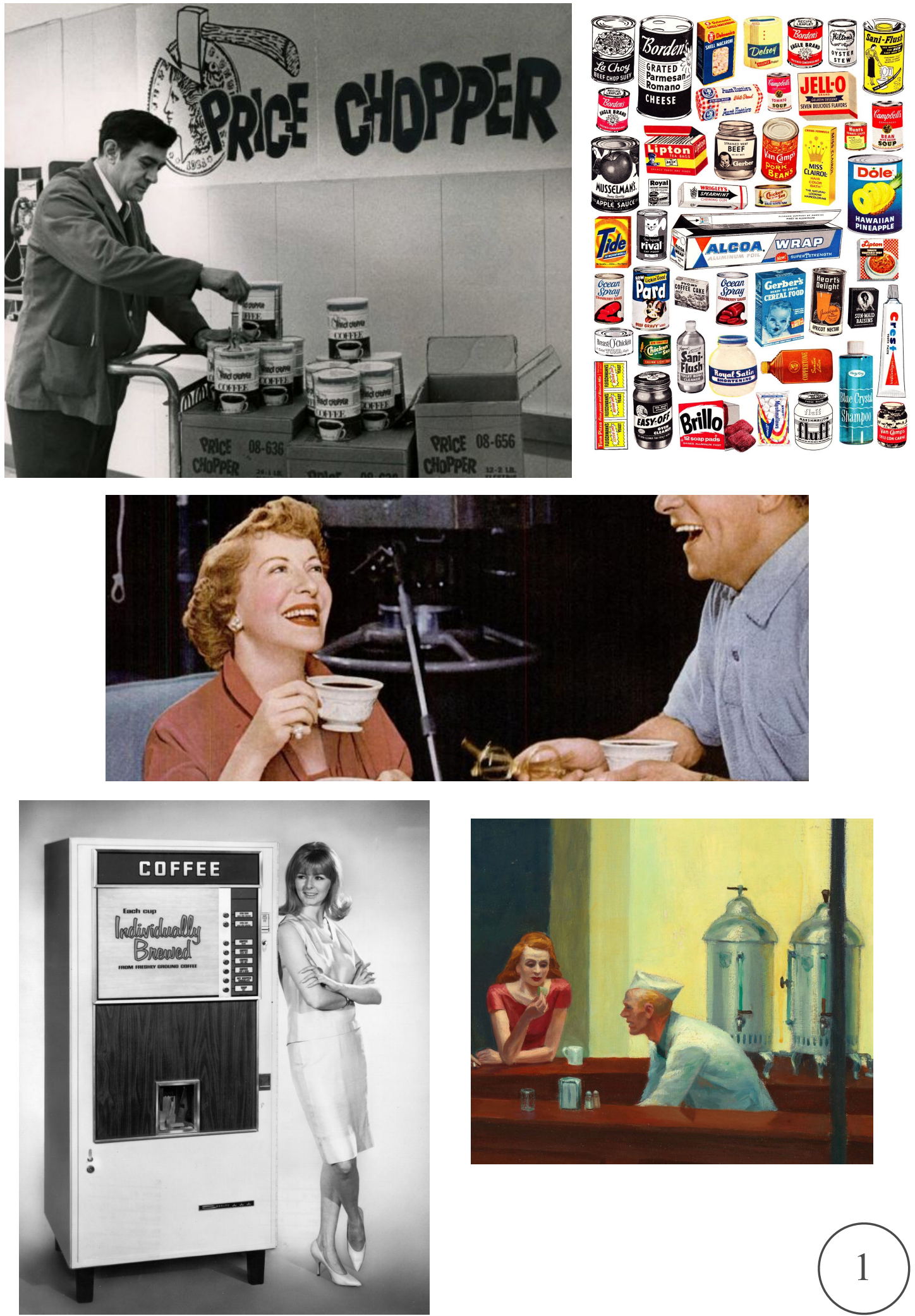

Fonte: montagem elaborada pelo autor a partir do Google Imagens 
A segunda onda do café foi marcada por uma elevação da qualidade média do café, pela proliferação de grandes cadeias de cafeteria gourmet e pelo crescimento do interesse global por café espresso. A ascensão da Starbucks, empresa fundada em 1971, a nível mundial também ocorreu nos anos 1990. A partir daí houve uma popularização do vocabulário de algumas formas de preparo do café: cappuccino, latte, french roast, etc., bem como os termos técnicos utilizados pela própria Starbucks para se referir aos tamanhos da bebida, tall, grande, venti. Esse também foi o momento em que se cristalizou a preferência do mercado pela espécie arábica em detrimento da robusta. ${ }^{10}$ Seguindo as palavras de Skeie, os anos 1990 marcaram o período em que a maioria dos atuais especialistas de café entraram no mundo do café:

Nossa entrada foi artesanalmente impulsionada. Alguém nos revelou as diferentes origens de café e os estilos de torrefação. Nós olhamos para a indústria do vinho como fonte de inspiração na definição de metas e estratégias. Nós começamos as lojas com pequenas operações de torrefação e ótimas seleções de chá. Logo estávamos servindo espresso e fazendo viagens para Itália e para os países produtores. (SKEIE, 2003)

10 Robusta, tecnicamente falando, é uma variedade da espécie Coffea canephora. Voltaremos a essa diferenciação mais adiante no texto. Conilon é uma outra variedade que está no mesmo patamar da classificação. Frequentemente, adota-se o termo robusta genericamente para se referir à espécie canephora como um todo, em contraste com a espécie arabica. 
Figura 2 - A segunda onda do café



Fonte: montagem elaborada pelo autor a partir do Google Imagens

A terceira onda do café é marcada pelo crescimento da quantidade de torrefadores artesanais, bem como de revendedores de café verde e de pequenas cafeterias que valorizam o ofício do barista ao invés de focar no trabalho automático da máquina de espresso. Essa onda também é marcada pela valorização do frescor do café $v s$ as técnicas de conservação e de embalagem das grandes cadeias de café. Outra característica da última onda é que ela coloca em xeque noções estabelecidas do preparo do café, tais como a noção de um "tempo padrão de extração" da escola italiana de espresso. Ao flexibilizar e complexificar os protocolos de preparo do café, os baristas e apreciadores da bebida tornam-se aliados no empenho experimental, o que abre espaço para diferentes formas de 
se tomar café. Numa reportagem intitulada "The BGA and the Third Wave", Nicholas Cho

(2005) define da seguinte maneira essa terceira etapa na evolução da qualidade do café de uma forma geral:

Então o que é essa Terceira Onda? Numa forma intencionalmente esotérica, eu costumo me referir à Terceira Onda como deixar o café falar por si só. Durante as duas primeiras ondas, nós apreciamos o café pelo que ele nos dava: cafeína, uma bebida quente para bebericar e apreciar uma conversa, uma bebida para modificar com adoçante, cremes lácteos (ou não-lácteos), xaropes, leite vaporizado, etc. A terceira onda é sobre apreciar o café pelo que ele é. (...) Com as novas safras surgem novos sabores que irão afetar o blend de espresso que elas fazem. Misturar diferentes colheitas (blending) e torrar os grãos para chegar num "perfil de sabor" pré-determinado, ano após anos, acreditando que a consistência é acima de tudo o maior objetivo desse processo... isso é um pensamento da segunda onda. Com cada novo lote de café, a torrefadora ganha uma nova paleta de cafés para trabalhar, e aprender a trabalhar com essa paleta é parte do pensamento da terceira onda... não apenas tentar fazê-los virarem o que queremos deles. (...) Falando sério, enquanto alguns anos atrás, o barista era alguém que apenas operava uma máquina de espresso, um barista da terceira onda é um estudioso do grão. Um barista da terceira onda não apenas se preocupa em "como eu posso apressar e fazer essas bebidas para esses clientes o mais rápido possível?". É questão de extrair tudo o que é bom do seu espresso, tomando a energia e o tempo que for preciso... e servir ISSO aos seus clientes. Um barista da terceira onda é um embaixador do café. (CHO, 2005) 
Figura 3 - A terceira onda do café

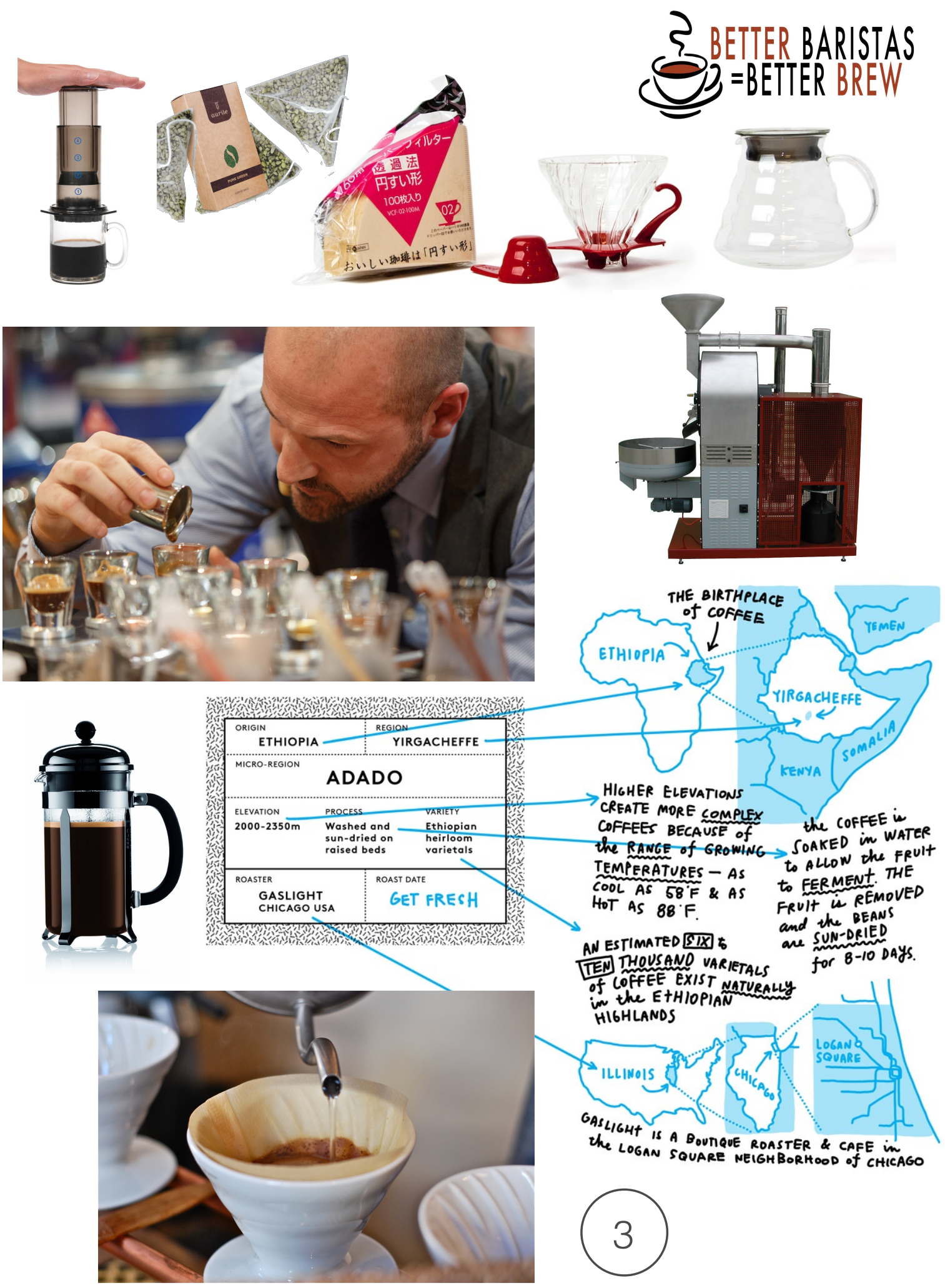

Fonte: montagem elaborada pelo autor a partir do Google Imagens 
A nova tendência dirige grande parte da sua atenção para o papel dos intermediários da cadeia produtiva do café, isto é, atores que trabalham do campo-à-mesa (field-to-cup actors) e que agora podem encurtar a distância entre o consumidor e o produtor, distância que antes precisava passar pelas mãos dos corretores de café, dos torrefadores de larga escala e dos revendedores. Agora os grãos são facilmente comprados ainda verdes e torrados ao modo da casa nas pequenas e artesanais cafeterias que se proliferam nos mais movimentados centros urbanos. As cafeterias pesquisadas para a presente pesquisa possuem inúmeros traços da "terceira onda". Dentre outras características, todas elas buscam rastrear o processo de torra do grão oferecido, ter uma relação mais próxima com esse processo, e todas elas também oferecem diversos modos de preparo da bebida. De todo modo, a proximidade do preparo do barista com o cliente é traço essencial dos serviços oferecidos por essas cafeterias. No debate sobre o setor de serviços, costuma-se falar que a interação entre comprador e vendedor é fundamental para a provisão do serviço. Ora, no mundo das cafeterias gourmets, é exatamente essa interface provedor-usuário que constitui o cerne da experiência comercializada.

Figura 4 - Os diferentes tipos de preparo


Fonte: Site Café más té11

Ao me dirigir especificamente ao circuito de consumo de café gourmet, procuro desvendar e desembaraçar as características dessas três ondas no caso brasileiro. Como já dito, me interessa entender a formação de um tipo específico de estilo de vida voltado para a percepção e apreciação dos mínimos detalhes dos produtos ofertados pelo mercado. Esse estilo de vida faz parte ou é resultado direto da formação do mercado internacional de

\footnotetext{
${ }^{11}$ Disponível em: <http://www.cafemaste.es/a-cada-cafetera-su-tipo-de-molido/>. Acesso em: 24 ago. 2015.
} 
produtos gourmet. A diversidade sensória proporcionada por tais experiências hedonistas do mercado não deixa escapar certo teor ascético na formação dos quadros de consumidores típicos, pois necessita de um rigoroso aparato sensorial humano capaz de lidar com essas pequenas diferenças internas aos produtos ofertados. ${ }^{12}$ É aí que entra o método etnográfico como estratégia sociológica de abarcar essa por ora difusa interseção entre as cafeterias, as prateleiras dos supermercados $\mathrm{e}$ as atitudes práticas dos consumidores, formando esse amálgama mercadológico do gourmet - ilustrativo a esse respeito é o fato de a palavra "gourmet" ser utilizada tanto para se referir aos estabelecimentos e aos produtos, quanto às pessoas que integram esse trajeto. A meu ver, o café é um item estratégico para se entender a formação desses circuitos, pois, de um lado, o caso brasileiro vem associado ao peso da tradição colonial de exportação de produtos agrícolas (há mais de 150 anos o Brasil detém a posição de maior exportador de café do mundo); de outro, seu alto teor de cafeína é diretamente associado ao estilo de vida veloz das grandes metrópoles, no entanto, essa dubiedade de produto nostálgico do passado rural nacional e de estimulante moderno do trabalho citadino não impede, apesar da superposição e sobrecarga semiótica do café, que o produto seja requalificado na passagem para o século XXI como parte de um circuito mais geral de produtos que não estão exclusivamente ligados nem ao veloz, nem ao lento; nem ao urbano, nem ao rural, mas compõem uma nova síntese.

Sobre a história do grão, podemos dizer algumas coisas como ponto de partida. $\mathrm{O}$ café é algo que não se encontra como tal na natureza, pois é um produto humano. É uma

12 Aqui podemos estabelecer um paralelo com os desdobramentos da tese eliasiana do "processo civilizador" em Cas Wouters (1986). Segundo o autor, vivemos, desde os anos 1960, um período de afrouxamento das normas de comportamento (regras de etiqueta), o que não significa uma diminuição na margem de auto-controle. Isso porque saber-se permitir oscilar entre comportamentos regrados e comportamentos relaxados ou lúdicos, e manter-se socialmente eficaz nessa oscilação, é algo que requer uma grande carga de tensão e aprendizado. Nesse sentido, no caso do café, o ato de desenvolver a percepção sensória, ou aquilo que chamamos de disposição estética-gustativa, é um dos resultados desse afrouxamento das restrições, na medida em que passamos a estar envoltos pela experiência de sentidos que, historicamente, eram considerados "baixos" e "inferiores": o olfato, o paladar e o tato (componentes fundamentais da experiência gastronômica). No entanto, desenvolver a capacidade de discernir os alimentos nos seus componentes internos é algo que, por mais aberta que esteja às vicissitudes da diversidade sensorial humana, requer aprendizagem rigorosa e auto-controle. O processo também pode ser entendido como um retorno ao componente lúdico da existência humana, em detrimento das rigorosas regras de conduta conhecidas como "civilizadas". Nesse sentido, a civilização ocidental seria, e Freud foi o primeiro a formular com todas as letras, a contração da violência e da realização do prazer na existência humana e seu reposicionamento no domínio íntimo, o que implica um afastamento cada vez maior da própria animalidade do homem. 
bebida que precisa ser extraída de determinadas espécies de planta, sendo a Coffea arabica a espécie mais utilizada comercialmente, ao lado da Coffea canephora. ${ }^{13}$ Para se ter uma noção, a maioria dos cafés brasileiros torrados são misturas (blends) dos dois grãos, tendo em vista o baixo custo de produção. ${ }^{14}$ Os cafés $100 \%$ arábica são vendidos como cafés especiais e gourmets, alcançando preços de 2 a 4 vezes maiores que as misturas. Pelo que sabemos, o cultivo das espécies da planta Coffea, começando na África, se espalhou por vários continentes, passando daí para a Arábia, depois Ásia oriental, América latina e de volta para a África e para a Ásia oriental (TOPIK, 2009; 2012). Hoje, a produção mundial se distribui mais ou menos da seguinte maneira, o Brasil detendo aproximadamente 1/3 do total exportado dos grãos verdes:

Gráfico 1 - Produção mundial de café, por região (2011/12 a 2014/15)

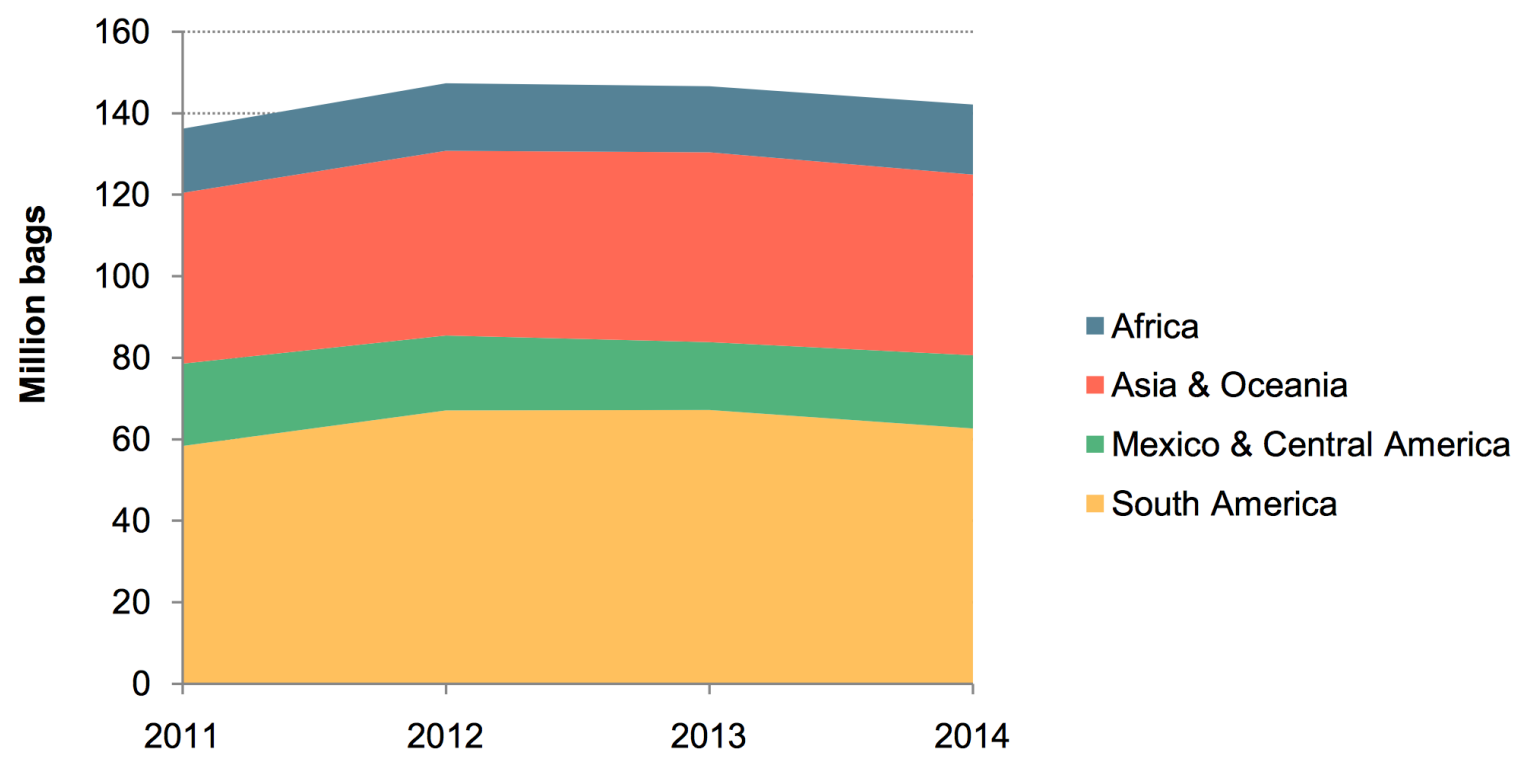

Fonte: International Coffee Organization

13 Para se ter uma noção da diferença de preço entre as espécies, o arábica estava custando R \$ 455,00/saca em Dezembro/2014, enquanto o conilon, variedade de robusta que é mais comercializada no Brasil e que é muito utilizada na produção de cafés solúveis, estava custando R\$275,00/saca, segundo dados do Informe Estatístico produzido pelo Departamento do Café (DCAF-MAPA). A participação do arábica no total das exportações brasileiras é de $81,0 \%, 9,5 \%$ o robusta, $9,4 \%$ o solúvel e apenas $0,1 \%$ torrado \& moído, segundo estimativas de Dezembro/2014 do Conselho dos Exportadores de Café do Brasil (CeCAFÉ). Já para o consumo interno, a proporção de robusta é provavelmente maior, já que ele compõe entre $40 \%$ e $60 \%$ dos blends comercializados por marcas próprias de grandes varejistas (como Carrefour).

14 A noção de blend designa o café que é composto ou por mais de uma variedade do grão (ex: Catuaí ou Bourdon), ou por mais de uma espécie (Arábica ou Robusta), ou pela mistura dos grãos produzidos em diferentes regiões. 
Já como hábito de consumo, o café passou das montanhas etíopes para o Iêmen, entre o século V e XIV, quando era consumido junto com manteiga na forma de pasta ou através de um complexo ritual em que se torrava e moía o grão em casa para, em seguida, servir a água quente diretamente sobre o pó em pequenas cuias. Depois disso, o café passou para a Arábia do Sul, onde se tornou essa bebida de decocção negra, o "café turco", parecido com o café europeu só que com mais borra e mais consistência (LEMPS, 1998). ${ }^{15}$ No Oriente Médio, os árabes também começaram a acrescentar especiarias como aromatizantes para suavizar o amargor proveniente da torra do café; dentre as especiarias, a canela, o cardamomo, o alho e o gengibre. Ele chegou em Meca no final do século XV, em Cairo no início do XVI e em Constantinopla por volta de 1554 . Já por volta de 1570 , os Venezianos passaram a comercializar o café para o restante da Europa, como produto de luxo, e foi também nessa época que começaram a filtrar o café por causa da borra, tornando-o mais palatável aos novos consumidores dos países vizinhos. Chegou em Paris no final do século XVII, e mais ou menos no mesmo período também em Londres. ${ }^{16}$ Em certo sentido, o consumo ocidental do café se consolidou a partir do espaço público criado pelas cafeterias burguesas, que se propagaram massivamente na Paris e Londres do século XVIII. No século XVII, por exemplo, o número de botequins que serviam café em Paris praticamente duplicou - de 380 no ano de 1720 para mais de 600 no final do século (LEMPS, 1998). Diz-se também que Londres chegou ao final do século XVIII com mais de 2.000 cafeterias (RUZICH, 2008). A partir daí, os séculos seguintes trataram de generalizar seu consumo para as parcelas menos abastadas da sociedade ocidental, penetrando o lar da moderna família trabalhadora. Já em meados do século XVIII, o café com leite pôde tornar-se uma bebida popular na França, tendo em vista a imitação do comportamento das elites por parte do povo.

15 No mundo árabe o café era conhecido como qahwah, e tornou-se uma bebida popular no Iêmen em meados do século XV. Como o nome qahwah era originalmente dado ao vinho, a etimologia indica a associação inicial do café a uma bebida intoxicante e condenada pelos preceitos religiosos, no começo de sua proliferação pelo mundo árabe. Sua descoberta como bebida de decocção é atribuída a Muhammad alDhabhani, um acadêmico e membro da ordem mística sufista do Islã. Antes da popularização, a bebida tinha uma associação religiosa positiva, quando os sufistas usavam o café para afastar o sono em cerimônias religiosas noturnas (STANDAGE, 2005).

16 Em 1652, Pasqua Rosée abriu a primeira cafeteria em Londres, um serviçal grego de um mercador inglês que havia aprendido a beber café na Turquia (BEHR, 1992). Em Paris, a primeira cafeteria foi aberta por um italiano, La Procope, em 1686, pouco mais de trinta anos depois de Londres. 
Assim, primeiro como produto exótico e item de luxo das cortes aristocráticas, aos poucos o café foi sendo associado ao estilo de vida moderno e veloz das grandes cidades, até tornar-se símbolo da burguesia. Essa transposição de significado social se radicalizou na passagem do século XIX para o século XX. Na Itália, por exemplo, no começo do século XX, o café era geralmente consumido em espaços públicos onde as máquinas de expresso, com suas barulhentas caldeiras de vapor quente e com seus detalhes deslumbrantes em bronze, simulavam grandes locomotivas. ${ }^{17}$ A própria palavra italiana espresso foi derivada do francês exprès e do inglês express, que primeiramente significava algo que tinha sido feito "pronto para encomenda" e que depois, por extensão, foi associado às locomotivas que iam de um lugar a outro sem parar, entregando tais encomendas (SCHNAPP, 2001). Já segundo Ernesto Illy (2002), a palavra espresso se refere a um serviço feito sob encomenda especialmente para uma ocasião, ou melhor, feito na hora, a la minuta.$^{18}$ Em 1901, Luigi Bezzera patenteou a primeira máquina de expresso feita especialmente para restaurantes; outros atribuem a Fernando Illy a invenção da moderna máquina de espresso, em 1904 (LUTTINGER \& DICUM, 2006). A partir do começo do século XX, a atitude moderna de se tomar um espresso na rua foi sendo incorporada ao ethos das classes mais abastadas. A respeito das novas máquinas de expresso, Schnapp diz o seguinte:

Elas reforçaram e reinterpretaram a convicção de longa data de que café forte era o licor viril com o qual os homens modernos alimentavam suas caldeiras corporais. E mesmo se o café fabricado por esses gigantes vaporizados tinha frequentemente um gosto queimado, a bebida era rica em poder e energia, intensa e feita para ser rapidamente consumida. Elas traduziam os valores de eficiência e excitação associados ao trem expresso em uma bebida cotidiana, em comparação com a qual o café doméstico era apenas uma imitação lenta e pálida. (SCHNAPP, 2001, pg. 251) (19 $^{19}$

17 Vale lembrar que, antes da popularização das embalagens de café torrado, protagonizada pelos Estados Unidos nas primeiras décadas do século XX, as cafeterias públicas serviam também como locais de torrefação e moagem dos grãos, além do preparo da bebida. Nesse quesito, as cafeterias da Europa mantiveram a tradição por mais tempo. (Cf. TOPIK, 2012). A terceira onda de café reatualiza esse antigo modelo de cafeteria como local de micro-torrefação.

18 Esse também foi o significado transmitido pelo instrutor Renato Gutierres no curso de barista realizado no Coffee Lab, experiência etnográfica que será melhor explorada nos capítulos II e III.

19 "They reinforced and reinterpreted the long-standing conviction that strong coffee was the virile liquor with which modern men powered their corporeal and corporate boilers. And even if the steam-brewed coffee that these behemoths turned out often tasted burnt, the brew was power-packed, intense, and quickly consumed. It translated the values of efficiency and excitement associated with the express train into an everyday beverage in comparison to which domestic coffee was but a slow and pallid imitation." 
A bialetti foi das primeiras máquinas caseiras de expresso que conseguiu traduzir a velocidade e o glamour das cafeterias para o espaço doméstico. "In casa un espresso come al bar" era o mote de sua campanha publicitária nos anos 50 (SCHNAPP, 2001, pg. 264). Até hoje ela detém esse caráter distintivo. Desde sua primeira fabricação, já foram vendidas cerca de 200 milhões bialettis em todo o mundo, sem contar as imitações falsificadas da marca. Há um estudo interessantíssimo (SCHNAPP, 2001) a respeito das condições sociais que entram em jogo na construção da bialetti, o famoso modelo italiano de cafeteira doméstica. Segundo Schnapp, a cafeteira italiana, inventada por Alfonso Bialetti em 1933, teve seu design de alumínio grandemente influenciado pelo ideal fascista de progresso dos anos 30. Na Itália da época, o alumínio havia emergido como a escolha mais autárquica dentre as matérias-primas, visto que o país era pobre em termos de minério de ferro, carvão, petróleo, e em compensação abundante em jazidas de bauxita e leucita, que são os minérios utilizados na composição do alumínio industrial. A partir disso, o governo incentivou diretamente a utilização do alumínio nas indústrias, agora proclamado como o "metal italiano por excelência", também porque sua leveza expressava o ideal progressista da época - lê-se em 1935, numa revista fundada pelo governo, que o alumínio é la materia reale dell'irreale velocità. A cafeína era a combinação perfeita para tal contexto, já que a ela era associado um efeito disruptivo e criativo sobre o homem; em certo sentido, portanto, o café detinha uma afinidade com o fascismo, que pretendia ter um efeito disruptivo e inovador em relação ao passado italiano. Foi nesse contexto que a fábrica de Alfonso Bialetti soube como nenhuma outra transfigurar tal imaginário em soluções práticas de design. 
Figura 5 - A bialetti e o imaginário de modernidade
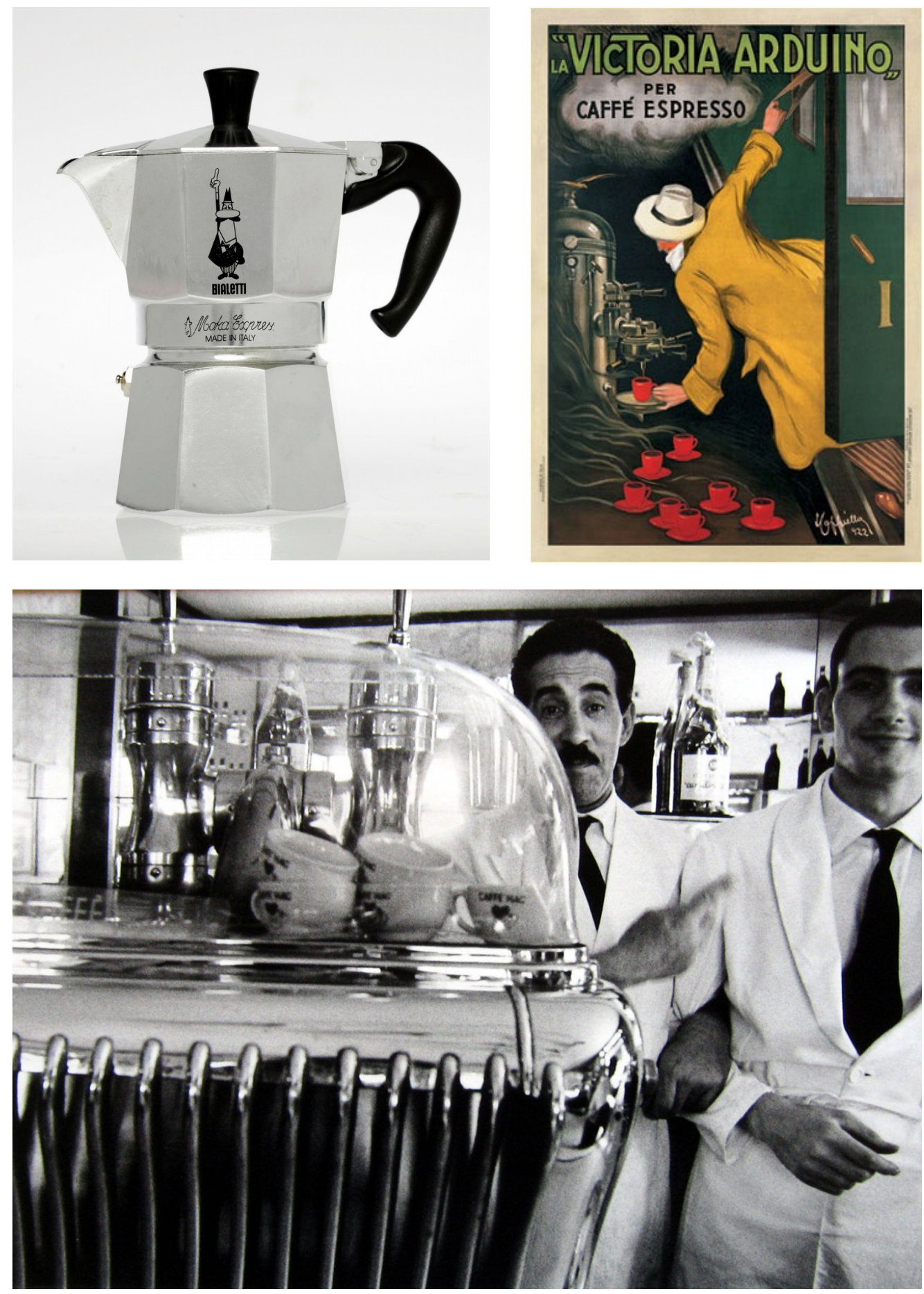

Fonte: cafeteira bialetti; ${ }^{20}$ pôster de Leonetto Cappiello para La Victoria Arduino (1922), Wikimedia Commons; fotografia de William Klein, "Two Waiters in Café", Roma, $1956^{21}$

${ }^{20}$ Disponível em: <http://blog.incipeindustries.com/wp-content/uploads/2010/07/Bialetti-Moka-ExpressEspresso-Coffee-Maker.jpg>. Acesso em: 24 ago. 2015.

21 Disponível em: <https://www.1stdibs.com/art/photography/william-klein-two-waiters-cafe-rome/ida_4491/>. Acesso em: 24 ago. 2015 . 
Essa afinidade eletiva que se estabeleceu entre o imaginário de modernidade do fascismo italiano dos 1930 e o imaginário de modernidade ligado aos cafés e às locomotivas é, para nós, ilustrativa de um dos tipos de análise que é possível ser realizado quando se toma por objeto a comida de um território circunscrito. $\mathrm{O}$ que entra em jogo aqui é a função rememorativa da comida, como signo histórico de estilos de vida mais amplos. Nesse plano, a realidade concreta do ato de tomar café ganha contornos semióticos grandiosos, definidos pela extensão da associação dos signos que entram em contato com o signo-base café. O café passa a ser percebido como uma expressão dos modos de ser moderno, do requinte e da velocidade próprias às grandes metrópoles. Nessa perspectiva, o consumo concreto da substância seria uma decorrência das associações entre signos, que podem fazer mais ou menos sentido, de acordo com a época e o contexto. Nosso interesse pela gourmetização do café envolve aspectos que não são abordados por essa perspectiva mais culturalista, preocupada tão somente com a orquestração ampla de estilos de vida e com a história do imaginário coletivo. Nos interessa o problema das transformações sociomateriais envolvendo as técnicas de intervenção na produção do produto, aquilo que é atualmente chamado de tecnociência. Por exemplo, quando a indústria alimentar se vale de flavorizantes, conservantes, aditivos e fertilizantes, percebidos na textura e no sabor por quem compra. Aqui não estão em jogo apenas signos e associações entre signos que, ao serem acionados, delineiam os caminhos oficiais pelos quais percorre a memória coletiva. Aqui estão em jogo as substâncias, não plenamente traduzíveis em ideias ou signos (textuais), que definem o caráter duro e imediato da materialidade que nós iremos trazer para perto do corpo. Essa materialidade age sobre o corpo humano e molda as formas históricas que uma coletividade irá experienciar a vida cotidiana. Esse é o caso do café e de outras substâncias estimulantes que se tornaram parte de um conjunto de práticas compartilhadas pelos países da economia globalizada.

Apesar do desenvolvimento da cultura de consumo do café ter se consolidado, depois das cafeterias turcas, com o surgimento dos restaurantes e das cafeterias na Europa Ocidental, para a qual o café era uma bebida exótica importada do Oriente, a consolidação do mercado em geral, quando levamos em conta os cafés que são comercializados já torrados e embalados, aconteceu nos Estados Unidos. Os Estados Unidos, desde o século 
XIX, compravam grãos verdes de outros países e torravam em seu próprio território. Algumas empresas foram se destacando no mercado varejista decorrente da importação e torrefação dos grãos. Tal processo nos interessa na medida em que constitui o berço da formação de um mercado mundializado de cafés torrados. Isso porque, no contexto atual, a corporação global toma o planeta como mercado único e define suas políticas não mais presa a delimitações regionais. Esse movimento de agregação, que tem como consequência uma desterritorialização dos produtos industriais, possui uma história. A formação de conglomerados na indústria americana de café se intensificou a partir da metade do século XX. ${ }^{22}$ A Maxwell House, maior empresa de torrefação de cafés nos Estados Unidos até os anos 1980, já havia sido comprada pela General Foods (GF) em 1928. Para se ter uma ideia da lucratividade do mercado de cafés, a empresa Maxwell House chegou a ser responsável, em meados do século, por cerca de um terço dos lucros de operação da General Foods, hoje uma grande multinacional composta também pelos grupos Kraft e Philip Morris (da Marlboro). No começo do século XX, Folgers, Arbuckle's, Hills Brothers, Maxwell House e Eight O' Clock eram algumas das empresas torrefadoras regionais importantes nos Estados Unidos. Fundadas no século anterior, já haviam se consolidado no mercado quando chegou a Primeira Guerra Mundial. No período que se estendeu até a década de 1950, algumas dessas torrefadoras se tornaram verdadeiras marcas nacionais e passaram a controlar a maior parte da circulação de café torrado no mercado americano. Juntas, essas empresas de torrefação também usaram a entidade National Coffee Association (NCA) como um grupo de lobbying para conseguir impor novas políticas econômicas em relação à importação-exportação de café, no intuito de amenizar a baixa dos preços que começou na década de 1950.

Com a parceria do Brasil e da Colômbia, os dois principais fornecedores de grão verde para os Estados Unidos, essas grandes torrefadoras obtiveram uma vitória política em 1962, com o International Coffee Agreement (ICA), que funcionou como um cartel que assinalava cotas para os países produtores e para os países consumidores, impedindo que a superprodução fizesse despencar os preços no mercado internacional. Nas décadas seguintes, também surgiram outros conglomerados (hoje multinacionais) e esses passaram

\footnotetext{
${ }^{22}$ A exposição que se segue é baseada em LUTTINGER \& DICUM, 2006.
} 
a competir com a General Foods no controle do mercado americano. Em 1963, a Folgers foi comprada pela Procter \& Gamble (P\&G), enquanto a Hills Brothers foi comprada pela Nestlé, em 1985. No longo período que se estende de 1950 a 1989, a General Foods, a P\&G e a Nestlé, para citar algumas das grandes corporações, dedicaram maior parte dos seus investimentos em publicidade e no desenvolvimento de tecnologias que dessem maior consistência ao sabor dos cafés comercializados. A qualidade sensorial da bebida não era a prioridade das empresas no período, lembrando que foi também no período pós-guerra que surgiram uma série de bens destinados mais à "comodidade" do que à "qualidade", como as casas pré-fabricadas, os jantares de televisão ( $T V$ dinners), as meias de nylon e vários materiais plásticos. Esse movimento, também permeado por estratégias de tecnificação da produção, teve sérias implicações no que diz respeito ao sabor dos produtos. Nas palavras de Nina Luttinger e Gregory Dicum , autores do The Coffee Book (2006):

Assim que os cafés regionais foram transformados em marcas nacionais, as prioridades de seus produtores foram alteradas. As preferências locais de gosto [taste] tornaram-se menos importante e a consistência no preço, a embalagem e sabor [flavor] vieram à tona. A fim de amortecer os estoques mundiais de vários tipos de café, os torrefadores passaram a adotar misturas diversas que eles poderiam ajustar para manter o preço e sabor relativamente uniforme, mesmo quando as condições de oferta alterassem. Embora essa estratégia tenha alcançado uma consistência no café, isso se fez à custa de abandonar a diversidade de sabores e componentes que tinha sido característica das pequenas torrefadoras independentes. (LUTTINGER \& DICUM, 2006, pg. 135) 23

Os chamados blends foram as estratégias do mercado para unificar variedades de cafés que vinham de diferentes regiões do mundo, na tentativa de uniformizar as nuances de sabor e manter uma consistência ao longo do tempo, o chamado flavor profile de um produto industrial. ${ }^{24}$ Isso porque, nos Estados Unidos da segunda metade do século XX, prevalecia o consumo de "cafés de supermercado", cujo sabor era praticamente

23 “As regional coffees were turned into nationals brands, the priorities of their producers changed. Localized taste preferences became less important and consistency in price, packaging, and flavor came to the fore. In order to buffer against world supplies of various types of coffee, roasters adopted diversified blends that they could adjust to keep price and taste relatively uniform even as supply conditions changed. While this strategy did indeed achieve consistency, it did so at the price of forsaking the diversity of flavors and qualities that had been the hallmark of the small independent roasters."

24 Um exemplo de blend conhecido é o Mocha Java, composto por uma parcela Mocha (países árabes), de suave acidez e corpo leve, e por uma parcela Java (indonésia), carregado em corpo e com notas de sabor mais escuras, amargas. O resultado é um sabor equilibrado. 
indistinguível e deliberadamente homogeneizado pelas empresas. A partir dos anos 1960, os Estados Unidos experimentaram um crescimento vertiginoso do consumo de refrigerantes, que passaram a roubar parte da parcela de consumo de café. As sodas, ou os soft drinks em geral (sucos, chás gelados, refrigerantes), se demonstraram eficientes fornecedores de cafeína, o que preocupou a indústria do café. Além do que, os refrigerantes, gasosos e com alto teor de açúcar, tinham maior apelo para a população jovem, os chamados baby boomers, que iriam definir os padrões de consumo das décadas seguintes. Algumas tentativas foram feitas pela indústria do café para tentar minimizar esse impacto, mas o fato é que, nos Estados Unidos, o consumo de café declinou progressivamente dos anos 1960 aos anos 1990, em grande parte, pelo aumento da oferta de produtos similares e substitutos. ${ }^{25}$ Apesar da constante ameaça, as empresas raramente ousaram investir na diversificação sensorial do produto. A possibilidade de competição entra as marcas se dava mais no terreno da propaganda e da acessibilidade dos preços nos anos 1950, por exemplo, prevalecia a tradição da "xícara de café de 5 centavos" (LUTTINGER \& DICUM, 2006). Demorou bastante para o mercado consumidor americano gastar mais pelo valor de uma xícara em proveito da qualidade do produto. Na Itália, o hábito de se consumir café em locais públicos, mediante cafeterias especializadas na venda de espressos para o passante urbano, dificultou a uniformização do sabor do café pela indústria. Em geral, a qualidade também era superior nos países escandinavos, que possuem uma longa tradição de ênfase em cafés especiais, menos industrializados, mais aromáticos. Por exemplo, a marca líder de cafés de supermercado nos países nórdicos é a Gevalia (da Kraft), que nos Estados Unidos é qualificada dentro da categoria de cafés especiais e, portanto, limita-se ao nicho de consumo de luxo.

Em paralelo às transformações decorrentes da industrialização e da concentração monopolística da torrefação e da distribuição de cafés nos Estados Unidos, houve o desenvolvimento do mercado de cafés especiais. Durante as décadas 1950-1990, havia poucas empresas torrefadoras de pequeno porte para oferecer cafés de qualidade ao mercado americano - existiam algumas em Greenwich Village (NY), Little Italy (NY) e

25 Lembremos que, há mais de um século, os Estados Unidos permanece na posição de maior consumidor mundial de café per capita. Durante a Segunda Guerra Mundial, sua participação era $80 \%$ do total consumido no mundo (LUTTINGER \& DICUM, 2006). Hoje, sua participação é de $20 \%$ do total. 
Berkeley (CA). Em Berkeley, surgiu uma das primeiras cafeterias gourmets dos Estados Unidos, a Peet's Coffee \& Tea, fundada em 1966 por Alfred Peet. Holandês emigrado para os Estados Unidos, com experiência anterior na degustação de chás, Peet foi pioneiro na torrefação cuidadosa de grãos, promulgando um perfil de torra mais escura (dark roast blend), além de ter ajudado a disseminar a ideia de se apreciar variedades de café de diversas partes do mundo. ${ }^{26}$ Peet também foi o mentor de Jerry Baldwin, Zev Siegl e Gordon Bowker, que levaram sua técnica de torrefação para Seattle e fundaram a Starbucks, anos depois. Ironicamente, em 1984, a Starbucks comprou a Peet's. Em 1987, os sócios fundadores da Starbucks venderam sua participação na Starbucks para Howard Schulz, que depois virou CEO ${ }^{27}$ da empresa. A partir dos anos 1980, o segmento gourmet foi se destacando do café vendido a varejo pelas grandes marcas, primeiramente pela atmosfera que as cafeterias traziam:

Cafeterias fazem parte de uma ideia muito antiga, mas na paisagem consumista dos anos 1980 elas eram uma ruptura radical com a norma. Elas incentivavam o cliente a sair, a desperdiçar a tarde na rua, e isso sem gastar muito. Em uma paisagem de espaços públicos projetados para motivar as pessoas a comprar algo e depois ir embora (incluindo esses dispositivos manipuladores de restaurantes fast food com as cores projetadas para fazer você ficar com fome e as cadeiras projetadas para fazer você se sentir desconfortável), um espaço público suave com sofás e livros apontava para uma revisão radical da relação entre o consumidor e o varejista. Quando a Starbucks começou a vender bebidas de café em vez de apenas grãos torrados, Schulz e sua equipe percebeu essa necessidade imediatamente. (LUTTINGER \& DICUM, 2006, pg. 159) ${ }^{28}$

A Starbucks começou sua existência vendendo apenas grãos torrados e moídos para os apreciadores de café de Seattle, cidade que passou por um rápido período de expansão quando virou um centro de tecnologia na década de 1980. Lembremos que a Microsoft e a Amazon, junto com outras empresas informáticas, vieram de lá. Juntas, companhias de

26 MARSHALL, Carolyn. "Alfred H. Peet, 87, Dies; Leader of a Coffee Revolution". New York Times, September 32007.

27 Chief Executive Officer, diretor executivo.

28 "Cafés are a very old idea, but in the consumerist landscape of the 1980s they were a radical departure from the norm. They encouraged the costumer to hang out, to idle away the afternoon, and to do so without paying very much. In a landscape of public spaces designed to entice people to buy thing and then leave (including such frankly manipulative devices as fast food restaurants with colors designed to make you hungry and chairs designed to make you uncomfortable), a subdued public space with couches and books amounted to a radical revision of the consumer-retailer relationship. When Starbucks began to sell coffee drinks rather than just roasted beans, Schulz and his team noticed this need immediately." 
software, biotecnologia e internet criaram uma demanda por locais de encontro, simultaneamente voltados para o lazer e para o trabalho, nos quais os jovens trabalhadores da indústria tecnológica poderiam plugar seus laptops enquanto tomavam um cappuccino e conversavam com colegas de trabalho. Esse foi o terreno no qual a Starbucks cresceu, deixando de ser apenas uma vendedora de grãos torrados para amantes do café, segundo aquele estilo aprendido no Peet's de Berkeley, para tornar-se uma rede de cafeterias que oferece uma gama maior de bebidas (diferentes combinações de café, a maioria com leite, alguns chás) e algumas comidas prontas para levar. Quando começou, Starbucks era conhecida por oferecer grãos de torra mais escura, uma tendência que ela também absorveu do Peet's. Outras empresas também de Seattle, como a SBC Coffee e a Caravali, produziam cafés com torras mais claras, mais próximo do que hoje prevalece como regra no mercado gourmet. ${ }^{29}$ A Starbucks cresceu vertiginosamente nos anos 1990 e anos 2000; em 1984, abriu seu primeiro coffeebar no centro de Seattle, entrando no ramo dos serviços, das cafeterias; em 1987, ainda haviam apenas 17 lojas da Starbucks; em 1990, já chegava perto de 200 lojas; em 1998, já ultrapassava as 2.000 lojas; e hoje, possui mais de 15.000 lojas em um total de 50 países. Segundo os autores Craig Thompson e Zeunep Arsel (2004), a Starbucks, durante esse tempo, passou a ocupar a posição de um modelo cultural, ao lado de outras grandes marcas globais. Enquanto marca, fornece aos consumidores orientações de estilo de vida, ao mesmo tempo em que define o quadro de variações possíveis para os seus competidores a nível local, mediante "estruturas de diferenças comuns". Dentre as características da empresa, algumas tornaram-se parâmetros estéticos para o surgimento de novas cafeterias, como as seguintes características: decoração inspirada na arquitetura europeia; linguajar esotérico das bebidas, por exemplo, latte (café com leite); exibição de obras de arte visual; músicas de fundo (de estilo sofisticado, hip ou contracultural); grandes porções de muffins gourmet; mídia e jornais voltados para as artes, que podem ajudar a estimular conversas casuais entre os frequentadores; senso de mundo interconectado (worldliness), através da presença de mapas ou alusões às regiões

29 Para Umberto Bizzarri, dono da Torrefazione Italia, empresa que surgiu em Seattle no ano de 1986, o espresso da Starbucks tem gosto de queimado: "It's like burned coffee" (BEHR, 1992, pg. 241). Hoje, a Starbucks oferece pelos menos três variações de torra nos cafés embalados para levar: blonde, medium, dark. 
produtoras de café; por fim, uma visão nostálgica da comunidade (THOMPSON \& ARSEL, 2004). Além dessas questões, a autora Bobbi Bowman (2008) nos lembra que o consumidor regular da Starbucks possui um perfil destacável: ele é de classe média alta, branco e possui escolaridade universitária, o que nos ajuda a circunscrever em que meios circulam os padrões estéticos destacados acima.

Em 1988, as vendas da Starbucks totalizavam apenas \$10 milhões, contra uma indústria de varejo que faturava $\$ 5$ bilhões por ano, isso só nos Estados Unidos. Portanto, era difícil para os grandes atores do café imaginar a revolução que o mercado de cafés especiais iria causar na década seguinte. O que houve foi uma explosão de cafeterias e torrefadores artesanais de café. Como preocupação de mercado, o preço e a consistência foram deixados de lado, em seu lugar vieram a consideração pela origem, pela qualidade, pelo processo da torra e pelos métodos de cultivo do café. Consequentemente, veio uma reestruturação da forma de apresentação dos produtos e uma diversidade de modos de preparo se estendeu pelo mercado, abarcando das variedades de café oferecidas à espessura da moagem dos grãos. Aos poucos, a qualidade introjetou-se na indústria como um todo. Grandes empresas como a Starbucks ajudaram a educar os consumidores nessa direção, na forma de percepção das qualidades sutis do produto, mesmo quando este é industrialmente tratado. Apesar de que a porta de entrada não era exatamente gourmet. O café mais vendido naquela época era o cappuccino, que era feito com bastante leite vaporizado e geralmente acrescentado de canela ou chocolate, as vezes ainda por cima adoçado. Outro tipo bastante pedido era o latte, que leva cerca de três vezes mais leite vaporizado, resultando em um sabor mais suave de café. Era de se esperar que aos poucos alguns consumidores iriam migrar para formas mais puras de apreciação do café: primeiro, cappuccinos básicos, depois cappuccinos com dupla dose de café, seguidos de espressos puros e, por fim, ristrettos.

Mas os cafés mais apreciados em Seattle, que se propagaram pelo mundo com a Starbucks, continuaram sendo bebidas de café preparadas com leite. Apenas para poucos a preferência mudou. Em medida contida, o paladar açucarado dos baby boomers, criados com candies e refrigerantes, foi habituando-se ao amargor e à acidez características do café. Nos Estados Unidos, o espresso puro já havia tido uma pequena popularidade durante 
os anos 1960, no entorno dos centros universitários. Sua ressurgência nos anos 1990, no entanto, teve proporções nacionais e atingiu diversos segmentos de classe, não apenas as elites. ${ }^{30}$ Em termos sensoriais, a tendência prevaleceu em direção ao escurecimento das torras, agora mais próxima do perfil italiano e francês..$^{31} \mathrm{O}$ sabor amargo mais acentuado, potencializado pelo escurecimento da torra, se propagou junto com o estilo de vida jovem e descontraído das novas cafeterias, que misturavam o ócio lúdico do ambiente permeado por sofás, as pausas de relaxamento em horários comerciais e o frêmite da vida urbana veloz, materializada nas bebidas e snacks prontos para levar (to-go coffee). Junto com Seattle, a California foi o berço das cafeterias que materializavam esse estilo de vida descontraído, gourmet hippie chic, onde locais de encontro e prazer gastronômico se tornaram também vias de acesso para um senso de comunidade perdido. ${ }^{32}$

Também os signos de origem do café (ao estilo francês das appellations d'origine contrôlée) foram popularizados nos anos 1990, a Starbucks sendo uma empresa que se orgulhava por ofertar cafés provenientes de diferentes regiões do mundo. Já a popularização dos signos referentes à sustentabilidade do café é mais recente, consolidouse na virada para os anos 2000. Em 1999, no espírito dos protestos anti-globalização que aconteceram em Seattle, durante a reunião da WTO (World Trade Organization), críticas também foram feitas ao modelo corporativista da Starbucks, na medida em que circulavam notícias sobre as situações paupérrimas dos produtores de café em países como a Nicarágua e a Guatemala, que também exportavam grãos para a empresa norte-americana. Como consequência dos protestos, a empresa passou a vender grãos certificados como Fair Trade (selo que qualifica o comércio justo para os produtores). Em 2000, críticas oriundas das associações de agricultura orgânica também fizeram a empresa adotar o leite orgânico, caso o mesmo seja especificado pelo cliente na hora da compra. De um modo geral, o consumo organizado dos anos 2000, fortalecido pelas redes informáticas de troca de

30 Thompson e Arsel (2004) argumentam que a Starbucks transformou o café gourmet de um símbolo de status para os yuppies em um bem de consumo mainstream (generalizado).

31 A concentração de sabor também foi alterada. Na década de 1930, a proporção era de 45 xícaras para 1 pound de café torrado; nos anos 1990, a tendência era de 100 xícaras para 1 pound de café. O segmento de cafeterias gourmets, junto com a proliferação da modalidade espresso, resgatou a maior concentração de sabor (amargor, acidez) que prevalecia no começo do século.

32 O próprio Howard Schulz, CEO da Starbucks, costuma usar a expressão third place, retirada do sociólogo Ray Oldenburg, para se referir a cafeteria como um espaço intermediário: fora da casa e fora do trabalho. 
informação, contribuiu para aumentar a pressão sobre o controle de qualidade e a aceitação dos selos de responsabilidade por parte das grandes empresas que controlam o mercado de varejo de café torrado. Sabe-se que o Brasil é o país com maior número de fazendas de café certificadas quanto à sustentabilidade e ao comércio justo. ${ }^{33}$ No entanto, é importante frisar que o mercado de cafés especiais, preocupado com o componente sensorial da bebida, permanece muito maior do que o mercado de cafés sustentáveis, esse último preocupado puramente com questões sociais e ambientais:

A indústria do café sustentável começou como um nicho dentro de um nicho. Mas na medida em que o mercado de cafés especiais cresceu, o café tornouse um pioneiro em termos de sustentabilidade na indústria de alimentos - e até mesmo na cultura de consumo como um todo. (LUTTINGER \& DICUM, 2006, pg. 188) $)^{34}$

Se hoje a Starbucks tem 21.536 lojas (meados de 2015), há um bom tempo ela não pode mais ser considerada uma representante do mercado de torrefadores artesanais. Algumas empresas de torrefação de café de baixa escala ganharam relevância do final dos anos 1990 para cá. São elas a Intelligentsia Coffee \& Tea, a Stumptown Coffee Roasters e a Counter Coffee Culture, consideradas as "Três Grandes" (Big Three) da terceira onda do café. A elas veio se juntar a Blue Bottle Coffee, em 2002, sendo hoje a maior das quatro, com 18 cafeterias espalhadas pelos Estados Unidos e agora também em Tokyo. Lembrando que a denominação terceira onda aplica-se àquelas empresas que possuem uma relação mais próxima com os produtores de café, marcada pela fornecimento direto de cafés verdes (ou seja, sem grandes intermediários), a maioria sendo composta por proprietários de cafeterias independentes que também funcionam como micro-torrefadoras. O crítico de comida Jonathan Gold define da seguinte maneira a terceira onda:

A primeira onda da cultura americana de café foi provavelmente a onda do século XIX que colocava Folgers em cada mesa, a segunda foi a da proliferação, começando na década de 1960 com Peet's e movendo-se para o grande decaf latte da Starbucks, das bebidas de café expresso e do café rotulado por regiões. Estamos agora na terceira onda, a onda do conhecimento técnico de café [connoisseurship], em que os grãos são

33 Redação Folha de São Paulo. "Café”. Folha de São Paulo, Informe Publicitário, 17 de nov. 2014.

34 "The sustainable coffee industry began as a niche within a niche. But as the specialty market has grown, coffee has become a pioneer in sustainability within the food industry - and even within consumer culture as a whole." 
rastreados a partir das fazendas de origem em vez de países, e em que a torrefação é sobre trazer à tona, em vez de queimar, as características únicas de cada grão; o sabor agora é limpo, duro e puro. (GOLD, 2008) 35

É interessante traçar um perfil das torrefadoras artesanais norte-americanas que ganharam reconhecimento em meio ao movimento da terceira onda. A Intelligentsia Coffee \& Tea foi fundada em 1995 por Doug Zell e Emily Mange na cidade de Chicago. A intenção de vender café torrado fresco, não envelhecido, começou com uma máquina de torrefação que suportava apenas 12 quilos de grão. Hoje eles fornecem grãos para vários cafés e restaurantes de Chicago, além de possuírem oito lojas próprias (espresso-bars), em Chicago, Los Angeles e Nova York. ${ }^{36}$ Os grãos verdes são comprados diretamente de produtores da América Central, América do Sul, Leste da África e Etiópia. Um dos baristas empregados pela Intelligentsia, Michael Phillips, chegou a ganhar campeonatos de barista enquanto trabalhava para a empresa. Também em 1995, foi fundada a Counter Culture Coffee, em Durham (North Carolina), pelos sócios Brett Smith e Fred Houk. O intuito inicial era fornecer blends de café para os restaurantes locais. Hoje a empresa comercializa seleções sazonais de cafés importados de quatro continentes, América, África, Ásia e Oceania. Uma das propostas da empresa é também oferecer programas educacionais focados na sustentabilidade e nas técnicas de preparo da bebida. Os centro de treinamento da Counter Culture Coffee, que não funcionam como lojas de venda a varejo dos grãos, são localizados em Asheville, Atlanta, Boston, Chicago, Durham (NC), Nova York, Philadelphia e Washington (DC); no total, são oito centros. ${ }^{37}$ No site da empresa, lemos o compromisso com o frescor da torra, que também é característica da terceira onda: "nós também torramos o café a pedido, e o café é torrado, embalado e enviado no mesmo dia". ${ }^{38}$

35 "The first wave of American coffee culture was probably the 19th-century surge that put Folgers on every table, and the second was the proliferation, starting in the 1960s at Peet's and moving smartly through the Starbucks grande decaf latte, of espresso drinks and regionally labeled coffee. We are now in the third wave of coffee connoisseurship, where beans are sourced from farms instead of countries, roasting is about bringing out rather than incinerating the unique characteristics of each bean, and the flavor is clean and hard and pure." (GOLD, Jonathan. "La Mill: The Latest Buzz". LA Weekly, March 12, 2008)

36 Wikipedia. "Intelligentsia Coffee \& Tea".

37 Wikipedia. "Counter Culture Coffee".

38 Site da Counter Culture Coffee. Disponível em: <https://counterculturecoffee.com/contact/about-us>. Acesso em: 07 maio 2015. 
A Stumptown Coffee Roasters inaugurou sua primeira loja em 1999, Portland (Oregon). ${ }^{39}$ Seu fundador, Duane Sorenson, virou uma espécie de ícone do meio de cafés especiais, pela convicção com a qual fala da qualidade dos seus grãos e também pelo seu estilo de ser, um homem alto, barrigudo e barbado que usa bastante a palavra "fuck" nas frases. ${ }^{40}$ Ao invés de misturar vários lotes de grão e fazer blends, Sorenson prefere vender micro-lotes que vem de apenas uma fazenda (single-origin coffees). Os sacos são embalados com o nome da fazenda onde o grão foi cultivado e com o nome da variedade de grão (ex: Finca El Puenta - Bourbon). Sorenson começou vendendo seu café por atacado para clientes que ele mesmo entregava em um vagão da Ford. A primeira máquina torrefadora comprada por Sorenson foi uma Probat de ferro fundido, fabricada nos anos 1920, que tinha capacidade para $5 \mathrm{~kg}$. Atualmente, a Stumptown já cresceu bastante e possui unidades de torrefação em quatro cidades norte-americanas, mais 10 lojas (coffee bars) em Portland, Seattle, Nova York e Los Angeles. ${ }^{41}$ Em 2011, a empresa também passou a vender café gelado engarrafado, que distribui para todo os Estados Unidos. Duane Sorenson também ficou conhecido por pagar preços altos pelos grãos verdes de café que encontra na suas expedições aos países produtores — três a quatro vezes o preço do fair trade. ${ }^{42}$ Também no relacionamento com os funcionários a Stumptown se destaca: o proprietário já chegou a oferecer massagista em tempo integral para os funcionários dos estabelecimentos, além de pagar a gravação de um álbum com as bandas dos empregados. Quando a empresa foi vendida para uma firma de investidores de Nova York (que passaram a deter $90 \%$ da empresa), vários especialistas lamentaram o fato, alegando que a indústria corporativa já havia engolido empresas torrefadoras promissoras (a Torrefazione Italia e a Seattle's Best Coffee, ambas adquiridas pela Starbucks, e a Green Mountain, adquirida pela Coca-Cola),

39 O nome da empresa, Stumptown, foi dado em homenagem à tradição que a cidade tem no mercado madeireiro. Stump significado cepo, toco, a parte de uma árvore cortada que permanece enraizada.

40 ALTMAN, Mara. “The Messiah Hails From Portland”. New York Magazine, April, 2009.

41 Wikipedia. "Stumptown Coffee Roasters".

42 Em 2004, Sorenson pagou o maior preço já visto, até então, pelo quilo de grão para uma única fazenda, isso em dois países latino americanos. Para a fazenda Los Delirios (Nicarágua) pagou \$12 dólares pelo pound (10 vezes o preço do Fair Trade comum) e \$21 dólares pela libra (pound) do Esmerelda Especiale do Panamá (20 vezes o preço do Fair Trade comum). Na degustação desse último café, Sorensen o descreveu como tendo "notas de blueberries, bergamota e crème brûlée". Cf. "Unwrapped". Willamette Week, 2004. Lembrando que a libra (pound) comercializado nas lojas dessas torrefadoras, a Stumptown, a Intelligentsia e a Counter Culture, por exemplo, custa em média \$27 o pacote regular. No entanto, esses lotes especiais, que possuem notas sensoriais mais distintivas, são mais caros, podendo custar de $\$ 50$ a $\$ 80$ a libra (pound). 
o que havia gerado efeitos negativos na qualidade do produto. ${ }^{43}$ Doravante, as três cafeterias juntas, a Stumptown, a Counter Culture e a Intelligentsia, compõem um exemplo da reorganização do mercado de cafés, ao mesmo tempo em que condensam as características de um modelo cultural que passa a ser replicado em outros países. Desde que o termo specialty coffee foi forjado por Erna Knutsen em 1978, o mercado de cafés ainda não havia se organizado para suprir essa demanda por produtos com maior densidade de conhecimento técnico e sensorial.

Em um artigo intitulado "A ascensão dos cafés yuppies e a reimaginação da classe nos Estados Unidos”, o antropólogo William Roseberry (1996) apresenta uma convincente análise da ascensão do consumo de cafés gourmet no Estados Unidos. Em inglês, os cafés mais sofisticados são chamados pelo nome de specialty coffees, o uso dessa nomenclatura teve certa influência sobre o mercado brasileiro, na medida em que temos os chamados cafés especiais. De uma forma geral, preferi deixar o termo gourmet em evidência para facilitar a aproximação com as tendências observadas em outros campos da gastronomia. Segundo Roseberry (1996), o período do começo do século XX foi marcado por uma uniformização (standardization) do café, movimento que está em consonância ao advento dos supermercados nas grandes cidades americanas - e, como vimos acima, a presença crescente de alimentos “enlatados". Ora, sabe-se que o café daquela época era vendido em latas para os supermercados por grandes empresas de torrefação, portanto, havia pouco espaço para pequenos torrefadores e pequenos distribuidores. ${ }^{44}$ Isso implicava que não havia grande variedade de marcas e tipos de café — nas palavras de Roseberry, ali o café servia como mais um dos alimentos base, um proletarian hunger killer. No entanto, esse processo se inverteu nos anos 1980. Desde os anos 1960 experimentava-se uma diminuição a longo prazo no consumo de café pelo americano médio. Essa tendência veio a piorar em 1975 quando uma geada na produção brasileira provocou um aumento generalizado dos

43 CARMICHAEL, Todd. "The End of Stumptown, America's Hippest Coffee Brand". Esquire, May 31 2011.

44 Caberia aqui fazer uma breve apresentação da cadeia produtiva do café. É importante salientar o papel crucial desempenhado pelos torrefadores na cadeia do café. Para se ter uma noção, a Starbucks era, de início, apenas uma empresa de torrefação (roaster). Para facilitar a visualização, montarei um esboço dos atores envolvidos na comércio do café seguindo a direção produção-consumo:

Plantadores -» Comerciantes (Firmas de exportação, Importadores, Armazéns de estocagem) -» Torrefadores

-» Distribuidores -» Varejistas (revendedores) -» Baristas/funcionários -» Consumidores 
preços. Foi aí que surgiu um estímulo para a inovação no mercado de cafés, pois o café "de qualidade" parou de custar três vezes mais do que o café de supermercado. Nesse sentido, enquanto encarecia o café de tipo básico - o enlatado proletarian hunger killer -, diminuia a diferença de seu preço em relação aos poucos rótulos sofisticados que existiam.

Como consequência, Roseberry (1996) argumenta que foi aumentando a demanda por esses cafés de maior qualidade, e assim novas empresas torrefadoras começaram a surgir e distribuir seus cafés para outros revendedores. A Starbucks, por exemplo, surgiu em 1971. Soma-se a isso o fato de que uma revolução no transporte internacional - o advento de containers - diminui o tempo de chegada dos grãos verdes das regiões produtoras, facilitando o planejamento e a negociação exportação-importação. Não só; também desenvolveram-se técnicas de embalagem a vácuo que melhoraram as condições de conservação da qualidade do café. Tudo isso resultou no boom gourmet dos anos 1980, que junto com a proliferação das gourmet shops disseminou também uma contra-cultura anti industrialização alimentar, ou seja, o culto do alimento "natural", "integral" e "fresco" - o que já havia sido defendido nos pequenos nichos do movimento hippie. Segundo Roseberry, foram os novos torrefadores e distribuidores do café e não gigantes como a General Foods, a Procter and Gamble e a Nestlé que, impulsionados pela onda dos cafés especiais, se tornaram verdadeiros agentes dessa reorganização do mercado americano. ${ }^{45}$ Nesse ímpeto, também os novos distribuidores de café procuraram angariar novas fontes de fornecimento do grão, enfatizando a espécie arábica e desenfatizando a robusta - a robusta em sua maior parte é produzida pelos países da África, sendo Uganda e Costa do Marfim os maiores produtores. ${ }^{46}$ Para Roseberry, essa questão geopolítica dos tipos de grão (arabica $\mathrm{x}$ robusta) é bastante importante, pois o declínio da preferência pelo robusta gera efeitos dramáticos nas situações de trabalho dos países produtores africanos. Até 1989 vigia um acordo - o International Coffee Agreement (ICA) - que definia cotas de venda para os países produtores e que, dessa forma, assegurava uma repartição dos perigos de uma eventual flutuação nos preços e na demanda. Por divergências na ocasião de

\footnotetext{
45 Foi apenas em 1986 que a General Foods e a $A \& P$ (a rede de supermercados The Great Atlantic \& Pacific Tea Company) introduziram suas versões industriais dos cafés especiais (specialty) nos supermercados (ROSEBERRY, pg. 768).

46 Com entrada tardia no mercado de cafés, o Vietnã é hoje o maior produtor mundial da variedade robusta.
} 
renovação do acordo, o ICA foi suspenso, o que provocou uma situação de livre-mercado do café pela primeira vez em décadas. Pouca atenção se dirige a esse aspecto, mas o fato é que algumas economias africanas foram devastadas. ${ }^{47}$ Roseberry, demonstrando seu veio marxista, lamenta a situação:

O livre mercado aumentou imensamente a flexibilidade dos comerciantes de café e 'periferalizou' o trabalho dos plantadores de café de uma forma direta e imediata. Minha liberdade de escolha nas delis ${ }^{*}$ do outro lado da rua ou na loja gourmet a alguns quarteirões de distância está implicada com a liberdade do comerciante de café de cortar o fornecimento (e, portanto, o rendimento do trabalhador) de Uganda ou da Costa do Marfim, digamos. Na medida em que os negociantes de café têm sido bem sucedidos na criação de novos estilos, de modo que eu pense que esteja bebendo o café de um lugar especial, na verdade, o café não precisa ter qualquer ligação real com esse lugar, eu não vou estar ciente dos processos de conexão e desconexão dos quais estou participando. Trata-se da 'bebida do capitalismo norteamericano', de fato! (ROSEBERRY, 1996, pg. 772-773) $)^{48}$

Além dessa geopolítica dos países produtores e das condições de trabalho envolvidas na larga cadeia produtiva do café, que vai da plantação ao copo do consumidor, temos uma outra dimensão geopolítica que é menos abordada nas ciências sociais. Trata-se da questão do surgimento e da circulação de sabores. Ou seja, a disseminação de cafés e cafeterias gourmets, junto com a disseminação correspondente da capacidade de

47 Ruanda foi um dos países mais afetados, pois a produção de café representava $80 \%$ do total das exportações do país no começo dos anos 1990. Evidentemente que o Brasil já tinha deixado de ser uma economia estreitamente dependente da exportação de café; em 2003, aparece na vigésima posição das listas dos países mais dependentes do café, com base em dados da FAO, WTO e CIA (LUTTINGER \& DICUM, 2006, pg. 104). Em 1989, o café já tinha reduzido sua participação no total das exportações a mero 5\%, menos de 1\% do total do Produto Nacional Bruto (PNB). No entanto, para se ter uma ideia do impacto no setor, só em 1993, mais de 800 milhões de cafezais foram arrancados no país, em consequência da baixa dos preços desencadeada pela situação de livre-mercado (LUTTINGER \& DICUM, 2006). Quando as geadas de 1994 fizeram o preço internacional disparar, novos atores entraram no mercado. No entanto, a crise persistiu e, como consequência, levou a uma maior mecanização da produção e à substituição dos contingentes de trabalhadores braçais pelo uso de equipamentos que tornaram as fazendas intensivas em uso de capital, o que melhorou consideravelmente os custos de produção, junto com o aumento da produção de robusta, a espécie mais fácil de se produzir. Mesmo assim, as mudanças foram insuficientes para enfrentar os percalços. Em 1999, a superprodução mundial levou a uma queda ainda maior dos preços, trazendo uma crise grave para o setor. Em 2001, o café atingiu o menor preço da sua história no comércio internacional, custando 42 centavos de dólar a libra (0.45359237 quilogramas).

* Pequenos mercados.

48 "The free market vastly increased the flexibility of coffee traders and 'peripheralized' the labor of coffee growners in a direct and immediate way. My freedom to choose in the deli across the street or the gourmet shop a few blocks away is implicated with the coffee trader;s freedom to cut off the supply (and therefore the product of the laborer" from, say, Uganda or the Ivory Coast. To the extent that 'coffeemen' have been successful in creating styles, so that I think I am drinking coffee from a particular place but the coffee need not have any actual association with that place, I will not even be aware of the processes of connection and disconnection in which I am participating. 'The beverage of U.S. Capitalism,' indeed!' 
apreciação da "qualidade" do café, mediante a justaposição de tipos e texturas diversas, gera efeitos na hierarquia dos sabores. Sabemos que o café do trabalhador - o café como proletarian hunger killer - era, de uma forma geral, bastante adoçado. Em sua função gastronômica historicamente situada pelo mercado de produtos de massa e pela ideia da "comodidade", as propriedades gustativas do café não cumpriam tamanha relevância como passaram a ter como quando do então surgimento de cafés gourmets e de cafeterias especializadas no manejo desses cafés. Nesse momento, surge um novo tipo de consumidor. Este passa a obliterar progressivamente o uso do açúcar em favor da melhor apreciação das características organolépticas do café em si. Como resultado, podemos perceber uma crescente valorização da experiência gustativa do "amargor" e da "acidez" desde os anos 1980 aos dias de hoje. No Brasil, o "amargo" apenas ganha tamanha relevância social e técnica, isso nos circuitos interessados na apreciação estética do café, na primeira década do século XXI para cá, com a proliferação das cafeterias especializadas nas principais metrópoles brasileiras. Podemos qualificar tal processo como implicando uma "geopolítica dos sabores". Será importante relacionar tais mudanças em matéria de preferência gustativa das elites, que aos poucos se estende a outros estratos sociais, com a importância que o açúcar teve na formação da dieta brasileira, em fundamental acordo com a posição de economia do açúcar, que teve seu apogeu no Brasil Colônia, entre 1570 e 1650.

Durante décadas, o Brasil se preocupava apenas com a qualidade do produto do tipo exportação. A partir dos anos 80, algumas iniciativas foram criadas pela Associação Brasileira da Indústria do Café (ABIC) para melhorar a qualidade do café comercializado no mercado interno. O selo de pureza, por exemplo, criado em 1989, garante que a amostra seja composta apenas por grãos de café, já que pedaços de galho e até mesmo pedras podem estar misturados aos grãos comercializados. ${ }^{49}$ Os avanços mais significativos, no entanto, datam dos anos 2000 para cá. Em 2004, foi criado o Programa de Qualidade do

49 Segundo reportagem, ele foi a primeira certificação da área de alimentos e bebidas no mundo. "Sua criação foi uma resposta da ABIC aos consumidores que, em meados da década de 1980, vinham abandonando o hábito de consumir café por acreditar que o produto puro era exportado, e no Brasil só se consumia bebida de baixa qualidade, impura ou com misturas" (Redação Folha de São Paulo. "Café". Folha de São Paulo, Informe Publicitário, 17 de nov. 2014) 
Café (PQC), um programa de certificação para o café torrado ${ }^{50}$ que se adequa aos parâmetros recomendados pela ABIC. Para obter a certificação, as empresas são auditadas por técnicos credenciados pela $\mathrm{ABIC}$ e, dentre os critérios avaliados, há a montagem do "Perfil do Sabor", que identifica sete características do produto: bebida, torração, moagem, sabor, corpo, aroma e tipo de café. Assim, a qualidade da bebida é avaliada sensorialmente por provadores credenciados e é dada uma nota de 0 a 10. Em 2006, o PQC se segmenta nas seguintes categorias: tradicional, superior e gourmet. O café que receber de 4,5 a 6 é qualificado como tradicional, superior aquele que receber de 6 a 7,3, e gourmet de 7,3 a 10. Essa classificação também envolve a questão do tipo de café, já que o tradicional pode ser formado por blends de cafés arábica e robusta, enquanto as outras categorias devem ser formadas apenas por cafés da espécie arábica.

Segundo o Guia Prático do Programa de Qualidade do Café (PQC), fornecido pelo site da ABIC, o objetivo final do programa é a "melhoria da qualidade do produto e satisfação do consumidor". Tendo como foco a formação da consciência do consumidor em relação à qualidade do produto comprado, o guia chega a dizer que o PQC “é também um programa de Educação do Consumidor para o consumo do café: melhor informado, consome mais e busca produtos com melhor valor agregado e boa relação custo-benefício". Não seria inapropriado dizer que essa busca de qualidade pela indústria, motivada pela "satisfação do consumidor", levou a uma proliferação do "valor agregado" do café ao criar nichos de consumo em que se comercializam os cafés com certificações e notas sensoriais mais altas.

50 São avaliados os cafés torrados moídos e os cafés torrados em grão. O grão verde não é avaliado. 
Figura 6 - O perfil do sabor e o selo de qualidade gourmet

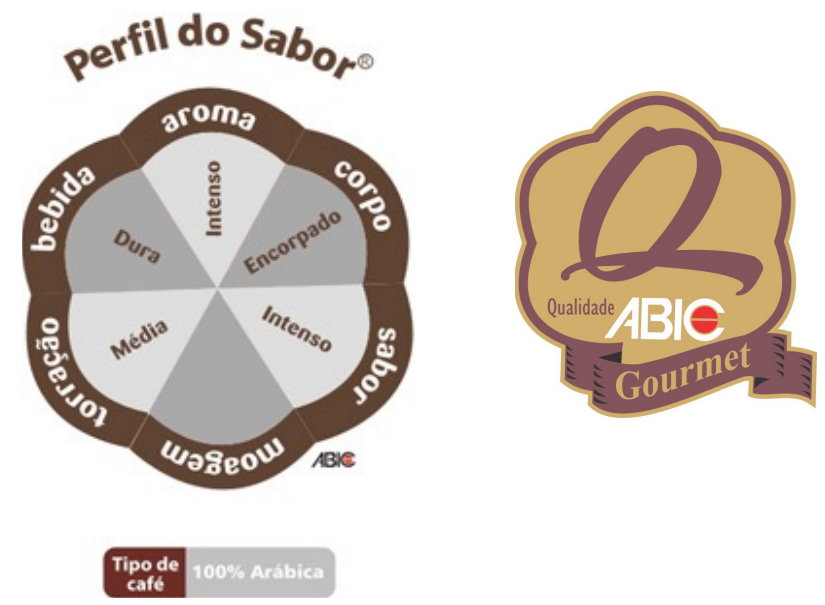

Fonte: site da $\mathrm{ABIC}^{51}$

Inspirada na SCAA (Specialty Coffee Association of America), surgiu a Associação Brasileira de Cafés Especiais (BSCA) em 1991, instituição que também emite certificados de qualidade. Diferentemente da $\mathrm{ABIC}$, na BSCA não há diferentes categorias de qualidade definidas pelos diferentes patamares de nota sensorial. O que há é uma série de critérios que uma amostra de café enviada para a BSCA precisa cumprir para obter o certificado único. Segundo o site da associação, a BSCA codificará a amostra recebida e enviará $200 \mathrm{~g}$ a 3 classificadores (escolhidos por sorteio dentre o quadro de classificadores da BSCA) e ao responsável técnico da BSCA. A avaliação dos grãos torrados e moídos é feita pelos mesmos classificadores numa pontuação de 1 a 8 para cada um dos seguintes aspectos: bebida limpa, doçura, acidez, corpo, sabor, gosto remanescente e balanço geral, subtraindose os defeitos e somando 36. Para ser certificado o café deverá obter pontuação maior ou igual a 80 e nenhum parâmetro igual a zero. A certificação é feita por lote e, portanto, é repassada do produtor para o comprador do lote de café.

51 Disponível em: <http://www.abic.com.br>. Acesso em: 25 maio 2015. 
Figura 7 - O selo de qualidade da BSCA

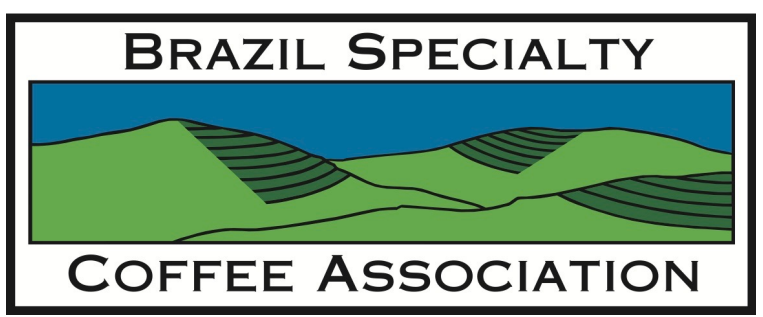

Fonte: site da $\mathrm{BSCA}^{52}$

Desde 2009, a associação BSCA possui uma parceria com a Apex (Agência Brasileira de Promoção de Exportações e Investimentos). Juntas, desenvolveram o projeto setorial Brazilian Specialty and Sustainable Coffees, que tem o objetivo de promover no exterior a imagem do Brasil como marca de qualidade no setor de cafés especiais, vendidos verdes. Com a ajuda da empresa contratada Place Branding, desenvolveram o conceito "Brazil. The Coffee Nation". ${ }^{53}$ Segundo o gestor do projeto na Apex-Brasil, Cláudio Borges, "essa marca, no contexto da estratégia de branding, resume os atributos positivos dos nossos cafés especiais e vai posicionar o País muito além do posto que já ocupa de maior produtor e exportador mundial, para ser reconhecido também como origem de produtos high end, que já estão presentes nos mais sofisticados e exigentes centros de consumo. Neste momento e com esse projeto, o Brasil se posiciona perante o mercado e deixa de ser posicionado por ele e pela concorrência". ${ }^{54}$ Sabemos que o Brasil é o maior exportador de grãos verdes de café do mundo. No entanto, seu nome nem aparece nas listas dos grandes exportadores de café torrado. Quem detém as primeiras posições no ranking de maior exportação de café torrado são a Suíça, a Itália e a Alemanha, respectivamente. Há tentativas recentes para melhorar as exportações brasileiras de café torrado, uma delas sendo o convênio entre a Apex e a ABIC que, desde 2002, por meio do PSI (Projeto Setorial Integrado de Promoção à Exportação de Cafés Industrializados), procuram juntas incentivar a exportação regular de cafés industrializados (torrado em grão e torrado e moído, ambos com marca brasileira). Enquanto o projeto setorial da parceria Apex-BSCA é

52 Disponível em: <http://bsca.com.br>. Acesso em: 25 maio 2015.

53 Cf. video da campanha no youtube.

54 Notícias BSCA. "BSCA inicia uma nova história para os cafés especiais do Brasil". Publicada em 16 de Abril de 2015. Disponível em: <http://bsca.com.br/noticias.php>. Acesso em: 25 maio 2015. 
dirigido ao segmento de cafés especiais, mediante a exportação de grãos verdes de alta qualidade, o projeto setorial da Apex-Abic está preocupado em melhorar a posição do Brasil nas listas de exportação do grão torrado, portanto, industrializado.

Gráfico 2 - O ranking dos maiores exportadores de café torrado, 2013

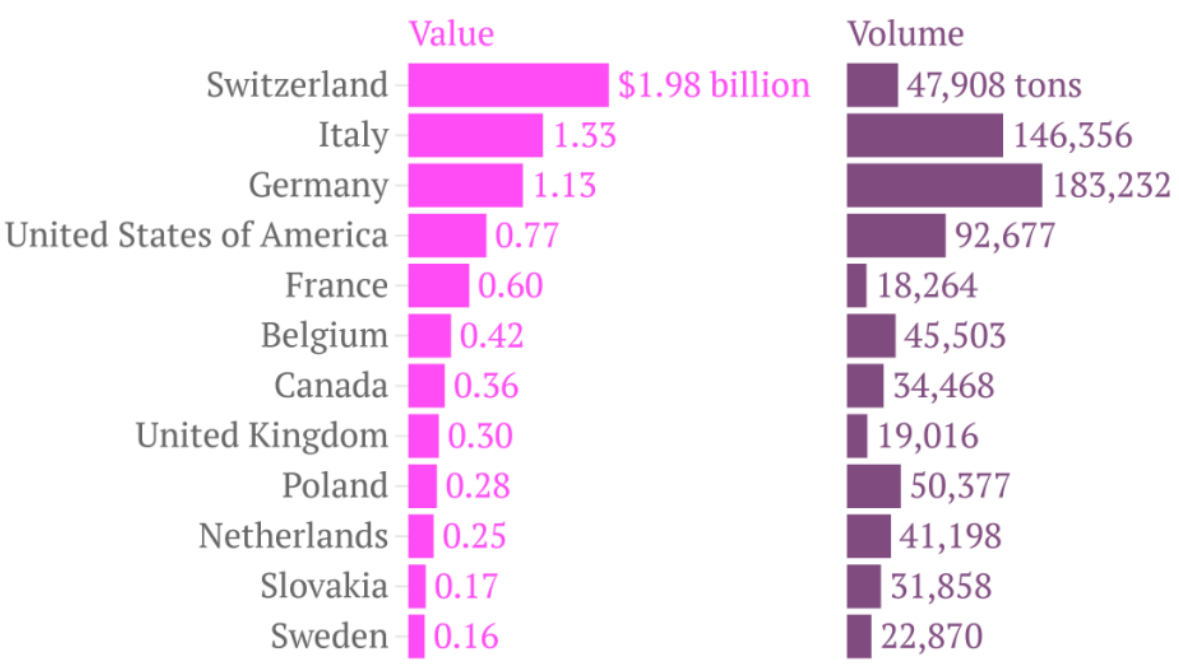

Fonte: site Quartz, elaborado a partir de dados do International Trade Centre 55

Diversos comentadores enfatizam a necessidade de se pensar melhor a exportação do "café com valor agregado". ${ }^{56}$ A esse respeito, é necessário dizer que há algumas maneiras de se agregar valor na exportação de café. Uma delas é aumentar a participação dos produtos com certificados de qualidade ABIC ou BSCA. Outra forma é por meio das medidas de promoção e marketing - o que já está sendo feito pelos projetos setoriais citados. No geral, a medida mais efetiva, no entanto, seria aumentar a exportação total de café torrado e moído (T\&M), que é uma forma de agregar valor com mais baixo investimento. Segundo uma reportagem no site de notícias Mark Café, essa não é uma saída tão fácil, em razão das barreiras comerciais:

55 Disponível em: <http://qz.com>. Acesso: 21 maio 2015.

56 Conferir, por exemplo, reportagem "É preciso exportar café com maior valor agregado", do site da Mark Coffee Magazine, uma revista eletrônica, que possui a missão de disseminar o conhecimento adquirido sobre o grão. A mesma reportagem define da seguinte forma a questão do valor agregado: "isto significa incorporar ao produto mais serviços e/ou insumos, de tal forma que os preços alcançados no mercado externo sejam superiores aos atualmente auferidos, pela exportação do café em grão". 
Como o processo de torrefação e moagem é tecnologicamente simples, as barreiras para ampliação das exportações de café T\&M não são tecnológicas, mas comerciais Estima-se que, dado o atual parque industrial existente no país, poder-se-ia exportar perto de 4 milhões de sacas de café T\&M. Isto demonstra que a exportação de café T\&M esbarra não apenas em esforço individual de produtores, mas em barreiras comerciais poderosas, levantadas pelas empresas transnacionais que atuam no segmento de reexportação de café verde e T\&M. Estas barreiras só poderão ser retiradas a partir de políticas comerciais, que dependem também dos estados nacionais e não apenas de esforço dos empresários do setor. (Site do Mark Café) ${ }^{57}$

A exportação de café já foi um dos principais fatores das políticas econômicas do país, o que era patente até a década de 1950. Hoje, no total das exportações do Agronegócio brasileiro, o café ocupa a quinta posição, atrás da soja, da carne, do complexo sucroalcooleiro e dos produtos florestais. ${ }^{58} \mathrm{O}$ Brasil responde por cerca de $30 \%$ das exportações mundiais de café, quase um terço do mercado mundial. Isso significa que a cada três xícaras de café consumidas no mundo, pode-se dizer que uma foi feita a partir de grãos brasileiros. Vale lembrar que, no mundo, se consome mais de 2,25 bilhões de xícaras de café por dia. Essa visão da participação brasileira é apenas um lado da história. A maior parte do montante exportado pelo Brasil vai na forma de grão verde e, portanto, possui baixo valor agregado; o torrado e moído representa apenas $0,1 \%$ das exportações brasileiras de café. Sendo o segundo maior consumidor de café do mundo, muitas vezes o Brasil exporta o grão verde para depois importar o grão torrado de outros países, o que para alguns analistas constitui uma irracionalidade do ponto de vista econômico, resultado da falta de orquestração e da organização dos interesses no mercado externo. Por exemplo, de Janeiro a Novembro de 2014, o Brasil importou US\$ 44,1 milhões de café torrado, porém as exportações no mesmo período foram de US\$ 11,2 milhões, o que segundo o Ministério do Desenvolvimento, Indústria e Comércio Exterior (Mdic) equivale a um saldo negativo de US\$ 33 milhões na balança comercial, segundo o Relatório Internacional de Tendências do Café, publicado em 02 de Março de 2015 pelo Bureau de Inteligência

57 Disponível em: <http://www.markcafe.com.br>. Acesso em: 24 ago 2015.

58 Em 2014, o café teve uma participação de 6,9\% no total das receitas do agronegócio brasileiro, com mais de 200 firmas exportadoras de café. O ranking foi produzido com base na receita em US\$ e foi acessado no site da ABIC, seção Estatísticas. Fonte original: AgroStat Brasil a partir de dados da SECEX/MIDIC. 
Competitiva do Café. ${ }^{59}$ Até mesmo o diretor da SNA (Sociedade Nacional de Agricultura), Ruy Barreto Filho, declarou, em 2012, que “o Brasil ainda não possui uma política de exportação de café com valor agregado". ${ }^{60}$ Para ele, o país precisa deixar de ser apenas produtor e exportador de commodities, o que pode ser feito através da comercialização do café já blendado e industrializado. Enquanto o mercado externo não dá muito espaço para o Brasil na comercialização de produtos de café com maior valor agregado - a imagem do país lá fora continua sendo agrária-exportadora e não de exportador industrial ou de serviços - , o consumo de cafés especiais cresce no mercado interno. ${ }^{61}$ Como índice, sabemos que o crescimento do consumo das categorias especial e gourmet hoje é quatro vezes maior que o crescimento dos cafés tradicionais.

O mercado gourmet surge como esse aglomerado complexo de inovações, de um lado, a questão da qualidade dos grãos, o rastreamento da origem e a repercussão das técnicas de cultivo e preparo no sabor final do produto; de outro lado, a preocupação com questões sociais ligadas ao meio ambiente e à saúde de todos os envolvidos, por exemplo, os certificados orgânicos e aqueles que buscam proteger a biodiversidade da floresta onde o café é cultivado (shade-grown coffee, bird-friendly, etc.); além disso, as questões que envolvem as condições de trabalho, especialmente a situação dos produtores nos países menos desenvolvidos, o surgimento de certificados Fair-trade (comércio justo) no intuito de distribuir melhor o lucro pela cadeia de valor do café. ${ }^{62}$ Todos esses pontos estão concentrados e fazem parte constitutiva da experiência de consumo gourmet. Hoje, ser gourmet é também fazer parte de um estilo de vida que envolve todo o espectro socialambiental-sensorial e que muitas vezes é acionado de forma reflexiva e intencional pelos consumidores. Em certo sentido, é inegável que faz parte de um projeto político de

59 Estima-se que, para os cafés de supermercado, o lucro das empresas torrefadoras seja equivalente a cerca de 1/4 do preço no varejo, segundo o economista John Talbot (Apud LUTTINGER \& DICUM, 2006, pg. 118). Portanto, grande parte da cadeia de valor do café se realiza fora do Brasil, no caminho que começa nos importadores do grão verde, passando pelos torrefadores (roasters), para chegar no comércio à varejo.

60 SNA News. "Rui Bragueta Filho: É preciso exportar café com valor agregado". 02 jul. 2012.

61 Tal contexto poderá constituir uma experimentação para o País no que diz respeito a sua imagem de si no setor de serviços e na industrialização de produtos que, historicamente, são exportados apenas na forma de matéria-prima.

62 Tanto o processo de politização da comida quanto a segmentação gourmet do mercado se dirigem para a noção de autenticidade no trato dos alimentos, como aquilo que se contraporia à commodificação industrial. A esse respeito, Richard Wilk diz o seguinte: "One paradox of the marketplace... is that the very acts that decommodify - identifying a food as a part of an inalienable heritage... give them higher value as commodities." (Apud, HEATH \& MENELEY) 
consumo sustentável; qualidade e responsabilidade sendo os dois pilares. No entanto, interessa-nos descortinar o resultado desse processo sobre o modo de experiência e de percepção dos consumidores, a despeito dos acionamentos discursivos e das narrativas justificadoras. Nessa outra perspectiva, a gourmetização é basicamente um processo de alargamento dos estímulos oferecidos pelo mercado e também da capacidade sensória do corpo absorver esses estímulos. Trata-se da questão da diversidade dos sabores, da experimentação, ou da degustação como um novo modo de apreensão dos objetos. ${ }^{63} \mathrm{O}$ consumo de café aparece aqui mais como parte da experiência gastronômica mais ampla, potencializado pela disseminação das instâncias de realização do prazer gastronômico, do que ligado ao projeto reflexivo do eu em busca da politização do mundo cotidiano. A questão deixa de ser descobrir que formas de utopia estão sendo alimentadas pelos consumidores; a questão passa a ser ligada aos modos de percepção que estão se tornando hábitos globais, tendo em vista os atuais atravessamentos da circulação internacional de comida e de formatos de negócio rentáveis do ponto de vista econômico. O Brasil procura se posicionar nesse cenário.

63 Tim Wendleboe, um famoso barista norueguês que foi campeão em 2004 do World Barista Championship, comenta a questão das certificações da seguinte maneira: "The speciality coffee business is getting more and more in to various certifications. For example you can buy bird friendly, fair trade and organic certified coffees, yet there are no guarantees for this certified coffee to be a good tasting one. In other words, certification is not the answer to everything, and it is definitely not synonymous with quality." (WENDELBOE, 2006). 


\title{
CAPÍTULO II
}

\section{O BARISTA COMO AGENTE DO PROCESSO DE GOURMETIZAÇÃO}

\author{
"Um barista não é apenas um cara elegante que aperta \\ um botão e depois serve um café ao seu cliente. Um \\ barista é alguém que conhece a cadeia do \\ café." (SANAPO, 2013)
}

Na recente história do mercado de café, a mudança na produção e no consumo da bebida é acompanhada também do surgimento de novas instâncias de conhecimento, sustentadas por grupos de especialistas - os baristas, que são profissionais habilitados a preparar o café. Embora o conhecimento aprofundando da bebida seja uma questão de especialistas, tal como os chefs para a culinária e os sommeliers para o vinho, os estabelecimentos que oferecem cafés de qualidade acabam servindo, cada vez mais, como locais em que consumidores regulares aprendem a consumir mediante a contraposição das variedades consumidas. Em termos sociológicos, poderíamos argumentar que se trata de um contexto em que as práticas cotidianas, em sua realidade crônica, funcionam como instâncias de atualização e deslocamento de saberes, de modo que podem construir tendências ao atingir as percepções práticas dos consumidores. É comum que nesses estabelecimentos voltados para segmentos abastados sejam oferecidas várias formas de preparo do café: tipo italiano (mocca), espresso curto, longo, prensa francesa, aeropress, coado, e assim por diante. ${ }^{64}$ A justaposição de variedades internas a um mesmo produto faz com que o consumidor médio se defronte com um imperativo de escolha, o que pode implicar na recomposição de sua percepção e de seu padrão de gosto - isto é, seus esquemas perceptivos e apreciativos. Em alguns lugares, se o consumidor pedir um "cafezinho normal" é possível que ele seja confrontado pelo barista e obrigado a escolher um dentre os vários tipos da bebida, já que o "café normal” é algo que se encontra em declínio no segmento de mercado gourmet.

64 Essa diversidade também aparece na imprensa. Em 2014, a Folha de São Paulo publicou uma matéria explicando as diferentes formas de preparo do café: "Conheça o passo a passo de diferentes métodos caseiros de fazer café" (MIRAGAIA \& FREIRE, 2014), abordando os métodos French Press, Chemex, Hario, Mocha, Aeropress e Clever. Em 2015, o Estadão também publicou uma matéria explicativa: "Como fazer um bom café em casa" (PERALVA, 2015) — abordando os métodos coador de pano, Moka, Hario, Aeropress, prensa francesa e drinks feitos com café. 
Apesar de deter a posição de maior exportador de café no mundo há mais de 150 anos, é apenas muito recente na história do café brasileiro que surgem instituições voltadas para a disseminacão de uma apreciação mais cuidadosa e complexa do produto, isso do lado do consumo. Porque até os anos 2000, as organizações do mundo do café focavam apenas na posição dos plantadores, dos fornecedores, dos atacadistas e dos vendedores a varejo. Não havia nenhuma instituição focada na troca de informações entre baristas e na promoção das habilidades próprias ao ofício. As instituições que existiam até então eram mais focadas no lado da produção/indústria, como a ABIC e a BSCA. ${ }^{65}$ Em 2003, nasceu a guilda de baristas dos Estados Unidos (Barista Guild of America). Dois anos depois, em 2005, nasceu a similar Associação Brasileira de Café e Barista (ACBB). Além de associações do tipo, uma série de eventos passaram a cumprir um papel formador em matéria de gosto e de apreciação técnica da bebida. Nos países nórdicos, por exemplo, o evento Nordic Barista Cup funciona, desde 2003, como um contexto de agregação entre os baristas daqueles países, promovendo competições e workshops com a intenção de compartilhar conhecimento, conforme demonstra o slogan do evento: "Esteja junto, aja junto, aprenda junto", ${ }^{66}$

Nossa investigação neste capítulo terá por objeto a montagem institucional da expertise de café no Brasil a partir do estudo da figura do barista, que a nosso ver desempenha um papel fundamental como ponte - ponto de inflexão e de mediação - entre a produção e o consumo final do produto. No contexto de uma progressiva especialização dos saberes ligados à comercialização do café, o barista aparece como aquele agente da cadeia de valor dotado de um saber-fazer prático: uma competência de preparo da bebida cujo empenho cuidadoso pode resultar na disseminação de uma disposição estéticagustativa para maiores contingentes de consumidores, conceito que será desenvolvido mais

\footnotetext{
65 Lembrando que a Associação Brasileira da Indústria de Café (ABIC) é de 1973 e a Associação Brasileira de Cafés Especiais (BSCA), de 1991.

66 "Be together, act together, learn together".
} 
adiante. ${ }^{67}$ Quando atentamos para a história da gastronomia, percebemos que o convívio é uma poderosa ferramenta de criação de hábitos de consumo. No caso do café, a história não é diferente. Nossa hipótese é de que a disseminação geral do conhecimento técnico do café é resultado, talvez em sua maior parte, do contato rotineiro do consumidor com o ofício do barista. O ofício do barista é marcado por uma série de rituais que são aprendidos nos cursos de formação de barista ou no próprio dia-a-dia da cafeteria. Nós interpelamos os baristas de alguns estabelecimentos da cidade de Brasília e São Paulo a fim de apreender, primeiramente, os caminhos que o levaram à expertise e, em segundo lugar, os resultados do contato dessa expertise com o mundo consumidor. ${ }^{68}$

O termo barista é de origem italiana e, na Itália, significa qualquer pessoa que trabalha em um bar servindo bebidas quentes ou geladas, com ou sem álcool. Nas outras línguas, a expressão passou a ser usada para designar o profissional que trabalha servindo e preparando café no balcão das cafeterias. Há quem diga que Robert Schulz, o $C E O$ da Starbucks, disseminou o termo para o resto do mundo, após uma viagem para Itália nos anos 1980. O termo veio inicialmente associado ao manejo da máquina de espresso, até hoje considerado um dos métodos mais complexos de preparo da bebida. Uma reportagem de 2004 da Revista Super Interessante, intitulada “O que é barista?”, estabelece a conexão entre a consolidação da profissão barista e o surgimento de cafeterias especializadas em espresso aqui no Brasil:

67 Para adiantar um pouco, trata-se da habilidade que o consumidor pode desenvolver de analisar sensorialmente um produto alimentar a fim de compará-lo sucessivamente com outros produtos congêneres. Por consequência, engendra-se um processo de auto-conhecimento via consumo das próprias preferências de escolha no mercado, agora tendo por base a correlação entre as qualidades organolépticas do produto (aquelas percebidas pelos sentidos) e suas características gerais, marca, região de origem, processo de fabricação, embalagem, percepção semiótica final, etc. Isso nos remete à discussão sobre a contribuição que um artefato material pode dar à cognição do consumidor, mais especificamente, à formação das suas preferências (COCHOY, 2004). Todavia, no nosso caso de estudo, os objetos materiais não "informam" o consumidor sozinhos, eles são acompanhados da figura dos especialistas que estão ali, logo ao lado, para ajudar e informar o processo de escolha.

68 As cafeterias investigadas foram as seguintes. Em São Paulo, seis: Octávio Café, Il Barista, Por um Punhado de Dólares, Beluga Café, Urbe Café, Suplicy e Santo Grão. Em Brasília, dez: Bellini Coffee Experience, Café Cristina (202 sul e Iguatemi), Ernesto, Los Baristas, Grenat (315 norte e Iguatemi), Suplicy, Clandestino, Objeto Encontrado. As cafeterias foram selecionadas tendo em vista a proposta de valor que elas trazem, cujo diferencial reside no fornecimento de cafés especiais diferentes daqueles encontrados em supermercados comuns. Além disso, é importante ressaltar que todas essas cafeterias valorizam a questão da "rastreabilidade da fazenda ao pacote", característica fundamental daquilo que alguns autores chamam de "terceira onda do café". Obviamente, tal proposta de valor se correlaciona diretamente com o alto poder aquisitivo das regiões onde essas cafeterias estão localizadas, conformando uma condição econômica que abre caminho para a capacidade de experimentação estilizada do mercado. 
Figuras cada vez mais freqüentes em bares, cafés e restaurantes, os baristas começaram a se espalhar pelo país durante o boom do expresso, há alguns anos. O famoso "cafezinho" sempre fez parte do dia-a-dia do brasileiro, seja servido com um bolo à tarde ou tomado às pressas de manhã na forma de um pingado na padaria da esquina. Mas foi o expresso que tornou o consumidor nacional mais exigente - para prepará-lo, a matéria-prima precisa ter mais qualidade. Além disso, foi ele que abriu caminho para os cafés, verdadeiros bares especializados na bebida, que viraram manias nacionais. (Redação Super Interessante, 2004) ${ }^{69}$

O sujeito que maneja uma tal máquina deve seguir uma série de parâmetros para assegurar a qualidade da bebida. Por exemplo, assegurar que o grão seja moído na hora ou no máximo 30 minutos antes do preparo para não oxidar; que a máquina seja limpa após o uso diário; que a compactação do pó seja firme, constante e nivelada; que o tempo de extração tenha uma certa constância para os $25-35$ ml, entre 20 e 30 segundos; que a crema esteja na cor e consistência certa ("cor de calda de pudim", "cor de avelã"), indicando que o espresso não está sub-extraído ou super extraído; que a bomba de água da máquina esteja em torno de 9 bars de pressão; e assim por diante..$^{70}$ No entanto, por mais que o barista siga os parâmetros listados, pode ser que o café não saia bom. Mais importante de tudo, é preciso prática, como demonstra o seguinte testemunho:

Mesmo quando éramos capazes de lembrar corretamente cada passo do preparo, nosso espresso permanecia inconsistente. Por que? A resposta reside no coração da aquisição de qualquer habilidade (e fazer bebidas de espresso é certamente uma habilidade). A resposta é a prática, não o seguimento de uma lista de passos para fazer um bom café, nem a mais surpreendente descrição dada pelo seu treinador que você escuta sentado em uma cadeira. O que é necessário, em primeiro lugar, é a prática do toque despendido, por sobre o balcão, para nivelar o café moído. Sem uma correta distribuição do café, a água quente faz um buraco central nos grãos. Em segundo lugar, tem também a prática de quão duro pressionar os grãos. Se apertar demais, a água vai fluir muito lentamente, extraindo apenas uma fração dos óleos saborosos; se apertar pouco, a água corre e mal consegue extrair os sabores.

69 Redação Super Interessante. “O que é barista?”. Revista Super Interessante, Edição 196, jan. 2004.

70 No mundo do espresso, há inclusive uma espécie de mantra entre os baristas: "no crema, no serva" (LAURIER, 2003). 
(LAURIER, 2003, pg. 7-8) $)^{71}$

Ocorre que, atualmente, a disseminação de máquinas caseiras de espresso surge como um substituto que automatiza o trabalho cuidadoso do barista. A Nespresso, marca pertencente ao grupo suíço Nestlé, é hoje a maior fabricante desse tipo de máquina que funciona à base de cápsulas. Os grãos encapsulados da empresa, que chegaram ao Brasil em 2006, são vendidos pela internet (Nespresso club), pelo telefone e também em 14 boutiques nacionais da marca. Ao priorizar o contato direto com o consumidor, as boutiques materializam os conceitos de customização e exclusividade atrelados à marca; esses estabelecimentos já somam mais de 400 no mundo. ${ }^{72}$ No discurso da empresa, o diferencial do produto, além da qualidade do café, é a alta tecnologia incorporada nas máquinas: elas são dotadas de controle eletrônico de temperatura da água e de bombas de alta-pressão (19 bars de pressão contra 9 bars das máquinas de espresso tradicionais). Já as embalagens metalizadas a vácuo são utilizadas para reter o sabor e o frescor do café. A empresa, que já havia desenvolvido o protótipo da máquina na década de 1970, só começou a comercializar as máquinas na década seguinte, em 1986. Porém, o verdadeiro crescimento das vendas ocorreu nos anos 2000, mantendo uma média de 30\% ao ano (MATZLER, 2013). Munida de um montante de 1700 patentes, a empresa não conseguiu conter os concorrentes que, desde 2010, passaram a vender versões genéricas das cápsulas suíças. O imbróglio jurídico se deu quando várias concorrentes processaram a Nespresso, dentre elas a D.E Master Blenders 1753 (antiga Sara Lee) e a Ethical Coffees (fundada

71 "Even once we were able to correctly remember each step of filling the handle with coffee, our espresso remained inconsistent. Why? It is a simple answer at the heart of acquiring any skill (and making espresso-based coffees is certainly a skill). The answer is practice, not the rote following of a list of steps to making an espresso, nor the most amazingly detailed description given by your trainer as a piece of talk whilst you sit in a chair and listen. What is needed is firstly practice in the sharp tap on the shelftop that rapidly evens out the dispensed coffee in the handle. Without an even spread of coffee, hot water makes a central channel for itself through the grains taking only a fraction of the flavoursome oils. And secondly practice in how hard to press when tamping the grounds down. Tamp too hard and the water flows too slowly through the granules taking too much out of them; too soft and the water rushes through barely extracting any flavours."

72 Vender cápsulas em lojas próprias e não em supermercados apresenta outra vantagem segundo Jean-Marc Duvoisin, chefe executivo da marca: "Para Duvoisin, vender em loja própria dá a eles uma dimensão mais correta do gosto do cliente, o que é um diferencial competitivo." (Redação Folha de São Paulo. "Com perda de patentes, Nespresso perde espaço para concorrentes". Folha de São Paulo, Mercado, 01 jan. 2014). 
pelo antigo $C E O$ da Nespresso). ${ }^{73} \mathrm{~A}$ queda das patentes significa que as cápsulas comercializadas por outras marcas podem ser utilizadas nas máquinas da Nespresso. Dessa forma, o mercado das monodoses de café se diversifica e ganha novos atores. ${ }^{74}$ Ainda assim, a Nespresso permanece como a líder, sendo responsável por 98,2\% do mercado brasileiro e, a nível mundial, estima-se que represente $65 \% .{ }^{75}$ É interessante assinalar que o Brasil é o maior fornecedor de matéria-prima da empresa, mais de $60 \%$ dos grãos presentes nas cápsulas são brasileiros. Tendo em vista que o Brasil é o segundo maior país consumidor de café do mundo, constata-se que a presença das cápsulas aqui ainda é tímida, em parte porque o coado detém a preferência nacional. As cápsulas ou monodoses de café respondem por cerca de 2\% das vendas totais de café no país; nos Estados Unidos a fatia é de 17\% e em alguns países da Europa chega a 30\% (Redação EmabalagemMarca, 2013). A França e a Suiça são os países de maior penetração comercial das cápsulas. Alguns comentadores do mundo do café, como Jim Hoffman, asseguram que "as cápsulas vão vencer" (sic) e que o serviço de espresso baseado em baristas altamente treinados está ameaçado a perder espaço. ${ }^{76}$ Para se ter uma ideia, em 2009, a marca representou cerca de $4 \%$ do faturamento do conglomerado Nestlé. ${ }^{77}$ Não obstante, alguns comentadores apontam para outra direção, na medida em que separam o mercado das máquinas automáticas de espresso daquele das cafeterias assentadas na figura do barista - o seguinte argumento poderia se estender também em relação às máquinas domésticas:

Para cada loja que abre com sua máquina de café expresso semi-automática, existe uma da terceira onda, trabalhando horas extras, manchando as mãos de marrom de café enquanto prepara com artesania a xícara perfeita. A terceira onda é uma reação àqueles que querem automatizar e homogeneizar os cafés especiais. (SKEIE, Trish R. "Norway and Coffee". The

73 O conglomerado D.E Master Blenders é dono de marcas como Café do Ponto, Caboclo e Pilão. Em 2015, a holandesa D.E Master Blenders e a rival norte-americana Mondelez International uniram suas unidades de café em um negócio (joint venture) com o objetivo de enfrentar a líder de mercado Nestlé.

74 Em 2012, a Starbucks entrou no segmento com as K-Cups, operando principalmente nos Estados Unidos, mas também presente em outros países. Outras concorrentes internacionais são a Lavazza, a Krups e a Senseo. No mercado brasileiro, assistimos a uma proliferação de marcas, algumas vindas de fora, outras já conhecidas no comércio à varejo: Delta Q, L'Or (do Café do Ponto, que é da DE Master Blenders), Seleto (do grupo Mex), Grupo 3corações, Lucca Cafés Especiais, etc. Redação EmbalagemMarca. "O gigante vai acordar?”. Revista EmbalagemMarca, Ano XIV, № 169, Setembro, 2013.

75 MADUREIRA, Daniele. "Cresce disputa pelo espresso caseiro". Valor Econômico, Empresas, 30 out. 2012.

76 Conferência “L'espresso italiano" [youtube], James Hoffman. World of Coffee, 2014.

77 PACHECO, Paula. “Todos querem ser um Nespresso". Estadão, E\&N, 19 jul. 2010. 
Flamekeeper, Spring 2003) 78

Essa mesma perspectiva se repete na fala do barista Tim Wendelboe, por exemplo:

"Nós não seríamos o que somos se não fosse pelas automáticas", diz Tim Wendelboe, barista norueguês campeão por dois anos consecutivos. "Nós sabemos que gosto tem o café (automático), e nós queremos nos distanciar dele." (SKEIE, Trish R. "Norway and Coffee". The Flamekeeper, Spring $2003)^{79}$

No curso de barista que realizei no Coffee Lab, o instrutor Renato Gutierres elogiou as inovações trazidas pela Nespresso. Disse que a ideia era "genial", pois cafés do mundo todo eram colocados diante do consumidor para serem tomados à distância de um clique. É possível dizer que também o design multi-colorido das cápsulas, ao simplificar o processo de escolha do consumidor, é uma excelente maneira de contornar uma diversidade que muitas vezes é tida como ofuscante. A única ressalva que Renato levantou foi em relação ao preço - fazendo os cálculos, 250 gramas de café Nespresso sai em torno de 80 reais, quase o dobro do preço de micro-lotes artesanais, isso para um produto de escala industrial. ${ }^{80}$ No momento, as monodoses de café da Nespresso somam 24 variedades, chamadas pela própria marca de grand crus (denominação transposta do mercado de vinhos que designa as melhores regiões produtoras), incluindo aqui as edições limitadas e sazonais, que existem para renovar esporadicamente o interesse do consumidor. É certo

78 "For every outlet that opens with a semi-automatic espresso system, there is a Third Waver, working overtime, staining her hands brown with coffee as she handcrafts the perfect shot. The Third Wave is a reaction to those who want to automate and homogenize Specialty Coffee."

79 “' 'We wouldn't be what we are if it weren't for the automatics,' says Tim Wendelboe, Norway's reigning Barista Champion for two years running. 'We know what that (automatic) coffee tastes like, and we want to get away from it.'."

80 É necessário observar que a Nestlé não ganha dinheiro com as máquinas de café, elas são produzidas por parceiros licenciados a "preços econômicos", segundo a empresa. A verdadeira fonte do lucro estaria na venda das cápsulas, com uma margem de lucro de 85\%, comparado aos 40-50\% de uma marca comum de café em pó (MATZLER, 2013). 
que tudo isso, de alguma forma, ajuda a disseminar a cultura da apreciação de café. ${ }^{81}$ Ao mesmo tempo, ganha relevância a questão do luxo e da afirmação das posições de classe via o consumo de produtos transpostos para essa lógica. Nas palavras de Elizabeth Primo: “a empresa transformou a ideia de café, elevou-o à categoria de produto de luxo acessível, isso ao torná-lo mais personalizável". ${ }^{82}$ Esse enunciado nos faz lembrar o título, intencionalmente paradoxal, de uma matéria que saiu na revista The Economist sobre o crescimento do mercado do luxo: "Exclusively for all". ${ }^{83}$ A Nespresso se insere perfeitamente no paradoxo: faz de tudo para construir uma imagem de exclusividade (à qual o próprio nome da rede de compras alude: Nespresso $C l u b$ ), ao mesmo tempo em que procura se expandir para os quatro cantos do mundo. Como resultado dessa tensão, a moderna máquina de café se banalizou enquanto item de luxo, virou uma espécie de gadget nas salas de estar e nos halls de entrada de escritórios comerciais das classes que possuem certo poder aquisitivo. Sua função como bem de distinção ou de exibição de status é por vezes maior que o seu poder de transformar os seus consumidores em conhecedores do grão, isto é: especialistas em matéria de gosto, connoisseurs, apreciadores, estetas da bebida. Exatamente por essa razão optamos por afastar da análise posterior o caso da Nespresso, assim como o caso da Starbucks, e nos concentramos nas cafeterias independentes. Isso porque, nessas grandes marcas, é possível dizer que há uma primazia da função simbólica da distinção sobre a função estético-gustativa do alimento, o que pode ser razão suficiente para contribuir para o processo de gourmetização, mas não levá-lo ao pé da letra. Aqui compartilhamos da concepção do sociólogo John Manzo (2010), quando este apresenta as seguintes ressalvas metodológicas em seu trabalho:

81 Em relação à qualidade, uma reportagem do Estadão faz ressalvas ao produto Nespresso: "Como a força da água é muito grande, mais compostos insolúveis são liberados e eles, com a água e o ar, se estruturam para formar a crema densa e alta. A pressão que ajuda a formar a crema é favorável também ao aroma, intensificando a liberação e a mistura dos compostos voláteis ao ar. A favor do cheiro, mas contra o gosto, liberando óleos que agravam amargor. Na prática, algumas características do método de extração podem se sobrepor ao café usado na cápsula, uniformizando nuances. (...) Dentro do sistema Nespresso, os possíveis problemas da extração são corrigidos nas cápsulas, com mistura de grãos da café da mesma espécie em diferentes graus de torra. A acidez, por exemplo, pode não vir de um tipo de grão, mas da torra mais clara de um tipo de café. É um gosto cientificamente calculado." (MARQUES, Daniel Telles. "Questão de pressão". Estadão, Paladar, 06 fev. 2013).

82 "the company changed the idea of coffee elevating into a luxury accessible product by personalizing the idea of coffee" (PRIMO, 2012, pg. 1).

83 Special Report: Luxury. The Economist, December 132014. 
Se essa investigação tivesse começado, como faria a sociologia analítica formal ao estudar os aspectos sociais do consumo, com a questão da relação entre o status social das pessoas e as suas preferências em matéria de café, então nós provavelmente iríamos acabar bem longe do fenômeno da terceira onda de café. Isso acontece por causa da relação entre o modelo de varejo da cadeia Starbucks e a consequência que seus clientes tendem a ser ricos (Bowman, 2008). Pelos padrões da terceira onda, a Starbucks e seus similares são fornecedores de cafés terríveis por várias razões e, ainda assim, são notáveis fabricantes de status, mesmo que os seus clientes careçam de gosto, pelo menos de gosto por café. Essas nuances são simplesmente desconhecidas pela análise estrutural e, de fato, uma tônica depositada na classe socioeconômica e no café poderia nos levar até a Starbucks, que é precisamente onde nós não queremos ir. (MANZO, 2010, pg. 153) ${ }^{84}$

Talvez pela banalização do acesso ao espresso e a consequente perda de seu valor de prestígio, ou quem sabe pela penetração da tecnologia e a consequente automatização do serviço de preparo, o café coado foi resgatado nos últimos anos e passou a ser valorizado pelos adeptos da onda artesanal de café. É o que podemos reconhecer na fala de James Hoffman, prestigiado comentador do mundo do café, quando diz que "o café coado (pour-over) é o novo produto especial" e que "o espresso deixou de ser o novo produto especial" ${ }^{85}$ É interessante notar que, no contexto dessa nova tendência, o Brasil estaria numa ótima posição, já que por aqui o coado sempre fez parte da tradição nacional. Outro país em que essa tradição é forte é o Japão. É de lá que vêm os populares coadores da marca Hario, em especial os porta filtros em formato cônico (ao invés do formato "chapéu de Napoleão" da Melitta), dotados de estrias avantajadas para uma melhor distribuição da água derramada. O famoso modelo Hario V-60, confeccionado em vidro, porcelana ou plástico, é hoje bastante popular no segmento das cafeterias especializadas. O produto, que surgiu em 2005, custa por volta de 35 reais na sua versão plástico; já foram vendidos mais de 1 milhão produtos V60 no mundo. ${ }^{86}$ Outro produto bastante conhecido da marca Hario é o sifão (syphon), produzido desde 1948, uma engenhoca que parece aqueles tubos de

84 "if this investigation had started, as formal analytic Sociology would when studying the social aspects of coffee consumption, with the question of the relationship between persons' social statuses and their coffee-related preferences, then we would likely end up very far from the third wave phenomenon. This is because of the relationship between the retail model of the Starbucks chain and the consequence that its customers tend to be wealthy (Bowman, 2008). Starbucks and its ilk are, by third wave standards, appalling coffee purveyors for many reasons and yet are still status makers, even though their customers might lack taste, at least, taste in coffee. These nuances are simply unavailable to structural analysis and indeed a primary focus on socioeconomic class and coffee might lead us to Starbucks, which is precisely where we don't want to go."

85 Conferência "L'espresso italiano" [youtube]. James Hoffman. World of Coffee, 2014.

86 "Hario rides the third wave". BeanScene Magazine, June, 2013. 
ensaio usado em laboratórios de química. ${ }^{87}$ Quanto ao componente sensorial, é sabido que o preparo de café no sistema Hario dá destaque para a acidez da bebida, o que o diferencia da tradição brasileira que, em geral, privilegia o amargor. É importante ressaltar aqui que a vinculação entre o amargor e o café possui raízes antigas. Sabe-se que, até o início do século 20 , o café era feito despejando-se água quente sobre o pó em recipientes furados de metal ou cerâmica. Essa forma de preparação deixava resíduos e, consequentemente, sabor amargo na bebida. A invenção dos coadores de pano surgiu como uma "solução" para esses problemas, já que, ao reter parte do óleo dos grãos no pano, o método diminuiu a concentração dos compostos clorogênicos na bebida final. ${ }^{88}$ Ainda assim, a preferência em alguns lugares continuou sendo pelo sabor concentrado e amargo da bebida. A história do café coado no Brasil remonta às primeiras tradições de preparo da bebida, que vieram da Europa através dos imigrantes:

A história é a mãe do gosto. A popularização do café se deu pelo coador. Era assim que os europeus preparavam a bebida nas cafeterias das grandes cidades. Coador de pano na mão e pó na água quente na outra, explicou a historiadora Ana Luiza Martins, autora do livro A História do Café. (...) E quando a bebida chegou ao Brasil, lá em 1727, na rabeira da crise do açúcar, era coada que se bebia. E foi assim até a segunda metade do século 20, mesma nas fazendas de café cheias de imigrantes italianas. (...) A urbanização tardia do Brasil ajudou a perpetuar o hábito do cafezinho. As máquinas de expresso deram as caras no Brasil a partir dos anos $1950 \mathrm{em}$ cafés luxuosos das cidades e dominaram o consumo nos centros urbanos do homem moderno regido pelo trabalho na indústria e pelo tempo marcado pelo relógio. Por muito tempo, coado e expresso conviveram nas cafeterias, mas a partir dos anos 1980, a moda do expresso pegou e o coado perdeu espaço nos restaurantes. ${ }^{89}$

87 Sobre a história da empresa japonesa, Ensei Neto faz uma breve descrição: “A Hario Glass Co. Ltd. é uma tradicional indústria japonesa de vidros especiais para laboratórios e medicina, fundada em 1921 por Hiromu Shibata. No início dos anos 60 sua atual fábrica, localizada em Koga, Ibaraki, entrou em operação. Com reputação feita no meio médico e científico, passou a desenvolver diversas linhas de produtos, atendendo desde o setor de automóveis até a chamada linha residencial (tableware). E neste segmento se destacou graças ao belo design de suas peças somado às geniais soluções para serviços de Chá e Café. (...) Até o final dos anos 90 as peças para estes serviços eram conhecidos apenas pelo sofisticado consumidor japonês. Na virada do milênio, a empresa resolveu fazer sua estréia no mercado norteamericano. Bingo! (...) Rapidamente ganhou a atenção e o respeito dos descolados apaixonados pelo café da Costa Oeste. Design caprichado e grande conhecimento demonstrado na concepção de cada peça, sua estréia teve efeito fulminante entre os baristas das cafeterias mais vanguardistas de Seattle, WA, e Portland, OR. Hoje sua linha tem peças que são objeto de desejo de todos os apaixonados por café!". NETO, Ensei. "Como Preparar A Mais Fantástica Xícara de Café - 1". Blog The Coffee Traveler, 11 abr. 2012.

88 Os filtros de papel surgiram no começo do século XX. Em 20 de junho de 1908, a empresa alemã Melitta apresentou o pedido de patente do filtro em Berlim (Folha de São Paulo, 2014).

89 Redação Estadão. "E no princípio era apenas o pano". Estadão, Paladar, 17 out. 2012. 
Se nos anos 1980 e 1990 a moda era o café espresso, nos últimos anos o interesse pelo coado foi resgatado. Em Novembro de 2012, uma reportagem do caderno Paladar do Estadão, "Aqui tem café no bule", apresenta os vários tipos de preparo de café coado que existem no Brasil. É interessante que, na reportagem, o coado e o espresso não aparecem em disputa, pois é destacada a similaridade de sabor entre os dois modos de preparo. Ainda assim, elenca-se o coado como o melhor método para perceber as qualidades sensoriais da bebida:

Café coado é ao gosto do freguês. Os coadores dão à bebida características próprias e estão voltando à moda entre os gourmets. Aos poucos, pelo mundo, esse café que toma uns minutos para ser passado, é menos encorpado e não tem espuma, começa a recuperar o espaço perdido para o expresso nos últimos anos. (...) Em geral, os brasileiros gostam do travalíngua forte do cafezinho - feito com o pó na água, cheio de compostos clorogênicos (tipo o gosto de jilós) e de cafeína, bem adoçado. (...) A preferência nacional pelos sabores fortes costuma ser apontada entre os motivos para o crescimento do expresso. Mas isso está em mudança desde que bons cafés deixaram de ser apenas produzidos para exportação, os brasileiros passaram a apreciar melhor o café e, paradoxalmente, os métodos que concentram sabores (como o expresso) não são os melhores para perceber as qualidades da bebida. É como se as partículas brigassem para chegar ao nariz e à língua. No café coado, não há tanto congestionamento e as partículas ficam mais ágeis para o seu prazer..$^{90}$

No contexto internacional, sabe-se que a preferência por coado ganhou impulso na virada dos anos 2000, quando os produtos da marca Hario entraram no mercado americano e penetraram as prateleiras das cafeterias mais "vanguardistas". Depois que chegaram nas cidades de Seattle (WA) e Portland (OR), cidades que têm forte tradição de torrefação de café, os métodos de preparo da Hario foram sendo incorporados nos eventos de barista e nos campeonatos internacionais. ${ }^{91}$ Em poucos anos, os porta-filtros modelo V60 se propagaram rapidamente pelo mundo, contagiando os novos adeptos com a nova certeza da qualidade técnica. Nesse meio tempo, também outros métodos passaram a ser valorizados, todos de menor concentração de sabor em comparação ao espresso. Em geral, defende-se que esses métodos não congestionam as características sensoriais da bebida. Por mais que a Nespresso tente criar uma atmosfera gustativa na apresentação dos seus produtos, os outros

90 MARQUES, Daniel Telles. "Aqui tem café no bule”. Estadão, Paladar, 17 out. 2012.

91 Desde 2011, a empresa é uma das patrocinadoras do World Barista Championship (WBC). Além disso, existe o World Brewers Cup, que é um campeonato só voltado para o preparo de café filtrado e que utiliza oficialmente os produtos da Hario. 
métodos de preparo, em especial o coado, aparecem como mais cuidadosos à luz da busca contemporânea por autenticidade. ${ }^{92}$ Ainda por cima, eles levam bastante tempo para serem preparados, o que agrega valor ao serviço - por volta de 5 minutos, em comparação com os segundos da máquina automática. Aos poucos, alimenta-se uma cultura de degustação que anda em conjunto com a valorização da profissão barista que prepara a bebida.

Figura 8 - Os equipamentos da Hario
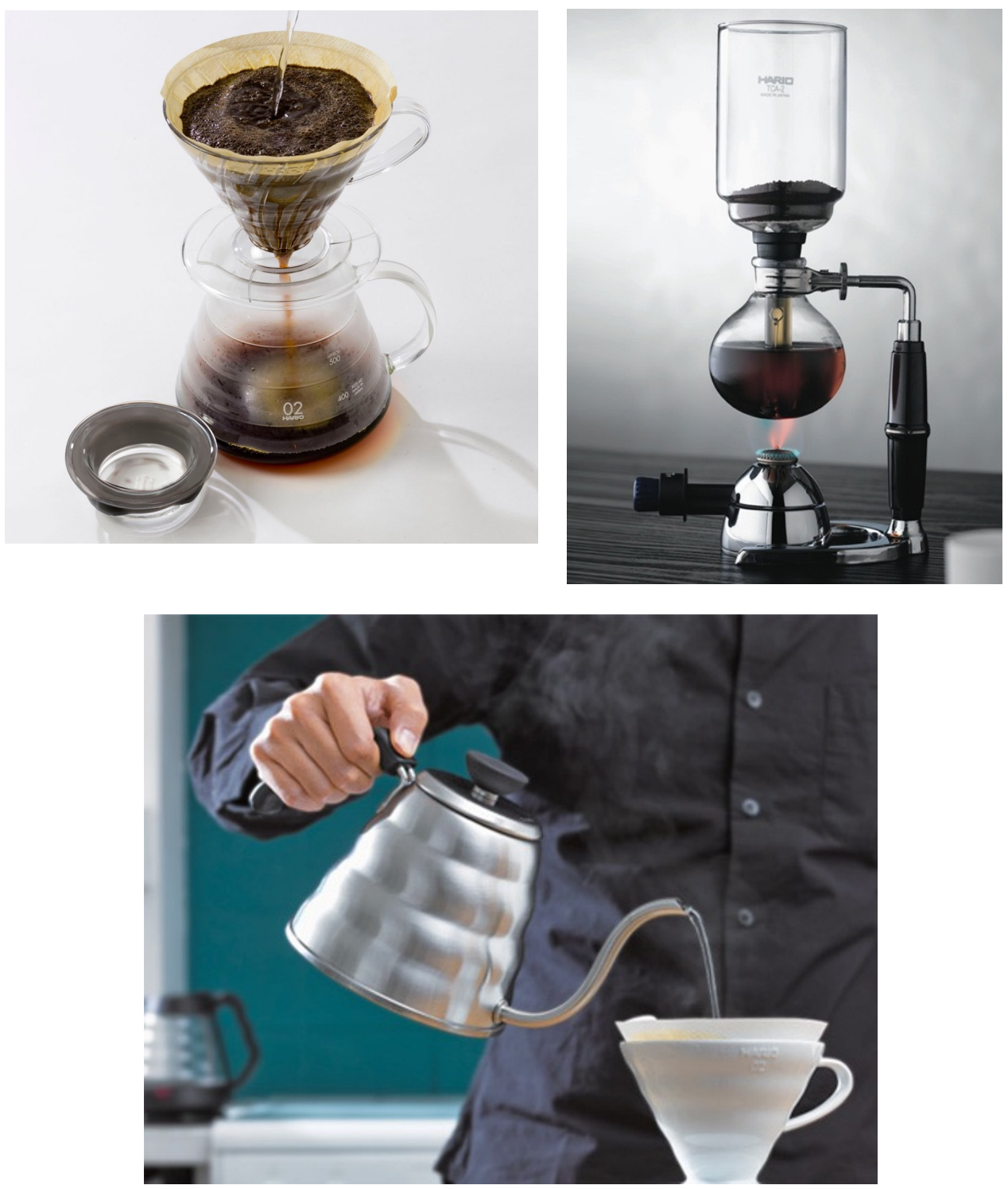

Fonte: montagem elaborada pelo autor a partir do Google Imagens

92 Nesse ponto, podemos dizer que a variedade de cores das cápsulas Nespresso representa a variedade de sabores oferecidos ao consumidor, e isso faz parte do marketing da empresa. 
Com a progressiva segmentação do mercado de cafés, o termo barista passou a ser associado não apenas para denotar a profissão de servir as bebidas de café, mas também a posse de um conhecimento técnico e refinado da bebida. Afinal, o próprio barista precisaria experimentar aquilo que ele prepara para saber se está no ponto certo de servir. No curso de barista que realizei no Coffee Lab, o instrutor Renato Gutierres chamou atenção para o fato de que em estabelecimentos que dão pouca importância para a qualidade do café, como os "cafés de aeroporto", geralmente o dono não gosta que o barista prove o café. Às vezes, há inclusive uma cota determinando o limite de consumo dos próprios funcionários. Todavia, seguindo as tendências da gastronomia de luxo, Renato defendeu que é fundamental que os funcionários provem aquilo que estão servindo. Nas cafeterias gourmets, isso se torna cada vez mais presente. Dessa forma, o ofício de barista envolve não apenas as habilidades de preparo da bebida, mas o plano da degustação, que é um modo socialmente construído de apreensão dos objetos. Isso implica numa valorização crescente dos componentes intrínsecos da bebida, sua sensorialidade, o que se sobrepõe ao plano simbólico da sociabilidade do ato de tomar café nesses espaços públicos. O barista também precisa entender dos tipos, sabores e aromas do café. Além do que, com a multiplicação das formas de preparo, o ofício do barista fica cada vez mais performático e permeado por nuances gestuais que multiplicam as diferenças sensoriais da bebida oferecida. Nesse sentido, o barista hoje é requerido como um profissional altamente habilidoso, que precisa ser capaz de identificar os mais diversos matizes e variações na degustação da bebida final e, acima de tudo, saber performatizar esse conhecimento diante do consumidor. Não obstante, essa é uma tendência muito recente. Segundo estimativas, existem cerca de 2 mil baristas no Brasil, se aplicarmos o termo àqueles que não possuem certificado mas que trabalham em cafeterias servindo café. ${ }^{93}$ A profissão, que existe há mais de meio século na Europa, recentemente começou a crescer no Brasil em virtude do boom das novas cafeterias e do lançamento de cafés especiais no varejo. Para se tornar um barista profissional é preciso passar por cursos de formação e hoje no Brasil esses cursos são livres e possuem duração variada. A formação agrega valor no contracheque do trabalhador. Segundo um reportagem de 2012, um barista, em São Paulo, começa a carreira

93 BARBOSA, Miguel. “A APEX e a promoção do café brasileiro”. Revista do Café, 2012. 
com um salário médio de R\$ 1,3 mil. Com uma certificação, ganha $30 \%$ a mais e não há limite para os cursos e os aumentos. ${ }^{94}$ Segundo a imprensa, as perspectivas para o crescimento da profissão são grandes, já que o mercado de café passa por um processo de segmentação em direção ao consumo de luxo. ${ }^{95}$

Entre os dias 29 de Janeiro e 10 de Fevereiro (2015), fui para São Paulo com o intuito de realizar um curso de Barista no Coffee Lab, um laboratório de café criado por Isabela Raposeiras. Além disso, a intenção era aplicar questionários nas cafeterias da cidade. Dois questionários foram feitos, cada qual com dez perguntas, sendo um para os baristas e outro para os consumidores. No primeiro dia de aplicação dos questionários, um dos consumidores abordados disse que era "um bebedor muito primitivo de café", enquanto outro aceitou responder o questionário mas com a ressalva que não entendia nada daquilo. Isso aconteceu no Octavio Café, localizado numa região repleta de escritórios no Jardim Paulistano, e foi suficiente para eu entender que o mundo do café naquele contexto representava um tipo de expertise que constrangia as pessoas que se consideravam leigas no assunto. Nesse mesmo contexto, os baristas, que haviam sido treinados na própria rede Octavio, não mediam palavras para fazer julgamentos mais gerais sobre o universo do café, tais como quando um deles disse que "o brasileiro só toma café ruim, torrado, carbonizado". A confiança podia ser percebida nos funcionários do estabelecimento. O contraste entre o consumidor passageiro e o especialista treinado tornou-se patente, então, no primeiro dia de aplicação dos questionários, o que me fez repensar a forma de abordagem dos consumidores no intuito de diminuir ao máximo o possível desconforto gerado caso eles me tomassem como um especialista "normativo" do mundo do café, ao mesmo tempo em que pudéssemos captar essa normatividade em ação. Depois do Octavio Café, me dirigi para a filial do Il Barista que se encontra dentro da Casa do Saber, também no Jardim Paulistano. Ali a situação se inverteu, percebi muito mais insegurança por parte dos respondentes baristas. A mulher que estava manejando a máquina de espresso disse que

94 Faltam profissionais baristas no mercado. Jornal da Globo. Rio de Janeiro: Rede Gobo, 16 out. 2012. Programa de TV.

95 A fala do consultor de panificação Aires Natario é expressiva dessa tendência: "Como o Brasil é referência no mundo como produtor de café, eu acho que a gente tem que ter o melhor café do mundo também. O café tem que ser servido como uma bebida fina, assim como é o vinho, assim como é uma boa champanhe" (Faltam profissionais baristas no mercado. Jornal da Globo. Rio de Janeiro: Rede Gobo, 16 out. 2012. Programa de TV). 
havia feito um curso de barista, mas que não o considerava muito porque não tinha sido muito bom. Em relação ao paladar do café, a mesma barista disse o seguinte: "não gosto muito do gosto, mas gosto de trabalhar com isso, de distinguir, de saber diferenciar". É possível observar que havia uma boa vontade por parte da entrevistada em relação ao desenvolvimento da sua capacidade de distinguir os componentes do café, mesmo que ela não fosse entusiasta incondicional da bebida. Trata-se de um traço marcante do setor de serviços o fato de os funcionários servidores acreditarem que precisam desenvolver continuamente sua capacidade de consumo (no caso, o paladar) para melhor servir aos consumidores. Diferente do produtor de matéria-prima que se encontra distante na cadeia produtiva e que mal conhece o resultado final do produto, o funcionário do setor de serviços, em tese, precisa entender bastante do produto final. ${ }^{96}$ Ele precisa consumir para melhor servir e servir bem para que os fregueses voltem a consumir, o que parece ser um dos princípios essenciais desse tipo de negócio.

À medida que fui entrando no universo dos baristas, descobri que existe uma tendência de estabelecer lugares-comuns em matéria de gosto. A maioria dos baristas entrevistados fazia alguma referência ao fato de que o café escuro que o brasileiro está acostumado é, sensorialmente falando, torrado demais, queimado, carbonizado, o que implicaria em perda das características complexas de sabor. Para quem não passou por um processo de treinamento técnico, esse julgamento soa um tanto arbitrário, já que informado por outros parâmetros de educação sensorial, afinal, são outras histórias de formação do corpo. Em termos de julgamento estético, é comum se apelar à ideia do belo como algo desvinculado do processo de constituição do repertório acumulado de experiências, sendo o gosto pela beleza muitas vezes tomado como imutável, natural e atemporal. O sociólogo francês Pierre Bourdieu (2007) dedicou parte de sua obra a desmascarar essa "ideologia do gosto natural" e a tentar resgatar os vestígios de historicidade do gosto ocidental em

\footnotetext{
96 Sobre essa questão, assistir o video no youtube chamado First taste of chocolate in Ivory Coast, apontado por diversas reportagens que circularam na internet em 2014, tais como a reportagem "Produtores de cacau experimentam chocolate pela primeira vez na vida" do Correio Brasiliense, postada no site em 15/09/2014. Trecho da reportagem do Correio: "A Costa do Marfim é o maior exportador de cacau no mundo, com uma produção anual de 1,6 milhões de toneladas, que em sua grande maioria se transformam no saboroso e famoso chocolate. Mas, ironicamente, os produtores desse produto tão nobre jamais provaram o seu sabor. Em um vídeo para uma TV holandesa, foram convidadas algumas das pessoas que fazem esse trabalho árduo de colheita, secagem e ensacamento do cacau, a provar a delícia do chocolate."
} 
matéria de arte e estética em geral. Nessa medida, o autor francês procurou desfazer a separação arbitrária entre as artes consideradas mais nobres - a música, a pintura, a literatura - e as atividades cotidianas mais banais como a escolha da decoração da casa, os esportes praticados, a escolha da comida, as atividades de lazer (cinema, teatro, museu, parque), além das preferências políticas. Independentemente do domínio tratado, é fundamental entender que qualquer gosto passa por um processo de aprendizagem que acaba por definir os critérios mediante os quais serão produzidas as escolhas futuras. Assim, as preferências justapostas de uma mesma pessoa costumam ter uma coerência entre si, já que elas remetem a uma espécie de moldura cognitiva comum. Além do que, os objetos e as práticas não estão soltos. Quando o pesquisador os coloca em quadro, mediante a análise estatística, torna-se possível reconhecer a unidade por trás dessas escolhas: o estilo de vida. ${ }^{97}$ Para dar conta do estilo de vida, o autor forja o conceito de habitus, que é o mecanismo de produção das escolhas futuras, uma disposição que se faz de natural mas que foi socialmente construída e sofreu um processo de "naturalização" na espontaneidade do corpo. Para usar uma expressão do próprio autor, o gosto adquirido é a "história tornada natureza". O gosto legítimo (a "arte pura”, por exemplo) é algo que não é privilégio da natureza, da constituição natural das coisas ou da percepção humana, mas uma forma de dominação histórica. Falar de gosto e não falar de dominação é esquecer que em todo ato de julgamento existe a mobilização de esquemas cognitivos que só não são arbitrários à luz de uma história coletiva compartilhada e, portanto, "esquecida" de sua historicidade. Os esquemas do gosto são fundamentais para a construção do senso de si e da confiança em sua posição no mundo, que será qualificada como superior ou inferior de acordo com o referente humano. No contexto do mercado de cafés, nos interessa apreender como se dá a aquisição de um novo padrão de gosto. Via de regra, um barista treinado aprecia bastante a acidez presente na bebida. Às vezes, esse padrão cria uma celeuma entre o barista e o consumidor não iniciado no universo degustativo da bebida. Em um livro especializado, lemos o seguinte alerta a esse respeito:

A palavra acidez é uma alcunha que pode separar os profissionais do café

97 Analiticamente, a noção de estilo de vida refere-se ao princípio comum que define o caráter geral das escolhas individuais 
dos seus clientes. Como profissionais do café, nós precisamos usar essa palavra muitas vezes, mas procuramos usá-la internamente. Quando os clientes escutam ou usam a palavra, é tipicamente em sentido pejorativo. Eles ouvem acidez e pensam, "Minha barriga dói!". Eles pensam sobre a dureza e os sabores desagradáveis que não estão diretamente relacionados ao nível de $\mathrm{pH}$ do café; em vez disso, esses traços estão relacionados a compostos que se desenvolvem como resultado da má fabricação da bebida, do ato de se guardar um café por um longo tempo, ou da torra descuidada de cafés verdes de má qualidade. (...) Tecnicamente, quando os profissionais de café utilizam a palavra acidez, nós não estamos falando sobre o nível de $\mathrm{pH}$, mas sobre a presença de ácidos específicos que são os mesmos presentes em limões, berries, vinagres, e outros alimentos "vivos". Dito isso, os profissionais do café geralmente reverenciam esses compostos mais do que a maioria dos clientes, por isso temos de ter cuidado para que não deixar acidez pesar demais na hora de comprar um café. (FREEMAN et al., 2012) ${ }^{98}$

Acredito que esse tipo de contraste não é algo contingente presenciado apenas por alguns baristas, mas está presente em todo o processo de reestruturação pelo qual passa o mercado de cafés especiais hoje no Brasil. O processo de formação sensorial que um barista passa ao realizar um curso especializado joga luz sobre as raízes desse possível conflito. Observemos a minha experiência etnográfica no curso de barista em São Paulo. O curso de barista do Coffee Lab aconteceu entre os dias 3 e 6 de Fevereiro (2015), das 19h às 22h, no estabelecimento localizado no bairro Pinheiros. O Coffee Lab surgiu em 2008, fundado pela barista e mestre de torra Isabela Raposeiras, que foi vencedora do primeiro campeonato de baristas do Brasil, em 2002. A proposta da cafeteria é criar um espaço geral de experimentação do café, e não há dúvidas de que ela tem tido um papel central na disseminação da cultura de degustadores de cafés nos últimos anos. Segundo as palavras encontradas no site para definir o Coffee Lab:

O Coffee Lab é um laboratório de torra, degustação e preparo de cafés de qualidade, focado em micro lotes com características singulares, responsabilidade eco-social e rastreabilidade do pé ao pacote. (Site do Coffee $\mathrm{Lab})$

98 "The word acidity is a wedge that can separate coffee professionals from their customers. As coffee professionals, we need to use this word a lot, but we try to use it internally. When customers hear or use that word, it's typically as a pejorative. They hear acidity and think, 'My tummy hurts!'. They think about sharp, unpleasant flavors that actually aren't directly related to the $\mathrm{pH}$ level of the coffee; rather, they're related to compounds that develop as a result of poor brewing, holding coffee for a long time, or careless roasting of poor-quality green coffee. (...) Tecnically, when coffee professionals use the word acidity, we aren't talking about the $\mathrm{pH}$ level, but the presence of particular acids that are the same as those in lemons, berries, vinegars, and other 'lively' foods. All of that said, coffee professionals generally revere these compounds more than most of our customers do, so we have to be careful that we don't let acidity become the primary driver in our decision to buy a coffee." 
Figura 9 - O site do Coffee Lab

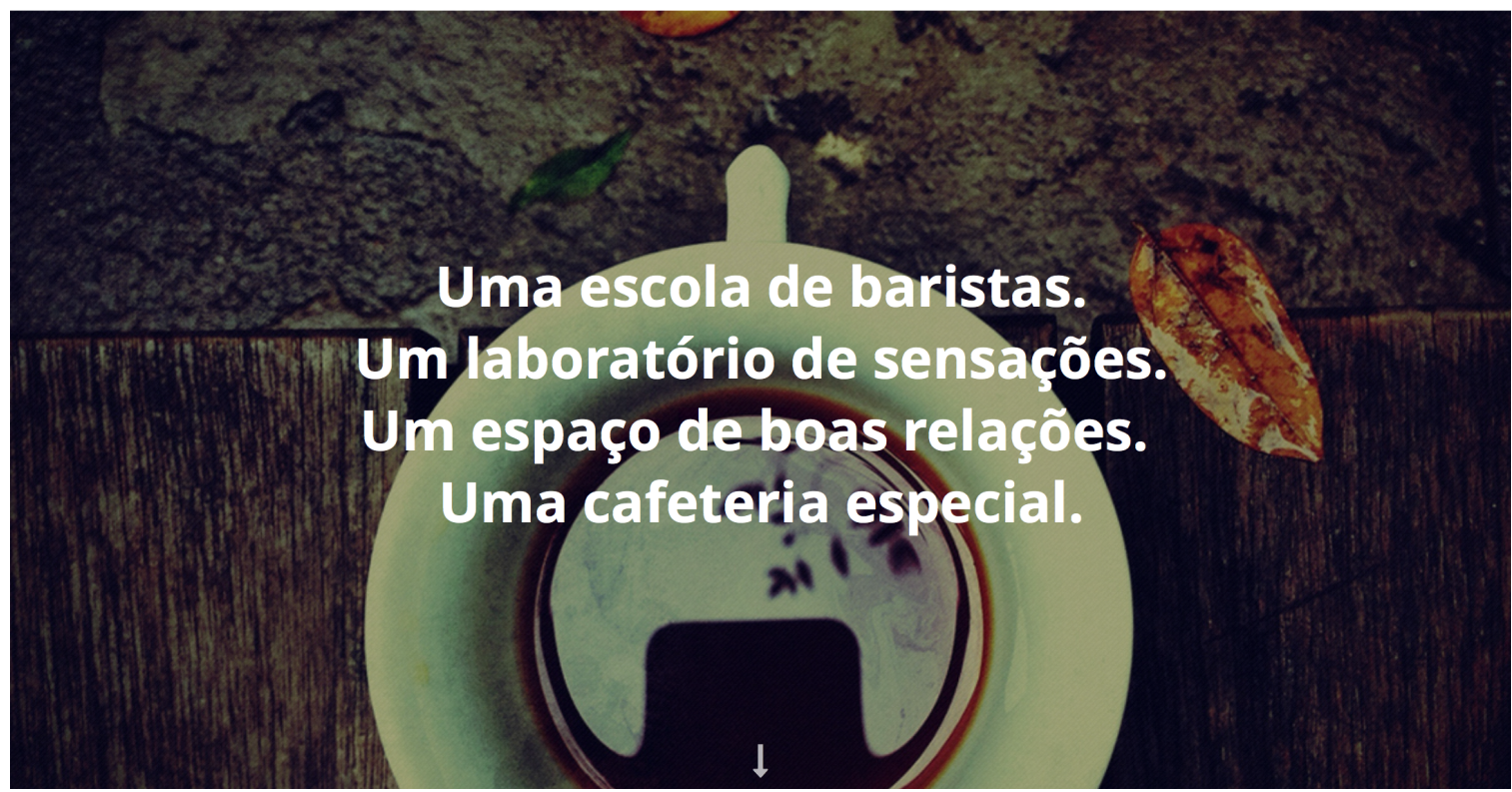

Fonte: print screen da página inicial do Coffee $\mathrm{Lab}^{99}$

A cafeteria em si fica numa casa em Pinheiros. Na entrada da casa, um corredor verde de plantas acompanha a esquadria de vidro. Dentro da casa, destaca-se a máquina de torrefação de café que faz parte da decoração e que, segundo um dos funcionários, é usada diariamente. O café é torrado ali mesmo, ao lado das mesas, e o cheiro toma conta do espaço e, às vezes, do quarteirão inteiro. Além da produção para venda e consumo na loja, o Coffee Lab torra o café também para alguns restaurantes da cidade de São Paulo e possui uma loja virtual onde se pode fazer os pedidos de qualquer lugar do mundo. Atualmente, o estabelecimento trabalha com micro-lotes provenientes de pequenos produtores do Espírito Santo, além de um blend da casa para a preparação do espresso. ${ }^{100}$ Nas embalagens de cada café é possível ler o nome do produtor, o nome do sítio, a variedade do grão (catuaí 81 , bourbon, catucaí 785, etc.), o processo (lavado, cereja descascado), o ano safra, a altitude

99 Site do Coffee Lab. Disponível em: <http://coffeelab.com.br>. Acesso em: 24 ago 2015.

100 Em 2012, uma reportagem do Estadão já apontava o microlote como "um caminho irreversível”. O então presidente da Associação Brasileira de Cafés Especiais (BSCA) dá a seguinte justificativa: "O café como produto de gastronomia passa pelos microlotes: é um nível de detalhamento necessário para uma abordagem gastronômica" (LUPINACCI, Heloisa. "O microlote é um caminho irreversível”. Estadão, Paladar, 13 dez. 2012). 
do sítio e uma descrição sensorial "O que a equipe acha dele". A descrição sensorial do catuaí 81, por exemplo, é a seguinte: “é basicamente uma cheese cake de goiaba na xícara segundo os baristas do Lab. Esse tom de frutas com a textura láctea deixam este grão delicioso". No cardápio da cafeteria, as opções de comida são enxutas, como a maioria dos estabelecimentos essencialmente focados em café. O cardápio, no entanto, é bem grande. Ele é repleto de bebidas à base de café, além de ter uma seção intitulada "Rituais". O propósito da seção é incentivar o consumidor a perceber as nuances dos diferentes tipos de preparo do café e do uso de diferentes matérias-primas. A descrição da seção é a seguinte: "Desenvolvemos uma série de rituais lúdicos e saborosos porque queremos que você faça as mesmas descobertas que um dia todos nós, barista do Coffee Lab, fizemos. Divirta-se!”. Um detalhe interessante é que se você chegar no estabelecimento e disser que é a sua primeira vez, eles trazem imediatamente o Ritual 1, que consiste no preparo de dois cafés pelo mesmo método, um feito com uma marca comum de supermercado e o outro feito com um café especial. Também entre os rituais estão as diferenças no sabor do café conforme a interação com os alimentos, a chamada "harmonização", no caso com queijo e chocolate. Os rituais procuram emular uma situação experimental de laboratório (daí o Lab no nome), na qual todos os parâmetros são controlados e apenas se muda a variável a ser testada, comparando-se os resultados obtidos. Também dessa forma é possível incitar o desenvolvimento da degustação como modo de apreensão das coisas entre os consumidores da casa que passarem pelos rituais de iniciação. 
Figura 10 - Fotografia do cardápio do Coffee Lab



Fonte: elaborada pelo autor

A primeira aula do curso de barista, ministrado por Renato Gutierres, focou nos princípios gerais de degustação do café - degustação que, segundo Gutierres, tem sempre a ver com "o que é qualidade no café". Nas suas palavras, "o café deixou de ser uma bebida funcional e passou a ser apreciado por outros motivos" e, portanto, é preciso que nós desenvolvamos uma capacidade de julgar a xícara pelo que ela é e não apenas com base no gosto pessoal. Em seguida, fomos expostos aos elementos passíveis de serem analisados numa degustação de café: aroma, sabor, acidez, corpo, doçura, sabor residual, defeitos, amargor e adstringência. Para facilitar a aprendizagem dos alunos, Gutierres tentou desenvolver um repertório de associações que estabelecemos com cada um dos componentes da degustação — o que resultou na montagem dos esquemas abaixo, dentre outros: 
Figura 11 - Anotações da primeira aula no Coffee Lab
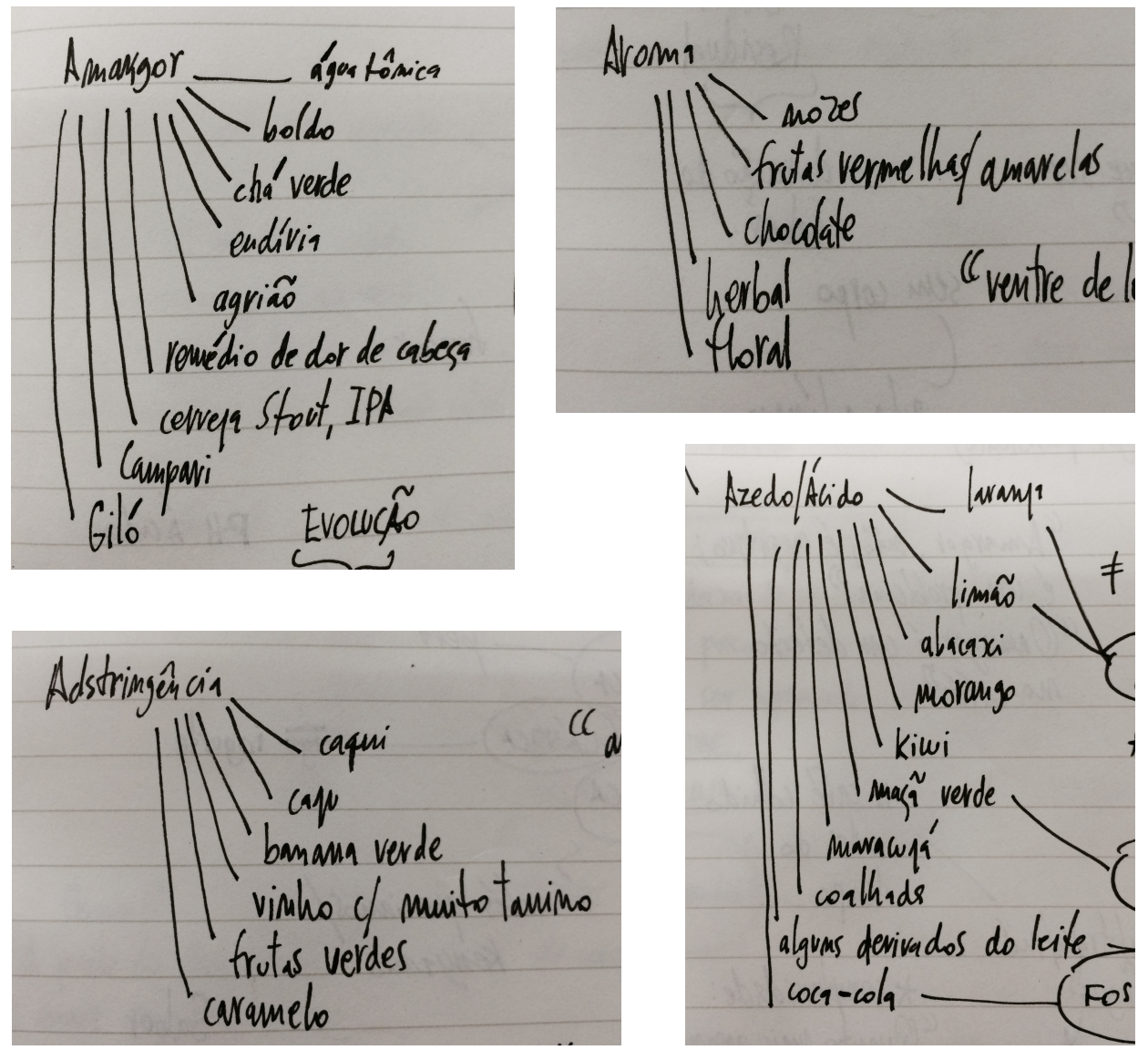

Fonte: elaborada pelo autor

Figura 12 - Folha explicativa recebida no primeiro dia de aula

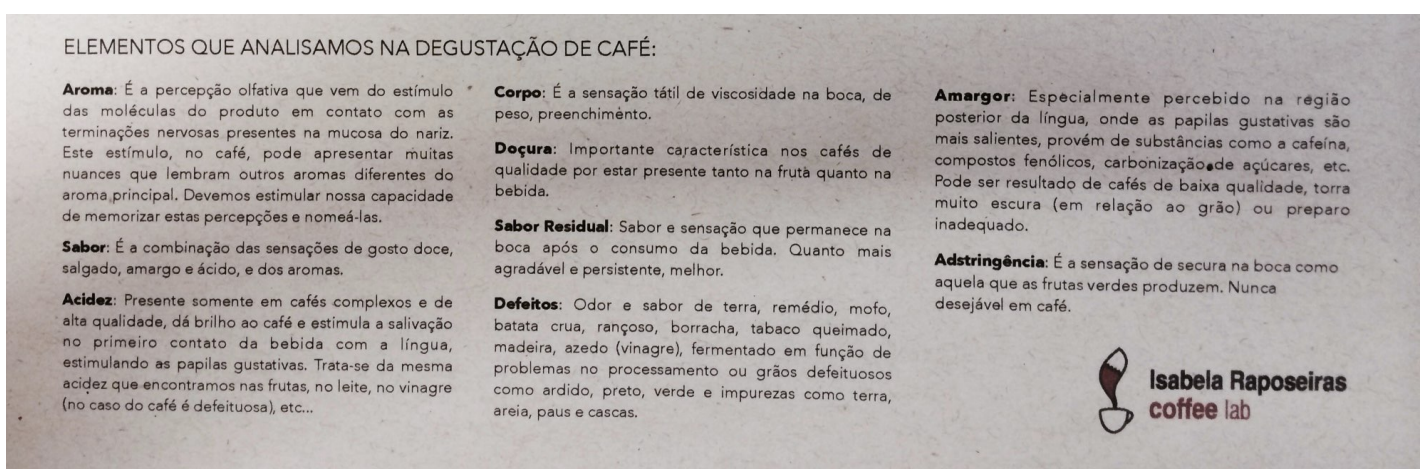

Fonte: fotografia tirada pelo autor 
Um dos pontos mais marcantes (e polêmicos) proposto pelo modelo de degustação do Coffee Lab foi a questão da repreensão do amargor no café. Renato repetiu várias vezes que "o amargor é um defeito no café", "amargor não, isso é negativo, é um problema”. A princípio, tal afirmação soou estranha porque nós estávamos acostumados, enquanto consumidores, a associar o café ao sabor amargo e isso não constituía um problema, fazia parte da coisa. Inclusive, há um famoso provérbio italiano no mundo do café que diz o seguinte:

Il caffè, per essere buono, deve essere nero come la notte, forte come un peccato, dolce come l'amore e caldo come l'inferno.

Podemos observar aqui, de uma forma indireta, a valorização do amargor como sabor essencial do café, já que ele tem que ser "forte" e "preto", características comumente associadas ao amargor. A contraposição desse preceito ao modelo de degustação disseminado pelo Coffee Lab torna-se mais evidente se atentarmos para a trajetória da proprietária Isabela Raposeiras. Antes mesmo de montar a cafeteria, Isabela havia visitado a Escandinávia e havia se encantado pela forma com que eles preparavam o café, acentuando notas mais florais e frutadas, em contraste com o estilo italiano que privilegia notas mais fechadas. É importante lembrar que foram os países nórdicos europeus que desenvolveram a profissão de barista tal como a conhecemos hoje, a exemplo do norueguês Alf Kramer, criador do Campeonato Mundial de Baristas, que teve sua primeira edição em 2000, e da também norueguesa Erna Knutsen, que foi a primeira pessoa a utilizar a expressão "Specialty Coffee", em 1974, numa edição do Tea \& Coffee Trade Journal. Em suma, a tendência nórdica é privilegiar os grãos de torra clara e que produzem um café mais aromático e ácido, em detrimento do amargor. Esse contato da Isabela Raposeiras com o universo nórdico da bebida fez com que a brasileira passasse a associar o amargo a um defeito no café, conhecimento que passou adiante para o seu aprendiz Renato Gutierres e, consequentemente, para nós, alunos do curso de barista do Coffee Lab. Em uma entrevista, Isabela Raposeiras explicou a diferença entre as duas principais escolas de barismo no mundo. Em suas palavras, a escola original (italiana) é extremamente tradicional, é o grande começo de tudo, onde surgiu a máquina de espresso. Já a escola 
internacional "é uma escola em formação, que alia muito a técnica ao resultado. O foco é o melhor café que se pode conseguir. Países como Japão, Inglaterra e a região escandinava estão dando ótimos exemplos de como trabalhar a nova escola". ${ }^{101}$ Fica evidente que a barista e empresária se aproxima mais da última escola de barismo. Essa vinculação se tornou patente também numa das falas de Renato, ao dizer que "por incrível que pareça, a Itália não entende muito de café", ou também quando disse que "na Itália, eles servem de tudo". Renato também contou a história de um italiano que veio fazer o curso no Coffee $L a b$ e que, ao provar o café de lá, disse que parecia mais que "colocaram sal no meu café". Ora, entender o conflito entre esses dois padrões globais de gosto que aterrissaram no Brasil, é de fundamental importância para a presente pesquisa. Esse conflito também encontra terreno no cotidiano das cafeterias, na medida em que, historicamente, o brasileiro possui um estilo de preparo de café mais próximo ao modelo italiano.

Figura 13 - O ranking mundial de consumo de café por pessoa

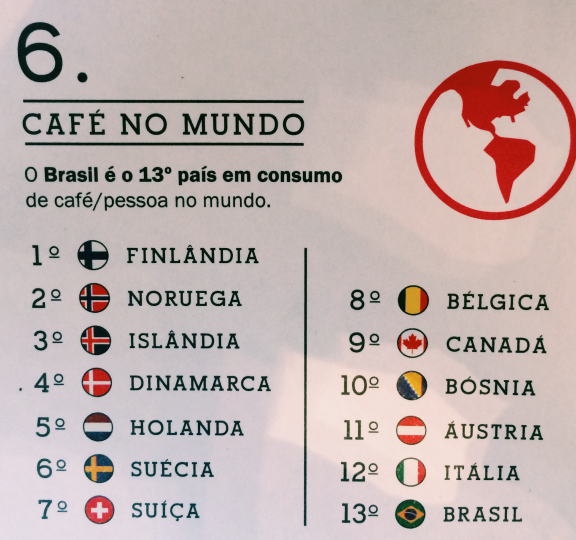

Fonte: tabela informativa distribuída na cafeteria Suplicy

Dentre as coisas faladas por Renato nas aulas, nada soava mais confortante do que o enaltecimento das potencialidades abertas pelo caminho da degustação - para ele e para o Coffee Lab "a parte da degustação é a mais importante em todo o universo cafeeiro". 102

101 ROCHE, Marco de la. "Entrevista com a barista Isabela Raposeiras". Mixology News, 23 jan. 2013.

102 Renato também gosta de falar que "cada gole que você dá é uma despedida”, já que você nunca mais vai encontrar aquela configuração sensorial outra vez. 
Numa das aulas, ele disse que enquanto o vinho e a cerveja têm milhares de anos de tradição e de definição da gama sensória adequada, o café como bebida tem apenas 500 anos, 60 a 80 anos de cafés especiais. Em suas palavras, "isso é bom porque a gente pode fazer o que quiser, nesse nível”. No entanto, ao mesmo tempo, também havia uma série de injunções protocolares nas aulas, como a de que "amargo é defeito" ou a ideia de que o gosto deveria ser "guardado no bolso", na medida em que precisamos aprender a "avaliar tecnicamente" o café. O que significava esse "avaliar tecnicamente"? Significava seguir determinado protocolo sobre como classificar o paladar humano? Como fica a abertura para a experimentação de sabores se você tem um protocolo em mãos sobre o que deve ser evitado e o que deve ser apreciado numa degustação? Essas contradições são inerentes ao discurso do estabelecimento que se propõe, ao mesmo tempo, ser um laboratório de sensações e um laboratório de estudo científico do grão. ${ }^{103}$ De qualquer jeito, para desenvolver a capacidade de degustar o café era preciso construir um repertório, uma espécie de memória das nossas associações sensórias. Renato frisava que isso era um processo, você aprende a degustar as coisas "chocando as informações entre si", e uma das dicas passadas para nós foi a de visitar o mercado municipal de São Paulo e provar tudo que fosse oferecido, replicando o modelo de degustação para a comida em geral.

No que diz respeito à profissão barista, Renato disse que não se trata apenas de aprender a fazer um bom café, é preciso se empenhar para ajudar a "criar uma cultura de consumo nova", uma cultura que tem a ver com essa injunção de degustação. Todavia, essa questão de tentar converter as pessoas para um novo padrão de consumo não passava isenta de dilemas morais na consciência do instrutor. Ele nos contou que, no começo, ele sentia um peso na consciência: "eu to falando que o café que as pessoas tomam é ruim”. Mas depois de trabalhar um tempo com aquilo, ele disse que se sentiu melhor porque passou a pensar: "não, eu tô melhorando a vida dessas pessoas". Assim, por mais que o trabalho do barista fosse sempre difícil, há um "retorno imediato", em suas palavras, pois "cada xícara bem feita você recebe no mínimo um sorriso de volta". Além do que, um dos trabalhos do barista também é "saber com quem você está falando" na hora de preparar o café, porque

$103 \mathrm{Na}$ aula de preparo de espresso, impressionado com a complexidade de parâmetros mobilizados, cheguei a comentar que aquilo era mesmo "uma arte", mas logo fui corrigido pelo próprio Renato: "não, não é arte, é ciência”. 
assim você pode fazer um café que se adeque mais ao perfil de cada tipo consumidor. Aqui, em tese, o barista é uma espécie de sociólogo prático, já que precisa desenvolver a capacidade de discernir os tipos consumidores que frequentam a cafeteria, saber se é o caso de um "coffee snob", de um consumidor acostumado com o "café de padaria" ou daquele cliente específico que gosta do café de tal ou tal jeito.

Esse preceito de tentar entender o perfil de cada consumidor não costuma ser seguido pela maior parte dos baristas e atendentes das cafeterias. Até porque no caso brasileiro o coado está presente nas casas brasileiras há mais de século, enquanto as cafeterias vêm conquistando espaço há não mais de duas décadas. As cafeterias, portadoras do novo, trazem o apelo para o espresso, num primeiro momento, e para os cafés especiais, num segundo momento. São dois contrapontos sensórios ao café coado tradicional da casa brasileira. O espresso, de sabor concentrado, azedo e denso, diferente do sabor mais cristalino, amargo e queimado do coado caseiro. Os cafés especiais, cuja "especialidade" valoriza as características que o grão absorveu no processo de cultivo, especialmente a acidez adquirida em terrenos de elevada altitude, também é bastante diferente do coado tradicional. Os baristas costumam ser os portadores da novidade, o que muitas vezes toma a forma do gosto pela distância em relação ao padrão de gosto mais tradicional. Eric Laurieur, geógrafo do Reino Unido que realizou etnografias em cafeterias da rede britânica Caffé Nero, desenha a figura do tipo de consumidor que é percebido pelos baristas como sendo mais próximo do saber técnico e especializado: "quando um cliente pede um ristretto, então esse alguém é sério sobre o seu café. Poucos clientes vão pedir e devemos pensar nesse cliente como aquela pessoa que chega em um bar e pede um uísque de 40 anos de malte único. Certifique-se de fazê-lo corretamente, tome o seu tempo e, definitivamente, jogue fora se o café sair ruim". ${ }^{104} \mathrm{O}$ consumidor de ristretto, que é um espresso curto de 15 a $20 \mathrm{ml}$, aparece frequentemente associado a um tipo de consumidor

104 "When a customer orders a ristretto, then this is someone who is serious about their coffee. Few costumers will order it and we should think of it as a person at a bar ordering a forty year old single malt whiskey. Make sure you make it correctly, take your time and definitely throw it away if it comes out bad." (LAURIER, 2003, pg. 9) 
mais exigente e conhecedor das nuances da bebida. ${ }^{105} \mathrm{O}$ consumidor de ristretto teria como extremo oposto aquele consumidor de shakes à base de café nas redes da Starbucks (frappuccinos), que abusam do chantilly e das caldas de chocolate. Se conseguimos imaginar uma cafeteria frequentada por diferentes tipos de consumidor (com diferentes preferências sensórias), a questão também se estende para os diferentes países consumidores, onde cada país possui um tipo de consumidor característico:

Os consumidores de diferentes países mostram diferenças marcantes na apreciação da proporção de amargura e acidez. Nos países do sul da Europa, os consumidores preferem um café espresso com predominância de amargor (e consideram o corpo muito importante), enquanto, nos consumidores do norte, um sabor mais equilibrado é preferido e excesso de amargor é considerado um defeito. Isso ocorre também na concentração da xícara de café espresso, muito pequeno e concentrado no sul, onde é bebido sem leite; mais diluído e, frequentemente, com leite ou creme de leite no norte. (ILLY \& VIANI, 2005. pg. 302-303) $)^{106}$

Sabemos que foram os italianos que definiram os parâmetros de preparo do espresso e que exportaram esse conhecimento para os países da economia globalizada, junto com a infraestrutura desse conhecimento, as máquinas de espresso (Gaggia, Saeco, Bianchi, LaSpaziale, Illy, De’Longhi, Astoria, Lavazza, Ulka, Italian Coffee, Marzocco, La Pavoni, Ascaso, Nuova Simonelli, La Cimbali, etc.). Já quando falamos do alargamento do conhecimento técnico da bebida ao ponto de abranger também o plano da degustação, costuma-se dizer que foram os escandinavos que desenvolveram a profissão barista. $\mathrm{O}$ norueguês Alf Kramer criou o World Barista Championship (WBC) ${ }^{107}$ em 2000, seguindo

105 Em 2011, uma propaganda da Nespresso participa dessa forma de tipologização dos consumidores. O ator George Clooney, sem querer, troca a mala no aeroporto com uma mulher. Ao chegaram em seus hotéis, os dois abrem as malas e percebem que elas estão trocadas; a câmera dá destaque para as cápsulas da Nespresso dentro da mala de ambos. A dela deveria conter as cápsulas Volluto, enquanto a dele, cápsulas Decaffeinato. Ao combinarem um lugar para trocar de volta as bagagens, eles optam por uma loja da Nespresso. A mulher, ao vê-lo, sabendo que ele é o ator famoso George Clooney, diz que o imaginava diferente. Então ele pergunta, "mais alto?". Ela responde "Não, mais... ristretto". Logo em seguida, entrega a máscara de dormir que também estava na sua mala e se despede dizendo "Goodbye, $M r$. Decaffeinato" — "Até logo, Sr. Descafeinado". O ristretto aparece aqui, na simbologia da propaganda, como associado à virilidade e a um tipo de consumidor mais maduro.

106 "Consumers in different countries show marked differences in the appreciation of the ratio of bitterness to acidity. In southern European countries, consumers prefer an espresso with a bitter dominance (and consider body very important), while in the northern ones a more balanced taste is preferred and excess bitterness is considered a defect. This stems also from the concentration in the espresso cup, very small and concentrated in the south, where it is drunk without milk; more diluted and frequently with milk or dairy cream in the north."

107 Campeonato Mundial de Barista. 
o formato do campeonato norueguês de barista, que existia desde 1998. Um dos principais objetivos do WBC é "promover o conhecimento e o consumo de cafés especiais pelo consumidor através do barista" 108 , portanto, servir como uma ferramenta de marketing para esse segmento de mercado. Outro objetivo é fornecer padrões de preparo para baristas a nível mundial, que pode funcionar como forma de iniciação ao treinamento técnico. Em um artigo intitulado "The Future of the World Barista Championship" (2006), Tim Wendleboe, barista que havia ganhado o WBC de 2004 e que, em 2007, abriu uma cafeteria e micro-torrefadora em Oslo (Noruega), reclama do excesso de padronização das regras da competição. Segundo Wendleboe, elas implicam no enfraquecimento do gosto (paladar) como parâmetro final e na ampliação dos parâmetros técnicos e operacionais. Os parâmetros vão desde o tempo padrão de extração (20-30 seg), passando pelo tempo de persistência da crema (pelo menos $30 \mathrm{seg}$ ), e chegando no entendimento de que o amargor é um defeito no café. ${ }^{109}$ Como o campeonato foi criado por noruegueses, acabou que as premiações e as regras do concurso, com o passar dos anos, contribuíram para legitimar o tipo de gosto que já prevalecia nos países nórdicos: um café com menos corpo e características mais frutadas e florais. A opinião de Wendleboe, doravante, é confluente com as teses da chamada terceira onda do café, já que apela para a flexibilização dos modos de preparo da bebida:

$\mathrm{Na}$ minha opinião, o fato de que existem muitas maneiras diferentes de servir e preparar as bebidas à base de café espresso é o que faz a cultura espresso tão interessante. Preparar e servir espresso é um artesanato [craft]. Se nós estabelecermos muitas regras para esse ofício, os baristas vão acabar se tornando máquinas automáticas em vez de se tornarem criativos, experientes e apaixonados. (...) Pegue uma folha de pontuação técnica, por exemplo. Será que realmente precisamos julgar os baristas tecnicamente? De que forma as qualidades técnicas importam se o espresso conseguir sair com um excelente sabor? Será que o cliente se importa sobre a técnica do barista? (...) Na minha opinião, isso é impossível julgar como "correto", já que existem muitas formas de se dosar o café em todo o mundo; eu prefiro usar diferentes dosagens dependendo do café que eu uso e do sabor que eu quero

108 Cf. "The Future of the World Barista Championship", Tim Wendleboe, 2006.

109 Quanto à proporção de água para café (coffee-to-water ratio), a medida usada pela Specialty Coffee Association of America (SCAA) é geralmente tomada como referência; a SCAA Golden Cup Ratio usa 55 gramas de café por litro de água, ou 9-11 gramas de café para cada xícara (cup), que contém mais ou menos $170 \mathrm{ml}$ (6 ounce). 
criar." (WENDELBOE, 2006) $)^{110}$

Na fala de Wendleboe, podemos observar uma valorização da degustação como sendo o parâmetro final da profissão do barista. Da mesma forma que no segmento dos foodies, aquele estilo de vida preocupado em descobrir boas comidas, há aqui uma obsessão pelo componente estético do gosto, acima de qualquer questão de natureza cerebral ou mecânica. Ora, o incômodo do autor norueguês é dirigido à normatização do gosto desencadeada por esses campeonatos internacionais. Até porque, no âmbito do mercado, os modelos são copiados. Para competir hoje no campeonato mundial, o barista deve primeiro se qualificar no campeonato de seu próprio país, que geralmente segue o modelo do WBC. Segundo o site da Associação Brasileira de Café e Barista, o campeonato de barista "é hoje o principal foco das atenções nas feiras mundiais de cafés especiais. Neste campeonato o barista tem 15 minutos para preparar e servir aos juízes: 4 espressos, 4 capuccinos e 4 drinques de assinatura". ${ }^{111}$ No Brasil, o Campeonato Brasileiro de Barista surgiu em 2002, sendo Isabela Raposeiras (hoje dona do Coffee Lab) a primeira vencedora da competição. Os campeonatos, tanto o de barista, quanto o de grão de café (Cup of Excellence), surgem como instâncias de normatização do espaço degustativo mais amplo, na medida em que lotes e baristas premiados vão agregar valor aos negócios que eles tomam parte. Na opinião de Michael Phillips, sócio-proprietário do Handsome Coffee Roasters e barista campeão do WBC de 2010, isso funciona da seguinte forma: "As competições de barista são a cara que o segmento de cafés especiais tem para oferecer, a linha de frente do que estamos fazendo numa espécie de frente unificada. É uma chance para nós dizermos à mídia 'Ei, olhem isso. Olhem para o que nós prestamos atenção, o que

\footnotetext{
110 "In my opinion, the fact that there are so many different ways of serving and preparing espresso based drinks is what makes the espresso culture interesting. Preparing and serving espresso is a craft. If we set too many standards for this craft, the baristi will end up becoming a super automatic machine instead of being a creative, knowledgeable and passionate barista. (...) Take the technical score sheet for instance. Do we really need to judge the baristi technically? What do technical qualities matter if the espresso tastes excellent anyway? Does the customer care about the technique of the barista? (...) In my opinion this is impossible to judge as 'correct' because there are so many ways of dosing practiced throughout the world and I prefer to use different ones depending on the coffee I use and the flavor I want to create."

111 Site da ACBB.
} 
é importante para nós, e como somos legítimos"". ${ }^{112}$ Doravante, por mais que tenha a degustação como diretriz, todo barista acaba funcionando como um catalisador das novas tendências em matéria de gosto (gustibus) do café. Sua prerrogativa de perito técnico o torna também uma espécie de árbitro do sensível, definindo a legitimidade das preferências de consumo que o dia-a-dia da cafeteria coloca em jogo ao conviver com diferentes tipos de consumidores.

A habilidade de experimentar o alimento é algo que requer não apenas treino, mas contextos específicos para a sua realização. A autora Annemarie Mol (2012) argumenta que diferentes contextos podem implicar diferentes formas de se experimentar um alimento, que servem a diferentes propósitos. Por exemplo, o amargor, para algumas tradições da biologia, possui uma função de sobrevivência para a espécie, na medida em que detectaria os alimentos venenosos a serem evitados. ${ }^{113}$ Provar um alimento para ver se este está estragado teria o mesmo significado. $O$ fato de que existem pessoas que gostam do amargor, numa xícara de café, por exemplo, constitui um problema para essas teorias, porque elas defendem que o gosto se adequa à função de sobrevivência. A resposta para a persistência desse fato bio-social é, portanto, improvisada. Partindo de uma aversão natural ao amargor, o ser humano desenvolveria formas de contornar essa natureza através do domínio cultural do próprio corpo. ${ }^{114}$ Segundo a autora, as pesquisas que corroboram essa ideia da aversão natural se baseiam em testes de laboratório, em que animais (ratos, no caso) são colocados em situações artificiais de estimulação. Nesse contexto, é possível que os animais desenvolvam uma habilidade de inspecionar novos alimentos, já que eles foram forçados a conviver com uma gama reduzida de opções. A concepção da autora é clara: "Em laboratórios, ratos não podem fugir" (MOL, 2012, pg. 122). ${ }^{115}$ Por consequência, os resultados dessas pesquisas não dependem apenas do corpo dos ratos, mas de todo o

112 "Barista competitions are the face that specialty coffee has to offer as to the high end of what we're doing in sort of a unified front. It's a chance for us to say to the media 'Hey, look at this. Look at what we pay attention to, what's important to us, how legitimate we are"'. A Film About Coffee. [filme] Direção: Brandon Loper. Avocados \& Coconuts, 2014. Red Epic, $67 \mathrm{~min}$.

$113 \mathrm{Na}$ mesma lógica de raciocínio, o doce indicaria a presença de calorias na forma de açúcar, enquanto o umami indicaria a presença de proteínas, por essa razão, ambos os sabores ativariam uma resposta positiva no cérebro.

114 Por exemplo, na divulgação de uma pesquisa sobre as implicações do amargor na comida lê-se: "A aprendizagem pode sobrepor-se às aversões inatas. Você pode aprender a gostar das coisas."

115 "In a laboratory rats cannot run away". 
contexto da pesquisa: das gaiolas, dos esquemas de alimentação, das questões de pesquisa, etc. Em conjunto, todos esses elementos constituem uma forma altamente específica de arranjo socio-material. É a partir desse arranjo que a habilidade de experimentar alimentos (tasting) ganha uma existência específica e torna-se cientificamente relevante para os propósitos do laboratório. ${ }^{116}$ No entanto, sabe-se que algumas espécies são dotadas de uma maior abertura para os processos de aprendizagem; é o caso do rato, é o caso do humano. Para esses tipos de animais abertos ao mundo, a própria prática é que ensina o que gostar e o que recusar em matéria de alimento. A habilidade de provar (tasting) e não apenas engolir o alimento é um desenvolvimento possível das situações de ordem prática. Da mesma forma, os arranjos socio-materiais que nos ajudam a decidir o que comer e como comer são infinitos. Nesse sentido, o tipo de degustação gastronômica mobilizada pelos baristas e pelos consumidores iniciados no segmento gourmet é apenas uma das formatações do ato de experimentar comida, por mais que atualmente ele se destaque dos demais:

Em algumas situações, como no laboratório, a degustação pode ser mobilizada como uma técnica para detectar veneno. Em outras, ela pode ser mobilizada como uma técnica para especificar a proveniência de tudo o que é que se está provando. Isso demonstra que a degustação não é uma habilidade natural e e só pode ser aprendida em circunstâncias bem específicas. Só quando são colocados reiteradas vezes numa mesma "situação adequada" é que os connoisseurs de vinho podem se tornar capazes de discernir que vinho está sendo derramado em seus copos. Algo semelhante ocorre com os amadores de café. Se você investir o suficiente naquilo e se você tiver acesso às "coisas" certas e aos outros amadores com quem possa conversar sobre isso, você pode gradualmente afinar suas habilidades de percepção. Dessa forma, você pode aprender a provar qual café vem da Nicarágua e qual deles é Etíope. Diferenciar o arábica e o robusta é fácil! Fora que a degustação de especialistas não se limita ao nariz e à boca. Ela também depende de olhos que observam e de dedos que tocam. Mais longe ainda: ser um "expert" não envolve apenas treinar os sentidos. É também fundamental aprender a fazer um bom café. Nesse quesito, conhecer vendedores que estejam conectados a bons produtores é indispensável. Assim também deve ser com o equipamento. Todo tipo de detalhe sobre o processo de torrefacção, de moagem e de preparo deve ser perpassado. Finalmente, depois de passar por tudo isso, você pode degustar cuidadosamente em sua xícara essa bebida complexa, densa e amarga na medida certa. (Não ouse estragar a sutileza do sabor com açúcar!) (MOL,

116 Tasting: o ato de se provar, experimentar, degustar um alimento. 
2012, pg. 124) $)^{117}$

Por muito tempo, acreditou-se que o amargor do café era proveniente basicamente da cafeína. Uma pesquisa recente, conduzida por químicos alemães e norte-americanos, aponta que apenas $15 \%$ do amargor da bebida provém da cafeína. ${ }^{118}$ Descobriu-se que a maior parte do amargor provém na verdade de compostos fenólicos liberados quando os grãos são torrados. Há duas classes principais desses compostos: as lactonas de ácido clorogênico e os fenilindanos. A primeira classe é predominante nos grãos de torra mais clara e média, enquanto que a segunda classe é mais encontrada nos grãos de torra escura. Em termos sensoriais, um sabor amargo mais persistente e severo é característico das segundas substâncias, que são resultados da quebra química das primeiras. Com o tempo, descobertas como essas são incorporadas aos modos de degustação dos baristas mais especializados, quando eles procuram perceber as diferentes formas de amargor e acidez na bebida - o que pressupõe um grau de refinamento gigantesco. É interessante observar que Thomas Hofmann, um dos autores dessa pesquisa sobre os compostos químicos do amargor, diz que a descoberta servirá para tentar reduzir o amargor presente na bebida industrialmente produzida. ${ }^{119}$ Ironicamente, o próprio autor confessa, no entanto, que é um ávido consumidor de café e que tem preferência pelos grãos de torra escura, justamente

117 "In some situations, or so we saw in the laboratory, 'tasting' may be mobilised as a technique for detecting poison. In others it may be mobilised as a technique for specifying the provenance of whatever it is that one is tasting. This i not a natural skill and it can only be learned in quite specific circumstances. Only by putting themselves in an 'appropriate situation' over and over again may wine connoisseurs hope to come to be able to discern which wine is being poured into their glasses. Something similar goes for amateurs of coffee. If you invest enough in it and if you have access to qualified 'stuff' and other amateurs with whom you may talk about it, you may gradually attune your perceptual abilities. Thus, you may learn to taste which brew comes from Nicaragua and which other is Ethiopian. Differentiating Arabica and Robusta is easy! And expert tasting is not confined to nose and mouth. It is also depends on observant eyes and touching fingers. Stronger still: being 'in the know' does not simply involve training one's senses. It is also crucial to learn to make coffee that taste good. Here, well-connected sellers who know interesting growers are indispensable. So, too, is suitable equipment. All kinds of details of the process of roasting, grinding and brewing may be scrutinised, one by one. Then, at the end of all this, you can carefully pour complex, thick tasting, just nicely bitter, and altogether miraculous drink into your cup (Don't even dream of spoiling its superb and subtle taste with sugar!)."

118 SAMPSON, Mark T. "Battling bitter coffee -- chemists vs. main source of coffee bitterness". American Chemical Society, August 212007.

119 Pesquisadores do Institute of Food Technologists (IFT) também estão trabalhando para bloquear, diminuir ou mascarar o amargor presente em diversos alimentos. Não apenas o café, mas muitos alimentos apresentam um sabor amargo: o brócolis, o espinafre, o aspargos, o couve-flor, o couve de Bruxelas, a uva, o chá, a soja, etc. Segundo alguns pesquisadores, há uma oportunidade de mercado para atenuar a percepção do amargo e aumentar a palatabilidade de alguns alimentos entre os consumidores (Redação Institute of Food Technologists. "Food scientists working to diminish, mask bitter tastes in foods". Institute of Food Technologists, June 24 2014). 
aqueles que possuem um amargor mais severo. Detalhes como esses demonstram em que medida os padrões de gosto estão sendo negociados nos contextos que circundam o processo de produção e análise dos alimentos, de uma forma geral. Seja através da manipulação tecnológica dos alimentos para se adequar ao paladar do consumidor regular, seja mediante o simples fato de que "é possível aprender a gostar do amargo" (MOL, 2012), as situações de mercado, antes e depois da produção da coisa em sentido estrito, funcionam como contextos em que diferentes modos de degustação são acionados, a título de sobrevivência, de conveniência ou de prazer gastronômico.

Na montagem de um padrão de gosto (como o gosto pelo amargo), existem vários componentes que entram em ação. Primeiro de tudo, a questão da construção social da memória que informa o gosto. A noção de gosto que estamos falando aqui é a da forma que antecede a prática, isto é, uma disposição, uma propensão a apreciar uma classe de coisas, antecipando-se às contingências de cada encontro com o mundo. Trata-se da noção de gosto tal como aparece na expressão "eu gosto disso e não daquilo", no conjunto das preferências pessoais; não se trata do gosto como sensação sentida passivamente pelo sujeito, isto é, como paladar: as papilas gustativas recebendo o objeto. Para as ciências sociais, o gosto nunca pode ser concebido como resultado direto das características materiais de um objeto, ao contrário de outros campos disciplinares, nos quais essas características podem inclusive ser mensuradas em laboratório. Todavia, o componente material não pode ser esvaziado de importância. Caso contrário, nós não seríamos capazes de visualizar a categoria de conflito apreendida no nosso trabalho de campo nas cafeterias. O construtivismo radical diria, por exemplo, que a "qualidade dos alimentos" é uma ilusão e que depende apenas do referencial de valores compartilhados por um grupo de pessoas. ${ }^{120}$ Nós consideramos essa perspectiva insuficiente. Os esquemas da cultura só existem em contextos ecológicos específicos; não são nunca categorias puras do entendimento, mesmo quando nós as qualificamos historicamente. Qualquer referencial herdado no seio de uma coletividade faz parte de um arranjo maior que é sempre circunstancial: produtos, grupos, competências, dispositivos técnicos, gestos, contextos,

120 Essa perspectiva está presente em autores tão diversos como Michel Foucault, Clifford Geertz e Niklas Luhmann. 
etc. Nesse sentido, a noção de gosto torna-se uma encruzilhada metodológica. Seguiremos aqui a sugestão dos autores Teil e Hennion (2004), que pensam o gosto como uma prática em construção: "não seria o gosto, acima de tudo, um trabalho acerca do que é o gosto? (2004, pg. 22). ${ }^{121}$ Trata-se de um contexto no qual os agentes humanos negociam as determinações mesmas de suas preferências pessoais mediante a mobilização de coordenadas diversas em situação de teste localizado. Segundos os autores, um tipo de performance se realizaria em uma série de níveis: o gosto como uma propriedade da coisa testada; o gosto como um processo coletivo; o gosto como resultado de uma plataforma tecnológica; o gosto como um atributo próprio do apreciador (taster); etc. Em suma, quatro variáveis estariam em jogo: coisa, corpo, técnica e coletivo. ${ }^{122}$ No campo que nos interessa, essa mudança de perspectiva pode repercutir nas escolhas analíticas de apreensão do consumo gourmet. Assim, os quatro eixos citados entrariam simultaneamente na estruturação da permanência dos hábitos alimentares. Isso implicaria no abandono de metodologias mais dualistas que operam exclusivamente no âmbito do sujeito ou do objeto para falar de comida:

Uma revisão sistemática e crítica das pesquisas mais proeminentes sobre o assunto revelou que, quando se trata do estatuto dos produtos ligados ao gosto, as várias disciplinas são divididas, de uma maneira insatisfatória, entre os dois extremos do eixo natureza-cultura: ou os produtos alimentares são apenas coisas e suas propriedades são analisadas através de testes de laboratório e mensurações; ou eles são simplesmente signos, o meio [media] que serve os vários ritos e os mecanismos da identidade social, e assim sua realidade física desaparece da análise. Em nossa opinião, essa dualidade é prejudicial na medida em que elimina o próprio objeto de pesquisa, que é o gosto [taste], ou seja, ela obscurece a inevitável incerteza sobre os efeitos que surgem, sobre a natureza do acoplamentos, sobre a pertinência variável do produto experimentado em circunstâncias de degustação através de um degustador [taster], e, de modo mais geral, sobre a heterogeneidade sistemática dos elementos envolvidos nas preferências e nos hábitos. (TEIL

121 "is taste not, above all, a work on what taste is?".

122 A partir daí podemos fazer algumas indagações epistemológicas. O social (como instância primordial das relações humanas) é algo que atravessa essas quatro dimensões ou ele deve ser reduzido ao componente da herança cultural de uma coletividade delimitada - o que implica na manutenção da noção enfática de cultura como conjunto de significados coletivamente compartilhados? 
\& Hennion, 2004, pg. 19-20) ${ }^{123}$

Essa contribuição nos ajuda a entender melhor o papel que a ideia de experimentação desempenha no segmento de consumo gourmet. Vimos que o treinamento de barista, depois de passar por uma etapa mais mecânica e operativa, é basicamente voltado para o entendimento dessa plasticidade sensitiva, isto é, a fragilidade de toda conjunção entre a percepção e o objeto percebido. Nesse momento, reina uma atmosfera de incerteza. Todas as preferências são suspensas. Os hábitos precisam ser re-instalados, dessa vez numa era em que a multiplicidade de opções é o ponto de partida. É possível dizer que o modo de apreensão dos objetos adquirido nesse momento se estenda para o resto da vida de um barista. Trata-se daquilo que chamamos de disposição estética-gustativa: a capacidade de apreender as características dos produtos através da comparação sucessiva. Os autores Teil e Hennion (2004) chegam a falar da criação de uma "incerteza criativa":

A questão aqui não é sobre como o chamado corpo natural é de fato determinado, domado, performatizado e deformado pelo nosso ambiente social. Ainda mais importante, a questão é sobre a co-produção de um corpo desejante e de um objeto desejado através de uma atividade coletiva e altamente equipada. Nenhuma língua, nenhum gosto pelo vinho, nenhum nariz existe sem o processo mesmo da degustação de vinhos; nenhum ouvido musical existe sem a música para ouvir. O corpo - ou, mais precisamente, o nosso equipamento "corpo e alma" - (assim como os objetos, os coletivos e os dispositivos de gosto), é um resultado que emerge da atividade de degustação [tasting] (Teil 1998), e não uma dada realidade, e nem um corpo físico autônomo e pré-existente apenas precisando da formação musical ou gourmet. (...) Nossos corpos e almas, assim como as obras musicais e as técnicas, o sabor dos vinhos ou as nossas identidades de amadores [amateur], não são nada além de meios e produtos de uma contínua performance, sempre hesitante e incerta. O gosto é exatamente a habilidade de gerenciar essa incerteza criativa: não se trata de gostar de algo que já sabemos, mas da alteração da nossa capacidade de gostar mediante o contato com uma coisa nova; na maioria das vezes essa coisa é pré-apresentada por outros amadores que atuam como mediadores das nossas próprias

123 "A systematic and critical review of the most prominent research on the subject has revealed that when it comes to the status of products concerned with taste, the various disciplines are divided, unsatisfactorily, along the lines of a nature-culture approach: either food products are just things and their properties are analysed through laboratory tests and measurements; or they are simply signs, the media for various rites and mechanisms of social identity, in which case their physical reality disappears in the analysis. In our opinion, this duality is detrimental in so far as it eliminates the very object of taste, i.e. it obscures the inevitable uncertainty about the effects that arises, about the nature of attachments, on the variable importance of the product tasted, on the circumstances of the tasting and the taster, and, more generally, on the systematic heterogeneity of the elements involved in preferences and habits." 
preferências. (TEIL \& Hennion, 2004, pg. 32) ${ }^{124}$

Os autores Méadel e Rabeharisoa (2001) também abordam a questão da proliferação da degustação/experimentação no mercado de comida. A tese principal defendida por eles é a de que as sessões de degustação, sejam elas praticadas nas fábricas, no laboratório ou nos supermercados, resultam em julgamentos que funcionam como "pontos de referência" para o mercado mais amplo. Uma vez que o gosto (taste) é uma propriedade compartilhada pelo produto e pelo degustador, o ajuste entre os dois polos, ou entre a oferta e a demanda, só se realiza de forma problemática e incerta. Como consequência, as referências coletivas se tornam imprescindíveis. O próprio consumidor é tido como um uma espécie de degustador menos equipado para a apreensão das propriedades dos objetos, mas igualmente interessado na avaliação dos mesmos. É cada vez mais palpável a ideia de um consumidor qualificado nesse aspecto, ou pelo menos no sentido de treinar melhor a percepção dos sabores básicos (doce, salgado, azedo e amargo). No caso do café, o contato com a figura do barista potencializa esse tipo de capacitação do corpo. $^{125}$ Quanto à questão da linguagem que usamos para nos referir às nossas preferências em relação aos produtos (para além das suas propriedades materiais), também essa linguagem possui uma história mais abrangente. Podemos conceber parte da história do conhecimento ligado às artes e ao sensível, nos últimos séculos, como uma história de codificação da linguagem abstrata do gosto, uma espécie de definição das formas de envolvimento subjetivo que podemos ter com as coisas. ${ }^{126}$ Isso porque, ao elegermos uma

124 "But the question here is not primarily about how a so-called natural body is in fact determined, tamed, performed and deformed by our social environment. Even more importantly, it is positively about the coproduction of a loving body and a loved object through a collective and equipped activity. No tongue, no taste for wine, no nose without the whole wine-tasting process; no musical ear without music to hear. The body — or, more accurately, our 'body and soul' equipment - is (like the objects, collectives and devices of taste) a result emerging from the activity of tasting (Teil 1998), and not a given reality, not an autonomous and pre-existing physical body just needing a musical or gourmet training. (...) Our bodies and souls, like musical works and techniques, like the taste of wines or like amateurs' identities, are nothing but the means and the products of an uncertain, tentative, ongoing performance. Taste is precisely about managing this creative uncertainty: it is not about liking something from what we already know, but about changing our ability to like from the contact with a new thing, most often pre-presented by other amateurs who serve as mediators of one's own taste."

125 Nós poderíamos denominar esse comportamento de capacidade formal de apreensão dos sabores, ou de discernimento sensório. Na linguagem de descrição organoléptica do café, os seguintes termos são recorrentes: corpo, aroma, acidez, amargor, doçura, adstringência, sabor residual e retrogosto. Todos os termos remetem para o aparato sensório-motor do consumidor.

126 Aqui a noção de gosto é tomada em seu sentido metafórico e não literal (gustibus), deixando de lado a vinculação com o paladar propriamente dito. 
preferência pessoal, sempre há o problema do caráter arbitrário desse julgamento ou da possibilidade de sua justificação diante de outras pessoas.

Steven Shapin, sociólogo da nova leva do Science and Technology Studies (STS) e que também se dedica a questões de ordem epistemológica, recentemente tem dirigido sua investigação para o problema do gosto tomando o caso dos apreciadores de vinho. Em artigo recente (2012), o sociólogo explicita o que está em jogo nessa guinada: entender como a subjetividade trabalha na produção do conhecimento, não mais enquanto aquilo que polui a objetividade. Desse modo, o gosto como modo de subjetivação aponta para a dimensão inconsciente da produção do conhecimento, essa dimensão altamente sensitiva e experimental. Esse tipo de subjetividade está diretamente vinculado ao problema da percepção, aisthesis: termo que significa "experiência sensorial" e que está na origem da palavra estética. É nesse contexto que Shapin resgata o problema kantiano da antinomia do gosto:

Na Crítica do Juízo, Kant definiu e discutiu o que ele chamou de "antinomia do gosto". Ele observou que existem dois princípios de julgamento, os dois igualmente válidos, mas cada qual parecendo dominar e excluir o outro. Por um lado, o gosto é uma resposta interna, privada, sentida - subjetivo no sentido em que não há nenhuma maneira de eu sentir o que você sente. Por outro lado, o gosto é algo que se pode dar razões, razões que podemos comunicar - objetivo no sentido de que tais razões existem e que nós possamos anexá-las ao objeto em questão. (SHAPIN, 2012, pg. 175) ${ }^{127}$

Teoricamente, nenhum filósofo depois de Kant conseguiu resolver o problema da antinomia do gosto: como produzir acordos mútuos sobre aquilo que diz respeito ao foro mais íntimo da subjetividade? Na prática, porém, essa questão tomou um rumo diferente, pois a "contradição" só aparecia aos olhos daqueles espíritos que não conseguiam misturar o doce e o salgado, por assim dizer. Foi a gastronomia moderna que forneceu os subsídios que faltava à epistême setecentista, dilacerada entre o universal e o particular. Os filósofos de então estavam preocupados em fundamentar um modo de fazer crítica dentro do domínio recém autonomizado da arte, mais propriamente as Belas Artes (pintura, música,

127 "Kant's Critique of Judgement named and discussed what he called the 'antinomy of taste'. There are, he observed, two principles of judgement, each of which is valid but each of which seems to rule out the other. On the one hand, taste is an internal, private, felt response - subjective in the sense that there is no way that I can feel just what you feel - and, on the other hand, taste is something we might be able to give reasons for, reasons which we might communicate - objective in the sense that such reasons exist and that we can attach them to the object in question." 
teatro, literatura). Junto com a figura do gênio artístico, a figura do crítico surgiu no período com o intuito de cumprir uma função social, a função de elo intermediário entre a percepção do público e a fabricação da obra de arte. Mas o impasse epistemológico sobre como fundamentar os critérios da boa arte permanecia em aberto. Porque a retórica do crítico de arte não podia ser calcada no conhecimento rigoroso, formalista, de inspiração matemática, pois assim a arte como um todo perderia o vínculo com o inefável, com o sublime, traço fundamental do seu caráter distintivo. Como a gastronomia estava em ascensão, enquanto corpo de conhecimento sobre a arte de bem comer, uma comunidade de leitores já havia se acostumado com a expressão "gosto" (gustibus, percepção gustativa, paladar, sapor, sabor dos alimentos) para se referir ao prazer dos sentidos diante de uma comida bem construída por um chef. Nesse momento se estabeleceu uma afinidade eletiva: os filósofos se apropriaram da noção gastronômica do "gosto" e estenderam a expressão à contemplação estética de uma forma em geral, isso porque a recepção estética envolvia um tipo de contemplação prazeirosa que não podia ser plenamente convertida em léxico racional, sua essência era intuitiva. E o gosto sempre foi intuitivo: evolutivamente ele teria sido adquirido pela espécie humana para distinguir o alimento próprio do venenoso, segundo o historiador da alimentação Jean-Louis Flandrin (1991). No entanto, os séculos XVI, XVII e XVIII, progressivamente, elevaram a cozinha a uma forma de arte e refinaram os modos de comer à mesa. O gosto foi "racionalizado", virou termo literário, modo de comunicação entre os homens: o que você gosta de comer? A partir daí ouvia-se e falava-se a linguagem do gosto. Foi um momento oportuno para aqueles que sentiam falta de um léxico adequado à fundamentação crítica e interna ao domínio das artes. Flandrin (1991) chama atenção para esse cruzamento, trata-se do surgimento quase simultâneo da noção de "bom gosto" no campo da alimentação e no domínio artístico e literário. A noção literal de "gosto" (paladar) aparece agora como metáfora de um discernimento pronto que antecede a reflexão; um juízo intuitivo e imediato com apreço pelo belo. Doravante, agora também em matéria de arte pode-se dizer: o que faz seu gosto? Da gastronomia rouba-se um termo para a validação do saber artístico em geral, o acordo tácito, o gosto compartilhado pelos amantes de uma mesma coisa. Nesse mesmo momento, a arte torna-se o alimento do espírito. E até hoje essa tendência não deixa de ter sua influência nos 
mecanismos de organização da produção e consumo de bens, como estetização geral da mercadoria. ${ }^{128}$

Em texto intitulado "A mudança dos gostos na era moderna", Shapin (2013) se engaja na interpretação de textos do começo da era moderna, entre os séculos XVI e XVIII, para entender a ruptura cognitiva estabelecida no século XIX em termos dos princípios gerais da classificação do gosto. O autor observa que, até o século XVIII, predominou uma visão que entrelaçava a análise das qualidades saudáveis do alimento à percepção de seu sabor (como demonstra o ditado bastante repetido Quod sapit nutrit, "aquilo que tem gosto bom é nutritivo"). Nesse tempo, os textos eram simultaneamente dietéticos e culinários, defendendo basicamente o preceito de que cada homem é seu próprio médico. Com o desenvolvimento de domínios especializados do conhecimento - a expertise do químico, a do médico fisiologista e o connoisseurship gastronômico do chefe de cozinha - essas coisas que andavam juntas, o gosto e a digestão, se separaram. ${ }^{129}$ Isso trouxe uma espécie de revolução científica para o campo da culinária: o vocabulário do gosto foi desontologizado, ou seja, perdeu a amarra epistemológica substancialista, unitária e foi problematizado, dividido em domínios de análise especializados. ${ }^{130}$ Desenvolveu-se um vocabulário químico (sal, ácido, óleo) que tentava explicar o alimento sem o apelo ao sabor e ao cheiro (que antes eram percebidos como guias confiáveis para a saúde). Enfim, houve uma grande mudança na configuração do conhecimento. Shapin argumenta que, dessa forma, a linguagem do gosto pode se desenvolver mais livremente como elemento de conversa entre os apreciadores da boa comida - que eram também os apreciadores da boa leitura e da boa arte em geral. Isso impulsionou a metáfora do gosto como juízo pré-

128 Sobre a noção de "estetização da mercadoria”, Cf. BOLZ, 1992.

129 Ambas as palavras expertise e connoisseurship possuem aqui o sentido do aporte de "conhecimento especializado". Optamos por deixar as expressões usadas por Shapin (2013).

130 Essa questão da autonomia da linguagem do gosto apareceu numa das respostas do questionário para baristas, na questão 10, perguntado sobre os "sabores" que a profissão barista ajuda a desenvolver o entrevistado respondeu Blue Berry, ou seja, o nome de um tipo específico de café aromatizado com essa fruta. O restante das respostas apenas acionou referentes abstratos da degustação: amargor, acidez, adstringência, corpo, etc. A ideia aqui é a de que existe uma linguagem abstrata do gosto que pode ser desenvolvida e operar menos atrelada às coisas concretas. Referentes concretos e referentes abstratos. 
reflexivo do belo. A fórmula se disseminou. ${ }^{131}$

Segundo Flandrin (1998a), o afastamento da função dietética e da função gastronômica, ou seja, do alimento como fonte de saúde e do alimento como fonte de prazer ocasionou a "autonomia gula": os consumidores não exigem aos cozinheiros mais do que contentar seu paladar e criar receitas que lhes surpreendam. Em termos de organização do hábito alimentar, a antiga medicina contava com a ideia da diversidade dos apetites humanos, isso em confluência com a teoria dos humores e dos temperamentos de caráter individual. Já a nova cozinha contava com a ideia de uma "harmonia dos sabores", pois ela levava o comer para além do necessário e do digestivo, ambos individualmente pensados. Nesse movimento, surge uma nova gramática do gosto, uma gramática da boa harmonia dos pratos, da delicadeza (délicatesse) do preparo e do gosto enfim como "bom gosto": adequação a uma nova norma de refinamento dos costumes. Para os nossos propósitos, essa passagem do historiador Flandrin é importantíssima:

Com efeito, na Idade Média e até no início do século XVII, a alimentação das elites seguia muito de perto as prescrições dos médicos, tanto no que dizia respeito à escolha dos alimentos como à maneira de cozê-los, temperálos e comê-los. (...) Nos séculos XVII e XVIII, com a desculpa de um gosto novo, todas essas precauções higiênicas tendem a desaparecer e todas as referências à antiga dietética se apagam. Cozinheiros e gastrônomos só sabem falar de harmonia dos sabores e esquecem, de resto, que os sabores eram até então ligados tanto a eles como aos médicos; sabiamente classificados do mais frio ao mais quente, eles constituíam uma indicação segura da natureza dos alimentos e de sua digestibilidade. Esses "antigos médicos" começam então a ser considerados defensores de uma ciência ultrapassada. Com efeito, os redatores do Dicionário de Trévaux, por exemplo, a partir de 1704, reportam-se a princípios químicos - aos ácidos, aos sais, ao tártaro, etc. - sempre que se trata de digestão. (...) Estaria o progresso da ciência na origem dessas transformações de gosto, que os gastrônomos da época entendem como um progresso da sensibilidade gastronômica e da arte culinária? É possível uma terceira leitura: esse afrouxamento dos laços entre cozinha e dietética liberava de alguma forma a gulodice; os refinamentos da cozinha não visam mais manter a boa saúde das pessoas, mas satisfazer o gosto dos glutões. Com uma pequena diferença: estes ainda não se reconhecem como tais e se apresentam como pessoas de

131 Shapin também tira essa ideia do historiador Flandrin, novamente: "Essa evolução significa que, para falar de aptidão para distinguir o belo e o feio nas obras de arte foi necessário recorrer a uma metáfora, e a única encontrada foi a do gosto alimentar. Isso indica, por um lado, um forte desenvolvimento do interesse pelas belas artes - música, pintura, escultura, arquitetura, poesia e literatura sob todas as suas formas - ao longo do século XVII. Esse interesse manifestou-se não só pela multiplicação das obras de arte, mas também pela ampla difusão do discurso crítico feito sob as mesmas e pela valorização das pessoas de bem que, segundo se presume, conhecem esse campo. Por outro lado, o fato de tomar por empréstimo esse termo sugere que as pessoas de bem estavam preocupadas com o gosto do que comiam e não se privavam de discutir a seu respeito.” (FLANDRIN, 1998a, pg. 684) 
paladar apurado, apreciadores de iguarias e peritos na arte de reconhecê-las. (...) O gosto, este sentido que a natureza dotou os homens e os animais para discernirem o comestível do não-comestível, sofreu, aliás, em meados do século XVII, uma estranha valorização: fala-se dele a partir daí em sentido figurado a propósito da literatura, escultura, pintura, música, mobiliário, vestuário, etc. Em todos esses domínios, é ele que permite distinguir o bom do ruim, o belo do feio; é o órgão característico do "homem de gosto", um dos avatares do homem perfeito. Ora, essa valorização implica uma certa tolerância para com os glutões. (FLANDRIN, 1998c, pg. 548-9)

É nesse sentido que se observa uma diminuição do preconceito contra a gula, um dos pecados capitais. Pois agora os gulosos, caso provenham de famílias da elite bem nascida, passam a ser tomados como apreciadores de gosto apurado e, em uma palavra, bon-vivants. Assim, o gosto compartilhado pelos apreciadores refinados - os friands, gourmands, gourmets, gastrônomos - ajudou a firmar costumes alimentares desprendidos da antiga dietética. Nesse movimento, a culinária apareceu como forma de arte. Na França da época, um exemplo do novos costumes alimentares era o ato de comer melão com pimenta e sal acompanhado de uma taça de vinho Marsala, uma verdadeira experiência simbolicamente marcada. Nesse compasso, estabeleceu-se uma espécie de objetividade do bom gosto, já que o julgamento não mais depende do humor dominante no consumidor tomado isoladamente. Assistimos, a partir daí, a operação de uma gramática normativa do gosto, definindo as prescrições quanto ao padrão apreciativo que convém seguir. Como o gosto clássico em geral, prevalecente entre os séculos XVII e XVIII, era ligado a uma concepção de arte vinculada ao belo natural, também em matéria de alimentação a preferência aos poucos foi se dando por temperos simples e gostos naturais, não necessariamente "saudáveis" à luz dos valores atuais. De temperos ácidos, fortes, carregados em especiarias passa-se a temperos gordurosos (manteiga) e açucarados; desenvolve-se o gosto por legumes, por frutas, lacticínios, manteiga, carne de açougue, doces; passa-se a cultivar mais hortas e pomares; há uma reabilitação dos alimentos locais; há um declínio considerável no consumo de pão e cereais; tudo isso em relação à Idade Média, nos países que hoje compõem a Europa (FLANDRIN, 1998c). Todas essas mudanças nos hábitos alimentares, apontadas por Flandrin, refletem a transformação que viam passando as elites europeias, um processo de centralização do poder e, portanto, de necessidade de complexificação das estratégias de marcação simbólica da ascensão social. 
Segundo Flandrin, esse movimento resulta em um paradoxo sociológico. Porque esse conjunto de novos costumes alimentares, junto com o surgimento de novos utensílios e das novas maneiras de comer à mesa, tais como o uso de garfo, copo, faca e colher individuais, descritos por Elias n'O Processo Civilizador, ou o surgimento da sala de jantar, dos novos horários de refeição das elites, e assim por diante, todas essas mudanças contribuíram para aumentar, por um tempo, a distância entre os diferentes meios sociais. No entanto, ao mesmo tempo, observou-se hierarquias mais suaves à mesa: "à mesa procura-se cada vez mais agir como se os convivas fossem iguais" (FLANDRIN, 1998c). De agora em diante, a igualdade à mesa tem como contrapartida a exclusão daqueles que possuem outra condição social. Nesse exato instante, surgem novos perigos: a possibilidade da cultura, da conversação e das maneiras de se comportar em público revelar uma pertença social inferior, à exemplo das maneiras reveladoras do povo e da pequena-burguesia. ${ }^{132}$ Não podemos esquecer que estamos falando de um mundo de competitividade acirrada pelo poder, o mundo da "sociedade de corte" como modelo de sociabilidade. Nesse sentido, há um real aumento do fosso social - ao mesmo tempo que uma suavização das estratégias de distinção, que são sempre estratégias de afastamento e aproximação entre os grupos.

O empenho de Norbert Elias n'O Processo Civilizador (2011) serve-nos de modelo no que se refere à descrição sociológica desses processos de longa-duração. Ao articular o tema da alimentação, o autor alemão enfatiza em seu trabalho a questão dos códigos de conduta, isto é, da exibição social das classes na esfera das despesas domésticas, agora tornada pública. Essa transposição ocorre mediante o monopólio de determinadas maneiras de se comportar à mesa. Para os nossos propósitos, interessam muito menos as maneiras de se portar do que o próprio regime alimentar dos grupos sociais, suas escolhas materiais. Elias procurava demonstrar como processos civilizadores se manifestam na definição

132 Alguns autores da chamada História da vida privada discordam da tese de que as regras de etiqueta da sociedade de corte foram aos poucos se internalizando nos estratos burgueses, como forma de exposição pública de si. Chartier, por exemplo, fala do desenvolvimento de uma certeza interna da estima burguesa, ligada cada vez mais aos gastos privados e à manipulação dos afazeres domésticos: "Os arranjos dos pequenos apartamentos, as decorações de interior, os móveis e as vestes concebidas para a intimidade doméstica, as atenções culinárias que discriminam produtos e cozimentos são sinais de uma nova maneira de viver que já não precisa da cena pública para marcar ostensivamente as distâncias sociais, mas pode satisfazer-se com uma certeza de superioridade vivida em privado, auto-atribuída" (CHARTIER, 1998, pg. 166). Retomar essa questão alhures. 
renovada de gostos em literatura e arte. A questão da formação social do gosto no seu sentido primeiro, como paladar, é colocada por Stephen Mennell (1987), enriquecendo o modelo analítico eliasiano, ao trazer à tona o componente propriamente gustativo da atividade alimentar. À luz dessas inspirações, procuramos investigar o surgimento do interesse mercantil pela justaposição da variedade de um mesmo produto nas prateleiras dos estabelecimentos de venda, sejam eles supermercados ou cafeterias. De extrema importância para os nossos interesses é a problemática da relação entre gosto e socialização pelo mercado. Nossas investigações giraram em torno da seguinte questão: como se dá a transmissão dos saberes relevantes à apreciação gourmet de um produto? Acreditamos que há sim mediações concretas, possivelmente até mesmo instituições que monopolizam os critérios legítimos de apreciação desses produtos. Ao nos perguntarmos quais são essas instituições estamos fazendo algo próximo de uma sociologia da expertise, na medida em que procuraremos mapear a formação do grupo mais amplo de apreciadores de café, grupo que, por sua vez, está distribuído numa gama de posições: baristas, degustadores profissionais, críticos gastronômicos e consumidores. Nosso foco nos baristas e nos consumidores envolve uma preocupação com o setor de serviços, na medida em que o advento de estabelecimentos voltados ao comer fora de casa, como é o caso das atuais cafeterias, precisa se coadunar com transformações que ocorrem também no âmbito da industrialização da comida, e não há melhor posição de visualizar essa conjunção entre produto-serviço do que mediante a análise dos protocolos da ocupação profissional destinada a servir o produto ao consumidor final. Aplicamos questionários em cafeterias da cidade de São Paulo e Brasília que, a nosso ver, pertenciam ao segmento de consumo gourmet. Interpelamos os baristas dessas cafeterias para descobrir as formas de aquisição de um padrão de gosto característico da nova fase de consumo de café. O desdobramento desse padrão de gosto, corporificado na figura do especialista barista e materializado nos tipos de produtos cuja ascensão foi abordada no capítulo anterior, será investigado no próximo capítulo. O contato, por vezes conflituoso, com o padrão de gosto tradicional do consumidor brasileiro constitui um caso interessante para se pensar as premissas metodológicas da sociologia do conhecimento e da sociologia do corpo.

Os questionários, em São Paulo, foram aplicados em sete estabelecimentos 
diferentes: Octávio Café, Il Barista, Por um Punhado de Dólares, Beluga Café, Urbe Café, Suplicy e Santo Grão. ${ }^{133}$ Já em Brasília, foram dez estabelecimentos: Bellini Coffee Experience, Café Cristina (202 sul e Iguatemi), Ernesto, Los Baristas, Grenat (315 norte e Iguatemi), Suplicy, Clandestino, Objeto Encontrado. ${ }^{134}$ Para um detalhamento maior sobre a forma e o conteúdo dos questionários, consultar Anexo ao final do capítulo. Agora teceremos apenas algumas observações que foram importantes para o desenvolvimento do argumento do presente capítulo, baseado no questionário que foi aplicado a 29 baristas. Uma primeira observação do resultado foi a de que a maioria dos estabelecimentos que eram redes já consolidadas (Suplicy, Santo Grão, Octávio) haviam treinado seus próprios funcionários para as tarefas de barista, enquanto que, nos estabelecimentos pesquisados de menor porte, os funcionários haviam recebido treinamento em outros lugares, como no Senac ou em cursos menores, a exemplo do Coffee Lab. Na pergunta 7 (Você já tinha contato com a degustação detalhada de comida e bebida antes?), 50\% dos baristas responderam "Não, foi o café que me levou a explorar esse lado", enquanto $36 \%$ responderam que já haviam tido contado com a degustação através de outros alimentos. Isso nos mostra o quanto a atuação e o curso de barista cumpre um papel socializador nesse sentido, na medida em que contribui para abrir o senso de degustação da bebida. Também nessa mesma direção, a pergunta 6 ( $O$ que você acha que trabalhar como barista ajuda a desenvolver?), teve 93\% de respostas em "Gosto/Degustação", contra 83\% e 88\% nas outras categorias de resposta. As três últimas perguntas foram formuladas para captar com maior precisão aquilo que foi desenvolvido sensorialmente pelos entrevistados, seja no curso de barista, seja no trabalho cotidiano da profissão. Descobrimos que os sabores mais associados ao café eram os seguintes (em ordem decrescente): doce, ácido, amargo, adstringente e azedo, conforme nos mostrou a questão 8. Vale lembrar que, embora na prática acidez e azedo constituam um mesmo sabor, 79\% dos entrevistados responderam "ácido" como uma característica associada ao café e apenas 17\% responderam "azedo", sendo que se tratava de uma questão de múltiplas respostas. Podemos explicar tal

\footnotetext{
${ }^{133}$ Os questionários foram feitos no aplicativo Survey Monkey, que é uma ferramenta de pesquisa online, e foram aplicados nas cafeterias via celular, entregando-se o celular para o entrevistado responder as questões in loco.

134 As razões das escolhas desses estabelecimentos foram enumeradas na nota de rodapé 70 (pg. 59).
} 
discrepância pela sutil necessidade de afirmação técnica, já que o termo "acidez" possui conotações mais sofisticadas do que o termo "azedo", geralmente associado a algo desagradável, como comer limão puro. A questão 9 (Você aprendeu a gostar de alguns desses sabores ao se envolver profissionalmente com o café?) nos mostrou que, sim, o trabalho como barista ajudou os envolvidos a desenvolverem a apreciação dos sabores numa determinada direção: $79 \%$ responderam "sim, trabalhar numa cafeteria me fez desenvolver o gosto por determinados sabores", contra 17\% que "já gostavam desses sabores antes". Na última pergunta, destinada a elencar os sabores adquiridos/ desenvolvidos no ofício de barista, nos chamou atenção uma das respostas que, ao invés de operar na abstração dos referentes comuns (acidez, amargor, etc.), acionou um tipo específico de café (blue berry), o que demonstra um pouco esse vai e vem entre o abstrato e o particular que faz parte do processo de desenvolvimento de uma aptidão prática intensiva em conhecimento, característica marcante no setor de serviços.

No debate sociológico, há uma oposição conceitual que se tornou bastante conhecida e que nos interessa de perto, a oposição entre o sistema fordista de produção e o sistema flexível contemporâneo (KON, 2007). Em resumo, o sistema fordista era mais rígido em termos organizacionais, dependia de uma integração vertical da firma capitalista, que era concebida como uma organização total. Já no sistema flexível, que se desenvolveu a partir dos anos 70, os serviços constituem o fator essencial, na medida em que as firmas precisaram lidar com economias de escala cada vez maior. As atividades não estratégicas e auxiliares passaram a ser externalizadas, ou seja, comandadas por outras firmas contratadas, processo que foi chamado de "terceirização". A partir de então, a produção em massa foi progressivamente sendo substituída pela complexa rede de serviços prestados uns aos outros e por uma maior complementaridade entre os bens e os serviços, já que todas as empresas passaram a investir bastante em processamento de informação/ conhecimento (por exemplo, as atividades de marketing, pesquisa \& desenvolvimento). Como resultado, houve uma maior diferenciação dos produtos finais (KON, 2007). Isso resultou na formação de uma "economia de nichos", em detrimento da economia de massa que focava na produção de bens industriais. Sobre essas mudanças do paradigma produtivo como um todo, Anita Kon diz o seguinte: 
A flexibilização dos processos produtivos e dos mercados trouxe ainda a necessidade do processamento de uma série de informações relacionadas ao aumento da complexidade dos ambientes externos e internos às empresas, bem como da competitividade nacional e internacional associada à agilização e constância da renovação dessas informações. (KON, 2007, pg. 132)

Nesse movimento, tornou-se imperativo uma sequência de rearranjos organizacionais que, em última instância, contribuíram para a formação de novos tipos de serviços e modalidades de consumo. O café gourmet é, em grande parte, resultado desse processo. A nosso ver, a intensificação do peso dos insumos de serviços na produção de bens materiais tem absoluta afinidade com o desenvolvimento histórico do "refinamento" e da complexificação dos esquemas de apreciação dos produtos. ${ }^{135}$ As definições mais gerais do conceito de "serviço" costumam apelar para três componentes fundamentais: ele é intangível (não possui palpabilidade material), é intensivo em informação-conhecimento e, nele, o ato de produção e o ato de consumo são simultâneos. Trata-se, em suma, da "prestação de um trabalho em uma cadeia de valor". No entanto, à medida que avança o setor de serviços, as fronteiras entre a parte material e a parte "intangível" da economia vão deixando de fazer sentido. ${ }^{136}$ Cada vez mais, a produção material das coisas e a produção via incorporação de conhecimento vão se tornando parte de um único e mesmo processo. Ora, entendemos que o conhecimento, seja na sua dimensão mais prática, como arte incorporada, habilidade e artesanato, seja como sistema de classificação científica e expertise teórica, cumpre um papel mediador das relações entre a produção e o consumo dos bens na economia de serviços. No caso do café gourmet, a conexão entre o polo da atividade de serviços, basicamente acoplada ao consumo, e o polo da atividade da indústria é explicitamente engendrada. Na prática diária do barista, a manipulação de esquemas de conhecimento teórico e o senso prático de preparo da bebida são aliados na composição da experiência oferecida ao consumidor: uma prestação de serviço que é, ao mesmo tempo, uma entrega de produto e uma "consultoria" sobre os diferentes esquemas de apreciação do

\footnotetext{
${ }^{135}$ Que podemos chamar de processo civilizador aplicado ao universo do consumo.

136 O termo "setor terciário", cunhado em 1935 por Fischer, apresenta o empecilho de ser tratado como uma categoria residual na economia como um todo. Nas metodologias de classificação e de contabilidade dos Estados e de órgãos internacionais como ONU, Banco Mundial e FMI, as atividades de serviços constituem "um saldo decorrente da diferença entre o montante do valor total agregado na economia e o montante agregado nas atividades de indústria e agricultura" (SILVA E MEIRELLES, 2006, pg. 127). Isso constitui um problema, aponta Dimária Silva e Meirelles, visto que sabemos que existe uma total interdependência entre essas duas formas de trabalho na economia.
} 
produto. $\mathrm{O}$ momento de contato entre o barista e o consumidor é, portanto, decisivo:

É dito tantas vezes no circuito dos cafés especiais que virou um truísmo: a qualidade só é criada no início da cadeia, nosso trabalho como indústria é preservar e aprimorar essa qualidade natural. Mas por mais que pareça verdadeiro, também é verdade que o valor é criado no final da cadeia, no exato momento em que o consumidor paga por seu café. E o quanto os consumidores dão valor a essa experiência afeta diretamente o quanto eles estão dispostos a pagar e, portanto, o quanto somos capazes de transmitir para trás da cadeia. E um acontecimento imenso, esse instante da interação do consumidor com o nosso produto. (GIULIANO, Peter. "Giving people what they want". The Specialty Coffee Chronicle, December 11 2014. $)^{137}$

Isso levou alguns autores a falar desse segmento através da ideia de "consumo de memórias e experiências" (TEXEIRA, 2014). Para Texeira, o ato de degustação de café, agora mediado pela figura do barista, que é um "conhecedor de diferentes grãos, moagens e torras", torna-se um "ritual social que ganha significado simbólico de maior sofisticação". Desse modo, ao serem progressivamente convertidos para a ritualização do consumo, os novos consumidores tornam-se cada vez mais atentos à complexidade sensorial a que pode chegar o café. Os autores Andreucci e Pompeu (2011) também argumentam na mesma direção ao analisarem as estratégias da marca Nespresso. Conforme esses autores, as ferramentas de marketing e comunicação da marca fazem parte da tendência contemporânea de substituição do consumo utilitário da bebida pelo "consumo ritualista", quer dizer, marcado por um conjunto de medidas que visam "transcender o valor diferencial intrínseco ao produto em direção a um valor experiencial” (pg. 616). Além disso, o valor experiencial teria diretamente a ver com a "estética da mercadoria": sua valorização simbólica em momento ulterior à produção propriamente dita, portanto, em detrimento dos "aspectos físicos, organolépticos e processuais do produto". ${ }^{138}$ A nosso ver, o movimento de "simbolização" do consumo não pode ser interpretado como restrito a uma espiritualização dos produtos do mercado, que agora passam a ser inscritos numa

137 "It's said so often in specialty coffee circles it's become a truism: quality is only created at the beginning of the chain, and our job as an industry is to preserve and enhance that natural quality. But as true as that might be, it is also true that value is created at the very end of the chain, at that moment when the consumer pays for their coffee. And how much they value that experience directly affects how much they are willing to pay, and therefore how much we are able to push back through the entire chain. It's an immense moment, that point of a consumer's interaction with our product."

138 À luz dessa perspectiva, a propaganda é definida pelo uso de "instrumentos pelos quais os significados são transferidos" (ANDREUCCI \& POMPEU, 2011). 
diversidade de "rituais". É inegável que a reorganização de mercado gourmet traz à tona novos símbolos e novos rituais de consumo. O seguinte enunciado resume a colocação: "Pense simbolicamente sobre o café que leva cinco segundos para ser feito e sai de uma torneira. Aí está. Versus o café como um processo que você começa a assistir e a participar e, em seguida, alguém serve essa coisa para você. Ele tende a ser mais bonito. E isso é uma grande transformação simbólica". ${ }^{139}$ Entretanto, isso não dá conta de toda a questão. Nós procuramos ver também a outra faceta do processo: em que medida novas materialidades são fabricadas e trazidas para perto de nós, em que medida novos arranjos socio-materiais são erigidos e novos sabores entram em circulação internacional, o que em conjunto reverbera enquanto remodelação do corpo consumidor típico. A disseminação do esquema da degustação é algo que ainda caminha seus primeiros passos. Todavia, a velocidade de crescimento desse fenômeno surpreende não apenas especialistas do mundo do café, mas é amplamente noticiada nas mais diversas reportagens de jornal e internet, em confluência com a ideia de gourmetização geral da sociedade.

139 "Just simbolically think about coffee like taking five seconds and going out of a tap. There it is. Versus coffee being a process that you get to watch and participate in and then somebody hands it to you. It tends to be more beautiful. And that's a huge symbolic change". A Film About Coffee. [filme] Direção: Brandon Loper. Avocados \& Coconuts, 2014. Red Epic, 67 min. 


\section{QUESTIONÁRIO PARA BARISTAS (29 RESPONDENTES)}

1. IDADE

Respondentes: 27 Ignoradas: 2

De 15 a 24 anos

De 25 a 34 anos

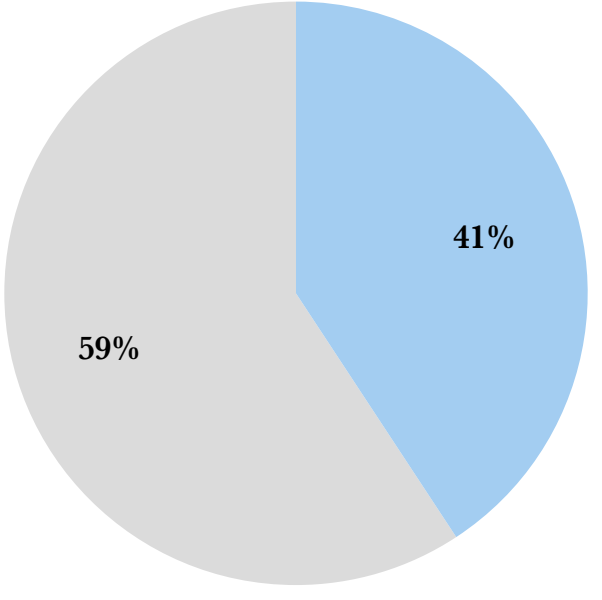

\begin{tabular}{|c|c|c|}
\hline De 15 a 24 anos & $40,74 \%$ & 11 respostas \\
\hline De 25 a 34 anos & $59,26 \%$ & 16 respostas \\
\hline $\begin{array}{c}\text { Acima de } 35 \\
\text { anos }\end{array}$ & $0 \%$ & 0 respostas \\
\hline
\end{tabular}

\section{VOCÊ SE CONSIDERA UM}

\section{BARISTA?}

Respondentes: 27 Ignoradas: 2

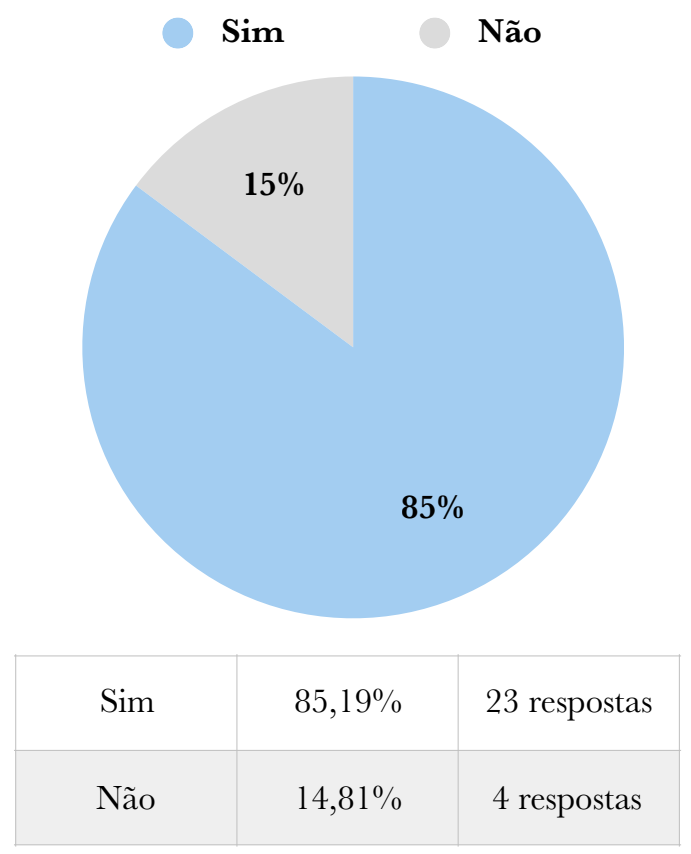

2. SEXO

Respondentes: 27 Ignoradas: 2

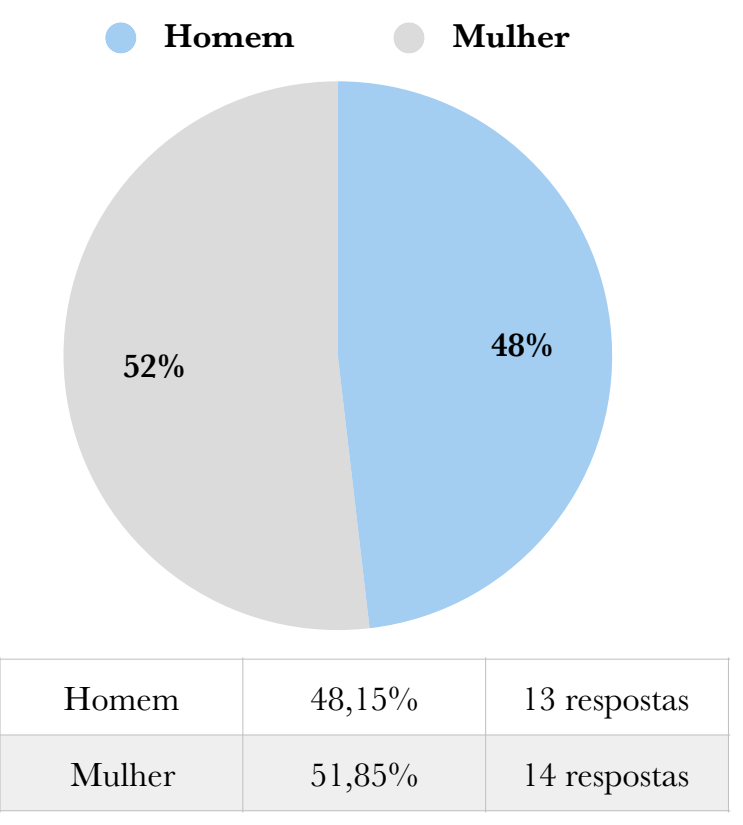

4. VOCÊ FEZ CURSO DE BARISTA? SE SIM, ONDE?

Respondentes: 23 Ignoradas:

\begin{tabular}{|c|c|}
\hline 1. No Suplicy & 13. Sim, Café Cristina \\
\hline 2. São Paulo & 14. Não fiz \\
\hline 3. Não & $\begin{array}{l}\text { 15. Santo grão oscar } \\
\text { freire }\end{array}$ \\
\hline 4. Não & 16. Suplicy Cafés \\
\hline 5. Não & 17. Suplicy Cafés \\
\hline 6. Sim, Clandestino & 18. Suplicy Cafés \\
\hline 7. Monardo Café & 19. Coffee Lab \\
\hline 8. Não fiz o curso & 20. Senac \\
\hline 9. Não & 21. Sim \\
\hline 10. Sim. SCAA & 22. Octavio \\
\hline 11. Coffee Lab & 23. Octavio \\
\hline 12. Café Cristina & \\
\hline
\end{tabular}




\section{COMO VOCÊ ENTROU EM}

\section{CONTATO COM O MUNDO DO}

\section{CAFÉ?}

Respondentes: 27 Ignoradas: 2

Eu já frequentava antes. Sempre gostei.

Era um emprego dentre outros que tentei. Precisava ganhar dinheiro.

Acho uma profissão super diferente, mas não costumava frequentar...

Outros

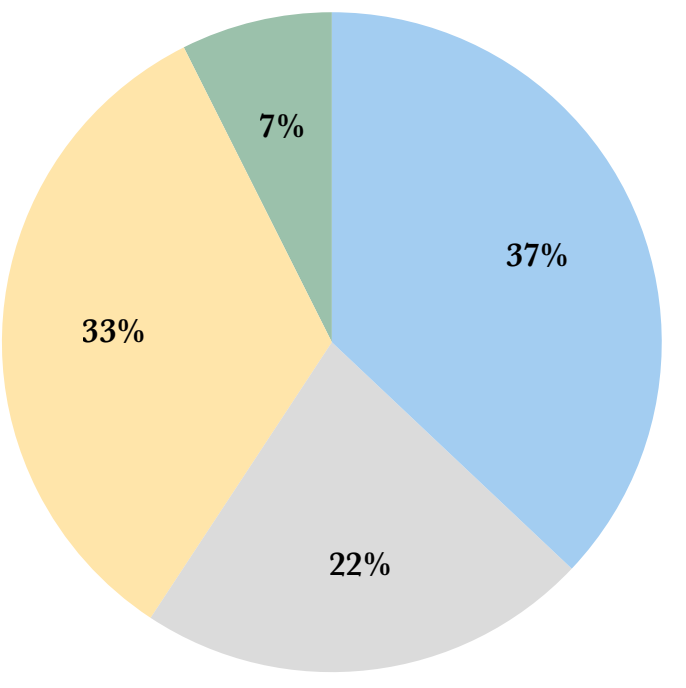

\begin{tabular}{|c|c|c|}
\hline $\begin{array}{c}\text { Eu já frequentava } \\
\text { antes. Sempre } \\
\text { gostei }\end{array}$ & $37,04 \%$ & 10 respostas \\
\hline $\begin{array}{c}\text { Era um emprego } \\
\text { dentre outros que } \\
\text { tentei. Precisava } \\
\text { ganhar dinheiro. }\end{array}$ & $22,22 \%$ & 6 respostas \\
\hline $\begin{array}{c}\text { Acho uma } \\
\text { profissão super } \\
\text { diferente, mas não } \\
\text { costumava } \\
\text { frequentar.. }\end{array}$ & $33,33 \%$ & 9 respostas \\
\hline $\begin{array}{c}\text { Outros } \\
\text { (especificar) }\end{array}$ & $7,41 \%$ & 2 respostas \\
\hline
\end{tabular}

\section{O QUE VOCÊ ACHA QUE}

\section{TRABALHAR COMO BARISTA}

\section{AJUDOU A DESENVOLVER?}

Respondentes: 29 Ignoradas: 0

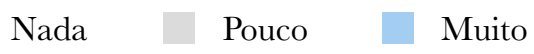






\section{VOCÊ JÁ TINHA CONTATO COM}

\section{A DEGUSTAÇÃO DE COMIDA OU}

\section{BEBIDA ANTES?}

Respondentes: 28 Ignoradas: 1

Não, foi o café que me levou a explorar esse lado.

Sim, já tinha contato antes. Por exemplo, através do vinho ou da cerveja.

Nunca tive contato.

Outros

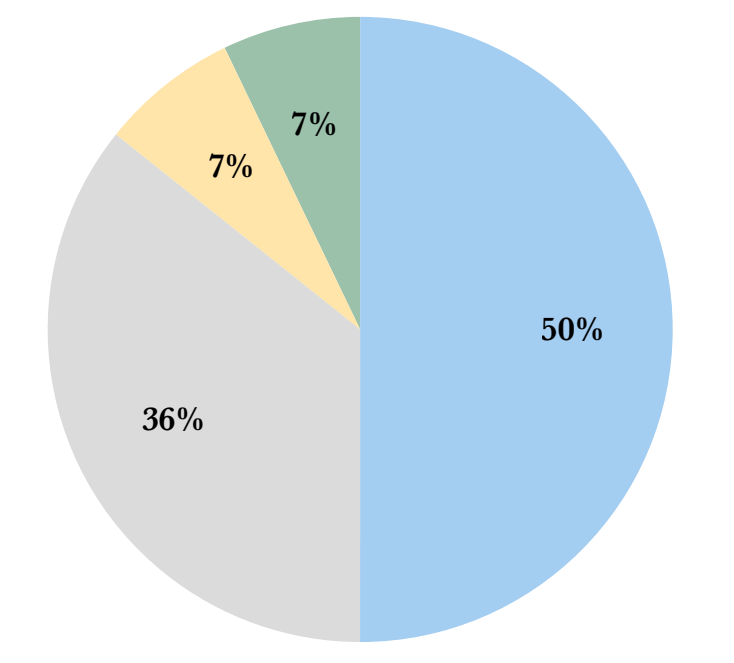

Não, foi o café que me levou a explorar esse lado.

\section{Sim, já tinha} contato antes. Por exemplo, através do vinho ou da cerveja.

\begin{tabular}{|c|c|c|}
\hline $\begin{array}{c}\text { Nunca tive } \\
\text { contato. }\end{array}$ & $7,14 \%$ & 2 respostas \\
\hline Outros & $7,14 \%$ & 2 respostas \\
\hline
\end{tabular}

\section{QUAIS CARACTERÍSTICAS DO} SABOR DO CAFÉ MAIS LHE

\section{CHAMAM ATENÇÃO?}

(Pode escolher mais de uma opção)

Respondentes: 29 Ignoradas: 0
Doce
Azedo
Ácido
Amargo
Não Sei
Umami
Adstringente




9. VOCÊ APRENDEU A GOSTAR DE

ALGUM DESSES SABORES AO SE

ENVOLVER PROFISSIONALMENTE

COM O CAFÉ?

Respondentes: 29 Ignoradas: 0

Sim, trabalhar numa cafeteria me fez desenvolver o gosto por determinados sabores.

Não, eu já gostava desses sabores antes.

Não gosto muito de alguns sabores que associo ao café, especialmente se for puro.

Outros



\begin{tabular}{|c|c|c|}
\hline $\begin{array}{c}\text { Sim, trabalhar } \\
\text { numa cafeteria } \\
\text { me fez } \\
\text { desenvolver o } \\
\text { gosto por } \\
\text { determinados } \\
\text { sabores. }\end{array}$ & $79,31 \%$ & 23 respostas \\
\hline $\begin{array}{c}\text { Não, eu já } \\
\text { gostava desses } \\
\text { sabores antes. }\end{array}$ & $17,24 \%$ & 5 respostas \\
\hline $\begin{array}{c}\text { Não gosto } \\
\text { muito de } \\
\text { alguns sabores } \\
\text { que associo ao } \\
\text { café, }\end{array}$ & $3,45 \%$ & 1 resposta \\
especialmente \\
se for puro.
\end{tabular}

10. SE VOCÊ RESPONDEU "SIM" NA QUESTÃO ANTERIOR, DIGITE O(S) SABOR(ES) QUE VOCÊ ACHA QUE O TRABALHO COMO BARISTA AJUDOU A DESENVOLVER?

Respondentes: 19 Ignoradas: 10

\begin{tabular}{|c|c|}
\hline $\begin{array}{l}\text { 1. Doçura, o ácido do } \\
\text { café! }\end{array}$ & $\begin{array}{l}\text { 11. Acidez do café } \\
\text { encanta, trabalhar como } \\
\text { barista é uma dádiva!!! }\end{array}$ \\
\hline 2. Acidez & $\begin{array}{l}\text { 12. Equilíbrio, tanino, } \\
\text { maracujá }\end{array}$ \\
\hline $\begin{array}{l}\text { 3. Gosto de velho e } \\
\text { adstringência }\end{array}$ & $\begin{array}{l}\text { 13. Cítrico, amargor, } \\
\text { acidez e corpo }\end{array}$ \\
\hline 4. Acidez, doçura & $\begin{array}{l}\text { 14. Sabores e aromas } \\
\text { frutados, percepção, } \\
\text { sabores; onde a língua } \\
\text { pega mais acidez, } \\
\text { doçura, amargo }\end{array}$ \\
\hline $\begin{array}{l}\text { 5. Os sabores ácidos e } \\
\text { brilhantes que um café } \\
\text { pode proporcionar }\end{array}$ & $\begin{array}{l}\text { 15. Acidez, amargor, } \\
\text { adstringência }\end{array}$ \\
\hline $\begin{array}{l}\text { 6. 2SL, 785, Bourbon } \\
\text { Vermelho e Amarelo }\end{array}$ & $\begin{array}{l}\text { 16. Conhecer, entender } \\
\text { sobre sabores }\end{array}$ \\
\hline 7. Amargo, adstringente & $\begin{array}{l}\text { 17. Acidez, intenção do } \\
\text { café }\end{array}$ \\
\hline 8. Acidez & 18. Blue Barry \\
\hline $\begin{array}{l}\text { 9. O trabalho de barista } \\
\text { ajuda a desenvolver } \\
\text { tanto o sensorial, como } \\
\text { profissional, cortes, etc. }\end{array}$ & 19. Sensorial \\
\hline $\begin{array}{l}\text { 10. Doçura, acidez, } \\
\text { corpo, retrogosto }\end{array}$ & \\
\hline
\end{tabular}


Figura 14 - Curso no Coffee Lab com o barista Renato Gutierres
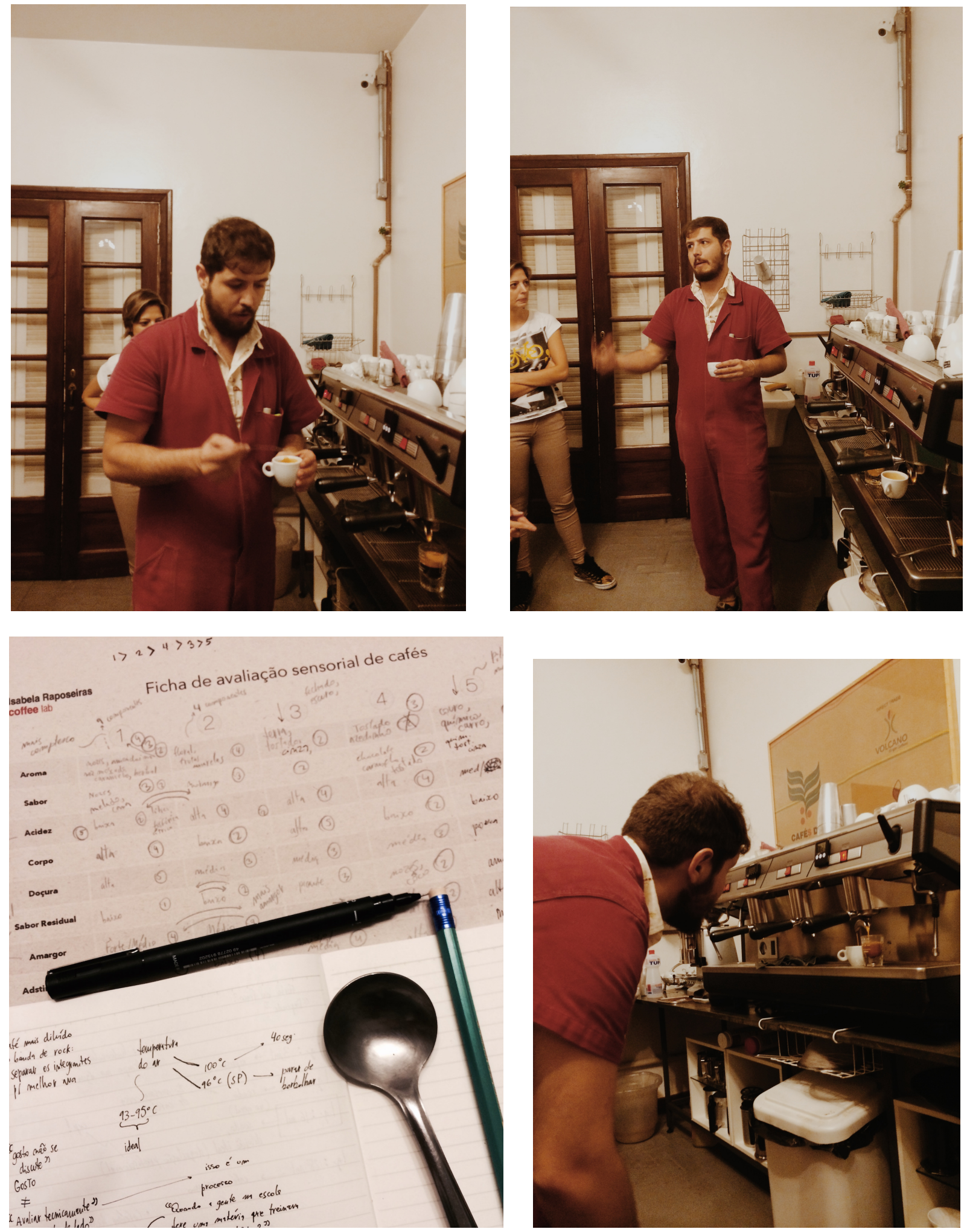

Fonte: fotografias elaboradas pelo autor 


\section{CAPÍTULO III \\ O CONSUMIDOR GOURMET EM CONFLITO}

Gourmet: 1. Conhecedor e apreciador de boa cozinha. É um termo francês consagrado e sem tradução adequada. Não confunda jamais um gourmet com um gourmand [aquele que só come o que é bom, porém em excesso; comilão], pois o fator requinte/know-how separa os dois, embora o amor à mesa os aproxime (Dicionário-Almanaque de Comes \& Bebes)

O mercado de cafés de alta qualidade vem crescendo rapidamente no país, como demonstra o consumo do café "gourmet", uma categoria da indústria para cafés de alta qualidade, que, desde 2004, cresce cerca de $15 \%$ ao ano, contra $3 \%$ dos cafés tradicionais. ${ }^{140}$ Certamente, esses dados expressam tendências no comportamento do consumidor brasileiro no que diz respeito ao consumo de café, mas não só. A nosso ver, é preciso levar em conta que essa tendência do mercado de café se coaduna com uma série de transformações que vêm ocorrendo no setor de indústria e de serviços no Brasil, na direção da maior valorização da experiência "refinada" de consumo. ${ }^{141}$ A proliferação de marcas com selos orgânicos ou bio, bem como de empresas que comercializam um leque variado de opções do mesmo produto, pode evidenciar um processo mais amplo de recomposição do mercado brasileiro. Nosso intento nesse capítulo é pesquisar em que medida esses novos usos sociais repercutem na criação de novas maneiras de se experimentar a desigualdade social. Com isso em vista, vamos começar o capítulo fazendo uma breve exposição da maneira pela qual o termo "gourmet" vem sendo tratado na imprensa em geral. ${ }^{142}$ Como veremos, a discussão costuma girar em torno do novo papel que a comida adquire nos dias atuais, como parte das estratégias de afirmação social por

${ }^{140}$ Edição Midiamax. "Mais saboroso, consumo de café gourmet cresce 5 vezes mais ao ano no país do que tradicional". Publicado em 24 jun. 2014. Disponível em: <http://www.midiamax.com.br/noticias/915697mais-saboroso-consumo-de-cafe-gourmet-cresce-5-vezes-mais-ao-ano-no-pais-do-que-tradicional.html $>$. Acesso: 24 ago. 2015.

141 Os adjetivos "refinado" e "sofisticado" estão entre aspas porque dizem respeito ao modo com que os agentes do mercado se autodenominam, portanto, não dizem respeito às crenças do autor acerca da superioridade dos produtos em questão.

142 Optamos por deixar a palavra "gourmet" entre aspas quando estivermos nos referindo ao discurso da imprensa sobre o processo de gourmetização. Manteremos a palavra em itálico quando estiver em jogo a maneira como entendemos tal processo do ponto de vista sociológico, conforme vínhamos fazendo nos capítulos anteriores. 
parte dos segmentos da sociedade brasileira. Quando o consumo se torna uma janela para o status, a própria situação de compra se transforma em um território de disputa, no qual diferentes estilos de vida se posicionam na hierarquia que envolve, acima de tudo, a "confiança de si" das diferentes classes. Em termos abstratos, partimos da premissa que a situação de compra no mercado é também uma situação de atualização das formas de simbolização humana e, nesse sentido, mudanças da ordem da organização mercadológica podem ter profundas implicações na forma de se conceber a sociedade como um todo. ${ }^{143}$ Voltaremos a essa questão mais adiante.

Talvez seja no comércio de alimentos que a tendência de refinamento dos costumes tenha se tornado mais radical. Para se ter uma ideia, o setor de alimentação, em 2013, cresceu numa razão três vezes maior que a do PIB nacional. ${ }^{144}$ Nos últimos anos, houve um surto de estabelecimentos que têm os nomes terminados em -aria ou -eria: brigaderia, tapiocaria, peixaria, leiteria, paneria, queijaria, gelateria, risoteria, hamburgueria, etc. $\mathrm{Na}$ reportagem "Sufixos à venda", o jornalista Edgard Murano chama essa nova onda de “explosão sufixal”. A derivação em si não é nova e significa um local especializado na venda ou na confecção daquilo que é apresentado como radical linguístico. No entanto, a proporção que a fórmula tomou não tem precedentes, podendo ser reflexo de uma nova gama de serviços disponíveis no mercado, aponta o jornalista. ${ }^{145} \mathrm{Na}$ esteira da gourmetização dos produtos, essas adaptações consistem em novas estratégias de marketing, ou, como diz Murano, uma "fórmula linguística-mercadológica" na qual o radical responde pelo produto e o sufixo (-aria ou -eria) pelo sentido de especialização. A onda dos sufixos não atingiu diretamente o universo dos cafés, pois a palavra "cafeteria" sempre foi empregada para se referir aos estabelecimentos especializados em café. Todavia, como fenômeno social mais amplo, a onda dos sufixos serve para nos situar diante das reconfigurações que vêm tomando o setor de serviços, como apontado no

143 Sociedade é entendida aqui como o conjunto das formas de associação e de aproximação entre seres humanos. Implica sim, portanto, a autodefinição humana como uma espécie animal à parte, destacável das demais pela complexidade interna de sua coordenação, na qual apenas membros de uma mesma espécie podem visualizar.

144 MURANO, Edgard. "Sufixos à venda". Revista Língua, Outubro, 2014.

145 Segundo o autor, embora a derivação seja um mecanismo natural de formação de palavras, "alguns casos de derivação acabam soando paradoxais ou forçados, e extrapolam o sentido da especialidade que carrega o sufixo tradicionalmente, até então restrito aos radicais de sua expertise (leite/leiteria, café/cafeteria, tabaco/tabacaria, etc.” (MURANO, 2014). 
parágrafo anterior. Em contexto de extrema competitividade, o "vocabulário gourmet" como um todo, que inclui a explosão dos sufixos, vem para atender a ânsia por diferenciação, que se expressa também na valorização da comida artesanal. ${ }^{146}$ Algumas vezes, o próprio termo "gourmet" é visto como um engodo, como algo que aparece apenas para dar uma nova roupagem a serviços tradicionais. Nas redes sociais, o termo se tornou objeto de piada, como demonstra a página virtual de humor chamada Raio Gourmetizador, que, em cada postagem, satiriza um produto específico. Na vez do café, a postagem tomou a seguinte forma: primeiro, há a imagem de uma xícara onde aparece escrito "Cafézinho: 2 real"; depois, há a imagem de um homem emitindo raio pelos dedos em direção à xícara e onde se lê a legenda "Raio Gourmetizador"; por fim, temos a imagem da mesma xícara de café, dessa vez com a legenda "Café 100\% Arábica, da Alta Mogiana, colhida nas primeiras horas do dia. Aromatizado em favas de baunilha. Acompanha pastilha de menta e água com gás: 15 real”. Ao focar no princípio da multiplicação dos preços, a página de humor do facebook soube capitalizar como nenhuma outra uma perspectiva pejorativa em relação ao "gourmet". Esse padrão se repete em algumas outras páginas da rede, como na "Gastronomia da depressão", na "Gastronomia da deprê" e até no canal de humor Porta dos Fundos. Na reportagem da revista Vida Simples intitulada "A moda gourmet", o termo aparece associado ao contingente de consumidores brasileiros que ascenderam socialmente na última década, entre 2000 e 2010. Conforme a Secretaria de Assuntos Estratégicos (SAE) do governo federal, houve uma considerável mobilidade social no período: de 2004 a 2010, 32 milhões de pessoas ascenderam à classe média (A, B e C) e 19,3 milhões saíram da pobreza, com um forte apelo ao consumo (MURANO, 2014). Tendo isso em vista, a questão acerca do novo perfil socioeconômico da sociedade precisaria ser levada em conta na discussão sobre a gourmetização:

Essa busca por "tendências no prato" também é um reflexo do momento pelo qual passa a gastronomia por aqui. $O$ poder aquisitivo aumentou a possibilidade das pessoas comerem fora - um crescimento de mais de $12 \%$ em 2013, segundo a Associação Brasileira de Bares e Restaurantes (Abrasel) —, programas culinários pululam nas grades da televisão, livros de receitas

146 Os autores Johnston \& Baumann (2015) definem a comida artesanal da seguinte forma: "uma combinação de ênfase na qualidade e na singularidade de cada ingrediente, artesania tradicional e habilidade artística, o lugar onde os produtos são feitos ou cultivados, e a paixão e personalidade do produtor", pg. 27. 
lotam as livrarias e, nas redes sociais, como o Instagram, proliferaram o hábito de compartilhar pratos.

Há mais dinheiro, existe um maior interesse por comida diferenciada, novos negócios na área surgem todos os dias, mas ainda falta informação, uma base cultural sobre a própria alimentação. E o resultado disso é que muita gente se tornou refém da gourmetização turbinada pelo consumismo. (...)

O "gourmet", que antes era uma forma de convencer clientes incautos a pagar algumas cifras a mais por uma simples coxinha ou um brigadeiro, já tem virado motivo de deboche nas redes sociais. (...) A questão está no esforço para dar uma nova cara a coisas que já existem. (TONON, Rafael. "A moda gourmet", Vida Simples, Fevereiro, 2015)

Em reportagens similares, o "gourmet" é visto como uma moda passageira das novas classes que não possuem capital cultural suficiente para discernir aquilo que possui qualidade daquilo que não possui. "Ascensão financeira, não acompanhada de educação", diz a professora de marketing da ESPM Daniela Khauaja, mais adiante na mesma reportagem citada. Dessa feita, a suposição de que o alimento de qualidade deve ser composto por ingredientes sofisticados, exóticos ou de origem controlada perde aceitação imediata entre os segmentos mais abastados do espaço social, aqueles que procuram se afastar das estratégias mais explícitas de afirmação social dos "novos ricos". Desconfia-se dos rótulos, isso no mesmo momento em que os rótulos e os nomes começam a se proliferar enquanto adicionais simbólicos do produto, tornando o luxo acessível para a chamada "nova classe média do período Lula". Diz-se também que a nova classe média é ávida por símbolos de distinção social e que o "gourmet" seria um desses símbolos, um mero "truque" de mercado que conquistaria consumidores desinformados. Explicita-se o mecanismo por trás: por um passe de mágica, toda uma gama de produtos é convertida numa versão especial e, pela lógica do raio gourmetizador, triplica de preço. Entre os arautos da consciência, os termos críticos se intercalam: é fetiche, engodo, glamour ou pura alienação. Conhecemos bem a narrativa. O mercado é tomado como vilão da história e a classe média indefesa, descapitalizada culturalmente, como a enganada. No entanto, algumas vozes procuram se desvencilhar dessa dicotomia que coloca os símbolos do mercado, em um extremo, e os defensores da consciência, em outro. Para alguns intérpretes, não se trata apenas de ilusionismo ("a qualidade é fabricada pelo discurso"), mas de uma verdadeira reconfiguração dos padrões de escolha dos produtos:

Para a antropóloga Livia Barbosa, tal fenômeno se liga a um contexto maior, 
de acentuação da dimensão simbólica do consumo onde ganha espaço, por exemplo, a valorização da origem dos ingredientes. Ao relacionar o produto a padrões superiores de experiência sensorial, a especificidade ganha espaço na experiência: saber como e onde o produto é feito faz cada vez mais parte do prazer em consumir. "É o chá de pétalas de rosa do Himalaia ou a calça tingida com pedras vulcânicas da Indonésia", ironiza. O mesmo vale para a retomada do rústico, do artesanal, do nativo, esse "falso simples" notório no boom recente da gastronomia de boteco e da roça, com produtos enaltecidos por valores como tradição e terroir. (VIEIRA, Willian."É o rótulo, estúpido!”. Carta Capital, 03 ago. 2014)

Nesse sentido, torna-se difícil tratar a gourmetização como apenas uma "modinha" do meio gastronômico, na medida em que o fenômeno passa a ser interpretado à luz das transformações mais duradouras que atingem a indústria, a agricultura e os serviços como um todo. ${ }^{147} \mathrm{~A}$ bem verdade, as transformações dizem respeito à integração de novos valores no mercado, a exemplo do apreço pela autenticidade dos produtos, uma autenticidade que, segundo se diz, seria perceptível na experiência sensorial dos produtos. Uma coisa é usar a terminologia "gourmet" para agregar valor ao produto depois que ele já está pronto, "resolver de forma cosmética o que deveria ser um ganho real", diz Livia Barbosa (VIEIRA, 2014). Já outra coisa é a progressiva internalização do gourmet no processo de produção e consumo do produto, pelo uso de ingredientes mais sofisticados, pelo uso de técnicas de manipulação menos agressivas e pelo uso de estratégias de apreciação mais pacientes. Entre esses dois extremos de postura, há todo um gradiente de variações mercantis. Mesmo assim, é possível atestar que grande parte da opinião pública permanece cética quanto ao uso do termo. A consultora Karyna Muniz afirma, por exemplo: "O gourmet remete à alta cozinha, a processos artesanais e experiências gastronômicas autênticas. Hoje, o termo está sendo usado como sinônimo de inovação e há uma banalização". ${ }^{148}$ Essa desconfiança se expressa também como uma tendência. Em uma reportagem da seção Paladar do Estadão, que saiu no dia 30 de Dezembro de 2014,

${ }^{147} \mathrm{Na}$ imprensa, as avaliações do uso do termo são múltiplas. Há a clássica postura cínica: "se tudo é gourmet, nada é gourmet" (ORENSTEIN, José. "\#gourmet". Estadão, 29 ago. 2013). Nesse mesmo sentido: "Resta saber se o modismo da glamourização dos alimentos vai resistir ao tempo. Provavelmente não" (TONON, Rafael. "A moda gourmet", Vida Simples, Fevereiro, 2015). Em outra reportagem, lê-se: "quem tem quase o monte de anos que tenho (56), há de se lembrar que houve um tempo em que a palavra executivo estava tão em voga quanto a de hoje, gourmet" (ALEMÃO, Marcio. "Gourmetizou, dançou". Carta Capital, 19 jul. 2014). Como contraponto, há as posturas mais conciliativas e menos acusatórias, tal como a citada acima.

148 KOPSCHITZ, Isabel \& OLIVEIRA, FILIPE. "Produtos gourmet chegam até a comida de cachorro, mas podem desaparecer mais rápido". Folha de São Paulo, 27 jul. 2014. 
perguntou-se a vários especialistas da gastronomia quais são as manias que podem ficar em 2014. Vários deles fizeram referência à banalização do termo "gourmet", que acreditam não ter razão suficiente para sobreviver em 2015. Dentre as respostas, as menções ao "gourmet" foram as seguintes:

"O uso dos termos gourmet e natural", Roberto Smeraldi, gastrônomo e diretor da Oscip Amigos da Terra - Amazônia Brasileira

"A palavra gourmet. Não precisamos mais dela. Seu uso não qualifica nem define", Isabela Raposeira, barista do Coffee Lab

"A banalização dos termos gourmet e artesanal", Patricia Ferraz, editora do Paladar

"Qualquer termo ligado à cozinha composto com estes: gourmet, fino/a, chique. Acho muito presunçoso", Neide Rigo, colunista do Paladar

"A banalização de termos como iguaria, criação, degustação (deixa pra usar só quando realmente valer)", Luiz Américo Camargo, crítico de restaurante do Paladar (Redação Estadão. "50 coisas que podem ficar em 2014". Estadão, Paladar, 30 dez. 2014)

Além das apreciações críticas ao termo, houve uma defesa do termo, que apelou para o processo mais amplo em direção ao conhecimento refinado dos produtos:

"A estigmatização do termo gourmet. Se existe gente que usa o rótulo gourmet para vender produtos vagabundos e caros? Lógico! Mas bobo é aquele que rechaça o que profissionais da área de gastronomia preservam a duras penas. Como identificar o que é falso e o que é original? Sendo um gourmet!", Rene Aduan, sommelier de cerveja e dono da Alma Rústica (Redação Estadão. "50 coisas que podem ficar em 2014". Estadão, Paladar, 30 dez. 2014)

Nos comentários da reportagem citada em versão online, a maior parte dos internautas endossou a crítica aos termos culinários que apontavam para uma glamourização excessiva dos alimentos. ${ }^{149}$ Assim como em outros campos, a questão aqui apareceu, de um lado, sob o prisma de uma intenção mercadológica perversa e, de outro, sob os diferentes modos de consumo contrários à roupagem esnobe do mercado segmentado, que vão desde o simples deleite até a conscientização política das escolhas

149 Doravante, um dos comentários se destacou por defender uma perspectiva radicalmente oposta aos outros, uma espécie de elogio ao refinamento dos costumes: "Muitos comentários parecem de novos ricos, aquele sujeito que vai pra Europa, pede um vinho muito caro e não entende porque o maitre segue um determinado ritual para servi-lo. Acha que é frescura, faz comentários irônicos em voz alta, quando na verdade é uma técnica necessária à degustação. Negar o clássico sob o argumento de que ele tem de sumir por estar sendo mal usado é o mesmo que demolir o Coliseu afirmando que ele é uma inspiração ao fascismo. Pura imbecilidade. Que o paladar brasileiro se sofistique cada vez mais. Que tenhamos cada vez mais gourmets, cada vez mais degustadores e cada vez mais críticos ao que é de fato ruim, incluindo o comportamento dos ignorantes que confundem educação e refinamento com patrulha." 
alimentares. Por mais que concordemos com a crítica ao uso manipulativo do vocabulário "gourmet" pelo mercado, não podemos fazer vista grossa para a importância que adquiriu a ritualização do ato de comer no mundo contemporâneo, agora elevado ao status de prazer gastronômico e permeado por nuances estilísticas (tanto as substâncias como seus adornos) que são invisibilizadas quando se toma a gourmetização apenas pelo prisma do marketing ou do interesse mercantil predatório. Isso não é tudo. Para os autores Johnston e Baumann (2015), ao falarmos das práticas alimentares contemporâneas não podemos nos reter apenas à cesta de comida de cada indivíduo ou aos restaurantes que ele frequenta, pois existe um amplo domínio discursivo por trás das estratégias individuais, isto é, um sistema complexo que qualifica toda "fala sobre comida" (food talk) e que hoje acompanha e se sobrepõe ao ato de comer propriamente dito. A questão, para os autores citados, é perceber como a comida é "enquadrada" (framed) através de práticas discursivas, em especial aquelas produzidas textualmente, mas não só. Dessa feita, o discurso culinário (foodie discourse) é tomado como prerrogativa de um conjunto de especialistas que operam em várias frentes do mercado: programas de televisão, revistas de culinária, websites, livros de receita, biografias de chefs consagrados, blogs, etc. No argumento dos autores, isso implica também na formação de um novo tipo de consumidor, os foodies, que são essas pessoas obcecadas por comida, cuja principal preocupação diz respeito ao sabor (taste) dos alimentos e que participam desse discurso de alguma maneira como consumidores do conhecimento especializado. Por carregar conotações de esnobismo, a palavra "gourmet" é evitada por grande parte desses consumidores que valorizam, ao mesmo tempo, a comida das pessoas comuns (classe trabalhadora, minorias étnicas, hole-in-the-wall) e a comida mais rara, economicamente inacessível, que pressupõe montantes significativos de capital cultural para ser apreciada. $\mathrm{Na}$ maioria das vezes, eles procuram se distanciar das demonstrações mais explícitas de esnobismo e de maior formalidade no trato da comida, representadas pela tradição culinária francesa. $\mathrm{O}$ aspecto estético do gosto é trazido à tona, a própria comida passa a fazer parte do conjunto de objetos culturais que revelam muito sobre a identidade e o estilo de vida daqueles que os consomem. Podemos conectar essas transformações no campo gastronômico com a disseminação daquilo que Pierre Bourdieu chamou de disposição estética: 
Para colocar de outra forma, o que parece ter importância no discurso foodie (para ambos os que aceitam e os que rejeitam o termo) não é necessariamente a lista dos alimentos que uma pessoa consome ou os restaurantes em que frequenta, mas a disposição que se dirige à comida como um objeto de estudo, de apreciação estética e de aquisição de conhecimento. Isso é fundamental, porque se relaciona com uma importante observação dos teóricos culturais de que os padrões de status e de distinção são criados e reproduzidos não apenas pelo conteúdo dos produtos culturais, mas pela maneira em que eles são consumidos. (...) Bourdieu (1984: 54) designou essa postura de "disposição estética", que diz respeito à atitude de se aproximar dos objetos do cotidiano, tais como a comida, de uma forma que deixa de enfatizar sua utilidade funcional (ex: o alimento como o combustível necessário para sustentar a vida) e, em vez disso, vê os objetos do cotidiano através da lente estética que prima pela valorização cultural e pela aquisição de conhecimento (ex: o alimento como um hobby sério, ou a refeição concebida como uma obra de arte). (JOHNSTON \& BAUMANN, 2015, pg. 51-52) ${ }^{150}$

Assim como a música e a literatura, o consumo de comida passa a ser associado ao quanto nos sentimos sofisticados, inteligentes, refinados e aventureiros, e como conseguimos demonstrar essa "confiança de si" para as outras pessoas. ${ }^{151}$ Há quem chame atenção para o fato de que, na cultura jovem, a comida substituiu o lugar ocupado pela música e, mais especificamente, pelo rock n' roll. O crítico gastronômico do Los Angeles Times, Jonathan Gold, foi um dos primeiros a explicitar tal conexão. Sua tese é de que o ato de comer está se tornando cada vez mais político, no momento em que a música tende a se despolitizar. ${ }^{152}$ Um outro escritor de comida, Zach Brooks, chegou a criar um podcast ${ }^{153}$ chamado Food is the new rock, um programa que entrevista músicos para falar sobre comida e pessoas do universo gastronômico para falar sobre música. No episódio em que

150 "To put it somewhat differently, what seems to matter in foodie discourse (for both those who accept and those who reject the term) is not necessarily the precise list of food that one consumes or the restaurants one dines at, but the disposition one brings to food - as a subject for study, aesthetic appreciation, and knowledge acquisition. This is significant, because it relates to an important observation by cultural theorists that patterns of status and distinction are created and reproduced not simply by the content of cultural products, but the manner in which one consumes culture. (...) Bourdieu (1984: 54) described this as an 'aesthetic disposition', which referred to the attitude of approaching everyday objects, like food, in a way that de-emphasizes functional utility (e.g. food as the fuel needed to sustain life), and instead views everyday objects through an aesthetic lens of cultural appreciation and knowledge acquisition (e.g. seeing food as a serious hobby, or conceptualizing a meal as a work of art)."

151 JOHNSTON \& BAUMANN, 2015, pg. 82.

152 Vale dizer que o "político" é entendido, para Jonathan Gold, no sentido de que o que uma pessoa come diz muito sobre sua visão de mundo, por exemplo, se ela apoia agricultura sustentável ou se ela consome organismos geneticamente modificados (OGM).

153 Podcasts são arquivos de áudio transmitidos via internet. Nesses arquivos, os internautas oferecem seleções de músicas ou falam sobre os mais variados assuntos, exatamente como acontece em blogs e em programas de rádio. A palavra surgiu da fusão dos termos iPod (tocador de MP3) e broadcast (transmissão via rádio). 
ele entrevista o chef dinamarquês René Redzepi, Zach define o conceito que está por trás do projeto:

\begin{abstract}
A música costumava ser muito mais política do que é agora. Costumava haver um monte de declarações [statements] por trás, isto é, o tipo de música que você gosta diz algo sobre você, sobre o que você acredita, sua visão do mundo. Eu acho que a nova música não faz mais isso do modo em que costumava fazer. Mas eu acho que os restaurantes fazem isso agora, muito mais que há 20 anos atrás... O Noma é um exemplo perfeito disso, toda a sua atitude em relação ao ato de cozinhar, de fabricar, os ingredientes que você utiliza... ele faz uma declaração [statement] muito específica sobre como você quer viver e fazer parte desse mundo. $\mathrm{E}$ eu acho que as pessoas que se sentem assim, isso ressoa nelas da mesma maneira que quando se ouvia Hendrix ou Janis Joplin. (Podcast. "René Redzepi". Food is the new rock, Zach Brooks, Ep. 74, December 17, 2013) $)^{154}$
\end{abstract}

Contidos os ânimos da constatação "food is the new music", nós corroboramos o argumento levantado. Em período de dificuldade experimentada pelas gravadoras musicais, cresce o papel que a comida e o universo gastronômico desempenham na criação de novas identidades culturais. ${ }^{155} \mathrm{Na}$ virada para o século XXI, a comida se transformou em um segmento de expressão cultural com ampla visibilidade, daí a noção de que a comida seria a "nova música". É comum, nos dias de hoje, as pessoas publicarem fotos de suas comidas nas redes sociais, momentos antes de arriscarem a primeira mordida. A nosso ver, esse tipo de atitude revela a magnitude que a comida adquiriu como parte de sua inserção na cultura pop como um todo. É importante ressaltar que uma série de fatores contribuíram para a consolidação dessa tônica, dentre eles: a ascensão do turismo culinário, impulsionado pelo interesse crescente por cozinhas globais; o apelo pelo local, orgânico e sustentável como parte do consumo eticamente orientado; a popularidade dos produtos e ingredientes gourmets / especiais; o sucesso dos programas de televisão culinários, ancorados na

154 "Music used to be way more political that it is now. There used to be a lot of statements behind, you know, what kind of music you like says something about you, what you believe in, your world view. I think new music doesn't do that nearly as much as music used to. But I think restaurants do now, far more then they did 20 years ago... Noma is a perfect exemple, your whole attitude towards cooking, forging, the ingredients you use... it makes a very specific statement about how you wanna live and be a part of this world. And I think people that feel the same way, that resonate with them the same way that listening to hendrix or janis joplin."

155 Diversas fontes apontam para a estagnação do faturamento da indústria fonográfica a nível mundial. No Brasil, entre 2005 e 2009 a venda de CDs e DVDs caiu pela metade (PIZARRO, Mariana. "Estudo mostra como as gravadoras sobrevivem na era da internet". [internet] UnBCiência, 17 jun. 2011). Como contrapartida, cresceram os números de compartilhamento ilegal de música pela internet, bem como os serviços de streaming, como o Spotify e o próprio Youtube (VASCONCELOS, Mônica. "Streaming é a luz no fim do túnel para a indústria fonográfica mundial?”. [internet] BBC Brasil, 09 maio 2013). 
celebridade dos chefs; a proliferação de discursos midiáticos sobre comida e o estabelecimento do jornalismo gastronômico como profissão (JOHNSTON \& BAUMANN, 2015, pg. 19). Enquanto alguns autores utilizam o termo foodies para se referir ao conjunto de pessoas que têm o prazer gastronômico como principal motivação, nós optamos pela palavra gourmet. Ela remete para além da questão dos “árbitros do bom gosto", na medida em que o fenômeno precisa ser entendido também à luz das transformações materiais dos produtos e dos ingredientes na indústria e na agricultura. Nesse movimento, assistimos a incorporação de uma série de parâmetros de qualidade do alimento e de valores culturais específicos (autenticidade, sabores, exotismo, diversidade étnica, sustentabilidade) que passam agora a andar juntos no processo de produção e consumo, ou seja, envolvendo não apenas os padrões de escolha, mas também a constituição material dos objetos que estão sendo consumidos. Trata-se do gosto no duplo sentido da palavra: gosto (no sentido metafórico) como disposição subjetiva aplicável a uma variedade de gêneros de objeto, e gosto (no sentido literal) como propriedade gustativa da coisa que se encontra diante do sujeito e com a qual ele precisa se conformar. Nos termos do processo de gourmetização, o prazer gastronômico propriamente dito entra em cena e, nesse movimento, a conformação dos objetos ao aparato sensório humano se multiplica, junto com a disseminação da cultura de degustação. No mesmo instante, a busca de um profile flavor (perfil de sabor uniforme) é abandonada pela indústria e a diversidade material e orgânica dos objetos é valorizada. O gourmet, à luz dessa reformulação conceitual, é um modo de percepção característico desse tipo de consumidor que valoriza a experiência multissensorial das coisas, coisas que, por sua vez, deixaram de ser padronizadas em relação a um ideal de sabor industrializado. ${ }^{156}$

A despeito de uma aparente orquestração orgânica, o processo não é isento de tensões e ambiguidades morais. Para adquirir uma relação mais estética com a comida é preciso, antes de tudo, tempo e dinheiro:

Ainda por cima, os alimentos autênticos podem ser bastante difíceis de serem

156 Enquanto aglutinação de tendências diversas, o modo de consumo gourmet estaria muito além da questão dos usos ou desusos do termo "gourmet". A gourmetização talvez seja um processo mais amplo e mais sutil do que o conjunto de vocábulos "gourmet" nos faz acreditar, esbarrando no limite daquilo que é possível trazer à consciência. Talvez seja algo próximo daquilo que os historiadores chamaram de "mentalidade", retendo a carga inconsciente do termo. 
adquiridos e apreciados. Não somente podem ser caros, mas também o conhecimento dos alimentos que são julgados autênticos, junto com a própria capacidade de apreciar o que os separa dos alimentos não autênticos, requer um investimento de tempo e um conjunto de habilidades cognitivas e estéticas geralmente presentes em segmentos de elevada escolaridade e renda. (JOHNSTON \& BAUMANN, 2015, pg. 83) ${ }^{157}$

Segundo os mesmos autores, delineia-se um novo perfil de consumidor que evita o esnobismo à francesa e que busca, no contato com a comida não proveniente da elite tradicional, resgatar a verdadeira autenticidade da prática alimentar. ${ }^{158}$ Em uma reportagem, lê-se que os foodies contemporâneos buscam pela autenticidade e que "o que torna uma comida autêntica é o quão tradicional ela é, não o quão cara". ${ }^{159}$ Ainda que isso alimente um discurso democrático e inclusivo, há a persistência da marcação de status, na medida em que essa procura por comida é seletiva e pautada por novos critérios de afirmação social. Dessa forma, novas fronteiras simbólicas são erigidas entre aqueles que sabem manejar o ecletismo e aqueles que não sabem ou não tem as condições econômicas e culturais para serem ecléticos. Há, portanto, uma tensão no ar. No limite, todo gosto, como nos mostrou Bourdieu, funciona como um recurso excludente, um recurso propício de servir à estratificação social e à diferenciação social. O que podemos observar é que o desejo democrático em favor da maior inclusão, ou por outra, o cosmopolitismo culinário expresso na ampliação do leque de produtos dignos, convive com a persistência de privilégio cultural e econômico daqueles que conseguem comer fora do sistema industrial

157 "And yet authentic foods can be quite difficult to acquire and appreciate. Not only can they be expensive, but also knowledge of foods that counts as authentic, and the ability to appreciate what sets them off from inauthentic foods, requires an investments of time and a set of cognitive and aesthetic skills that generally accompany higher education and income levels."

158 Evidência dessa transposição valorativa é a fala de Michel Bras, famoso chef de um restaurante localizado na região de Aveyron na França e que adquiriu três estrelas Michelin em 1999: "Sempre quis desmistificar a gastronomia. Na verdade, não gosto desse termo, que sempre foi um sinônimo de luxo à mesa - você não poderia comer bem se não tivesse produtos como caviar, lagosta. Não é nada disso: lembro da comida da infância, com os ingredientes e básicos que me alegravam imensamente." (ORENSTEIN, José. "Michel Bras: 'Não gosto do termo gastronomia”'. Estadão, Paladar, 05 nov. 2014).

159 "Contemporary foodies search for authenticity. What makes cuisine authentic is how traditional it is, not how expensive" (FONAROW, Wendy. "Ask the indie professor: Is food the new indie rock?". The Guardian, February 18, 2011). 
de comida. ${ }^{160}$ Esse diagnóstico vai ao encontro daquilo que alguns autores vêm chamando de "consumo onívoro", na discussão sobre o perfil de gosto das elites contemporâneas. A ideia é basicamente a de que houve uma mudança na base da afirmação de status das elites: a postura da "exclusão esnobe", baseada em modelos culturais eurocêntricos, foi substituída por uma postura mais branda que preza pela "apropriação onívora" da cultura, misturando elementos de diversos gêneros e origens (PETERSON \& KERN, 1996, pg. 900). ${ }^{161}$ Eis, pois que a oposição entre alta cultura e baixa cultura (cultura erudita/popular, gosto puro/bárbaro), que Bourdieu constatou ser visceral para a compreensão das trocas simbólicas próprias à sociedade francesa dos anos 1970, sai de cena em favor do ecletismo como modelo legítimo das práticas de consumo.162 Os autores Peterson e Kern (1996) chegaram a essa conclusão com base na análise estatística das preferências musicais das classes norte-americanas. Todavia, a hipótese foi sucessivamente testada por outros autores em outros domínios empíricos, sendo a maior parte desses estudos publicada na revista americana Poetics: Journal of Empirical Research on Culture, the Media and the Arts. ${ }^{163}$ Os autores Johnston \& Baumann (2015), que escreveram sobre os foodies, também se apropriaram da noção, reformulando-a como resultado da tensão entre a ideologia

$160 \mathrm{Se}$, como admite o próprio Bourdieu, existir uma forma genérica de capital cultural que unificaria todas as formas particulares (música, pintura, literatura, esporte, comida, escolhas políticas, decoração, etc.), a possibilidade de o gosto por comida repercutir em atribuições de status é justamente dada pela grandeza da distância que se estabelece em relação ao reino das necessidades, ou melhor, às urgências da luta material pela sobrevivência. Quanto mais supérflua, mais legítima é uma atividade cultural, por corporificar uma soma de tempo devotada apenas a aprender a maneira correta de se consumir o que quer que seja. Tributário da sociologia do conhecimento, o que está em jogo aqui é a ideia de um coeficiente de aprendizagem que se encontraria materializado nas práticas e nos objetos de consumo (HOLT, 1997). Ora, se concebido conforme esse esquema formal, seria o consumo de café, hoje, parte do consumo cultural?

161 O termo onívoro designa aquele animal que come de tudo, ou seja, não possui uma dieta restrita (animal ou vegetal). O termo é transposto no sentido metafórico para o domínio cultural mais amplo, designando aquele sujeito que não consome apenas as formas consagradas da cultura erudita (música clássica, teatro, ballet, galerias de arte, opera, etc.), mas uma diversidade de gêneros culturais. Em termos musicais, por exemplo, os membros das parcelas abastadas da sociedade passam a consumir também rock, jazz, rap, folk, reggae, hip hop, eletrônica, etc. No final do século XX, essa tendência se intensifica ainda mais, como demonstra a comparação entre questionários aplicados em 1982 e 1992 pelos autores Peterson e Kern (1996), os mesmos autores que forjaram o conceito de "consumo onívoro".

162 Não obstante, os autores reconhecem a possibilidade de conciliar o modelo bourdieusiano com essas novas descobertas empíricas, pelo caráter genérico que assume a noção de disposição estética no autor francês: "Bourdieu (1979), for example, contrasts unreflective consumption for personal enjoyment with intellectualized appreciation. He identifies intellectualized appreciation in ways that most easily fit a monolithic symbolic landscape appropriate to the era of the elitist snob. Nonetheless, the culture of critical discourse (Gouldner 1979) central to bourdieu's view is also amenable to a discriminating omnivorousness if the ethnocentrism central to snobbish elitism is replaced by cultural relativism. Under these conditions, cultural expressions of all sorts are understood in what relativists call their own terms." (PETERSON \& KERN, 1996, pg. 904).

163 Além disso, outros autores chegaram a noções similares por outras vias, Cf. LAHIRE, 2007. 
democrática e a ideologia de status e distinção, ambas operantes nas práticas alimentares contemporâneas:

O consumo cultural onívoro, não apenas em comida, mas em todas as formas de cultura, é uma maneira de se negociar a tensão entre democracia e distinção na nossa sociedade. $\mathrm{O}$ esnobismo está fora de moda, mas talvez a hierarquia nunca fique fora de moda, e o método contemporâneo para atender a essa demanda conjunta de democracia e de distinção é a postura onívora, que define a qualidade da cultura não pelos gêneros de produto, mas por um foco na autenticidade. (JOHNSTON \& BAUMANN, 2015, pg. 85) ) $^{164}$

Com isso, a busca por status não é abandonada, apenas se realiza através de outras estratégias. Sem dúvida, o modelo de consumo onívoro atinge predominantemente os grupos que possuem elevados níveis de renda e educação; todavia, sua influência não se restringe a esses segmentos. Como bem sabemos, desde o século XIX os padrões artísticos europeus se disseminaram, de cima para baixo, para diferentes parcelas da sociedade, em razão do princípio de emulação cultural. Hoje, é como se o esnobismo entrasse fora de moda. O apreço pela diversidade e pelo relaxamento dos códigos mais rígidos de comportamento são valores que ultrapassam as fronteiras de classe. A consequência disso é que a sede de dissimulação foi generalizada para todos os estratos sociais, sem perder o traço corporativista da busca incessante pela segmentação dos gostos e das opiniões (PASSERON, 1995). A bem verdade, os novos valores da autenticidade ou da diversidade sensorial, para nos restringirmos ao plano da comida, nunca permanecerão nesse plano abstrato e formal de afirmação da distância em relação à postura esnobe rigorosa. Sua existência concreta sempre tomará feições específicas, o que quer dizer conteúdos determinados à luz dos contextos práticos de atuação social. Ainda que valorize as comidas provenientes das minorias étnicas e da classe trabalhadora, o discurso culinário atual rejeita o modelo do fast food como não autêntico, desconsiderando o fato de as refeições rápidas e fáceis funcionarem como adaptações ao ritmo precário das classes menos abastadas. ${ }^{165}$ Há,

164 "Omnivorous cultural consumption, not just in food but in all forms of culture, is a way of negotiating tension between democracy and distinction in our culture. Snobbery is out of fashion, but hierarchy may never be out of style, and the contemporary method for meeting the demand of both democracy and distinction is omnivorousness, which defines quality in culture not by genres but by a focus on authenticity."

165 Segundo Johnston \& Baumann (2015), isso se dá porque a comodidade do fast food não preenche os ideais da classe média, que veneram o "tempo de qualidade" (pg. 191). 
portanto, uma seletividade na maneira em que os gostos misturam elementos da alta cultura e da cultura popular nas práticas contemporâneas de "ecletismo" gastronômico. O consumo onívoro sempre tomará formas específicas, a depender do contexto histórico e das flutuações momentâneas das modalidades de consumo. Isso explica por que a prosperidade do "gourmet", enquanto modo de consumo, se estabelece ao mesmo tempo envolta por uma atmosfera de ambiguidade e hesitação. No caso do café, a abertura das classes para a diversidade dos modos de preparo da bebida, que é uma tendência no setor, é acompanhada pela delimitação de novos padrões de gosto afeiçoados a determinados sabores e gestos, sendo a bola da vez o coado (de preferência no porta-filtro japonês Hario V-60) e a torra clara do grão. As cafeterias, a nosso ver, estão definindo os parâmetros do atual "consumo onívoro" de café, que não opera mais numa lógica funcional (cafeína ou sociabilidade) e não pertence inteiramente ao ideal de "aparato gastronômico" pomposo herdado da tradição aristocrática francesa.

As cafeterias estão entre os estabelecimentos que mais cresceram com a gourmetização; sabe-se que o consumo fora de casa de café cresceu 307\% de 2003 a 2008. ${ }^{166}$ Estimativa da Abic (de 2010) aponta que existem 3.500 cafeterias hoje no Brasil. Desde 2000, um novo perfil do negócio surge em meio a um cenário mais amplo de novos espaços destinados ao prazer gastronômico. Em São Paulo, segundo dados do Instituto Gastronomia, as categorias de estabelecimentos gastronômicos que mais cresceram nos últimos dez anos foram, em primeiro lugar, as hamburguerias, que cresceram em número $575 \%$, seguidas pelas temakerias e locais de sushi, que cresceram 330\%. ${ }^{167}$ Desde 2013, os food trucks também entraram em voga, trazendo a "comida de rua" para dentro dos holofotes. Diz-se que, em 2015, haverá 500 carros só nas ruas de São Paulo, onde havia por volta de 80 em meados de 2014. Todos esses estabelecimentos convergem no tocante ao modo como é qualificada a qualidade do serviço oferecido. Costuma-se valorizar ingredientes raros, cuja proveniência seja especificada na hora da apresentação do produto, além da autenticidade na forma de preparo, o que confere caráter gastronômico ao serviço.

\footnotetext{
166 AMORIM, Diego. “Alto poder aquisitivo dos brasilienses atrai comércio especializado em café". Correio Brasiliense, 24 out. 2011.

167 FELITTI, Chico. "Hamburguerias viram hit em SP e número de casas gourmet cresce 500\%". Folha de São Paulo, 14 set. 2014.
} 
Uma reportagem do Estadão, "Colhido no supermercado", nos mostra em que medida essas transformações gastronômicas, provenientes do setor de serviços, podem repercutir nas prateleiras de supermercado. Na capa da reportagem, lê-se o seguinte diagnóstico: “O café trivial mudou. Ainda não é aquele de barista, mas está melhor do que era. Agora, entre a bebida rotineira e as especiais há produtos intermediários nas gôndolas". Com a ajuda de especialistas, o jornal avaliou 12 rótulos entre superiores e gourmets de grandes torrefadoras, deixando a mensagem de que "é possível melhorar nossa xícara de cada dia". A tendência apontada é que mesmo as grandes marcas, que vendem café em grandes quantidades, migrem para as categorias mais refinadas da bebida, o "superior" ou o "gourmet", segundo as categorias da Abic, que apresentam menor proporção de grãos defeituosos e maior complexidade de sabor. Na primeira parte da reportagem, os empresários do setor são questionados para falar sobre o perfil de sabor do café comercializado. Os fabricantes do Três Corações e do Pilão dizem que seus produtos se alinham ao padrão que prevalece no gosto do brasileiro, seguindo a reportagem:

As grandes torrefadoras investem para manter o padrão do café no gosto do brasileiro, "forte e encorpado", segundo Gilberto Nogueira, responsável pela qualidade e desenvolvimento da Três Corações.

Mas nosso café é assim por que a gente gosta ou a gente gosta assim por que é o que tem? "Eu diria que o brasileiro gosta de café forte, encorpado e amargo, com bastante robusta", diz Ricardo Souza, da Master Blender, fabricante do Pilão. (Redação Estadão. "Colhido no supermercado". Estadão, Paladar, 29 jan. 2015.)

Já no discurso de João Michaliszyn, da Melitta, a coisa muda um pouco de figura. Segundo a reportagem, a marca acredita "no potencial pedagógico dos cafés superiores para superar as noções de fraco, forte e extraforte ao escolher o que levar para casa". Dessa forma, o forte e encorpado deixa de ser uma certeza, mesmo para a produção industrial do café. No fim de 2008, a Melitta lançou a linha de cafés Regiões Brasileiras, com matériaprima proveniente de três regiões produtoras: Cerrado, Sul de Minas e Mogiana. A concepção da linha era basicamente tornar acessível ao consumidor de supermercado a possibilidade de perceber nuances de sabor vinculadas ao lugar de origem do produto. A nosso ver, é como se tratasse de uma aplicação prática e industrial do princípio gastronômico do terroir: a ideia de que o clima, o solo, a latitude e a longitude interferem 
nos atributos do produto final, à maneira do vinho. Nesses casos, o padrão de gosto do brasileiro, "forte e encorpado", deixa de ser tomado passivamente e passa a ser negociado nas próprias instâncias do mercado, conforme expresso na fala de João Michaliszyn, gerente de marketing de bebidas da Melitta:

"Lembro de que em alguns casos era preciso ter cuidado quando falávamos de acidez porque o consumidor poderia achar que aquilo é uma coisa ruim." Não é. "é um trabalho de formiguinha levar esse conhecimento ao público." (Redação Estadão. "Colhido no supermercado". Estadão, Paladar, 29 jan. 2015.) $)^{168}$

168 É interessante notar como o discurso da Melitta, nesse aspecto, se coaduna com o discurso de alguns baristas. Reflexões similares aparecem, por exemplo, na fala de Otávio Linhares, consultor do Rause Café +Vinho em Curitiba e campeão brasileiro de baristas em 2005, em outra reportagem do Estadão, acerca dos seus objetivos de carreira no mundo do café: "Fazer a população do maior produtor de café do mundo, mas analfabeta sobre a bebida, entender e valorizar o que vai na xícara" (ORENSTEIN, José. “Torrar ou não torrar?”. Estadão, Paladar, 26 fev. 2014). Em outra ocasião, o barista havia dito o seguinte: "O café que a gente toma no Brasil é ruim. E é ruim por causa do pensamento industrial". 
Figura 15 - Editorial sobre café no Estadão

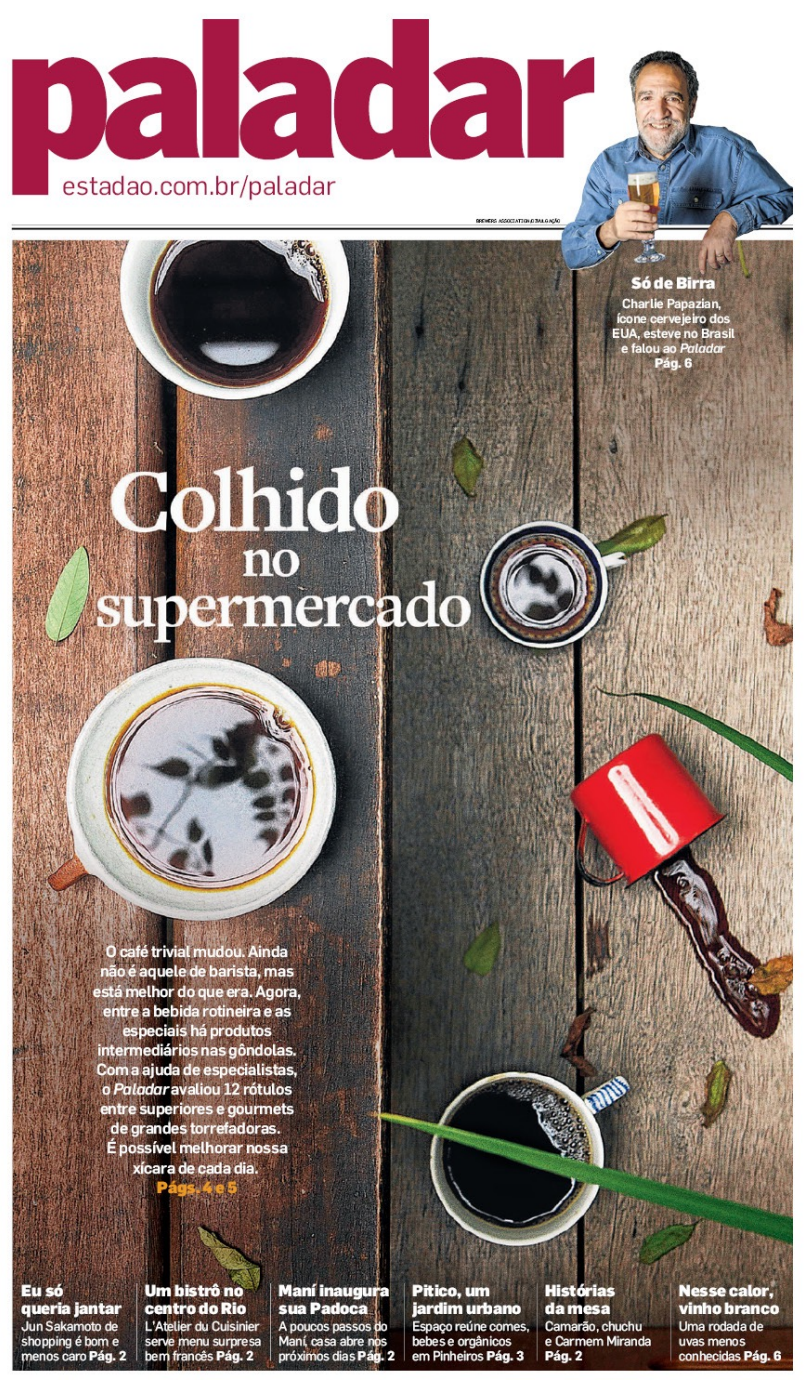

Fonte: print screen do site do Estadão, edição de 29/01/2015

Logo abaixo desse trecho, a reportagem entra no terreno normativo da experiência gustativa e passa a enumerar as características ideais na seção "O que faz de um café um bom café?". Sobre os parâmetros sensoriais, lê-se o seguinte: "Bons cafés devem ter doçura natural, aroma complexo e vivo, corpo, acidez (não o azedume que faz contrair as bochechas) e não devem ser amargos". Mais adiante, também fala-se do perfil ideal de torra: "Grãos de qualidade perdem características quando supertorrados e os defeitos ficam camuflados pelo amargor. Prefira pós com coloração mais para o marrom do que para o preto. Quanto mais escuro for o pó, mais amarga e adstringente ficará a bebida”. Por fim, 
entra a questão das espécies de grão (arábica x robusta): “Com grãos 100\% arábica, a bebida tende a ter menos corpo e mais complexidade. Será mais doce e ácida, mas pode não ter aquele corpo denso". Essas colocações deixam claro que a concepção de qualidade no segmento gourmet vai muito além da utilização de ingredientes melhores, pois mobiliza padrões específicos de gosto que, tendencialmente, entram em conflito com os hábitos alimentares mais arraigados dos consumidores. O café, ao contrário de outros artefatos, não possui uma instância muito definida de legitimação quanto ao padrão de gosto que convém, tal como as críticas gastronômicas que avaliam restaurantes em jornais consagrados. ${ }^{169}$ Vale dizer que a conformação do gosto nesse segmento ocorre de forma mais difusa do que em outros campos de produção cultural, como o campo artístico propriamente dito. Não há dúvidas de que existem grupos de especialistas em ação, mas esses especialistas não estão organizados em torno de revistas especializadas ou em cadernos fixos da imprensa dos jornais. A maior parte da normatividade é exercida nos próprios espaços de consumo do café, sendo as cafeterias os locais de capitalização do corpo gourmetizado. Há revistas de café que se destacam, à exemplo da Revista Espresso, mas elas (ainda?) não constituem meios fundamentais de irradiação do conhecimento gustativo especializado. São os baristas, como visto no capítulo anterior, que funcionam como as figuras centrais desse novo saber que traduz a apreciação rigorosa do alimento, própria ao universo da degustação gastronômica, em práticas diárias nas quais o café deixa de ser apenas uma bebida funcional. Se quisermos entender o papel que os bens marcadores de status possuem na economia de serviços, devemos nos dirigir aos prestadores de serviço em sua prática diária. Foi exatamente o que tentamos fazer no nosso trabalho de campo na cidade de São Paulo. A seguir, focaremos no material recolhido no Centro da cidade, pois acreditamos que essa localização intensifica algumas tensões importantes a serem abordadas sociologicamente.

169 Por exemplo, uma reportagem no site coffeegeek (termo que designa os maníacos por café) dedica-se a criticar os agentes da indústria de café por não incentivarem o desenvolvimento de uma cultura especializada entre os consumidores, como o fazem os profissionais do vinho, que, segundo o autor, organizam eventos só para os consumidores, abrem as portas de suas vinícolas, oferecem sessões de degustação de graça, e assim por diante. Some-se a isso a ausência de programas de televisão destinados ao café ou de revistas especializadas que escrevam sobre os cafés que estão em alta e os que estão em baixa na estação, tal como se faz com os vinhos. Em dado momento da reportagem, o autor declama: "Eu quero a minha revista 'The Coffee Connoisseur', droga", em alusão à revista de vinho Wine Connoisseur (PRINCE, Mark. "So what the heck is wrong". CoffeeGeek, February 06, 2005). 
Há algum tempo, o Centro de São Paulo vem sendo transformado por aquilo que chamam de "gentrificação", a transformação urbana de áreas deterioradas e sua substituição por estabelecimentos e residências destinados às classes médias e altas. No quesito cafeterias, o Centro ganhou dois novos estabelecimentos desse porte entre Dezembro e Janeiro de 2015, o Café Beluga e o Por um Punhado de Dólares. No período em que passei em São Paulo, fui visitar esses dois estabelecimentos para ver como andavam as primeiras semanas. Como se já não bastasse o nome, o Por um Punhado de Dólares tem um subtítulo, "cafés sinceros". Conversando com um dos donos, descobri que a intenção era fazer uma coisa mais acessível, sem muita frescura, mas ao mesmo tempo com grande atenção para a qualidade. $\mathrm{Na}$ conversa, ele tocou no nome da Isabela Raposeiras, a dona do Coffee Lab, como sendo uma figura central no mercado de cafés em São Paulo, mas que pecava pela postura pretensiosa, por querer valorizar os cafés especiais em detrimento do café comum ao qual o consumidor está acostumado. Nas palavras do sócio: "É preciso ter cuidado com essa coisa de cafés especiais, pra não achar que tem uma fronteira entre isso e o café comum". Depois de mais alguma conversa, ele revelou que acredita sim na tarefa de disseminar café de qualidade, mas sem "oportunismo de mercado", sem contribuir para consolidar uma fronteira elitista entre esses cafés e o café ordinário. 
Figura 16 - Reportagem da Folha de São Paulo

\section{comida}

São Paulo, 461

\section{Aluguel barato atrai bares $\mathrm{e}$ restaurantes 'hipsters' para o centro}



José Tibiriçá, o Tibira, no Armazém Alvares Tibiriçá, na Santa Cecilia

BRUNO FÁVERO

DE SÃO PAULO

25/01/2015 $\odot 02 h 00$

Fonte: print screen do site da Folha de São Paulo, edição de 25/01/2015 
Figura 17 - A cafeteria Por um Punhado de Dólares no centro de São Paulo
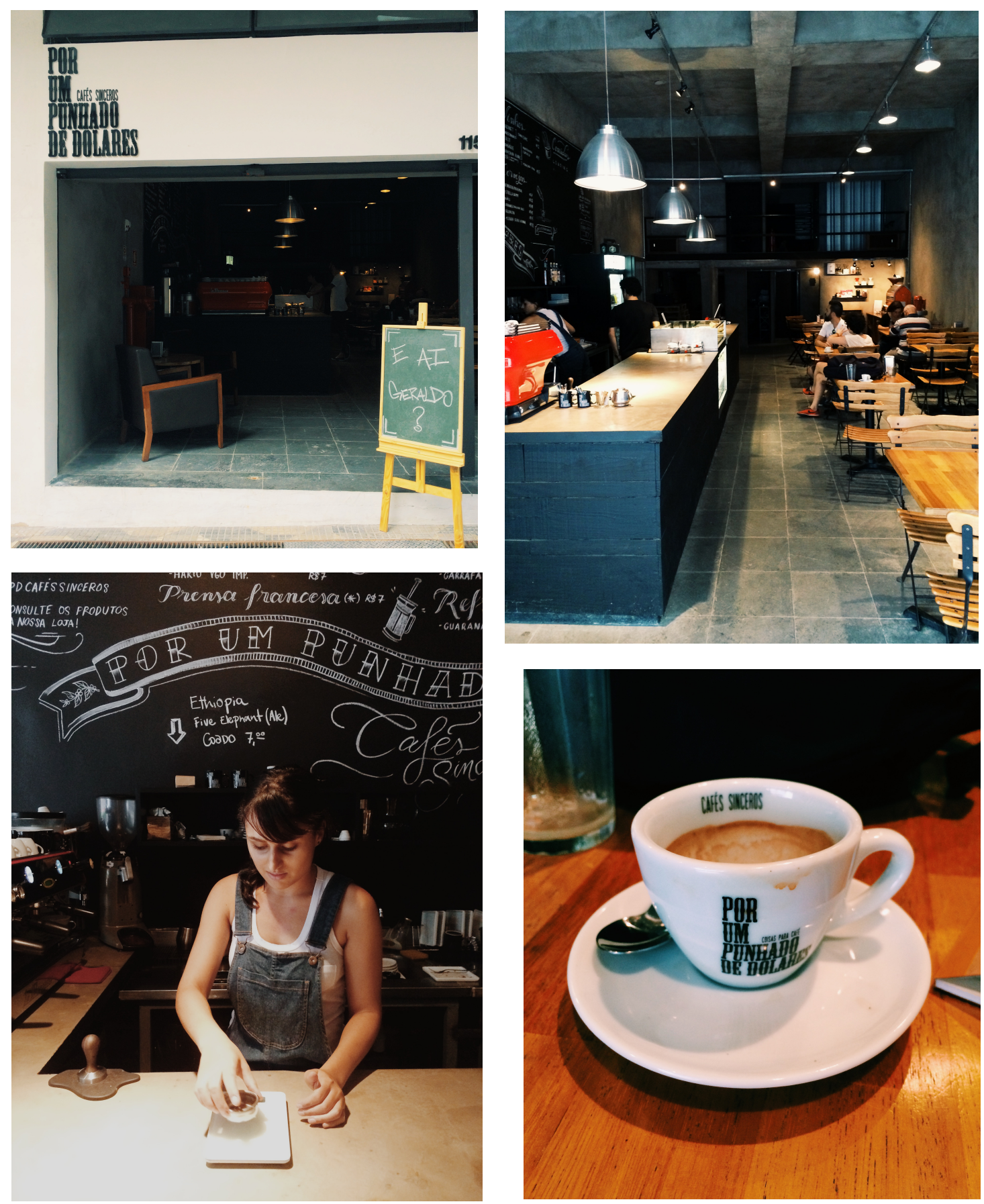

Fonte: fotografias elaboradas pelo autor 
Figura 18 - A cafeteria Beluga Café no centro de São Paulo
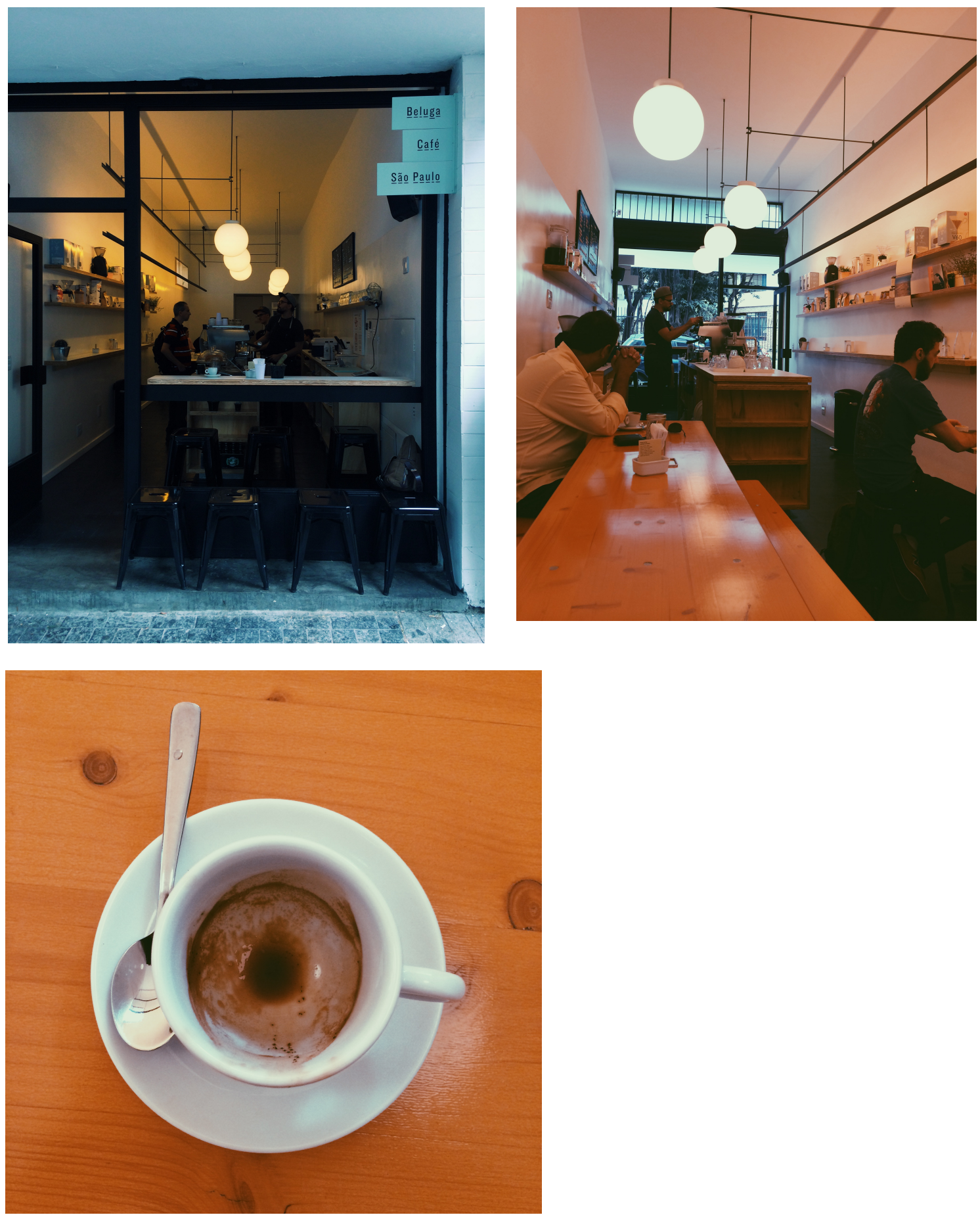

Fonte: fotografias elaboradas pelo autor 
No dia em que visitei a cafeteria, uma mulher cuidava do preparo dos cafés e da máquina de espresso, enquanto um segundo sócio ficava no caixa. A mulher barista comungava da mesma opinião dos donos do estabelecimento: segundo ela, Isabela Raposeiras prega um estilo bem específico de café (torra clara/coado/ácido) e toma como "verdade absoluta" o que deveria ser tratado apenas como mais uma modalidade de consumo. Se o brasileiro é mais acostumado com um outro perfil de café (torra escura/ robusta/amargo), por que devemos criticar o consumidor por isso e forçá-lo a entrar em determinado padrão de gosto? Nas suas palavras: "E se o cara gostar de torra escura? Vamos fazer, vamos provar". Ao conversar com um dos sócios, descobri que a intenção que estava no nome do estabelecimento (Por um punhado de dólares, cafés sinceros) era de "mexer com o sistema". Essa postura irreverente também se estendia à placa que ficava na porta de entrada e que, naquele dia, estava com os dizeres “E ai, Geraldo?" - em alusão à falta d'água na cidade e à parcela de responsabilidade do então governador de São Paulo sobre a situação. O problema é que muitas pessoas que passavam pelo estabelecimento não entendiam o significado de "E ai, Geraldo?" e não raro perguntavam o que era. Em determinado momento, a barista falou para o sócio que ficava no caixa: "A gente tem que trocar essa placa, que o povo não tá entendendo nada!", o sócio, um pouco agoniado, disse: "aqui no centro só tem doido", pouco depois acrescentou: “é uma provocação! Não precisa entender tudo, né?". Em outro momento, chegou um amigo da barista e começou a bater papo com ela, enquanto ela preparava alguns cafés para os clientes. Assim que ficou mais livre do serviço, ela resolveu preparar dois cafés especiais para o amigo, momento no qual presenciei o seguinte diálogo:

- Vou colocar açúcar, Nah

- Não! Tô te proporcionando uma degustação e você vai colocar açúcar

Seguindo a repressão da amiga, o rapaz não adoçou o café, e ficaram ali por alguns instantes conversando sobre as diferenças entre os dois cafés, até que o rapaz disse qual café ele gostou mais. Pouco antes, eu já havia conversado com ela sobre as diferenças sensoriais entre os cafés que eles vendiam, momento em que ela me perguntou:

- Você já provou café da Etiópia? 
- Sim, mas eu não consigo perceber a diferença assim por regiões produtoras

- Ok, mas e sensorialmente?

- Sim, claro. É mais ácido, né?

- É uma acidez diferente

E aí ela começou a descrever os tipos diferentes de acidez que se pode perceber ao degustar um café - e por algum tempo ficamos ali avaliando qual acidez era a mais preponderante naquele café, se a acidez fosfórica ou a lática, a primeira com "gosto de coca-cola quente nos dentes" e a segunda com "gosto de leite", que "desliza" na língua, segundo sua explicação. Contente com a interação, resolvi provar o tal café da Etiópia que eles ofereciam, chamava Five Elephant e custava 7,00 reais, enquanto os outros grãos custavam 5,00 a xícara. ${ }^{170}$ Depois de provar o café, cheguei a comentar com um dos sócios que aquele café da Etiópia deveria ser chamado de "Por uns dólares a mais". ${ }^{171}$ Ele riu e me falou que eles brincavam entre si que esse seria o nome da próxima filial da cafeteria.

Vale notar que a própria cafeteria torrava seus grãos - e lembrem que essa é uma tendência da chamada terceira onda do café. Eles compravam os grãos verdes em saca e alugavam uma máquina de torrefação para torrar, de uma só vez, uma grande quantidade. A primeira saca havia sido comprada da fazenda Santa Lina, que, segundo a barista, "tinha no Suplicy há um tempo atrás”. Também há uma máquina de torrefação na loja, a ideia é poder torrar no futuro pequenas amostras para vender para os clientes, enquanto que o grosso da loja continuaria vindo da máquina que eles alugavam em outro lugar. Sobre essa questão da torra própria, um dos donos me disse que, por mais que o Coffee Lab fosse bastante conhecido pela sua torrefação, quem "faz a diferença no mercado" é a Suplicy que deve vender cerca de 7 toneladas de café por mês, mais ou menos, enquanto o Coffee Lab trabalha somente com umas 7 sacas por mês, cada saca pesando $60 \mathrm{Kg} .{ }^{172}$ Disseminar café de qualidade, essa era a tópica que movia a fala de um dos sócios entrevistados, fazer a sua

170 O autor Edward Behr (1992) descreve as características gerais de um café da Etiópia: "Like most Ethiopian coffee, it is washed, which enhances its naturally generous acidity. The flavor stands out for cleanness, brightness, balance, complexity, and a unique aftertaste of lemon peel, rising to the nose. It is, by consensus, the most flowery of all coffees." pg. 228-229.

171 Por um punhado de Dólares (1966) é o nome do primeiro filme da trilogia de westerns dirigida pelo italiano Sergio Leone, seguido das continuações Por uns dólares a mais e Três homens em conflito.

172 No curso de barista do Coffee Lab, o professor Renato nos disse que lá eles não fazem uma torra artesanal, mas uma "torra industrial pequena". Com mais ou menos 5 anos de vida, o Coffee Lab já foi eleito uma das cinco melhores torrefadoras do mundo. 
parte em um mercado que, em suas palavras, é "gigantesco", e a partir daí oferecer "cafés sinceros".

Enquanto a maioria das cafeterias gourmets de São Paulo aposta no café de torra clara, em especial destaque o Coffee Lab, o Sofá Café e a cafeteria Torra Clara, a cafeteria do centro Por Um Punhado de Dólares aparece como uma contra-tendência. É o que diz a reportagem da Folha de São Paulo, intitulada "Cafeterias novas apostam em grãos torrados sob encomenda":

Sobre o balcão, um aviso deixa claro aos clientes a proposta dos donos Marcos Tomsic e Felipe Yabusaki: "Torra escura - café amargo como a sua vida". A mensagem combina com o nome da casa, que homenageia um lendário faroeste italiano. Tomsic se diz alheio a tendências e defende o amargor como característica do paladar brasileiro. A torra é feita por terceiros, mas em breve ele pretende fazer funcionar a pequena torrefadora que está exposta no salão. (PEDROSO, Paulo."Cafeterias novas apostam em grãos torrados sob encomenda". Folha de São Paulo, Comida, 06 mar. 2015.)

A outra cafeteria que abriu as portas no centro de São Paulo foi o Beluga Café, um lugarzinho pequeno não muito longe da praça da República. O barista de lá, que pelo que entendi é também o dono da cafeteria, recebeu treinamento no Coffee Lab e quando cheguei no estabelecimento era ele quem estava operando a máquina de espresso. Pedi um espresso, sentei e comecei a investigar o ambiente. Pouco depois, presenciei uma cena que considero heurística para se entender os desdobramentos práticos da gourmetização. Um freguês entrou no estabelecimento e pediu um espresso fazendo um gesto de que queria mais longo. Mencionou que queria longo mas também mais forte. O barista então explicou que haviam duas opções: ou ele fazia um duplo (que são duas medidas daquele espresso pequeno de $30 \mathrm{ml}$ ) ou fazia um curto e acrescentaria água para diluir (o chamado "café carioca"). O sujeito optou por diluir com água, mesmo com a ressalva do barista de que poderia ficar aguado. Dito e feito. O sujeito recebeu o café, tomou e reclamou que estava ruim e "aguado", tirou uma nota de 10 reais para pagar e disse que aquela era a segunda vez que estava dando chance à cafeteria, pois haviam lhe dito que aquilo era café de qualidade. $\mathrm{O}$ barista se recusou a receber o dinheiro. $\mathrm{O}$ cliente insistiu. $\mathrm{O}$ clima ficou um pouco tenso entre os dois, deu para perceber a cara de irritado do barista. As coisas pioraram de vez quando o cliente disse a seguinte frase antes de ir embora: "você não tem 
que vender o que você quer, mas o que eu quero comprar". Depois que o cliente foi embora, o barista começou a conversar sobre o ocorrido com dois outros clientes e comentou o seguinte:

- É complicado, porque café o cara pode ir em qualquer padaria e o café vai ser feito de qualquer jeito

A ideia era de que aquele era um estabelecimento que se esforçava para fazer um "café de qualidade" e que, para alguns consumidores, o gosto do café poderia parecer estranho porque não era familiar, não era igual ao "café da padaria". Um dos clientes, tentando reconfortar o barista, disse o seguinte:

- É como comida, nos anos 80 tinha muito pouco restaurante de alta qualidade, aí o chef podia fazer o que quiser que era a única coisa que tinha. Hoje, como tem muito, a coisa muda

- É, com o café ainda vai demorar [respondeu o barista, ainda pessimista]

- Sim, até porque as pessoas fazem em casa, então elas acham que entendem daquilo, querem do jeito delas (...) café é uma coisa familiar pra elas [acrescentou o terceiro cliente]

Depois de alguns minutos, a atmosfera acalmou e logo os três estavam fazendo piada sobre clientes que pedem macchiato (café espresso com leite vaporizado) com muita canela: "E é chá de canela?". Os três riam entre si e amenizavam o clima pós-conflito. A situação, como um todo, só pode ser devidamente compreendida se colocarmos as idiossincrasias individuais do barista e do consumidor dentro de um plano maior, no qual entra em jogo o conflito entre diferentes padrões de gosto. De um lado, há o gosto representante do mercado de luxo do café, que vem crescendo bastante nos últimos anos e que toma feições parecidas com a gastronomia, baseada na expertise dos chefs de cozinha; esse padrão de gosto, no interior da materialidade do café, é marcado pela exaltação da acidez da bebida e, se possível, pela presença de notas florais e frutadas. Do outro lado, temos o cafezinho trivial do brasileiro, admirado pelo seu sabor encorpado e amargo. ${ }^{173}$

173 Sensorialmente falando, essas duas características fortes, o corpo e o amargor, andam bem com o hábito de adoçar o café, posto que o açúcar "nivela" o sabor da bebida. Em outras palavras, o açúcar pode obscurecer os sabores de pouca presença e, nesse sentido, seriam necessários sabores que conseguissem, a despeito desse fato, atravessar e ganhar destaque no resultado final. Esse padrão se estabelece de tal maneira que chega a se naturalizar também na fala das pessoas, sendo percebido como a única forma correta de se tomar café: "Mas quem gosta de café, gosta de amargo, né?", nos indagou um dos entrevistados. 
Delineia-se, assim, uma dicotomia que resulta do surgimento de novas instâncias de treinamento e de capacitação do mercado. Isso se dá no exato momento em que surgem novos agentes, dentre eles o barista, e uma nova hierarquia se estabelece a partir daí, ainda que em fase de legitimação. São especialistas que portam um know-how adquirido e que se defrontam, na prática de trabalho, com outros imperativos de gosto, o que pode resultar em conflitos tais como o presenciado no Beluga Café.

Figura 19 - Esquema do conflito observado da ordem do gosto



Fonte: elaborado pelo autor

Uma das coisas interessantes de serem comentadas, e sobre a qual os questionários nos trouxeram luz, diz respeito à relação entre a capacidade de discernimento sensório a nível formal e a circulação concreta de sabores específicos. Anteriormente, pensávamos que o circuito gourmet, com toda a estrutura institucional de cursos e especializações voltadas para o barista, estava contribuindo para desenvolver uma capacidade formal de degustação entre os amantes de café - e mais ou menos a mesma coisa estaria acontecendo com a cerveja e com outras categorias alimentícias. Ao longo da pesquisa, percebemos que esse é apenas um dos lados do processo, pois a reconfiguração do mercado gastronômico envolve também transformações socio-materiais e sensório- 
perceptivas, e esses dois planos estão vinculados à delimitação de novos regimes de gosto. Nesse sentido, percebemos que há uma espécie de guerra atualmente em jogo envolvendo certos sabores. No caso do café, os conflitos mais evidentes dizem respeito à contraposição entre o amargor e a acidez presentes na bebida e que são desigualmente distribuídos entre as variedades de preparo da bebida. Assim, no caso do Beluga café, o que estava em jogo também era a disjunção entre o café mais "forte" (amargo) do consumidor e o café mais ácido oferecido pelo estabelecimento. Antes de ser um conflito entre o know-how apreciativo daquele que sabe discernir os componentes intrínsecos aos alimentos e o saber "automático" do consumidor leigo, a situação reproduz o conflito entre duas formas consagradas de apreciação. Em outros termos, antes de se constituir o problema das condições de desenvolvimento formal da capacidade perceptiva humana, numa era repleta de fundamentações técnicas e científicas, é preciso ressaltar o papel que cumpre a circulação de diferentes padrões de gosto ao longo do tempo. Seguramente, o conhecimento técnico-especializado (connoisseurship) do produto, aptidão que virou moeda de troca depois da institucionalização da profissão barista, envolve aspectos de ordem reflexiva e deliberativa. É possível dizer que as pessoas que investem nessa capitalização o fazem no intuito de organizar suas tomadas de decisão. Michel Callon e Muniesa (2003) chamam atenção para o fato dos mercados serem, hoje, altamente reflexivos. Todavia, o consumo "refinado", ainda que acoplado a instâncias cognitivas de decisão e organização, é em grande medida uma disposição de gosto que bebe em fontes inconscientes e se realiza a despeito da tentativa de organização racional. O amargor e a acidez fazem parte dessas fontes que, a nosso ver, apontam para o plano da postura corporal como um todo (hexis), e de cujo contato com os objetos resultam efeitos de realidade, tais como esse senso de precisão gustativa exibido no ato de tomar alguns tipos de café. ${ }^{174}$

Sabemos que usar o café para expressar uma apreciação da diversidade sensorial não é uma experiência compartilhada por todos os segmentos sociais. Apenas uma parcela restrita do espaço social, como é o caso dos frequentadores das cafeterias gourmets,

\footnotetext{
174 A esse respeito, chegam a dizer: "Se fez biquinho, raspou a garganta, arregalou os olhos, é gourmet” (CHAPOLA, Ricardo. "Crônica gourmet”. Estadão, Vida \& Estilo, 29 maio 2014).
} 
participa ativamente desse processo de simbolização via consumo, de pôr em correlação pessoas e cafés, tornando palpável a unidade e a potência da ideia de estilo de vida. Os indivíduos do circuito do café de alta-qualidade tomam café como se eles próprios fossem cafés de alta qualidade se diferenciando de cafés inferiores, como o coado tradicional e o pingado. Não podemos nunca esquecer que a natureza conflitiva dos grupos sociais se realiza também na relação que eles possuem com as coisas cotidianas, ou mesmo, mais especificamente, na função que um mesmo artefato pode desempenhar para cada grupo. O café também opera segundo essa lógica de diferenciação social. Alguns usam o café de um jeito, para trabalhar, para produzir, servindo de combustível matinal; já outros usam o café como motivo de pausa no trabalho, nos estudos, há aquela expressão em inglês, coffeebreak, um pretexto para fumar um cigarro, para conversar, para relaxar e logo em seguida voltar a trabalhar. Hoje, há uma modalidade de consumo de café que está em via de expansão e que, de certa forma, condensa em si todo um repertório de mudanças na organização do mercado gastronômico. É o consumo de café como forma de experimentação sensorial, uma espécie de desafio prático para o aparato sensorial dos indivíduos consumidores através de uma postura de abertura a "novos sabores". Trata-se de uma forma de consumo de luxo na medida em que pressupõe o afastamento das necessidades básicas e envolve uma atitude de ócio. É como a disposição estética descrita por Bourdieu n'A Distinção, uma postura que se sustenta a partir de certas condições de classe que permitem uma experiência do mundo desembaraçada da urgência, uma inclinação e aptidão para a prática sem função, gratuita e desinteressada. Nas palavras de Bourdieu:

O poder econômico é, antes de tudo, o poder de colocar a necessidade econômica à distância: eis porque, universalmente, sua afirmação consiste na destruição das riquezas, no gasto ostentatório, no desperdício e em todas as formas do luxo gratuito. (...) À medida que aumenta a distância objetiva à necessidade, o estilo de vida torna-se cada vez mais o produto do que Weber designa como uma "estilização da vida", expediente sistemático que orienta e organiza as mais diversas práticas, por exemplo, escolha do vinho de determinada safra e de um queijo, ou decoração de uma casa de campo. Enquanto afirmação de um poder sobre a necessidade dominada, ele traz sempre em seu bojo a reivindicação de uma superioridade legítima sobre aqueles que, por não saberem afirmar o desprezo pelas contingências no luxo gratuito e no desperdício ostentatório, permanecem dominados pelos interesses e pelas urgências comuns: os gostos de liberdade só podem 
afirmar-se como tais em relação aos gostos de necessidade que, deste modo, são levados à ordem da estética, portanto, constituídos como vulgares. (BOURDIEU, 2007, pg. 55-6)

Assim, conforme a proposta de Bourdieu, a presença ou ausência dessa capacidade de colocar as urgências da vida em suspensão é uma das fontes primordiais do prestígio nas sociedades atuais: ela define o valor de si aos olhos dos outros, dando espaço para o sentimento de dignidade pessoal existir. ${ }^{175} \mathrm{~A}$ distinção, nesse âmbito, teria por objetivo assinalar a distância que separaria o sujeito dotado de disposição estética da plebe vulgar e grosseira. Isso se expressaria nas seguintes frentes: refinamento das maneiras, estetização do estilo de vida e busca de prazeres delicados (CHARTIER, 1998). Ainda assim, há uma ressalva a ser feita. A postura do consumidor gourmet de café, embora seja modelada pela lógica supracitada da disposição estética, possui grande comprometimento com as diferenças materiais dos produtos, junto com um investimento na capacidade sensória de se apreender as qualidades provenientes da matéria, o que é pouco visível na estética burguesa clássica. Como figura expressiva da reorganização pela qual vem passando a economia de serviços como um todo, o consumidor gourmet é refém daquilo que é colocado diante de si. O encontro entre a sua percepção e o objeto oferecido pelo mercado reverbera na criação de novos parâmetros de distribuição do status em conformidade com as condições materiais ofertadas pelo mercado. Eis, pois, o contexto em que a tônica

175 Na proposta de Max Weber (1982b), a ordem social diz respeito a essa distribuição dos privilégios em termos do sentimento de honra e prestígio vinculado, nesse sentido, ela opera numa dimensão mais espiritual da posição no mundo. Os estilos de vida, que são essas formas culturais diferenciadas no interior da ordem social maior, são exatamente o inverso da posse de bens e de dinheiro, que são as formas que governam a ordem econômica. Com o advento do mundo moderno, torna-se possível sobrepor e aliar essas duas dimensões de acesso ao poder, na medida em que os estilos de vida são, em sua maior parte, economicamente condicionados. Se antes a cultura e a economia eram vistas como duas formas antagônicas de criação dos grupos humanos, hoje, ironicamente, a situação de classe (definida pela possibilidade de se usar, em proveito próprio, bens e serviços no mercado) constitui o fator predominante na formação dos novos estamentos (ou grupos de status). Nesse momento, a luta pela "honra" se mistura à luta pelo dinheiro e, como consequência, as oportunidades ideais e materiais de uma posição no mundo passam a ser orquestradas de forma unificada. O conceito de habitus, em Bourdieu, procura dar conta dessa conjunção de estratégias, no momento em que o mercado se encontra atravessado pela cultura e vice-versa. A arte, embora possua grande potência simbólica, é uma região pequena da cultura (ou da ordem social, para falar como Weber). Bourdieu usa a expressão "disposição estética" para dar conta de um montante maior de práticas que são marcadas pelo ímpeto de espiritualização, essa tentativa de denegar as preocupações de ordem material e transubstanciá-las em problemas de estilo de vida. Não é de se estranhar, pois, que o autor trate, na obra $A$ Distinção, indiscriminadamente os mais diferentes domínios da prática; as preferências em matéria de música, pintura, literatura, política, decoração, vestimenta, alimentação, religião, e assim por diante, todas precisam ser entendidas à luz de um denominador comum. 
mercadológica é depositada na experiência sensorial do consumidor. A gourmetização, por esse ângulo, vem acompanhada do problema da capacitação do consumidor para pôr-se em jogo nesses espaços nos quais objetos e equipamentos são diretamente voltados para a mínima diferença de sabor. Talvez, caso queiramos manter o conceito de disposição estética, seja necessário abrir mão da ideia de que, em seu bojo, a tônica do comportamento é transposta d'o que se consome para como se consome, enquanto fórmula simplificada de análise. Isso porque, no universo da degustação, as diferenças materiais internas aos produtos passam a ser acionadas e são fundamentais para o entendimento dos novos tipos de manifestação de prestígio, como demonstra a cena do Beluga café.

Em certa medida, o consumo de café pode ser entendido como uma espécie de consumo cultural, na medida em que pressupõe a manipulação ativa de saberes especializados e habilidades adquiridas como traços intrínsecos ao próprio ato de consumo, conformando uma espécie de capacitação cultural do corpo. ${ }^{176}$ Assim, não apenas os produtos são comparados na dinâmica mercantil, mas as próprias capacidades de apreciação são postas em jogo como elementos fundamentais para a marcação social da diferença entre os indivíduos como consumidores. Do ponto de vista sociológico, eis, pois, o que informou a presente pesquisa: a pergunta sobre as instâncias mediante as quais diversos tipos de capital são adquiridos e incorporados sob a forma de competências individuais. $\mathrm{O}$ consumo de café aponta para uma forma de capacitação que distingue os indivíduos entre si na medida mesma em que determinados segmentos sociais passam a distinguir os cafés em tipos cada vez mais complexos e sutis. Como consequência, a própria percepção sensorial e motora dos produtos pode vir a ser alterada em sua totalidade, compondo um novo sensório, marcado por características socialmente reconhecidas como "amargo", “ácido”, “frutado”, “floral”, “forte”, “suave”, “encorpado", “doce”, e assim por diante. Walter Benjamin (2012) tem uma reflexão interessante sobre essa questão do estatuto social da experiência sensória. Ele afirma que, em determinados

\footnotetext{
176 Entende-se cultura aqui não no sentido de uma metafísica dos costumes, mas no sentido particularizante de uma tópica de definição que confere relevo simbólico àquilo que perpassa e abarca, em cada caso histórico concreto. Em termos gerais, Cultura refere-se a toda transmissão de toda memória não-genética na experiência humana. Doravante, o uso de cultura como adjetivo aqui possui um significado mais limitado. Trata-se do problema da definição de eixos normativos que conferem status às condutas, compondo uma estrutura de desigualdade que tem sua origem na produção e distribuição do conhecimento, seja qual for a forma que esse conhecimento tome.
} 
momentos históricos, o aparato perceptivo humano precisa enfrentar certos "desafios" e forjar saídas práticas específicas que dêem conta de conciliar as contradições herdadas pelo presente. Conforme ele coloca, são pontos de virada na história. Em seu estudo, Benjamin tomou como objeto o avento da reprodutibilidade técnica na fotografia e no cinema, que a seu ver trouxeram um novo modo de organização da experiência sensorial; não obstante, outros objetos empíricos podem ser pensados à luz dessa mesma formulação. Segundo o autor, a possibilidade de replicar a imagem e de projetá-la sobre a retina eram novidades técnicas que, mediante o "efeito de choque", tendiam a desfazer a "distração" que caracterizava o modo de visão moderno e citadino, ao mesmo tempo em que se adaptava a esse mundo no qual a distração se manifesta como a outra face da hiper-estimulação. Isso explicaria o fato de que, no momento em que objetos antes escondidos do cotidiano ganham proporções inusitadas e se agigantam na tela do cinema, a percepção óptica humana adquire um tipo de tato que não possuía e, assim, o próprio mundo visual adquire uma "tactilidade" (TAUSSIG, 1991). Esse tipo de análise, que envolve diretamente os objetos da vida cotidiana, à maneira daquele empregado por Simmel em 1902, serviu-nos como modelo de inspiração para aquilo que pretendíamos realizar no estudo do café. ${ }^{177}$

É importante ressaltar que nem todos os bens de consumo são heurísticos para se entender o processo de demarcação das relações sociais via consumo, uma vez que alguns bens cumprem melhor a função do que outros. Dentre as bebidas relevantes no processo de diferenciação das classes socioeconômicas, temos o vinho, que já há algum tempo funciona no mercado brasileiro como marcador de diferença social, como podemos associar ao fato de existir uma organização dos especialistas em vinho, os sommeliers, há um certo tempo, sendo a Associação Brasileira de Sommeliers (ABS) fundada em 1983, no Rio de Janeiro, e possuindo seccionais funcionando há mais de duas décadas no Rio de Janeiro e em São

177 No Brasil, há poucos estudos que levem em conta a relação estruturante entre os estilos de vida urbanos e a formação de padrões perceptivos endógenos a esse tipo de convivência social, tanto menos no tocante ao consumo mercantil. A relação entre determinados tipos de relação de troca e a estrutura sensória humana já havia sido abordada por alguns autores clássicos. A nosso ver, esse era o foco de Simmel (1987) ao tratar da vida mental da metrópole, quando apontou para a relação entre um estilo de vida marcado pelas condições fragmentadas da grande cidade industrial e o que ele chama de "atitude blasé", essa postura emocional dessensibilizada - o que não exclui a ideia da conformação das capacidades sensoriais em determinada direção concreta, direção esta por ora menos sensível aos estímulos externos. É importante ressaltar que, no texto de 1902, era a própria relação entre as mudanças sociais e as mudanças sensoriais que estava sendo colocada de modo enfático por Simmel. 
Paulo. ${ }^{178}$ Já o café, junto com a cerveja e outros produtos atuais, apenas muito recentemente foram disseminados como bens marcadores das elites brasileiras. Não é de se estranhar que a Associação Brasileira de Café e Barista (ACBB), instituição sociologicamente relevante no sentido de apreendermos a consolidação dos serviços relacionados ao café e que dão suporte ao consumo de elite, só veio a surgir em 2005 e, ainda por cima, no intuito de "difundir a utilização dos cafés especiais no mercado interno", segundo informações do site da associação. A partir deste momento, o significado simbólico e marcador social do café só fez crescer, o que se estende da rua ao espaço doméstico, como fica nítido na seguinte fala da diretora da Associação Brasileira de Cafés Especiais (BSCA), Vanúsia Nogueira: “as cafeterias dentro do Brasil estão aumentando muito e a pessoa que toma um café desse começa a buscar bebidas de melhor qualidade até para consumir em casa". ${ }^{179}$ Nesse contexto, alguns colocariam a questão de onde vem a inovação. $\mathrm{Na}$ verdade, a direção do processo, pensado em termos de causalidade unidirecional, é pouco relevante para os nossos propósitos. O que nos interessa observar é que o surgimento de novos produtos, novos sabores, novos agentes, novos valores e novos espaços de consumo, tudo isso emerge simultaneamente como parte de uma nova configuração. Eis, pois, um amálgama de fatores confluentes entre si: agricultura, indústria, serviços, pessoas e objetos.

Como bem sabemos, é possível vincular o boom do mercado gourmet em geral, e do café em especial, às novas estratégias de afirmação e legitimação das classes médias e

178 É preciso dizer que o vinho e o café possuem uma relação maior do que mera analogia. O antropólogo William Roseberry (1996) já havia notado que existe uma transposição do modelo de gestão comercial do vinho para o mundo do café. Por exemplo, já na segunda convenção da associação norte-americana de cafés especiais, a Specialty Coffee Association of America (SCAA), criada em 1982, um grupo de vinícolas e de mercadores do vinho foram chamados para dar palestras e fornecer conselhos aos empresários do café. Sobre essa questão, Roseberry, ao elencar as vantagens que os cafés gourmets oferecem em relação aos café do mercado de massa, diz também que um dos prazeres possibilitados pelo novo produto é a sua inclusão no conjunto de bens voltados para a demonstração e discriminação dos gostos daqueles que o consomem - lógica que ficou conhecida como a função de "distinção social" dos bens de consumo: "Specialty coffees taste better than mass-market coffees. They offer pleasures in many ways: (...) the inclusion of coffee purchasing, preparation, and consumption in a widening spectrum of foods - including wines, beers, waters, breads, cheeses, sauces, and the like - through which one can cultivate and display 'taste' and 'discrimination'." (ROSEBERRY, 1996, pg. 762-763). Com base no que falamos aqui, podemos dizer que o café, assim como outros bens de consumo, a depender da configuração histórica particular da relação entre classes sociais e comida, servem como momentos de exercício da "linguagem do gosto" - uma linguagem que põe em correlação coisas e pessoas, uma linguagem que classifica o mundo dos homens ao classificar o mundo das coisas e vice-versa.

179 Redação Globo Rural. "Consumo e preço impulsionam mercado de cafés especiais". Globo Rural, 19 jul. 2013. 
altas brasileiras. Certamente nos interessa aquilo que Bourdieu define por "distinção social", a capacidade que os consumidores possuem de estilizar suas preferências em matéria de gosto a fim de maximizar as possibilidades de lucro simbólico: o lucro via prestígio. Ainda assim, a função distintiva das escolhas em matéria de gosto, que é diretamente ligada à questão maior da reprodução social das classes em termos do conjunto total do patrimônio, não foi tomada como uma premissa da nossa pesquisa. Ao invés de partirmos de uma leitura mais funcionalista da obra do Bourdieu - que estabelece a priori que "o sistema de gostos e de práticas culturais participa da reprodução das relações de dominação" (COULANGEON, 2004), nós nos atemos à faceta mais "disposicionalista" da obra. ${ }^{180}$ A leitura disposicionalista parte da premissa mais geral de que "recursos posicionais diferentes engendram disposições que se manifestam em diferentes sistemas de prática" (COULANGEON, 2004). Em suma, voltamos ao velho problema materialista das condições de existência informando o modo como os seres humanos compreendem a realidade a sua volta. No nosso caso específico, interessava saber como as condições do serviço nos estabelecimentos especializados em café estavam contribuindo para a manutenção de certos tipos de competência prática. Quanto a isso, o que está sendo observado no mercado gourmet são novos quadros de referência, são novos meios de orientação no espaço social, que envolvem não apenas esquemas de pensamento, mas esquemas práticos, disposições, aptidões e emoções específicas.

Faz-se necessário entender melhor a tese que Bourdieu defende, em especial na sua obra $A$ Distinção (2007), para circunscrever em que medida é possível utilizar alguns de seus conceitos. Partindo de uma perspectiva relacional, o autor defende que existe uma

180 Jon Elster (1981) chama atenção para o caráter tautológico da postura funcionalista bourdieusiana, uma vez que o argumento da reprodução social se explicaria por si próprio, pela repetição do postulado. Para Elster, trata-se do mesmo modo de raciocínio da sociodicéia, isto é, daquelas narrativas teológicas que buscam justificar o sofrimento no mundo apelando aos efeitos secundários. No caso da sociologia, isso ocorre à medida que se enfatiza a funcionalidade das instituições vigentes para a manutenção e o fortalecimento da opressão. Elster desenha a estrutura lógica dessa postura teórica: "A sociodicéia enquanto um dispositivo de legitimação está intimamente associada ao funcionalismo como quadro explicativo. Uma vez que se aceite que certos fenômenos deploráveis têm boas consequências em cadeia, estamos a um passo do argumento de que essas consequências também explicam as causas que as produzem. Logicamente falando, esse argumento não tem validade a menos que também se demonstre o nexo de causalidade entre o efeito e a manutenção da causa, mas poucos autores se dão o trabalho de fazer isso. Sempre houve, e ainda há, um desleixo tremendo na maior parte dos trabalhos sociológicos, que implicitamente assumem que uma instituição social ou um padrão de comportamento é explicado assim que sejam identificadas as suas 'funções latentes'." 
correlação estrutural entre os julgamentos estéticos e as posições no espaço social. Dependendo de onde o sujeito se situa (sua origem social, sua trajetória, sua profissão) é provável que tenha determinados gostos, que consuma determinados produtos, que pratique determinados esportes e assim por diante. A noção de habitus ressalta exatamente esse vínculo, pois é um sistema de disposições interligadas, que só ganham seu sentido completo quando percebidas de acordo com uma posição dada no espaço social, que é o espaço das diferenças de posse em termos de capitais. Bourdieu chega a falar que "o gosto é essa capacidade bizarra de fazer distinções que distinguem". ${ }^{181} \mathrm{Na}$ mesma operação em que se classifica, se é classificado. Por exemplo, alguém diz que uma musica é boa, aí chega outra pessoa e diz que esse sujeito tem "mal gosto". O sujeito classifica as coisas e as coisas o classificam de volta. Todavia, é preciso que exista uma espécie de código ou chave interpretativa para que o processo de julgamento se realize, resultando na hierarquização das pessoas. O "valor" social que o sujeito irá receber, em sua aproximação com as coisas do consumo, vai sempre refletir seu lugar de origem e sua trajetória de vida. No mundo de hoje, é muito mais difícil encontrar o modo de expressão unificado (habitus) de uma classe, até porque as instâncias de socialização se multiplicaram de lá para cá, elas não se reduzem mais à escola e à família. É importante ressaltar que é mais fácil afirmar a homologia entre a classe (posição social) e os gostos/comportamentos em sociedades fortemente marcadas por princípios oriundos da aristocracia, como era o caso da França dos anos 1970. Isso se dá pelo ímpeto de segregação que marca o contexto aristocrático. Há, portanto, alguns agravantes na transposição desse modelo para o nosso estudo de caso. Para que os acionamentos classificatórios do universo do café produzam efeitos de prestígio - isto é, rendimentos simbólicos diferenciais entre aqueles que seguem seus

181 Bourdieu faz essa afirmação numa entrevista com Dominique Bollinger, em 1991, para o CNPD. Mas essa mesma ideia era central à obra de 1979 (2007), A Distinção. No que concerne à relação entre as disposições estéticas propriamente ditas (pintura, música, arte em geral) e as disposições alimentares, a duplicidade da noção de "distinção" foi formulada pelo autor no seguinte trecho: "O duplo sentido do termo "gosto" - que, habitualmente, serve para justificar a ilusão da geração espontânea que tende a produzir esta disposição culta, ao apresentar-se sob as aparências da disposição inata - deve servir, desta vez, para lembrar que o gosto, enquanto "faculdade de julgar valores estéticos de maneira imediata e intuitiva" é indissociável do gosto no sentido de capacidade para discernir os sabores próprios dos alimentos que implica a preferência por alguns deles. (...) De fato, basta abolir a barreira mágica que transforma a cultura legítima em um universo separado para perceber relações inteligíveis entre "escolhas", aparentemente, incomensuráveis - tais como as preferências em matéria de música ou cardápio, de esporte ou política, de literatura ou penteado.” (BOURDIEU, 2007, pg. 95) 
protocolos e aqueles que não os seguem — é necessário que esteja em jogo algum princípio de dominação, algo que expresse imediatamente as posições sociais. Ora, esse princípio não precisa tomar necessariamente a forma de uma oposição entre o gosto puro das classes superiores e o gosto bárbaro das classes baixas, como muitas vezes supõe o modelo bourdieusiano, e que requer o acoplamento histórico de múltiplas instâncias destinadas ao culto da fruição gratuita e livre das urgências práticas: a montagem das instituições da disposição estética "pura". Além do mais, a superioridade do gosto das elites precisa ser reconhecida pelas outras classes para que funcione como um recurso de exclusão e fomente a reprodução social, daí a dualidade estrutural entre a cultura erudita e a cultura popular. Mas será que esse é sempre o caso? Alguns autores caminham em outras direções:

Para os gostos operarem como recursos excludentes, a superioridade dos gostos da elite precisa ser largamente reconhecida através das classes, e as elites precisam defender ativamente essa hierarquia simbólica, Cf. Lamont, 1992. A bem documentada existência de gostos e estilos das classes dominadas que não levam em conta os gostos dominantes - por exemplo, os achados da escola de Birmingham de que a juventude da classe trabalhadora desenvolve subculturas distintivas que valorizam gostos opostos - é oferecida como evidência contrária a essa leitura da teoria bourdieusiana do gosto, Cf. Lamont \& Lareau, 1988. Esses críticos interpretam a teoria bourdieusiana como uma teoria emulacionista do status que é assinalado através de bens consensuais de status [consensus status goods] similares àqueles investigados por Lloyd Warner (assim como Veblen e Simmel). As fronteiras de classe são postas a operar apenas no grau em que os gostos das elites culturais são reconhecidos e respeitados por aquelas classes abaixo. (HOLT, 1997, pg. 95) ${ }^{182}$

A ideia acima é superar as leituras da obra do autor que supõem uma rígida estabilidade nos processos de demarcação do status, por exemplo, mediante a noção de "bens consensuais de status", cujo valor estenderia-se para todo o espectro sociodemográfico. Na mesma linha, os modelos que colocam o status como ponto de

\footnotetext{
182 "For tastes to operate as an exclusionary resource, the superiority of elite tastes must be ackwowledged widely across classes, and elites must actively defend this symbolic hierarchy (Lamont, 1992). The welldocumented existence of tastes and styles of dominated classes that pay no heed to dominant tastes - for example, Birmingham school findings that working class youth often develop distinctive subcultures that valorize oppositional tastes - is offered as evidence countering the plausibility of this reading of BTT (Lamont and Lareau, 1988). These criticisms interpret BTT as an emulationist theory of status signaled through consensus status goods similar to that expounded by Lloyd Warner (as well as Veblen and Simmel). Class boundaries are posited to operate only to the degree that the tastes of cultural elites are recognized and accorded respect by those classes below."
} 
partida e não como resultado das práticas, inspirados na problemática weberiana do processo de rotinização da magia (no sentido literal ou metafórico do termo) e sua progressiva delimitação em esferas especializadas, só conseguem interpretar o surgimento de novas formas de arte e cultura quando as associam ao aparecimento de novas elites. A própria ideia de "elite" pressupõe a existência de posições precisas no espaço social: alguns lugares são automaticamente dotados de necessidades simbólicas de afirmação. ${ }^{183}$ Nós acreditamos que esse pode até ter sido o caso em algumas épocas passadas. Hoje, no entanto, é notável o poder destruidor que o mercado possui sobre as culturas de status, mediante a incessante renovação dos esquemas de gosto e da oferta de bens:

A alta cultura emergiu como uma cultura de status de uma classe em formação; como notou Max Weber (1968), mercados dinâmicos são inerentemente antagonísticos a culturas de status. Os mercados de bens culturais possibilitam que os consumidores convertam riqueza financeira em símbolos de status e levam os produtores a apagar as fronteiras de gênero em busca de maiores audiências. (DIMAGGIO, 1991, pg. 142) ${ }^{184}$

A nosso ver, esse traço dinamogênico do mercado acaba dificultando o trabalho daqueles pesquisadores que procuram construir um quadro total do espaço social, pretensão que em seu cerne porta a ideia da antecipação projetiva das posições sobre os gostos, do espaço social sobre a práticas sociais. Por essa mesma razão, Bourdieu havia apostado no princípio teórico da conversibilidade entre diferentes tipos de capitais. $\mathrm{O}$ autor francês já sabia que, na prática, as sociedades ocidentais contemporâneas haviam borrado as fronteiras rígidas entre a arte pura e as atividades mais ordinárias, como os gastos em comida e esporte. Nesse sentido, a existência daquele domínio espiritual, apartado das outras dimensões vitais, cessou de ser razão suficiente para justificar a existência de uma determinada estrutura objetiva de distribuição. ${ }^{185} \mathrm{O}$ objetivo do livro $A$ Distinção era reconstruir a conexão entre os diferentes níveis da prática, juntando os gostos em matéria

${ }^{183}$ Em termos mais abstratos, trata-se da questão da legitimidade e do poder simbólico de impor uma classificação de mundo.

184 "High culture emerged as a status culture of a class in formation; as Max Weber (1968) noted, dynamic markets are inherently antagonistic to status cultures. Markets for cultural goods enable consumers to convert financial wealth into symbols of status and drive producers to efface genre boundaries in search of larger audiences."

185 Em outras palavras, a existência de um domínio isolado do sagrado não é mais suficiente para justificar a presença da desigualdade e do sofrimento no mundo. A sociodicéia precisa de novas bases. 
de música, de pintura, de comida, de esporte, de escolha política, e assim por diante - na tentativa de montar uma topografia total dos gostos da sociedade francesa da década de 1970, descobrindo as proximidades e os distanciamentos entre as diferentes unidades significativas. ${ }^{186}$ Como estratégia, Pierre Bourdieu optou por fazer uma sociologia dos estilos de vida, já que a noção de estilo de vida poderia cumprir a função de mediação que faltava para compreender a conexão entre o espaço das posições (definidas, em grande medida, pela distribuição das ocupações profissionais e suas respectivas possibilidades de capitalização econômica e escolar) e o espaço concreto das práticas, ou seja, a distribuição do tempo/dinheiro da população em diferentes categorias de consumo.

Podemos dizer que o resultado teórico proposto n'A Distinção é, em última instância, uma sociologia do conhecimento articulada em três dimensões. Em primeiro lugar, temos o espaço social (distribuição das ocupações e dos respectivos recursos vinculados às ocupações). Em segundo lugar, o espaço dos estilos de vida, o mecanismo hereditário da cultura, que funciona apenas na ordem informal e inconsciente, como eixo intermediário (mediativo) entre o espaço virtual das posições e a concretude das práticas e gastos de consumo. Por último, temos o espaço das práticas, no qual só a etnografia é capaz de captar as nuanças. Na época em que foi formulado, a verdadeira inovação do modelo criado residia na instância analítica intermediária, a centralidade da noção de gosto (habitus, disposição, inclinação, esquema perceptivo, apreciativo, padrão de gosto) como ponte de inteligibilidade entre a posição social (sempre em estado de trânsito, portanto, em potencial) e a certeza prática mobilizada no ato mercantil. Lembrando que mediação não é mera intermediação, logo, os esquemas de gosto podem cumprir seu papel de ponte de forma eficaz ou ineficaz - a depender do confronto entre as estratégias, as condições de competição e as consequências não calculadas do jogo. Como cerne da investigação, estava essa dimensão dos estilos de vida que é o que Bourdieu buscava ao tentar fazer um mapeamento dos habitus justapostos naquela configuração histórica. Para realizar tal empreitada, Bourdieu tinha acesso a um enorme manancial de dados estatísticos, a partir do qual poderia se estabelecer uma comparação entre a frequência dos gostos e as

\footnotetext{
186 Nesse ponto, o projeto bourdieusiano possui algumas conexões com o que a semiótica francesa estava procurando fazer naquele período. Cf. BARTHES, 1961.
} 
ocupações profissionais. ${ }^{187}$

O problema dos estilos de vida remete diretamente à questão da classificação simbólica. Trata-se do problema da escritura, para falar nos termos de Jacques Derrida. Como se realiza o agrupamento hierárquico dos bens (culturais ou não) em tipos e gêneros distintos? Como se dá a transposição estratégica do desigual para o diferente, já que todo bem ou prática isoladamente considerado não significa nada, portanto, precisa ser ativamente integrado dentro de um sistema de relações sígnicas para fazer sentido. Esses problemas todos dizem respeito ao enxugamento da polissemia das associações sígnicas encontradas por aí (objetos, práticas, pessoas) em categorias do entendimento humano salto que, ao mesmo tempo, cumpre a função de marcação simbólica/legitimação/ sacralização da estrutura de poder. Barthes fala o seguinte, usando o exemplo da alimentação:

Desde que uma necessidade é sustentada pelas normas de produção e de consumo, assim que ela passa para o nível da instituição, não podemos mais dissociar a função do signo da função; isso é verdadeiro para a vestimenta; é também verdadeiro para a comida; ela é, sem dúvida, a primeira necessidade do ponto de vista antropológico (que é, de qualquer maneira, absolutamente abstrato); mas desde quando o homem não se alimenta mais de frutos selvagens, essa necessidade é fortemente estruturada: substâncias, técnicas, usos, todos eles entram dentro de um sistema de diferenças significativas, e a partir daí a comunicação alimentar é fundada. (BARTHES, 1961, pg. 980) ${ }^{188}$

Nós não estamos aqui preocupados com a criação de um campo semântico apartado, tal como é o caso da comida para Barthes. ${ }^{189}$ Apenas nos interessa a ideia, presente tanto nele como em Bourdieu, de que as coisas não significam nada por si só. Elas

${ }^{187}$ No Brasil, nós não possuímos nada parecido que possibilite tamanha orquestração sistemática dos dados empíricos da cesta de consumo. Há algumas tentativas (BERTONCELO, 2013), mas elas envolvem apenas a quantificação do engajamento em práticas culturais (cinema, teatro, leitura, restaurantes, jornais), deixando de lado a questão qualitativa dos modos de apreciação dessas práticas (o problema do gosto) e a questão do montante de conhecimento codificado e manipulado nessas "escolhas" de consumo.

188 “'Car dès qu'un besoin est pris en charge par des normes de production et de consommation, bref dès qu'il passe au rang d'institution, on ne peut plus dissocier en lui la fonction du signe de la fonction; c'est vrai pour le vêtement; c'est aussi vrai pour la nourriture; elle est sans doute, d'un point de vue anthropologique (d'ailleurs parfaitement abstrait), le premier des besoins; mais depuis que l'homme ne se nourrit plus de baies sauvages, ce besoin a toujours été fortement structuré: substances, techniques, usages entrent les uns et les autres dans un système de différences significatives, et dès lors la communication alimentaire est fondée."

189 Barthes utiliza a mesma definição de estrutura dos autores da linguística: estrutura como "uma entidade autônoma de dependências internas". 
precisam ser mediadas por alguma instância interpretativa. No modelo de Barthes, essa instância é o sistema dos signos. Por exemplo, através dessa noção podemos dizer que o consumo de açúcar não é apenas o consumo da substância açúcar, mas envolve todo um universo de práticas nas quais, lá onde a ausência do álcool se traduz numa proliferação de bebidas açucaradas, o consumo assume a forma do repouso, da viagem, do "viver o dia", da ociosidade, ou seja, um conjunto de protocolos de uso que, juntos, transformam o açúcar numa verdadeira categoria de mundo para os norte-americanos (BARTHES, 1961, pg. 978). Nessa mesma direção, Barthes estende a reflexão para todo o espectro da comida:

Comer é um ato de conduta que se desenvolve para além do seu próprio fim, que substitui, resume ou sinaliza outras condutas, e é por essa razão que é um signo. Quais condutas? Hoje é possível dizer: todas; a atividade, o trabalho, o esporte, o esforço, o lazer, a festa, cada uma dessas situações tem a sua expressão alimentar; e nós podemos até mesmo dizer que essa "polissemia" da alimentação caracteriza a modernidade. (...) O snack [lanche] não responde apenas a uma nova necessidade, ele dá a essa necessidade uma certa expressão teatral, ele constitui aqueles que o consomem em homens modernos, ou seja, em administradores dotados de poder e controle sobre a velocidade intensa da vida contemporânea. (BARTHES, 1961, pg. 985) ${ }^{190}$

No modelo que mais nos interessa, o modelo de Pierre Bourdieu, essa instância mediativa é o próprio corpo humano e não o sistema de signos (definido por temas gerais e situações de uso). É nesse sentido que o corpo é dotado de uma competência cultural de entender e apreciar adequadamente os objetos. Filosoficamente falando, não existe coisa em si. As coisas só existem nos engajamentos práticos dos corpos que delas se apropriam. Toda competência que relaciona corpos e coisas pressupõe um tempo de aprendizagem, um tempo que é devotado para se aprender como consumir. Quanto maior for esse tempo, mais rara é a competência, portanto, mais autenticidade possui o conhecimento adquirido. Assim, tudo desemboca na questão da acumulação do conhecimento como capital - uma

190 "Se nourrir est une conduite qui se développe au delà de sa propre fin, qui remplace, résume ou signale d'autres conduites, et c'est en cela qu'elle est bien un signe. Quelles conduites? On pourrait dire aujourd'hui: toutes: l'activité, le labeur, le sport, l'effort, le loisir, la fête, chacune de ces situations a son expression alimentaire; et l'on pourrait presque dire que cette sorte de 'polysémie' de la nourriture caractérise la modernité. (...) le snack ne répond pas seulement à un besoin nouveau, il donne à ce besoin une certaine expression théâtrale, constitue ceux qui le fréquentent en hommes modernes, en managers ayant pouvoir et contrôle sur l'extrême rapidité de la vie contemporaine." 
resposta das ciências sociais à disseminação da economia como estilo de pensamento. Esse conhecimento, entretanto, não precisa necessariamente tomar uma forma ideacional racionalizante, tal como prevalece nas teorias da ideologia e nos desdobramentos da noção de representação. Aliás, ele é muito mais eficaz, como ferramenta de dominação, quando não toma a forma ideacional e permanece no domínio informal e inconsciente da intuição: eis a tese de Pierre Bourdieu.

Dito isso, cabem algumas ressalvas em relação àquilo que absorveremos do modelo bourdieusiano. Não partiremos aqui da premissa de que existe uma dicotomia estrutural entre gosto puro e gosto vulgar, apenas acionaremos a maneira do autor resolver o problema da legitimidade das classes em um mundo contemporâneo de suposta grande mobilidade social. Até porque não estamos movidos pelo ímpeto de mapear a totalização do espaço de consumo numa configuração histórica particular. Nossos objetivos e nossos objetos são mais fragmentários que isso, dizem respeito a contextos práticos bastante precisos. Quanto ao problema geral, a questão da legitimidade, para o autor, é transposta para o problema do gosto, que pode ser definido também como o "julgamento das coisas com base em noções de prestígio" (FILHO \& LOPES, 2008). Para os nossos propósitos, investigamos em que medida o processo de gourmetização pode ser entendido como um processo de formação de um tipo específico de gosto ${ }^{191}$, não necessariamente coadunado a nenhuma classe em particular e nem definido pela sua contraposição interna dentro de um sistema total de gostos (que em última instância leva à polarização entre gosto popular e gosto de elite). No entanto, podemos entender o processo de formação do gosto gourmet como fazendo parte do processo mais amplo de substituição do capital econômico pelo capital cultural na produção da escala hierárquica de estilos de vida, seguindo a sugestão weberiana e bourdieusiana:

As preferências estéticas e as práticas culturais estão, nas sociedades ocidentais contemporâneas, dentre os atributos simbólicos que progressivamente suplantam a propriedade e o consumo ostentatório de bens materiais nos rituais de identificação mútua da vida social (Veblen, 1970; Douglas e Isherwood 1979), à medida que o papel do capital cultural vem concorrer com aquele do capital econômico no estabelecimento da

${ }^{191}$ Ou seja, uma instância mediativa e interpretativa das práticas. 
distribuição de status (DiMaggio, 1987). (COULANGEON, 2004, pg. 60) 192

Quanto à natureza precisa dessa noção de cultura, nós não temos respostas ainda. $\mathrm{O}$ que sabemos, pelo andamento da pesquisa, é que ela não toma a forma consagrada dos chamados "bens culturais", isto é, aqueles bens que existem com o propósito de significar outras práticas, como é o caso dos filmes, das músicas, dos livros, dos objetos artísticos, enfim, todos aqueles artefatos que são resultados, de uma maneira ou de outra, da criação autoral e que funcionam como miniaturas de visões de mundo subjetivamente articuladas. Que noção de cultura é posta em jogo no processo de refinamento investigado, que poderíamos chamar de processo civilizador gourmet, mas que não pressupõe o estilo de pensamento abstrato, metafórico e distanciado, característico da cultura humanista e letrada europeia, e sim uma imersão no domínio do sensível?

192 "Les préférences esthétiques et les pratiques culturelles comptent, dans les sociétés occidentales contemporaines, parmi les attributs symboliques qui supplanten progressivement la propriété et la consommation ostentatoire des biens matériels dans les rituels d'indentification réciproque de la vie sociale (Veblen, 1970; Douglas et Isherwood, 1979), à mesure que le rôle du capital culturel vient concurrencer celui du capital économique dans l'établissement des échelles de status (DiMaggio, 1987).” 


\section{CONSIDERAÇÕES FINAIS}

Dos mais de 55 bilhões de dólares faturados por ano na venda de café, apenas 13\% do total permanece nos países exportadores (RUZICH, 2008, pg. 431). Essa disparidade em relação ao valor agregado dos produtos comercializados se deve, em grande parte, à importância que adquiriu, nas duas últimas décadas, a cafeteria como espaço de consumo, local não apenas de venda de produtos, mas de venda das experiências em torno do café. Hoje, sabe-se que a cafeteria é o tipo de loja que mais cresce no setor de restaurantes no mundo. ${ }^{193}$ Do ponto de vista gastronômico, ou seja, em termos do prazer propriamente gustativo do ato de se tomar café, o barista é a figura central no processo. Ele não apenas prepara, mas articula, a nível performático, o ato de degustação sensorial do café, o retorno que o corpo dá aos objetos experimentados. Quanto menor o formato de uma cafeteria, mais intimidade e troca comunicativa existe entre os baristas e os consumidores: o que resulta em maior disseminação de conhecimento. Daí que a terceira onda, a onda mais experimentalista, deposita sua preferência nas cafeterias independentes e locais, em contraste com grandes redes como a Starbucks, em que o processo de mecanização é maior. A tônica passa a ser posta na degustação como um espécie de ajuste espontâneo entre o corpo e o produto experimentado. O interessante é que no momento em que o ato de degustação ganha relevância pública, algumas preferências são elegidas ao mesmo tempo em que a abertura à diversidade sensorial passa a ser defendida por um grande contingente de consumidores. Vimos que os baristas, na atual tendência, possuem preferências que tendem a um perfil de sabor mais ácido/frutado/floral/leve, em contraste com o sabor mais queimado/rústico/amargo/encorpado do café tradicional brasileiro. Alguns baristas defendem que é preciso trabalhar para converter as pessoas para o perfil moderno na medida em que isso diria respeito à "qualidade" do produto. Da maneira como eles entendem, a "qualidade" se expressaria em corpos e cheiros bem definidos, na medida em que esses parâmetros não precisam operar em altos níveis de abstração. Mais ainda, eles dizem que todas as percepções estão imediatamente disponíveis aos consumidores e necessitam apenas de treino para serem ativadas. É isso que Renato Gutierres queria dizer

193 Coffee Statistics Report 2014 Edition. 
quando ressaltou que era preciso criar uma nova "cultura de consumo" de café. Alguns baristas chegam até mesmo a aconselhar como desenvolver essa cultura na prática:

"Se você pudesse dizer uma coisa ao consumidor regular de café, o você diria? Abra sua mente e comece a explorar os sabores naturais do café. Muitas pessoas têm uma percepção única do sabor que o café deve ter, mas o café é uma bebida tão diversa. Existem milhares de diferentes cultivos e processos que influenciam no sabor, o que é interessante de se explorar. Compre um moedor de rebarba [burr grinder], um equipamento de preparo simples e comece a procurar os melhores grãos do seu país, assim você vai descobrir alguns sabores realmente interessantes. Mas espere pagar mais pelo seu café. Os preços atuais do café comercial não são sustentáveis para a maioria dos agricultores e, se você quiser qualidade, você terá que pagar um pouco mais por isso." (Oslo: Tim Wendleboe, Kinfolk, July 17) $)^{194}$

Vemos, portanto, que o dinheiro é uma condição necessária para o engajamento nesse tipo de prática de abertura sensorial. Por exemplo, o dinheiro torna possível que o consumidor entre em contato sucessivas vezes com tipos específicos de produtos e tipos específicos de lugares de consumo em que a experiência da degustação é valorizada. Hoje em dia, o ato de comer fora de casa é parte fundamental dos gastos de qualquer pessoa que tenha algum excedente pecuniário. Também o interesse pelo aprofundamento do conhecimento daquilo que se consome vem conforme vai se afastando das obrigações materiais do comer só por comer, para se alimentar. Os agentes do mercado pregam que na sucessão de encontros com os produtos do mercado é possível desenvolver o aparato sensório-motor do consumidor. Vimos que 50\% dos respondentes baristas do nosso questionário responderam que o café foi o primeiro alimento que os levaram a explorar a degustação como modo de consumo - enquanto $35 \%$ já tinham sido levados a essa postura por causa de outros alimentos. Assim que atentamos para a prática concreta de degustação dos baristas e dos consumidores, vemos que as questões de "qualidade" podem ser relativizadas. O que existe, na prática, são diferentes formatações do conhecimento sensível, isto é, da capacidade corpórea de perceber e saborear as coisas. Como condição

194 "If you could tell the average coffee drinker one thing, what would it be? Open your mind and start exploring coffee's natural flavors. A lot of people have one perception of what coffee should taste like, but coffee is so diverse. There are thousands of different cultivars and processes that influence the flavor and that is really interesting to explore. Get a burr grinder, a simple brewing device and start sourcing the best beans in your country and you'll discover some really interesting flavors. But expect to pay more for coffee. Current commercial coffee prices are not sustainable for most farmers and if you want quality you have to pay a bit more for it." 
necessária, a capacidade gustativa só se desenvolve a partir de padrões de gosto previamente adquiridos pelos indivíduos, portanto, permanece sempre atrelada aos contextos socio-materiais específicos em que foi formada. A autora Annemarie Mol (2012) já havia nos trazido luz sobre o fato de que qualquer modo de degustação precisa ser construído em contextos específicos e que, como consequência, a postura experimentalista em matéria de comida não pode ser pressuposta em todo consumidor que frequenta estabelecimentos gastronômicos, mesmo quando nos restringimos aos estabelecimentos voltados para segmentos de alto padrão aquisitivo:

"Aqui está o contexto. A comida e a bebida não induzem naturalmente as pessoas à 'degustação' [tasting]. Em muitas circunstâncias, os seres humanos não atentam para o gosto daquilo que estão comendo e bebendo. Existem línguas que contêm apenas quatro ou cinco palavras para especificar os sabores. Se você é um pastor Samburu, que vive do mesmo tipo de leite todos os dias, você não precisa de um vocabulário extenso sobre gosto.” (MOL, 2012, pg. 125)

Ora, a consolidação do ethos gourmet nos dias atuais é a potencialização de uma relação de ecletismo específica com os produtos alimentares, algo próximo do que alguns autores chamaram de "consumo onívoro". Isso ocorre na medida em que o gosto aparece como uma maximização do prazer do indivíduo e as avaliações são estabelecidas de forma relativamente independente dos "gêneros" consagrados da atividade de comer e beber. Ao mesmo, é possível dizer que isso alimenta novas formas de hierarquia simbólica, consolidando as chamadas "gastroelites", que possuem os capitais necessários ao culto do prazer gastronômico e que procuram angariar prestígio através das práticas ligadas à comida. O consumo de café hoje ganha seu sentido enfático a partir dessas novas formas, e o café aparece como elemento de diferenciação social dentro do conjunto dos artefatos culturais que servem à legitimação dos segmentos sociais, sejam eles tradicionais ou em ascensão. Embora os sociólogos já estejam acostumados a tratar a questão da função que o gosto desempenha, ou seja, a ideia do gosto como valor de distinção, eles abordam pouco

195 "Here is the context. Food and drink do not naturally induce people into 'tasting'. Under many circumstances human beings do not particularly attend to the taste of what they are eating and drinking. There are languages that contain only four or five words that specify tastes. But if you are a Samburu pastoralist, by and large living off the same kind of milk from one day to the next, you do not need an extensive taste vocabulary." 
ou quase nada a respeito da formação do gosto em contextos específicos. O gosto aparece regularmente nas análises sociológicas sob a forma de "marcador social" ou de modo de "distinção", o que remonta à discussão de Simmel sobre a moda como um fenômeno social e à discussão de Veblen sobre a função do gasto ostentatório. Poucos são os estudos que procuram dar conta do gosto como uma propriedade compartilhada entre o consumidor e o produto, como uma instância ontológica que reflete todas as transformações sofridas na cadeia de valor de um produto. A nosso ver, essa dimensão é fundamental caso não se queira perder de vista alguns dos conflitos que estão se proliferando nas metrópoles atuais, conflitos que, por sua vez, repercutem nas atribuições de status. Até porque, como vimos na etnografia realizada nas cafeterias de São Paulo e Brasília, o que aciona esse tipo de conflito é o sabor que as coisas portam e não as eleições pessoais tomadas como parte de uma estrutura de ação distanciada da materialidade dos objetos. Nesse sentido, o engate estaria mais do lado do objeto do que do sujeito (COCHOY, 2004). O sujeito responde imediatamente, quase que impulsivamente, aos aspectos físicos e organolépticos do café comprado. Ele reclama. Ele adora. Qualquer que seja a reação, ele sente que os cafés dos baristas provocam uma sensação diferente do "trava-língua forte do cafezinho" com o qual estava acostumado. Essa diferença está associada tanto aos novos métodos utilizados no preparo (Hario V60, Sifão, Aeropress, etc.), quanto aos diferentes perfis de grão que estão sendo propagados na onda artesanal (torra clara, 100\% arábica, data de torra recente, etc.). Em última instância, isso resulta na polarização dos perfis de sabor em dois extremos do domínio sensório: o ácido e o amargo. Vale ressaltar que esses termos não são tomados aqui como categorias do entendimento dos consumidores, mas como parte das características mesmas do objeto. As pessoas podem concordar ou discordar a respeito dessas noções, ou do valor específico que cada noção porta e ainda assim o conflito irá permanecer. Porque o conflito existe em razão das qualidades percebidas no produto, ou melhor, em razão da familiaridade que certos sabores vão despertar na boca do consumidor.

Em uma matéria da $\mathrm{BBC}$, o filósofo David Berman defende que a preferência entre o amargor e a acidez está correlacionada a diferenças psicológicas fundamentais nos 
indivíduos. ${ }^{196}$ A acidez (sour), por possuir características sensoriais "mais complexas, delicadas e sutis", teria como correspondência consumidores ácidos (sourists) dotados de um "paladar nuançado". ${ }^{197}$ Já o amargor (bitter), "mais uniforme e mais fácil de ficar certo", estaria na contrapartida de um consumidor amargo (bitterist) considerado "não sofisticado" pelos especialistas em café. O problema é que, antes de tudo, o filósofo irlandês trata essas preferências como se elas fossem inatas e desconsidera o papel socializador que as cafeterias desempenham na transformação de hábitos arraigados de consumo. Como bem sabemos, a própria flutuação dos hábitos na sociedade de consumo problematiza os imperativos da oposição entre gosto simples e gosto sofisticado. Até porque sabemos que hábito é hábito em qualquer lugar. A estrutura mundana que constrói o gosto pelo café forte e amargo é a mesma que constrói o gosto em outras direções. O que mudam são os arranjos socio-materiais e as qualificações de prestígio atreladas a essas materialidades que vão e vêm no tempo. Nosso estudo procurou realizar um mapeamento das coordenadas do consumo de café hoje no Brasil tendo em vista as consequências da chamada gourmetização dos produtos gastronômicos.

O primeiro ponto que eu gostaria de levantar é que há uma tensão no próprio mercado em relação ao "refinamento" dos produtos em termos da "qualidade" e do teor moral da apreensão dessa “qualidade". O próprio caráter gourmet do café por vezes adquire um caráter aristocrático, por vezes não. No caso do café, cabe notar que o ímpeto segregativo do seu uso social é menor do que outros produtos gourmetizados. Em relação à cozinha e a gastronomia de restaurante, o café persiste como um produto mais banal, sua banalidade permanece evidente a despeito do grau de ritualização que ele vem adquirindo. Isso não impede que alguns conflitos envolvendo a afirmação social via consumo ganhem concretude no espaço das cafeterias, como parte da tendência geral de difusão maciça de bens de consumo como atos de simbolização e de avaliação "sociométrica". Só que o que observamos é que o ato de simbolização presente nas demonstrações cotidianas de conhecimento técnico são indissociáveis da intromissão do hábito como filiação intuitiva das preferências individuais, tópico que nos chama atenção para as adaptações que o corpo

\footnotetext{
196 ROBSON, David. "The philosopher who studies the experience of coffee". BBC, Future, May 18, 2015.

197 HUMPHREYS, Joe. "Is bitter better? The philosopher's coffee quest". The Irish Times, Food \& Drink, June 26, 2015.
} 
humano sofre ao longo do tempo.

Mesmo que exista uma lógica reflexiva do consumo, baseada na incorporação de uma disposição para o consumo muito bem informada, é importante acrescentar que a atração involuntária por produtos específicos exerce seu papel definidor nos contextos de tomada de decisão mercantil. Essa atração é resultado da força dos hábitos e não da emergência de atores reflexivos (TEIL \& HENNION, 2004). Nosso intento na pesquisa era explorar o vínculo entre a consolidação mais ampla do gosto gourmet e as práticas de socialização pelo mercado que, a nosso ver, operam nesse nível inconsciente. Nesse quesito, vimos que o barista está situado numa posição privilegiada, pois é ele quem detém o arsenal técnico e especializado que pode vir a ser transmitido para o consumidor sob a forma de uma competência prática. Se isso constitui um caminho para o "esclarecimento gustativo" ou não, essa questão não entra no âmbito da nossa pesquisa. Nós vimos que as transformações materiais do café, ou seja, os processos que atingem a composição físicoquímica do produto e de sua embalagem, desempenham uma parte significativa no movimento de cristalização das preferências atuais. Por outro lado, também as transformações da ordem do gosto (pensado como instância subjetiva) possuem um papel significativo, na medida em que a disposição e as habilidades do barista, a atmosfera criada pelas cafeterias, as formas de comercialização e os rituais de consumo, enfim, todas as facetas do tratamento dos produtos pelo setor de serviços agem em confluência. Defendo que para se entender os modos que a desigualdade toma no mundo contemporâneo, após a pulverização das instâncias de legitimação, é preciso levar em conta esses dois planos de interferência. Ora, a etnografia conduzida no bojo do curso de formação de baristas jogou luz sobre essa articulação entre a dimensão do objeto e a dimensão do sujeito da degustação. No Coffee Lab, muitas vezes os produtos funcionavam de forma similar ao efeito de "choque" do cinema para o Walter Benjamin, isto é, como um meio artificial de impulsionar o corpo humano para momentos de reconhecimento. Se o olho humano não entrar em contato com as emissões luminosas frenéticas do cinema, nada será desenvolvido enquanto capacidade adaptativa visual. $\mathrm{Na}$ perspectiva benjaminiana, a recepção pelo "choque" se dá em meio à experiência generalizada da "distração" cotidiana, logo, ele é um meio de atravessar a apatia que caracteriza a vida mental metropolitana. Aos poucos, 
Benjamin pensa que uma nova cultura se edifica a partir da oscilação entre a distração e o choque: uma cultura marcada pelo aguçamento do "senso de realidade, uma sensibilidade à crônica, ao documento, ao detalhe" (HANSEN, 2012). A nosso ver, se transpuséssemos os elementos, o diagnóstico também se aplicaria perfeitamente ao processo de gourmetização dos produtos gastronômicos. Atentar para o caráter simultaneamente simbólico e material desse processo adaptativo é fundamental para entender os modos que a desigualdade toma no mundo contemporâneo.

De acordo com Flandrin, vimos que a gastronomia emergiu historicamente como uma "ciência do comer bem", o que se deu em perfeito alinhamento com a postura dos segmentos aristocráticos e burgueses europeus que procuravam se destacar pela estetização dos estilos de vida, pela busca de prazeres mais delicados e pelo refinamento das maneiras em geral. Primeiramente, tal processo de diferenciação começou no interior das antigas famílias aristocráticas em rivalidade direta aos burgueses enriquecidos. Em oposição ao fausto dos novos ricos, foi defendida a simplicidade e a modéstia dos verdadeiros fidalgos. Isso nos leva novamente à função do gosto no jogo social. Contudo, a própria ideia de "refinamento" no âmbito da gastronomia pressupõe uma novidade inédita na mecânica da distinção social, a saber, a preocupação em sentir o gosto verdadeiro das coisas e não ornamentos artificiais (FLANDRIN, 1998a). Inevitavelmente, o aprofundamento na dimensão objetual do prazer de comer, ao galgar espaço no mundo, acaba ricocheteando nas perspectivas que pressupõem a clássica distinção entre "sujeito" e "objeto". Alguns intérpretes reclamam que a simples conversão de uma gama de objetos ao princípio da gastronomia é nociva em termos do ataque que ela exerce sobre a definição mais clássica de cultura. É essa a posição do crítico literário William Deresiewicz, que publicou um artigo no The New York Times com o título "Uma questão de gosto?”:

Mas o que aconteceu não é que o alimento foi levado à arte, mas que ele a substituiu. A apreciação de comida [foodism] assumiu características sociológicas do que costumava ser conhecido (...) como cultura. Ela é cara. Ela exige um conhecimento especializado, o que é caro de se desenvolver. Ela funciona como emblema de pertencimento às classes superiores, um exemplo perfeito daquilo que Thorstein Veblen, o grande crítico social da Era Dourada, chamou de consumo conspícuo. Ela é um veículo para a aspiração de status e para a competição, uma ocasião sempre oportuna para demonstrações de esnobismo, de superioridade pessoal e de agressão social. (Meu mercado de fazendeiros tem tomates maiores, melhores e mais frescos 
do que o seu.) Ninguém se importa mais se você entende de Mozart ou Leonardo, é melhor que você saiba discutir a diferença entre o ganache e a couverture. (...) Assim como o esteticismo, a religião da arte, herdou a posição do cristianismo entre as classes progressistas na virada do século 20, a apreciação de comida [foodism] tomou o lugar do esteticismo na virada do século 21. Agora lemos o evangelho de acordo, não com Joyce ou Proust, mas com Michael Pollan e Alice Waters. (...) Aqui na América estamos em perigo de confundir os nossos paladares com as nossas almas. (DERESIEWICZ, William. "A Matter of Taste?". The New York Times, Sunday Review: Opinion, Oct 26, 2012) ${ }^{198}$

A fala acima vem como uma espécie de lamentação acerca da emergência da esfera gastronômica na temática da definição das novas identidades culturais e do prestígio atrelado a essas novas identidades. De uns tempos para cá, o conhecimento gastronômico se transformou em um tipo de capital. Sua eficácia enquanto código de conduta generalizado depende de uma complexa rede de atores e de seus suportes materiais e institucionais, envolvendo regimes científicos, profissionais e vocacionais do saber especializado. Em última instância, a dispersão caracteriza o modo de definição dos perfís de produto e dos critérios de apreciação dos produtos qualificados como gastronômicos: revistas sobre comida, relatórios médicos, livros de cozinha, jornais, programas de televisão, blogs, degustadores profissionais, técnicas artesanais, padrões industriais de larga-escala, e assim por diante, todos esses elementos funcionam como elos na cadeia maior do conhecimento gastronômico. Nas últimas décadas, o café também entrou na lógica especializante dessa cozinha gastronômica, incorporando e potencializando a organização do prazer vinculado ao ato de preparar e de comer. Nosso trabalho se baseou na etnografia realizada no contexto de mercado do café e procurou ver em que medida esse contexto está fomentando novos tipos de capital. O intento era olhar o mundo a partir daquele artefato: a história do café como um artefato cotidiano. Claro que aquilo que

198 "But what has happened is not that food has led to art, but that it has replaced it. Foodism has taken on the sociological characteristics of what used to be known (...) as culture. It is costly. It requires knowledge and connoisseurship, which are themselves costly to develop. It is a badge of membership in the higher classes, an ideal example of what Thorstein Veblen, the great social critic of the Gilded Age, called conspicuous consumption. It is a vehicle of status aspiration and competition, an ever-present occasion for snobbery, one-upmanship and social aggression. (My farmers' market has bigger, better, fresher tomatoes than yours.) Nobody cares if you know about Mozart or Leonardo anymore, but you had better be able to discuss the difference between ganache and couverture. (...) Just as aestheticism, the religion of art, inherited the position of Christianity among the progressive classes around the turn of the 20th century, so has foodism taken over from aestheticism around the turn of the 21st. Now we read the gospel according, not to Joyce or Proust, but to Michael Pollan and Alice Waters. (...) Here in America, we are in danger of confusing our palates with our souls." 
chamamos, no capítulo três, de novo tipo de capital (o capital sensório, o capital gastronômico ou a degustação como modo de apreensão dos objetos, que também constitui forma de capitalização de recursos) é algo muito pequeno, se compararmos ao capital econômico, cultural, simbólico ou social, pensados em termos amplos. Mas constitui um caso pertinente, especialmente se levarmos em conta que bebemos 2,25 bilhões xícaras de café por dia no mundo. O caso também faz sentido quando compreendemos o momento em que estamos no mercado de cafés: na agricultura, na indústria e nos serviços. Não é novidade dizer que o consumo pode se manifestar enquanto produção de grupos sociais. A contribuição particular que o presente trabalho pode trazer a esse debate diz respeito ao tratamento analítico dos sabores do café como parte das estratégias de diferenciação que compõem o jogo social, o que se realiza também em consonância com a consolidação da profissão barista no mercado de trabalho. Os corpos que entram em contato com o novo aparato simbólico e material dos serviços de café se destacam dos corpos que mantém a tradição: a partir daí, novas fronteiras simbólicas são erigidas e performatizadas pelos consumidores. Só que as mesmas "fronteiras simbólicas" dependem de maneira visceral dos momentos de reconhecimento concreto: momentos em que o corpo é levado a experimentar os produtos e a julgar as diferenças entre A e B a partir da experiência efetivada. Ao invés de pensarmos em termos de oposições abstratas de classificação, à maneira dos estruturalistas, nós precisamos apreender essas distinções na feição em que elas adquirem na prática concreta. É exatamente isso que se propõe Barthes, ao defender que precisamos submeter os fatos coletados "à prova da comutação", isto é, observar se a passagem de um fato a outro produz um efeito significativo. No nosso caso de pesquisa, ao passarmos do cafezinho forte e amargo ao café de perfil mais ácido próprio das novas cafeterias, não só observamos uma diferença de natureza significativa, mas presenciamos conflitos de ordem interativa, baseados naquela distinção e envolvendo relações de desgosto/antipatia entre os consumidores e os funcionários dos estabelecimentos. $\mathrm{O}$ amargor e a acidez aparecem aqui como relances dos agenciamentos e dos processos mais amplos que tornam esses agenciamentos possíveis. No texto sobre a psicosociologia da alimentação, Barthes (1961) chega a citar um survey de Paul Lazarsfeld realizado em 1934 que já trabalhava com o detalhamento dos sabores em sua relação com as diferentes classes 
sociais:

Uma investigação de P. F. Lazarsfeld (ela é velha, particular e eu a cito a título de exemplo) mostrou que alguns 'gostos' sensoriais podem variar de acordo com a renda dos grupos sociais interrogados: as pessoas de baixa renda adoram chocolates doces, tecidos lisos, perfumes fortes; as classes superiores, ao contrário, preferem substâncias amargas, tecidos irregulares e perfumes leves. Para ficarmos no plano da alimentação, é evidente que a significação (que remete a um duplo significado social: classes superiores, classes médias) não apreende os gêneros de produtos, mas apenas os sabores: é o doce e o amargo que entram em oposição significativa, é nesse nível que temos de circunscrever algumas unidades do sistema alimentar. (BARTHES, 1961, pg. 981) ${ }^{199}$

Colocações como essa são importantes para nos ajudar a entender a maneira em que a experiência sensória estrutura a vida cotidiana em seu caráter imediato, posto que o corpo é a fonte primária da nossa relação com o mundo. ${ }^{200}$ Se entendermos o conceito de capital enquanto "labor humano acumulado", algo que pode potencialmente produzir diferentes formas de lucro, torna-se justificável a presente tentativa de estender o princípio para os mínimos detalhes da nossa vida social, tal como o ato de se tomar café. A partir dessa formulação, podemos ser levados a observar, por exemplo, como a circulação internacional de sabores é a expressão da maneira como estão sendo distribuídos uma série de recursos na economia global. Isso não é tudo. O que está em jogo, em última instância, é como todos esses processos reverberam no senso que as pessoas possuem de si ao agirem no mundo. E nesse âmbito, é possível dizer que a percepção final da desigualdade resultante da circulação dos produtos econômicos dependerá, sempre e necessariamente, dos arranjos simultaneamente simbólicos e materiais disponíveis. Daí que, na nossa perspectiva, o status seja tomado não como uma motivação originária das condutas humanas, mas como um resultado circunstancial dos usos dos produtos e das qualidades que são perceptíveis para o consumidor, afinal, são elas que tornam possível a ratificação do melhor e do pior.

199 “Une enquête de P. F. Lazarsfeld (elle est ancienne, particulière et je ne la cite qu'à titre d'exemple) a montré que certains 'goûts' sensoriels pouvaient varier selon le revenu des groupes sociaux interogés: les personnes à revenu faible [de renda baixa] aiment les chocolats doux, les tissus lisses, les parfums forts; les classes supérieures, au contraire, préférent les substance amère, les tissus irréguliers et les parfums légers. Pour en rester sur le plan d'alimentation, on voit bien que la signification (qui renvoie elle-même à un double signifié social: classes supérieurs, classes moyennes) ne saisit nullement des espèces de produits, mais seulement des saveurs: ce sont le doux et l'amer qui entrent en opposition signifiante, c'est donc à ce niveau qu'il faut situer certaines unités du systéme alimentaire."

200 A esse respeito, Bourdieu (2007) chega a dizer que "o corpo é a mais incontestável materialização dos gostos de classe". 
Os corpos são acoplados aos espaços e aos objetos de sua atuação em um mundo socialmente disponível. Se levarmos essas questões em conta, poderemos nos aproximar do espaço social por outro ângulo e, como consequência, a desigualdade social pode ser posta à prova e ser vista em seu caráter mundano e contextual. Acreditamos que as transformações organizacionais (mercadológicas) têm implicações duradouras sobre a maneira como os corpos estão sendo socializados nas sociedades contemporâneas. O gosto gourmet é um dos resultados dessa transformação estrutural. Junto com a família e a escola, o mercado também pode ser tomado pela sociologia como uma instância socializadora, na medida em que ele também contribui para definir pautas e prioridades de socialização. Focando na proliferação dos chamados produtos gourmets, nós intentamos construir aqui um retrato, por vezes fragmentário, daquilo que podemos chamar de pedagogia do mercado, isto é, a forma como o mercado contribui para socializar os indivíduos, seja definindo competências, seja qualificando a raridade dessas mesmas competências. O café aparece como elemento dessa trama, não mais reduzido a suas antigas funções, ou seja, como propulsor energético em razão da cafeína, como elemento de sociabilidade ou como simples prazer associado à tradição e ao amargor da bebida escura. Talvez não seja demais dizer que tomar café hoje se tornou uma espécie de encruzilhada, afinal, qual é mesmo o tipo de café que você gosta? 


\section{REFERÊNCIAS BIBLIOGRÁFICAS*}

ANDREUCCI, Cecília \& POMPEU, Bruno. "Nespresso, a Busca da Felicidade Privada: auratização do produto e ritualização do consumo". In: Perez \& Trindade (org.) II PróPesq - Encontro Nacional de Pesquisadores em Publicidade e Propaganda. São Paulo: 2011.

APPADURAI, Arjun. "Introduction: commodities and the politics of value". In: A. Appadurai (ed.) The social life of things: commodities in cultural perspective. Cambridge: Cambridge University Press, 1986.

ARIÈS, Philippe. “A história das mentalidades" (1978). In: Nova história em perspectiva: volume 1. São Paulo: Cosac Naify, 2011.

BARBOSA, Lívia. "Feijão com arroz e arroz com feijão: o brasil no prato dos brasileiros". Horizontes Antropológicos, Porto Alegre, ano 13, n. 28, p. 87-116, 2007.

BARBOSA, Lívia; CAMPBELL, Colin (orgs). Cultura, consumo e identidade. Rio de Janeiro: Editora FGV, 2007.

BARTHES, Roland. "Pour une psycho-sociologie de l'alimentation contemporaine". In: Annales: Économies, Sociétés, Civilisations. 16e année, nº 5, 1961.

BEHR, Edward. The Artful Eater: A Gourmet Investigates the Ingredients of Great Food. New York: Atlantic Monthly Press, 1992.

BELASCO, Warren. "Food Matters: perspectives on an emerging field". In: Warren Belasco and Philip Scranton (Eds.) Food Nations: selling taste in consumer societies. New York: Routledge, 2002.

BENJAMIN, Walter. "Paris do Segundo Império". In: Obras Escolhidas III: Charles Baudelaire um lírico no auge do capitalismo. São Paulo: Brasiliense, 1989.

BENJAMIN, Walter. "A doutrina das semelhanças". "Sobre o conceito da história". In: Obras Escolhidas I: Magia e Técnica, Arte e Política. São Paulo: Brasiliense, 2012.

BENJAMIN, Walter. A obra de arte na era da reprodutibilidade técnica. Porto Alegre: Editora Zouk, 2012b.

BERTONCELO, Edison Ricardo Emiliano. "Classes e práticas sociais". Revista Brasileira de Ciências Sociais, Vol. 28, nº 81, 2013.

\footnotetext{
* Essa seção lista primeiramente os textos estritamente acadêmicos. Mais adiante, constam duas outras seções de referência: artigos de jornal e revista e outros conteúdos virtuais.
} 
BLUMER, Herbert. "Fashion: From class diferentiation to collective selection". In: The Sociological Quarterly, Vol. 10, 1969.

BOLZ, Norbert. "Onde encontrar a diferença entre uma obra de arte e uma mercadoria?". In: Revista USP, n. 15, 1992.

BOLZ, Norbert. "Sinn-Designer - On the management of cultural meaningfulness". In: "What Makes Sense?": Cultural Management and the Question of Values in a Shifting Landscape. Dresden: ENCATC, 2005.

BOURDIEU, Pierre. "Ethos, habitus, hexis". In: Questions de Sociologie; extrait de "Le marché linguistique”, comunicação na Universidade de Genebra, dezembro, 1978.

BOURDIEU, Pierre. "The Historical Genesis of a Pure Aesthetic". In: The Journal of Aesthetics and Art Criticism, Vol. 46, Analytic Aesthetics, 1987.

BOURDIEU, Pierre. Razões Práticas: Sobre a teoria da ação, Campinas, Papirus Editora, 1996.

BOURDIEU, Pierre. El baile de los solteros: la crisis de la sociedad campesina en el Bearne. Barcelona: Editorial Anagrama, 2004.

BOURDIEU, Pierre. A distinção: crítica social do julgamento. São Paulo: Edusp; Porto Alegre, RS: Zouk, 2007.

BOURDIEU, Pierre. A economia das trocas linguísticas: o que falar quer dizer. São Paulo: Edusp, 2008.

BOURDIEU, Pierre \& DELSAUT, Madame Yvette. "Pour une Sociologie de la perception". In: Actes de la recherche em sciences sociales, Vol. 40, Sociologie de l'oeil, 1981.

BOURDIEU, Pierre \& WACQUANT, Loic. "Symbolic capital and social classes". In: Journal of Classical Sociology, 13(2), 292-302, 2013.

CALLON, Michel \& MUNIESA, Fabian. "Les marchés économiques comme dispositifs collectifs de calcul”. In: Réseaux. No. 122, pg. 189-233, 2003.

CALLON, Michel; MÉADEL, Cécile \& RABEHARISOA, Vololona. "The economy of qualities". In: Economy and Society. 31:2, 194-217, 2002.

CHARTIER, Roger. "Formas de privatização". In: História da Alimentação. São Paulo: Estação Liberdade, 1998. 
COCHOY, Franck. "Por uma sociologia da embalagem". Antropolítica, Niterói, n. 17, p. 69-96, 2004.

COLLAÇO, Janine Helfst Leicht. "Um olhar antropológico sobre o hábito de comer fora". In: Campos: Revista de Antropologia Social, 2003.

COULANGEON, Philippe. "Classe sociales, pratiques culturelles et styles de vie: le modèle de la distinction est-il (vraiment) obsolète?". In: Sociologie et sociétés, Vol. 36, N. $1,2004$.

DIMAGGIO, Paul. "Social structure, institutions, and cultural goods: the case of the United States". In: Pierre Bourdieu and James S. Coleman (eds.) Social Theory for a Changing Society. New York: Russell Sage Foundation, 1991.

DURKHEIM, Émile. As formas elementares da vida religiosa: o sistema totêmico na Austrália. São Paulo: Martins Fontes, 1996.

ELIAS, Norbert. O processo civilizador: uma história dos costumes. Vol. 1, Rio de Janeiro: Zahar, 2011.

ELSTER, Jon. “Snobs”. In: London Review of Books, Vol. 3, No. 20, 1981.

FABIANI, Jean-Louis. “Peut-on encore parler de légitimité culturelle?”. In: O. Donnat and P. Tolila (eds.) Le(s) Public(s) de la culture: Politiques publiques et équipements culturels. Paris: Presse de Sciences Po, 2003.

FARIAS, Edson. Práticas Culturais nos Fluxos e Redes da Sociedade de Consumidores. Brasília: Verbis, 2010.

FARIAS, Edson. "O que pode a triangulação entre dinheiro, expressões culturais e esfera pública nos dizer sobre a diversidade e universalidade?”. IN: CASTRO, Ana Lúcia (org.): Cultura Contemporânea, Identidades e Sociabilidades: olhares sobre corpo, mídia e novas tecnologias. São Paulo: Cultura Acadêmica, 2010.

FARIAS, Edson \& MIRA, Maria Celeste (org.). Faces Contemporâneas da Cultura Popular. Jundaí: Paco Editorial, 2014.

FEATHERSTONE, Mike. Cultura de consumo e pós-modernismo. São Paulo: Studio Nobel, 1995.

FEATHERSTONE, Mike. “A vida heróica e a vida cotidiana”. In: O desmanche da cultura. São Paulo: Studio Nobel, 1997.

FILHO, Clóvis de Barros; LOPES, Felipe Tavares Paes. A dominação pelo gosto: o 
consumo na sociologia de Bourdieu. In: BACCEGA, Maria Aparecida (Org.). Comunicação e culturas do consumo. São Paulo: Atlas, 2008.

FISCHLER, Claude. “A 'McDonaldização' dos costumes”. In: História da Alimentação. São Paulo: Estação Liberdade, 1998.

FLANDRIN, Jean-Louis. "A distinção pelo gosto". In: História da Vida Privada - da renascença ao século das luzes. São Paulo: Cia das Letras, 1991.

FLANDRIN, Jean-Louis. "Le goût a son histoire". In: F. Piault (ed.) Le Mangeur: Menus, Maux et Mots. Paris: Autrement, Coll. Mutations/Mangeurs No 138, 1993.

FLANDRIN, Jean-Louis \& PHAN, Marie-Claude. "La beauté, le désir \& le goût: essai d'analyse historique du corps”. In: Revista História, São Paulo, n. 127-128, 1993.

FLANDRIN, Jean-Louis. "Da dietética à gastronomia, ou a libertação da gula". In: História da Alimentação. São Paulo: Estação Liberdade, 1998a.

FLANDRIN, Jean-Louis. "Tempero, cozinha e dietética nos séculos XIV, XV e XVI". In: História da Alimentação. São Paulo: Estação Liberdade, 1998b.

FLANDRIN, Jean-Louis. “Os tempos modernos". In: História da Alimentação. São Paulo: Estação Liberdade, 1998c.

FLANDRIN, Jean-Louis \& MONTANARI, Massimo. "Conclusão: hoje e amanhã". In: História da Alimentação. São Paulo: Estação Liberdade, 1998.

FREEMAN, James; FREEMAN, Caitlin; DUGGAN, Tara. The Blue Bottle Craft of Coffee: Growing, Roasting, and Drinking, with Recipes. Berkeley: Ten Speed Press, 2012.

GAGNEBIN, Jeanne Marie. "De uma estética da visibilidade a uma estética da tatibilidade em W. Benjamin”. In: Walter Benjamin: Formas de percepção estética na modernidade. Salvador: Quarteto Editora, 2008.

GARCIA, Rosa Wanda Diez. "Práticas e comportamento alimentar no meio urbano: um estudo no centro da cidade de São Paulo". Cadernos de Saúde Pública, 13(3), Rio de Janeiro, 1997.

GARCIA, Rosa Wanda Diez. "Reflexos da globalização na cultura alimentar: considerações sobre as mudanças na alimentação urbana". Revista de Nutrição, Campinas, 16 (4), 2003.

GARCIA-PARPET, M. F. "Mundialização dos mercados e padrões de produção: vinho, o modelo francês em questão". Tempo Social, São Paulo, v. 16, n. 2, 2004. 
GARTMAN, David. "Culture as class symbolization or mass reification? A critique of Bourdieu's Distinction”. In: American Journal of Sociology, Vol. 97, No. 2, 1991.

GINZBURG, Carlo. "Sinais: raízes de um paradigma indiciário". In: Mitos, Emblemas, Sinais. 2a Edição. São Paulo: Companhia das Letras, 2011.

GRONOW, Jukka. "Taste and Fashion: the social function of fashion and style". In: Acta Sociologica, Vol. 36, No. 2, 1993.

GUMBRECHT, Hans Ulrich. Produção da presença: o que o sentido não consegue transmitir. Rio de Janeiro: Contraponto: Ed. PUC-Rio, 2010.

GUTHMAN, Julie. "Fast food/organic food: reflexive tastes and the making of yuppie chow”. In: Social \& Cultural Geography, Vol. 4, No. 1, 2003.

HANSEN, Miriam. "Benjamin, cinema e experiência: a flor azul na terra da tecnologia". In: Tadeu Capistrano (org.) Benjamin e a obra de arte: técnica, imagem, percepção. Rio de Janeiro: Contraponto, 2012.

HEATH, Deborah \& MENELEY, Anne. "Techne, Technoscience, and the Circulation of Comestible Commodities: an Introduction”. In: American Anthropologist, Vol. 109, Issue 4, 2007.

HOLT, Douglas B. "Distinction in America? Recovering Bourdieu's theory of taste from its critics". In: Poetics, Vol. 25, 1997.

HORIZONTES ANTROPOLÓGICOS, Porto Alegre, ano 13, n. 28, “Antropologia e Consumo", 2007.

HOWES, David. "Hyperesthesia, or, the sensual logic of late capitalism". In: David Howes (ed.) Empire of the Senses, Oxford: Berg, 2004.

HOWES, David. "The Social Life of the Senses". Ars Vivendi Journal, No. 3, 4-23, 2013.

ILLY, Andrea \& VIANI, Rinantonio (eds.) Espresso Coffee: the science of quality. London: Elsevier Academic Press, 2005.

JANTZEN, C., FITCHETT, J., ØSTERGAARD, P. And VETNER, M. “Just for fun? The emotional regime of experiential consumption" In: Marketing Theory, 12(2), 137-154, 2012.

JOHNSTON, Josée \& BAUMANN, Shyon. Foodies: democracy and distinction in the gourmet foodscape. New York: Routledge, 2015. 
KAUFMAN, Robert. “Aura, still”. In: Andrew Benjamin (Ed.) Walter Benjamin and Art. London: Continuum, 2005.

KON, Anita. "Sobre as Atividades de Serviços: Revendo Conceitos e Tipologias". Revista de Economia Política, vol. 19, nº 2 (74), abril-junho, 1999.

KON, Anita. "Sobre a economia política do desenvolvimento e a contribuição dos serviços". In: Revista de Economia Política, vol. 27, no 1 (105), pp. 130-146, janeiromarço, 2007.

KORSMEYER, Carolyn. "Taste, food and the limits of pleasure". In: R. Schusterman and A. Tomlin (eds.) Aesthetic Experience. London and New York: Routledge, 2008.

KUEHN, Glenn. "How Can Food Be Art?”. In: A. Light \& J. Smith (eds.), The Aesthetics of Everyday Life. New York: Columbia University Press, 2005.

LAHIRE, Bernard. "Indivíduo e mistura de gêneros: dissonâncias culturais e distinção de si”. In: DADOS - Revista de Ciências Sociais, Vol. 50, n. 4, 2007.

LAURIER, Eric. "Field Report 1: the basics of becoming a barista" In: The Cappuccino Community: cafés and civic life in the contemporary city. ESRC Project 2002-2004. University of Glasgow, Department of Geography and Topographic Science. 2003.

LE GOFF, Jacques. “As Mentalidades: uma história antiga” (1974). In: História: novos objetos. Rio de Janeiro: Francisco Alves Editora, 1995.

LEIRIS, Michel. "The Sacred in Everyday Life". In: D. Hollier (ed.) The College of Sociology (1937-39). Minneapolis: University of Minnesota Press, 1988.

LEITÃO, Débora Krische; LIMA, Diana Nogueira de Oliveira; PINHEIRO MACHADO, Rosana (Org.). Antropologia e consumo: diálogos entre Brasil e Argentina. Porto Alegre: Age, 2006.

LEMPS, Alain Huetz de. "As bebidas coloniais e a rápida expansão do açúcar". In: História da Alimentação. São Paulo: Estação Liberdade, 1998.

LEVENSTEIN, Harvey A. "Dietética contra gastronomia: tradições culinárias, santidade e saúde nos modelos de vida americanos". In: História da Alimentação. São Paulo: Estação Liberdade, 1998.

LÉVI-STRAUSS, Claude. O totemismo hoje. Lisboa: Edições 70, 1986.

LIMA, Diana N. O. "Ethos 'emergente': as pessoas, as palavras e as coisas". Horizontes 
antropológicos, vol. 13, $\mathrm{n}^{\mathrm{o}}$ 28, Porto Alegre, 2007

LUTTINGER, Nina \& DICUM, Gregory. The Coffee Book: anatomy of an industry from crop to the last drop. The New Press, 2006.

MANN, Anna. "Which context matters? Tasting in everyday life practices and social science theories". Food, Culture \& Society: An International Journal of Multidisciplinary Research, 18(3), 2015.

MANN, A.; MOL, Annemarie; et. al. "Mixing Methods, tasting fingers: notes on an ethnographic experiment". HAU: Journal of Ethnographic Theory, 1 (1), 2011.

MANNING, Paul. "Barista rants about stupid customers at Starbucks: What imaginary conversations can teach us about real ones". Language \& Communication, 28, 101-126, 2008 .

MANZO, John. "Coffee, Connoisseurship, and an Ethnomethodologically-Informed Sociology of Taste”. Human Studies, 33, 141-155, 2010.

MATHIEU, Paula. "Economic Citizenship and the Rethoric of Gourmet Coffee". Rethoric Review, Vol. 18, No. 1, 1999.

MATZLER, Kurt et al. "Business model innovation: coffee triumphs for Nespresso". Journal of Business Strategy, Vol. 34, No. 2, 2013.

MÉADEL, Cécile \& RABEHARISOA, Vololona. "Taste as a form of adjustment between food and consumers". In: (org.) Technology and the market: demands, users and innovation. Londres: Edward Elgar, 2001.

MENNELL, Stephen. "On the Civilizing of Appetite". Theory, Culture \& Society, Vol. 4, 1987.

MERLEAU-PONTY, Maurice. Conversas - 1948. São Paulo: Martins Fontes, 2004.

MINTZ, Sidney. "Food and eating: some persisting questions". In: Warren Belasco and Philip Scranton (Eds.) Food Nations: selling taste in consumer societies. New York: Routledge, 2002.

MOL, Annemarie. "Layers or Versions? Human Bodies and the Love of Bitterness". In: B. Turner (ed.), The Routledge Handbook of Body Studies, 2012.

MOL, Annemarie. "Política Ontológica: algumas ideias e várias perguntas". In: Nunes \& Roque (org.) Objectos impuros: experiências em estudos sociais da ciência. Porto: Edições Afrontamento, 2007. 
MONTERO, Paula. "Questões para a etnografia numa sociedade mundial". Novos Estudos CEBRAP, N. ' 36, Julho, 1993.

MORRIS, Jonathan. "La globalizzazione dell'espresso italiano". Memoria e Ricerca, 23, 2006.

NEIBURG, Federico. "Os sentidos sociais da economia". In: Horizontes das Ciências Sociais no Brasil - Antropologia. ANPOCS/Barcarolla/Discurso Editorial, 2010.

ORTIZ, Renato. Mundialização e cultura. São Paulo: Brasiliense, 2000.

PASSERON, Jean-Claude. "Figuras e contestações da cultura". In: O Raciocínio Sociológico: o espaço não-popperiano do raciocínio natural. Petrópolis: Vozes, 1995.

PETERSON, Richard \& KERN, Roger. "Changing highbrow taste: from snob to omnivore". American Sociological Review, Vol. 61, No. 5, 1996.

PITTE, Jean-Robert. "Nascimento e expansão dos restaurantes". In: História da Alimentação. São Paulo: Estação Liberdade, 1998.

PRIMO, Elizabeth. "Nespresso's strategy: an idea of exclusiveness and personal touch". SciWatch Journal: International Journal of Competitive Intelligence, Strategic, Scientific and Technology Watch, Vol. 5, Issue 3, December, 2012.

PULICI, Carolina. "O gosto dominante como gosto tradicional: preferências e aversões estéticas das classes altas de São Paulo". In: Novos estudos CEBRAP, no.91, São Paulo, 2011.

ROSEBERRY, William. "The Rise of Yuppie Coffees and the Reimagination of Class in the United States”. American Anthropologist, New Series, Vol. 98, No. 4, 1996.

RUZICH, Constance M. "For the Love of Joe: The Language of Starbucks". The Journal of Popular Culture, Vol. 41, No. 3, 2008.

RUFINONI, Priscila Rossinetti. "Modernidade e autonomia da arte". In: Aissa Afonso Guimarães (Org.) Filosofia da Arte. Vitória: UFES, Núcleo de Educação Aberta e a Distância, 2011.

SILVA E MEIRELLES, Dimária. "O Conceito de Serviço". In: Revista de Economia Política, vol. 26, no 1 (101), pg. 119-136 janeiro-março, 2006.

SCHNAPP, Jeffrey T. "The romance of caffeine and aluminum". In: Critical Inquiry, Vol. 28, No. 1, Things, Autumn, 2001. 
SHAPIN, Steven. “The sciences of subjectivity”. Social Studies of Science, 42, 2012.

SHAPIN, Steven. "A mudança nos gostos: que gosto as coisas tinham no começo da era moderna e que gosto têm agora”. In: Novos Estudos CEBRAP, n. 95, 2013.

SIMMEL, Georg. "A metrópole e a vida mental". In: VELHO, Otávio G. (Org.). $O$ fenômeno urbano. Rio de Janeiro: Guanabara, 4a. ed., 1987.

SIMMEL, Georg. “As grandes cidades e a vida do espírito”. Mana, 11 (2), 2005.

SIMMEL, Georg. Filosofia da moda e outros escritos. Lisboa: Edições Texto \& Grafia, 2008.

SIMMEL, Georg. "Sociology of the Senses: Visual Interaction". In: R. Park (ed.) Introduction to the Science of Sociology, 1921.

SOUZA, Jessé. "Em defesa da sociologia: o economicismo e a invisibilidade das classes sociais”. In: Revista Brasileira de Sociologia, Vol. 1, No. 1, 2013.

STANDAGE, Tom. História do mundo em 6 copos. Rio de Janeiro: Zahar, 2005.

SUTTON, David E. "Food and the senses". Annual Review of Anthropology, Vol. 39, 2010.

TAUSSIG, Michael. "History as commodity: in some recent american (anthropological) literature". In: Critique of Anthropology, 1989.

TAUSSIG, Michael. "Tactility and Distraction". Cultural Anthropology, Vol. 6, No. 2, May, 1991.

TAUSSIG, Michael. "Why the Nervous System?". In: The Nervous System. New York: Routledge, 1992.

TEIL, G. \& HENNION, A. "Discovering quality or performing taste? A sociology of the amateur". In: M. Harvey et al. (eds.), Qualities of Food. Manchester and New York: Manchester University Press, 2004.

TEXEIRA, Lucas de Vasconcelos. "Consumo de memórias e experiências na cafeteria paulistana Coffee Lab". Trabalho apresentado no Grupo de Trabalho Comunicação, consumo e memória: cenas culturais e midiáticas, do $4^{\circ}$ Encontro de GTs - COMUNICON, realizado em outubro, 2014.

THOMPSON, Craig J. \& ARSEL, Zeynep. "The Starbucks Brandscape and Consumers' (Anticorporate) Experiences of Glocalization”. In: Journal of Consumer Research, Vol. 31, No. 3, Dezembro, 2004. 
TOPIK, Steven. "Coffee as a social drug". Cultural Critique, No. 71, Drugs in Motion: Mind- and Body-Altering Substances in the World's Cultural Economy, Winter, pp. 81-106, 2009.

TOPIK, Steven. "Coffee". The Cambridge World History of Food. Eds. Kenneth Kiple and Kriemhild Conee Ornelas. New York: Cambridge University Press, 641-52, 2012.

WAGNER, Roy. "Existem grupos sociais nas terras altas da Nova Guiné?". Cadernos de campo, n. 19, 2010.

WACQUANT, Loïc. "Symbolic power and group-making: On Pierre Bourdieu's reframing of class". In: Journal of Classical Sociology, 0(0), 2013.

WEBER, Max. "Rejeições religiosas do mundo e suas direções". In: Ensaios de Sociologia. Rio de Janeiro: Ed. Guanabara, 1982.

WEBER, Max. "Classe, estamento, partido". In: Ensaios de Sociologia. Rio de Janeiro: Zahar, 1982b.

WELSCH, Wolfgang. "Aesthetics Beyond Aesthetics: towards a new form of the discipline”. In: Undoing Aesthetics. London: Sage, 1997.

WILEY, Andrea S. "Transforming Milk in a Global Economy". American Anthropologist, Volume 109, Issue 4, December, 2007.

WOORTMANN, Klaas. "O sentido simbólico das práticas alimentares". In: ARAÚJO, W. M.C.; TENSER, C.M.R. (Org.). Gastronomia: cortes \& recortes. Brasília: Senac, 2006.

WOUTERS, Cas. "Formalization and Informalization: changing tension balances in civilizing processes". Theory, Culture \& Society, 3 (2), 1986.

YACCOUB, Hilaine. "A chamada 'nova classe média': cultura material, inclusão e distinção social” Horizontes antropológicos, vol.17, no. 36, Porto Alegre, 2011. 


\section{OUTRAS REFERÊNCIAS}

\section{Artigos de jornal e revista:}

ALEMÃO, Marcio. “Gourmetizou, dançou”. Carta Capital, 19 jul. 2014.

ALTMAN, Mara. “The Messiah Hails From Portland”. New York Magazine, April, 2009.

AMORIM, Diego. "Alto poder aquisitivo dos brasilienses atrai comércio especializado em café”. Correio Brasiliense, 24 out. 2011.

BARBOSA, Miguel. “A APEX e a promoção do café brasileiro”. Revista do Café, 2012.

CARMICHAEL, Todd. "The End of Stumptown, America's Hippest Coffee Brand". Esquire, May 312011.

CHAPOLA, Ricardo. “Crônica gourmet”. Estadão, Vida \& Estilo, 29 maio 2014.

DERESIEWICZ, William. “A Matter of Taste?”. The New York Times, Sunday Review: Opinion, Oct 26, 2012.

FELITTI, Chico. "Hamburguerias viram hit em SP e número de casas gourmet cresce 500\%”. Folha de São Paulo, 14/ set. 2014.

FONAROW, Wendy. "Ask the indie professor: Is food the new indie rock?". The Guardian, February 18, 2011.

GOLD, Jonathan. "La Mill: The Latest Buzz”. LA Weekly, March 122008.

HUMPHREYS, Joe. "Is bitter better? The philosopher's coffee quest". The Irish Times, Food \& Drink, June 26, 2015.

ILLY, Ernesto. “The Complexity of Coffee”. Scientific American, June, 2002.

KOPSCHITZ, Isabel \& OLIVEIRA, FILIPE. "Produtos gourmet chegam até a comida de cachorro, mas podem desaparecer mais rápido". Folha de São Paulo, 27 jul. 2014.

LUPINACCI, Heloisa. “O microlote é um caminho irreversível”. Estadão, Paladar, 13 dez. 2012.

MADUREIRA, Daniele. "Cresce disputa pelo espresso caseiro". Valor Econômico, Empresas, 30 out. 2012.

MARQUES, Daniel Telles. “Aqui tem café no bule”. Estadão, Paladar, 17 out. 2012. 
MARQUES, Daniel Telles. “Questão de pressão”. Estadão, Paladar, 06 fev. 2013.

MARSHALL, Carolyn. "Alfred H. Peet, 87, Dies; Leader of a Coffee Revolution”. New York Times, September 32007.

MIRAGAIA, Marília \& FREIRE, Bel. "Conheça o passo a passo de diferentes métodos caseiros de fazer café". Folha de São Paulo, Comida, 04 jun. 2014.

MURANO, Edgard. "Sufixos à venda". Revista Língua, Outubro, 2014.

ORENSTEIN, José. “\#gourmet”. Estadão, 29 ago. 2013.

ORENSTEIN, José. “Torrar ou não torrar?”. Estadão, Paladar, 26 fev. 2014.

ORENSTEIN, José. "Michel Bras: 'Não gosto do termo gastronomia'”. Estadão, Paladar, 05 nov. 2014.

PACHECO, Paula. “Todos querem ser um Nespresso". Estadão, E\&N, 19 jul. 2010.

PEDROSO, Paulo. “Cafeterias novas apostam em grãos torrados sob encomenda". Folha de São Paulo, Comida, 06 mar. 2015.

PERALVA, Carla. "Como fazer um bom café em casa". Estadão, Paladar, 14 abr. 2015.

Redação EmbalagemMarca. "O gigante vai acordar?". Revista EmbalagemMarca, Ano XIV, No 169, Setembro, 2013.

Redação Estadão. “E no princípio era apenas o pano”. Estadão, Paladar, 17 out. 2012.

Redação Estadão. "Vivemos a terceira onda do café”. Estadão, Paladar, 3 jul. 2014.

Redação Estadão. “50 coisas que podem ficar em 2014”. Estadão, Paladar, 30 dez. 2014.

Redação Estadão. “Colhido no supermercado”. Estadão, Paladar, 29 jan. 2015.

Redação Folha de São Paulo. "Com perda de patentes, Nespresso perde espaço para concorrentes". Folha de São Paulo, Mercado, 01 jan. 2014.

Redação Folha de São Paulo. "Café”. Folha de São Paulo, Informe Publicitário, 17 de nov. 2014.

Redação Super Interessante. “O que é barista?”. Revista Super Interessante, Edição 196, jan. 2004. 
SANAPO, Francesco. “A próxima geração do café italiano". Revista Espresso, no 38, ano 9, 2013.

Special Report: Luxury. The Economist, December 132014.

TONON, Rafael. 'Vivemos a terceira onda do café'. Estadão, Paladar, 23 jul. 2014.

TONON, Rafael. “A moda gourmet”, Vida Simples, Fevereiro, 2015.

VIEIRA, Willian.“É o rótulo, estúpido!”. Carta Capital, 03 ago. 2014.

\section{Outros conteúdos virtuais:*}

A Film About Coffee. [filme] Direção: Brandon Loper. Avocados \& Coconuts, 2014. Red Epic, $67 \mathrm{~min}$.

BOWMAN, Bobbi. "Starbucks as Demographic Indicator". The Maynard Institute, September 10, 2008.

CHO, Nicholas. "The BGA and the Third Wave", CoffeeGeek, April 12005.

Conferência “L'espresso italiano" [youtube], James Hoffman. World of Coffee, 2014.

Coffee Statistics Report 2014 Edition. Disponível em: <http://coffee-statistics.com/>. Acesso em: 24 ago. 2015.

GIULIANO, Peter. "Giving people what they want". The Specialty Coffee Chronicle, December 112014.

Jornal da Globo. "Faltam profissionais baristas no mercado". Rio de Janeiro: Rede Gobo, 16 out. 2012. Programa de TV.

NETO, Ensei. “Como Preparar A Mais Fantástica Xícara de Café - 1”. Blog The Coffee Traveler, 11 abr. 2012. Disponível em: <http://coffeetraveler.net/como-preparar-a-maisfantastica-xicara-de-cafe-1/>. Acesso em: 24 ago. 2015.

Notícias BSCA. "BSCA inicia uma nova história para os cafés especiais do Brasil". Publicada em 16 de Abril de 2015. Disponível em: <http://bsca.com.br/noticias.php>. Acesso em: 25 maio 2015.

Pesquisa Nielsen. “Café ABIC”. ENCAFÉ, 2013.

* Essa seção lista os textos e os vídeos acessados online. 
PIZARRO, Mariana. "Estudo mostra como as gravadoras sobrevivem na era da internet". [internet] UnBCiência, 17 jun. 2011. Disponível em: <http://www.fe.unb.br/ catedraunescoead/areas/menu/publicacoes/artigos-sobre-tics-na-educacao/estudo-mostracomo-gravadoras-sobrevivem-na-era-da-internet>. Acesso em: 25 ago. 2015.

Podcast. "René Redzepi”. Food is the new rock, Zach Brooks, Ep. 74, December 17, 2013.

PRINCE, Mark. "So what the heck is wrong”. CoffeeGeek, February 06, 2005.

Redação BeanScene. "Hario rides the third wave". BeanScene Magazine, June, 2013.

Redação Correio Brasiliense. "Produtores de cacau experimentam chocolate pela primeira vez na vida". Correio Brasiliense. 15 set. 2014.

Redação Globo Rural. "Consumo e preço impulsionam mercado de cafés especiais". Globo Rural, 19 jul. 2013.

Redação Institute of Food Technologists. "Food scientists working to diminish, mask bitter tastes in foods". Institute of Food Technologists, June 242014.

Redação Midiamax. "Mais saboroso, consumo de café gourmet cresce 5 vezes mais ao ano no país do que tradicional". Publicado em 24 jun. 2014. Disponível em: $<$ http:// www.midiamax.com.br/noticias/915697-mais-saboroso-consumo-de-cafe-gourmetcresce-5-vezes-mais-ao-ano-no-pais-do-que-tradicional.html>. Acesso: 24 ago. 2015.

ROBSON, David. "The philosopher who studies the experience of coffee". $B B C$, Future, May 18, 2015.

ROCHE, Marco de la. "Entrevista com a barista Isabela Raposeiras". Mixology News, 23 jan. 2013.

SAMPSON, Mark T. "Battling bitter coffee -- chemists vs. main source of coffee bitterness". American Chemical Society, August 212007.

Site da Abic. Disponível em: <http://www.abic.com.br>. Acesso em: 25 maio 2015.

Site da ACBB. Acesso em: <http://www.acbb.com.br>. Disponível em: 24 ago. 2015.

Site do Coffee Lab. Disponível em: <http://coffeelab.com.br>. Acesso em: 24 ago 2015.

Site da Counter Culture Coffee. Disponível em: $<$ https://counterculturecoffee.com/contact/ about-us>. Acesso em: 07 maio 2015.

Site da Quartz. Disponível em: <http://qz.com>. Acesso: 21 maio 2015. 
Site do Mark Café. Disponível em: <http://www.markcafe.com.br>. Acesso em: 24 ago 2015 .

Site da Revista Adega. Disponível em: http://revistaadega.uol.com.br. Acesso em: 25 maio 2015.

Site da SNA (Sociedade Nacional de Agricultura). Disponível em: $<\mathrm{http} / / /$ sna.agr.br/ruybarreto-filho-“e-preciso-exportar-cafe-com-valor-agregado"/>. Acesso em: 24 ago 2015.

SKEIE, Trish R. "Norway and Coffee”. The Flamekeeper, Spring 2003.

SNA News. "Rui Bragueta Filho: É preciso exportar café com valor agregado". Publicada em 02 jul. 2012.

VASCONCELOS, Mônica. "Streaming é a luz no fim do túnel para a indústria fonográfica mundial?”. [internet] BBC Brasil, 09 maio 2013.

Wikimedia Commons. Disponível em: <https://commons.wikimedia.org/>. Acesso em: 18 de Setembro 2015.

WENDELBOE, Tim. "The Future of the World Barista Championship". CoffeeGeek, May $1,2006$. 